\title{
AROMÁS VEGYÜLETEK VIZSGÁLATA HÉVIZEKBEN ÉS KELETKEZÉSÜK KÍSÉRLETI MODELLEZÉSE
}

\author{
Doktori értekezés \\ Készítette: \\ Fekete József \\ Témavezetö: \\ Hetényi Magdolna \\ az MTA rendes tagja \\ Konzulens: \\ Sajgó Csanád \\ a földtudomány kandidátusa \\ MTA Csillagászati és Földtudományi Kutatóközpont \\ Földtani és Geokémiai Intézet
}

Környezettudományi Doktori Iskola

Ásványtani, Geokémiai és Kőzettani Tanszék

Szegedi Tudományegyetem, Természettudományi és Informatikai Kar

2013

Szeged 


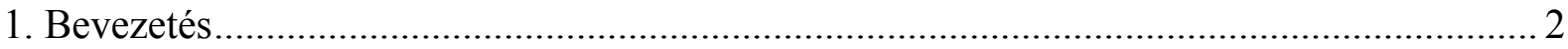

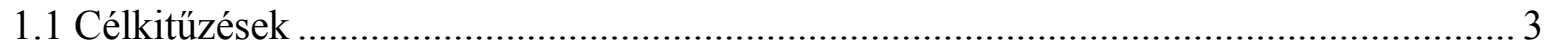

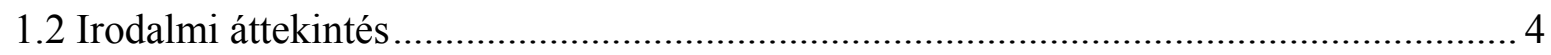

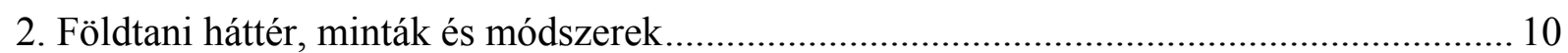

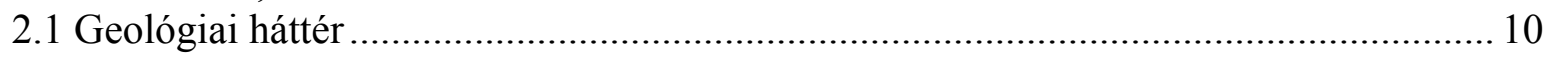

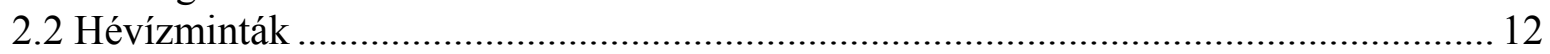

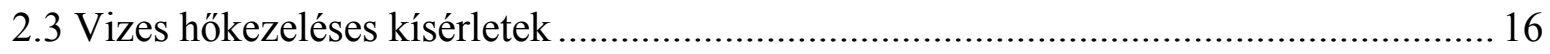

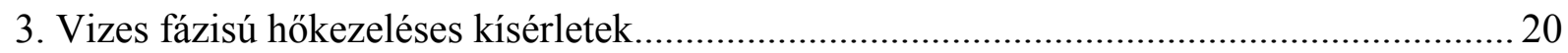

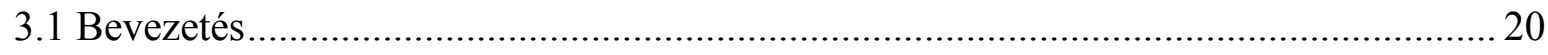

3.2 Felmérő kísérletek, oxidatív körülmények között................................................. 21

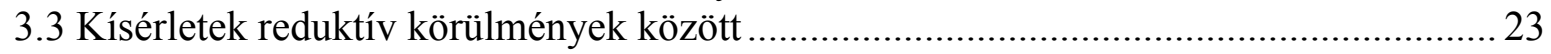

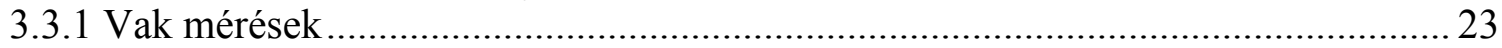

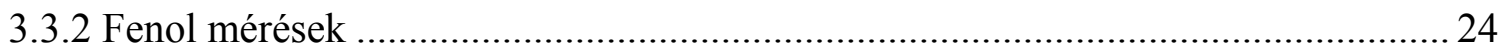

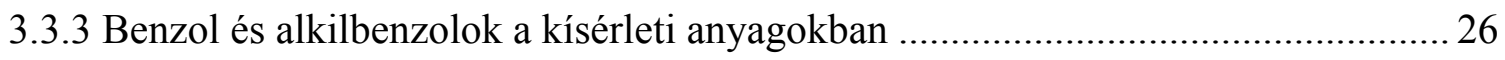

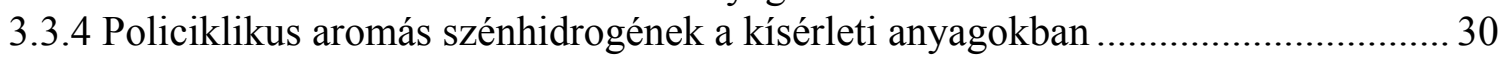

3.3.5 Heteroaromás vegyületek a kísérleti anyagokban ............................................. 33

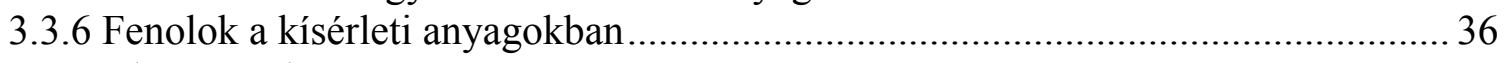

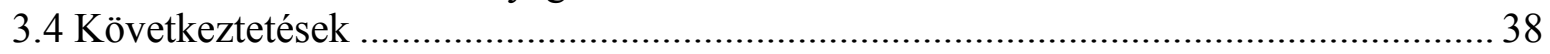

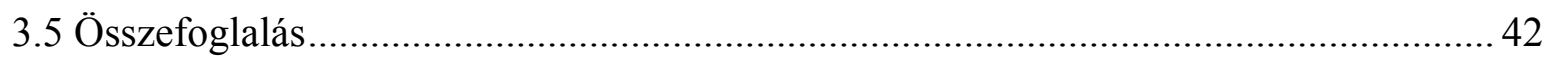

4. Összefüggés a hévizek hőmérséklete, szerves anyagának bomlása és szervetlen összetevői

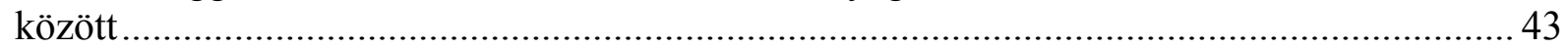

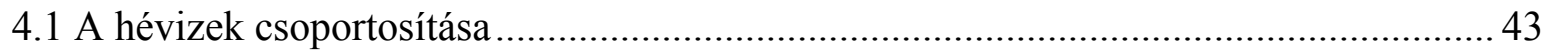

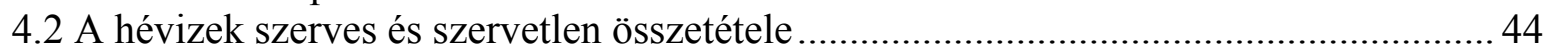

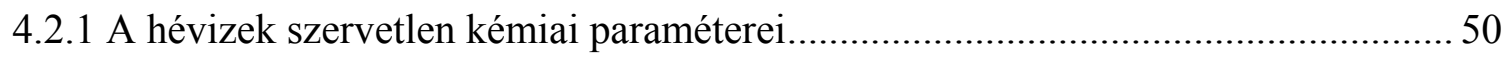

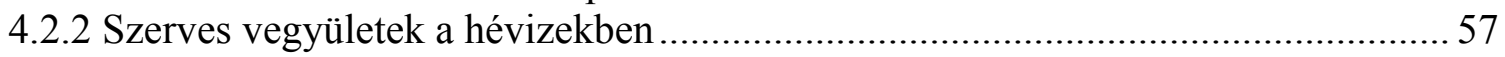

4.3 A hévizekben és a kísérletekben mért szerves vegyületek összehasonlítása ................. 62

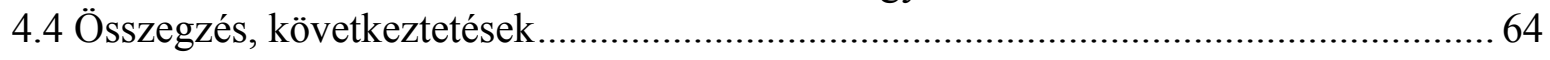

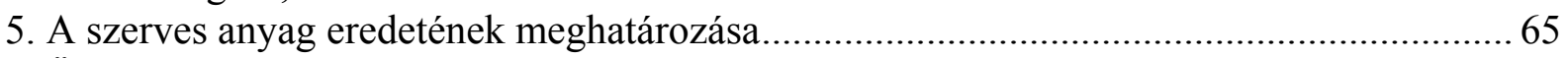

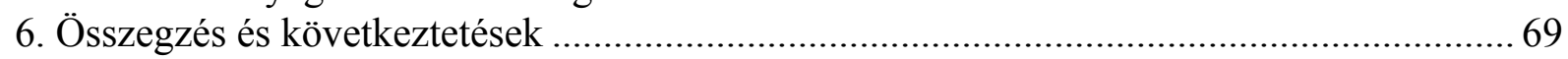

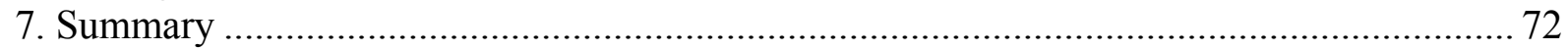

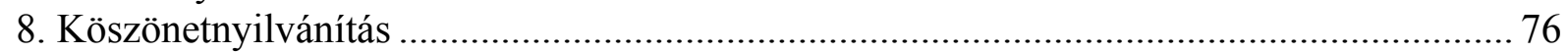

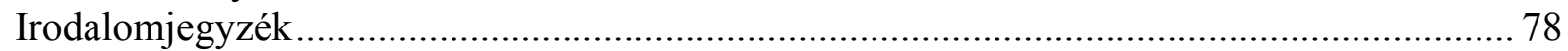

Függelék: a hévizekben és a kísérletekben mért szerves vegyületek koncentrációi ................ 88 


\section{Bevezetés}

A Pannon-medence mélységi vizei jelentős mennyiségben tartalmazhatnak oldott szerves anyagokat. A több mint tizenöt éve, a Johan Béla Országos Közegészségügyi Intézetben (OKI) megkezdett kutatások - amelyekhez később a Magyar Tudományos Akadémia Geokémiai Kutatóintézete (MTA GKKI) és a Magyar Állami Földtani Intézet (MÁFI) is csatlakozott - során vizsgált több száz víz közel felében mutattak ki illékony, mono-, di- és poliaromás szerves vegyületeket (pl. Kárpáti és Klopp, 1994a, b; Kárpáti, 1999; Kárpáti et al., 1999).

Ezen vegyületek között vannak mérgező és/vagy rákkeltő hatású anyagok (pl. benzol, fenolok, poliaromás szénhidrogének), illetve a használt kezelési technológiáktól függően klórfenolok, klórozott dibenzofuránok és bifenilek, és egyéb klórozott szénhidrogének is keletkezhetnek belölük (Johnsen et al, 1989; Kárpáti et al. 1995, 1996a, b, c; 1999; Varsányi et al. 2002). Ezek sokszor nehezen vagy természetes úton nem lebomló, súlyosan mérgező vegyületek. Mivel a hévizeket a balneológiai célú felhasználás mellett Magyarország bizonyos területein ivóvízhez is keverik (nagy arzéntartalmú ivóvíz esetén), ezen szerves vegyületek egészségügyi kockázatot is jelenthetnek. Eredetük és viselkedésük ismerete épp ezért rendkívül fontos annak ellenére, hogy a jelenlegi jogszabályok szerint csak bizonyos szerves összetevők vizsgálata kötelező (pl. benzol).

Az oldott szerves anyagok jelenléte a hévizekben az egészségügyi kockázatok mellett a geotermális energia felhasználása során is problémát jelent. Mivel a szerves vegyületek egy része jellemzően nagy molekulákból álló, főleg humin anyag, molekulaméretük nagymértékben függ a víz tulajdonságaitól: hőmérséklet, nyomás, redox viszonyok, egyéb oldott anyagok jelenléte stb. A geotermikus visszasajtoló kutakban kicsapódó vagy koaguláló szerves anyagok a szürőket és a kőzetpórusokat eltömítve a visszasajtolás hatékonyságát ronthatják.

A fentebb sorolt okok miatt fontosnak és célszerünek tartom a hévizekben oldott szerves anyagok vizsgálatát még akkor is, ha elfogadjuk, hogy a vizekben lejátszódó szerves és szervetlen kémiai reakciók, a különféle korú és összetételü vizek keveredése, valamint a Pannon-medencében helyenként uralkodó nagy hőmérséklet hatása megnehezíti az összefüggések megállapítását, és a párhuzamosan lejátszódó folyamatok súlyozása is csak becsülhető. 
Értekezésem témája része egy OTKA (nyt szám: T 48829) kutatásnak: „A magyarországi termálvíz kincs szervesgeokémiai jellemzése: termálvíz kerogén/bitumen kölcsönhatás geokémiai kutatása", amely döntő részben munkahelyemen folyt (Sajgó, 2010), és ennek keretében végeztem kutatásaimat.

\subsection{Célkitüzések}

Értekezésemben kitűzött célok az alábbiak:

1) Bemutatom, hogy a vizsgált hévizekben a szerves anyag bomlása, ami a korábbi vizsgálatok (Vető et al., 2004b; Fekete et al., 2009; 2010b) alapján jelentősen befolyásolja a vizek szervetlen kémiai összetételét (hidrogén-karbonát, nátriumtartalom), egyben forrása az oldott aromás szerves vegyületeknek. Ez utóbbi vegyületek egy adott küszöbhőmérséklet felett jelennek meg, és koncentrációjuk nem függ a mért oldott szervesanyag-tartalom nagyságától (TOC), sem a kiindulási szerves anyag eredetétől (szárazföldi - tengeri).

2) Kísérleti körülmények között modellezem a vízben oldódó aromás szerves vegyületek keletkezését. Megvizsgálom, hogy a különféle szerves anyagokból (humin- és fulvosavak, bitumen, lignit és geotermális felhasználás során vízből kivált szerves anyag) jellemzően milyen kromatografálható aromás vegyületek keletkeznek vizes közegben történő hőkezelés hatására.

3) A kísérletekben vizsgált szerves anyagokból keletkezett vegyületek minősége és mennyisége, valamint ezek arányai alapján valószínüsítem a vizsgált hévizek oldott szerves anyagainak eredetét, azaz a keletkezésükért felelős prekurzor szerves anyag típusát. A kísérletek során keletkezett szerves vegyületek vizsgálata alapján jellemzem a vizsgált hévizeket, területi jellegzetességeket (fáciest) keresve, az oldott szerves vegyületek eredetén túl azok érettségének kor, hőmérséklet, illetve mélység függését figyelembe véve.

Hangsúlyozottan nem tekintem célnak a természetben vagy a kísérletek során lejátszódó szerves kémiai reakciók bemutatását. A szakirodalom alapján a kémiailag összetett (aromás és alifás, hidrofil és hidrofób részeket, sokféle funkciós csoportot, heteroatomokat tartalmazó), nagy molekulasúlyú kiindulási anyagok vizes hőkezelése esetében lejátszódó reakciók leírását nem tartom lehetségesnek. Az általában egy modellvegyületen, és gyakran savas (foszforsav, 
hangyasav) vagy agyagásvány katalizátor jelenlétében, vagy szerves oldószerben, az általam alkalmazottól eltérő idő- és hőmérsékleti skálán végzett kísérletek áttekintése alapján a feltételezhetően lejátszódó kémiai reakciókat a kutatásom során vizsgált anyagok lehetséges bomlási és keletkezési folyamatainak megértése, illetve értelmezése céljából gyűjtöttem össze (1.2 fejezet). Ezzel azt kívánom bemutatni, hogy a leírt folyamatoknak van publikált és jól definiált reakciókinetikai alapja.

\subsection{Irodalmi áttekintés}

A felszín alatti vizekben oldott szerves anyag jelentős szerepet játszik a diagenetikus folyamatokban, és így a vizek szervetlen kémiai összetételének kialakításában az alábbi tulajdonságok miatt: 1) befolyásolják a pH-t (és a víz pufferkapacitását), 2) képesek oldatba vinni közönségesen nem oldódó fém vagy egyéb szervetlen (komplexképzés) vagy szerves (nalkánok a humin anyagok hidrofób részein) anyagokat; 3) befolyásolják az oldat redox potenciálját; 4) bakteriális vagy termikus úton dekarboxileződésre hajlamosak, így szénhidrogén gázokat és széndioxidot termelnek, ami a karbonátok és egyéb ásványok oldódását elősegíti (Curtis, 1978; Schmidt és McDonald, 1979; Kharaka et al., 1980, 1983).

A sekély felszín alatti vizek literenként általában milligrammos nagyságrendben tartalmaznak oldott szerves anyagokat, amelynek jelentős része (akár 90\%-a) humin- és fulvosavakból áll (Leenheer et al., 1974; Thurman, 1984). Az oldott szerves anyag mennyisége és a humin anyagok aránya általában nagyobb a telítetlen zónában, főleg a talajokban.

Meg kell jegyezni, hogy a szakirodalomban alig található kőolajokkal kapcsolatban nem levő hévizek aromás vegyületeivel foglalkozó dolgozat (Di Gioia et al., 2006; Barreiro et al., 2009). Kharaka et al. (1985) és az ebben idézett publikációk, a nagy szervesanyag-tartalmú vizeket (elsősorban acetát és propionát ionok) kőolajtelepekhez kapcsolódó rétegvizeknek (oil field water, továbbiakban: rétegvíz) tartják.

Di Gioia et al. (2006) egy olaszországi (Calabria), nagy kéntartalmú hévforrásban vizsgálták kéntartalmú komponensek (elemi kén és poliszulfid anionok), fenolok, telített és telítetlen alkoholok és zsírsavak koncentrációit, mely utóbbiakat alga eredetűnek határozták meg. González-Barreiro et al. (2009) négy spanyolországi (Ourense) forrásból mutattak ki számos szerves vegyületet, köztük alifás és illó aromás szénhidrogéneket, heteroatomos és 
heteroaromás vegyületeket. A szerzők a mért szerves molekulákat alga-, huminsav- és szárazföldi növény-eredetű bomlástermékeknek tartják.

Geotermális rendszereken belül is folyik oldott szerves vegyületek (és az ezekkel kölcsönható szervetlen alkotók, például szulfáttartalom) vizsgálata (A. Vetter szóbeli közlése), de a kutatás tárgya főleg a baktériumok és a mikrobiális közösség foszfolipid biológiai markerek segítségével történő vizsgálata (Vetter et al., 2011).

A rétegvizekben található szerves savanionokat Kharaka et al. (1985) és az általuk említett szerzők a kerogén (Jurg és Eisma, 1964; Eisma és Jurg, 1967; Kharaka et al., 1983) és kőolaj gyanta és aszfaltén frakcióinak (Kharaka et al., 1985) termokatalitikus vagy bakteriális bomlástermékeinek tekintik.

A (kőolaj előfordulásokhoz kapcsolódóan előforduló) rétegvizek szervesanyag-tartalma jóval nagyobb lehet, mint a felszíni vizeké. Ezek hömérséklete általában 40 és $200^{\circ} \mathrm{C}$ között van, főleg acetát és egyéb karbonsav észterek találhatóak bennük, akár g/l-es koncentrációban (Willey et al., 1975; Carothers és Kharaka, 1978, Surdam és Crossey, 1984). Mennyiségüket főleg a hőmérséklet és a tárolókőzet kora határozza meg. $80^{\circ} \mathrm{C}$ körüli ugrásszerü megjelenésük után koncentrációjuk csökken a növekvő hőmérséklettel, (Kharaka et al., 1983). Ennek oka a vegyületek dekarboxileződése, ami széndioxid és szénhidrogén gázok keletkezésével jár (Kharaka et al., 1983; Drummond and Palmer, 1985; 1986).

Rétegvizekben aminosavat mutattak ki. Degens et al. (1964) az aminosavak dúsulásáért az agyagok membránszűrő tulajdonságával magyarázta. Rapp (1974) megállapította, hogy az olajmezőkkel kapcsolatban álló források vizében is megjelenő aminosavak a prekurzor fehérjék kémiai lebomlását valószínűsítik mikrobiális folyamatok helyett. Rövid szénláncú szénhidrogén gázokat és nem illékony szerves savakat is kimutatott a vizekből.

A rétegvizekben a szénhidrogén gázok mennyisége nő a növekvő nyomással, csökkenő sótartalommal és $75^{\circ} \mathrm{C}$ felett a növekvő hőmérséklettel (Haas, 1978; Randolph, 1978). A folyékony szénhidrogének koncentrációja szintén nő a növekvő hőmérséklettel és a csökkenő sótartalommal (Price, 1978).

Aromás vegyületek (főleg PAH-ok és fenolok) koncentrációit - az említett rétegvizeken és a kőolajkutatással vagy migrációval kapcsolatban vizsgált üledékeken kívül - elsősorban felszíni vizekben és még inkább ezek recens üledékeiben vizsgálták. Wakeham et al. (1979, 1980) három svájci és egy Észak-amerikai tó üledékeiben vizsgálta a PAH-ok eloszlását. Eredményeik alapján a recens tóüledékekben lejátszódó korai diagenezis jelentős $(\mathrm{mg} / \mathrm{kg}$ nagyságrendű) PAH (főleg perilén és fenantrén) forrása lehet. A PAH-ok és alkil homológjaik minőségi és mennyiségi eloszlása tavanként eltérő. Zakaria et al. (2002) vizsgálták a PAH 
szennyezők mennyiségét és eloszlását malajziai folyoüledékekben és tengerparti üledékekben, és megállapították ezek fö forrásait.

A magyarországi hévizek oldott szerves anyagaival többen is foglalkoztak. Varsányi (1985) és Varsányi és Bertalan Balogi (1985) a - föleg DK-magyarországi - felszín alatti és hévizek huminsavait és ezek viselkedését vizsgálta. Azt állapították meg, hogy a különféle korú és eredetű vizek szerves anyagában a huminsavak mennyisége eltérő. A hévizekben a huminsav lebomlik, és nem-humin szerves anyagok keletkeznek, valamint megállapítható, hogy a mélyebb vizekben elöforduló huminsavak az $\mathrm{E}_{4} / \mathrm{E}_{6}$ abszorbancia mérések alapján aromásabb karakterüek, mint a sekélyebbekből származók. Varsányi (1994) és Vető et al. (1998) szervetlen alkotók, széndioxid, KOI és szénhidrogén gázok eloszlása alapján kimondják, hogy a szerves anyag aerob, majd mélyebben anaerob bomlása, ami $\mathrm{CO}_{2}$ termeléssel jár, alapvetően befolyásolja a mélységi vizek hidrogén-karbonát-, nátrium-, ammónia- és jódtartalmát. Varsányi et al. (1997) 25, DK-Magyarországról származó meteorikusnak tekintett $\left(\mathrm{Cl}^{-}<138 \mathrm{mg} / 1,-12,7<\delta^{18} \mathrm{O}<-8,4\right)$ víz vizsgálata alapján megállapította többek között a következőket: a legmélyebbröl, azaz a pontusi - pannon (most már felső- és alsópannon) határ közeléből származó vizek a meteorikus komponens mellett az alsóbb rétegekből kipréselődött rétegvizet is tartalmaznak. A nátrium-, lítium-, bór- és fluoridion fő forrásaként az aluminoszilikát ásványok bomlását jelöli meg. A széndioxidot szerves eredetünek tekinti, és megállapítja azt, hogy az acetátból történő metánképződés a szervesanyag-tartalomtól függetlenül történik a hévizekben. Varsányi et al. (2002) a vizekben oldott szerves anyagok minőségét vizsgálva megállapította, hogy a huminsavak, alkilfenolok és alifás savak koncentrációja és a vegyületek aromássága a hőmérséklettől, a szerves geokémiai fáciestől (lerakó környezet, szerves anyag típusa), és a litológiától egyaránt függ.

A korábban már említett OKI - MÁFI - MTA GKKI együttmüködésből sok publikáció készült (pl. Kárpáti et al., 1999; Vető és Bertalan-Balogi, 1994; Vető et al., 2004a), amelyek egy részében (a későbbiekben) én is közremüködtem (pl. Sajgó et al., 2007a, b; 2008; 2009; 2010; Fekete et al., 2008; 2009; 2010a, b; 2011). A kutatás során tanulmányozott több mint 500 hévíz közül kb. 200-ban, föként a nagyobb hőmérsékletü hévizekben jelentős mennyiségben (akár $10 \mathrm{mg} / 1$ felett) találtak különféle oldott szerves vegyületeket: mono-, di-, poli- és heteroaromás szénhidrogének, fenolok és. alkil-származékaik, alkil-benzolok, alkiltiofének, tetrahidrotiofén, tetrahidrotiopyrén alkil származékai, alkil-dihidro-indének, etilindán, alkil-fenolok, tetralin és metil származékai, naftalin és alkil származékai, 1,1-bifenil és metil, etil és hidroxi származékai, alkil-benzotiofének, 1,2-dihidro-acenaftilén, dibenzofurán és metil származékai, 9H-fluorén és metil származékai, xantén, dibenzotiofén és metil 
származékai, fenantrén és metil származékai, 9H-karbazol, mono-, di- és trimetil-karbazolok, fluorantén, pirén, 11H-benzofluorén és zsírsavak (C6-C16) stb. (összesen több mint 500 vegyület) (Sajgó et al., 2007a).

A szerves anyagok alapján a vizeket három csoportba sorolták (Kárpáti, 1999):

1) A termál karsztvizek kis sótartalmú és kis szervesanyag-tartalmú vizek, esetenként jelentős kén (pl. Hévíz) vagy radontartalommal (pl. Gellért-hegyi források).

2) Karbonátos kőzetből származó nagy kéntartalmú vizek. Jellemzőjük a nagy keménység és sótartalom, a sokfajta szerves kénvegyületet jelenléte és a fenolok hiánya, vagy kisebb mennyisége (főleg Nyugat-Dunántúlon). Ezek víztartó rétegei szénhidrogén-telepek alatt is elhelyezkedhetnek (pl. Zalakaros).

3) A törmelékes kőzetekből származó mélységi vizek, amelyek közül a $80^{\circ} \mathrm{C}$-nál melegebbek nagy mennyiségben tartalmaznak természetes eredetü illékony szerves anyagokat, míg a hidegebbek huminanyagokban dúsak (elsősorban a Dél-Alföldről származóak).

A vizsgált hévizekről az alábbi megállapításokat tették (Kárpáti, 1999):

- a humin- és fulvosavak jelen vannak a felszíni és a kismélységű felszínalatti vizekben is, de kémiai összetételük más, mint a termálvizekből vizsgáltaké. A huminsav-tartalom az emelkedő hőmérséklettel/növekvő mélységgel minőségi és mennyiségi változásokat mutat;

- a kis mélységből termelt vizek bakteriális eredetü metánt és igen kevés nehezebb szénhidrogén gázt tartalmaznak oldott állapotban, míg a nagyobb mélységü termálvizekben a termikus eredetü szénhidrogén gázok is megjelennek (a szénhidrogén gázok termikus képződése folyik), majd uralkodóvá válnak;

- a kb. $80^{\circ} \mathrm{C}$ kifolyási hőmérsékletü vizekben mono-, di-, poli- és heteroaromás szénhidrogének jelennek meg és koncentrációjuk nő a hőmérséklet;

- a $90^{\circ} \mathrm{C}$ melegebb hévizekben megjelennek: előbb a fenolok, majd a zsírsavak; a hőmérséklet emelkedésével nő a koncentrációjuk és dominánssá válnak;

- az egyes homológ sorokon belül az emelkedő hőmérséklettel csökken a nagyobb szénatomszámú tagok relatív koncentrációja a kisebbek javára (a rövidebb szénláncúak aránya nő), vagyis demetileződés játszódik le.

A szerves anyag lebomlás valószínű reakciója a hidrolitikus diszproporcionálódás: az oldhatatlan szerves anyag (kerogén) és a kolloidállapotú huminsavak degradálódása a víz aktív részvételével megy végbe, miközben kisebb, vízben jobban oldódó molekulák és széndioxid keletkeznek. A homológ sorokon belüli demetileződés is az említett mechanizmus szerint játszódik le. A reakciók során keletkező egyes mérgező termékek koncentrációja az 
ivóvízben megengedhetőnek sokszorosát is elérheti (Kárpáti et al., 1996b; Sajgó et al., 2007a).

Kutatásom során modell kísérletekben vizsgáltam a szerves anyagok érését (termikus bomlását) vizes közegben. A nagy hőmérsékletü, vizes közegben lejátszódó szerves kémiai reakciókat több szerző is kiterjedten vizsgálta és több összefoglaló jellegű publikáció is született ebben a témában (Katritzky et al., 2001, Siskin and Katritzky, 2001). A szakirodalomban fellelhető hasonló kísérletek más céllal, és általában más kísérleti körülmények között készültek, ennek ellenére bemutatom a kutatási témámhoz kapcsolódó tapasztalatokat az alapvető reakciók megismerése céljából.

A $200^{\circ} \mathrm{C}$-nál melegebb víz fizikai és kémiai tulajdonságai jelentősen eltérnek a $100^{\circ} \mathrm{C}$ alatt tapasztalttól. A sűrüség, a dielektromos állandó lecsökken, a disszociációs állandó nő. Ennek következtében a víz savas és lúgos katalizátorként, oldószerként és reaktánsként egyaránt részt vesz a reakciókban. A gyökös helyett az ionos szerves reakciók válnak jellemzővé. A hőmérséklet emelkedésével könnyebben következik be a kötések felszakadása, intenzívebbé válnak a kondenzációs és hidrolitikus reakciók (Siskin and Katritzky, 2001). A vizes közegben végzett hőkezeléses kísérletek alkalmasak az alacsonyabb hőmérsékleten, de geológiai léptékű időskálán lejátszódó természetes folyamatok modellezésére (Siskin and Katritzky, 2001).

Röviden ismertetem a fent említett szerző által vizsgált modellvegyületek $320^{\circ} \mathrm{C}$-ig (ez volt a hőkezeléses kísérleteim felső határa) jellemző reakcióit. Két fontos dolgot meg kell említenem: a rozsdamentes acél reaktorok a vizsgálatok alapján nem befolyásolják a reakciók lejátszódását (Hoering, 1984; Torry et al., 1992), illetve a vízben nem mutatható ki számottevő fémtartalom 10 napos, $300^{\circ} \mathrm{C}$-os kezelés után sem (Kuhlmann et al., 1994). Az alább felsorolt hőkezelések mindig oxigénmentes környezetben történtek.

- Az alifás komponensek föleg katalizátor jelenlétében (platina vagy savas agyagásványok) vagy ciklohexán közegben reaktívak. Siskin et al. (1990) mutatta ki alkilbenzolok keletkezését 1-decin-ből (1,4-dioktilbenzol és 2,4-dioktiltoluol, $250^{\circ} \mathrm{C}$ os vízben, 2,5 nap alatt), feltehetöleg trimerizációs reakción keresztül.

- A benzol, a naftalin (Katritzky et al., 1994a), a fluorén és a fenantrén (Katritzky et al., 1997) nem reaktív $320^{\circ} \mathrm{C}$-ig, bár az alkil oldalláncok növelik a reaktivitást. Sztirolból polisztirol keletkezik $250^{\circ} \mathrm{C}$-os vízben öt nap alatt.

- A pirrolok és indolok többé-kevésbé stabilak, a pirrol $1 \%$-a alakul indollá $250^{\circ} \mathrm{C}$-on, 5 nap alatt. 
- A tiofének és a benzotiofén vízben nem reaktívak $350^{\circ} \mathrm{C}$-ig (Rideout and Breslow, 1980; Katritzky et al., 1992).

- A dimetilfuránok $250^{\circ} \mathrm{C}$-on, 30 perc alatt, $\mathrm{D}_{2} \mathrm{O}$ közegben hexándiont (Kuhlmann et al., 1994), a dihidrobenzofuránok fenolokat (Katritzky et al., 1994b) képeznek, ami azt mutatja, hogy a furán gyürü felnyílásra hajlamos. Ezzel együtt az egy órán át, $460^{\circ} \mathrm{C}$ on kezelt dibenzofurán nem bizonyult reaktívnak (Katritzky et al., 1994a).

- Savas katalizátor jelenlétében (vizsgált savak: foszforsav, hangyasav) a heteroaromás vegyületek számtalan változatos reakcióban vesznek részt. A transzalkiláció és DielsAlder reakciók (cikloaddíció, polimerizáció) mellett megfigyeltek heteroatomos gyürü felnyílást (feltehetőleg retro Diels-Alder reakcióval) és heteroatom vesztést, és az ezzel esetenként együtt járó benzolkeletkezést is (Katritzky et al., 2001).

A fentiek összefoglalásaként a következő reakciókról feltételezhetjük, hogy részt vesznek a poli- és oligomolekulák lebomlásában és az alkilbenzolok, policiklikus aromás szénhidrogének és heteroaromás vegyületek keletkezésében:

- a poli- és oligomolekulák lebomlásával (C-C és C-heteroatom kötések felszakadása) alkilbenzolok, PAH-ok és heteroaromás vegyületek keletkeznek;

- alkilbenzolok és PAH-ok keletkeznek aromatizációval és polikondenzációval (cikloaddíciós és polimerizációs reakciók), illetve heteroatom vesztéssel;

- a heteroaromás vagy heterociklikus vegyületek vagy molekularészek felbomlásával egy vagy több gyürüs alkilezett aromás vegyületek és fenolok keletkeznek.

Nem egy modellvegyületen (pl. benzol, tiofén stb.), hanem természetes szerves anyagokon végzett aqutermolízis kísérletek (amelyekben az aromás vegyületek vizsgálata a cél) az irodalomban alig fellelhetők. Az összetett szerves anyagon végzett kísérleteket tekintve hasonló eredményre számíthatunk, csak az összetett molekulaszerkezet és a reakciókban résztvevő sokféle különböző molekularész miatt a párhuzamos reakciók nyomon követése kevésbé, vagy nem lehetséges. Ligniten végzett vizes pírolízis kísérletekben Barbier et al. (2012) mutatta ki illó aromás vegyületek keletkezését. A vizes hökezeléses kísérletek nagy arányban foglalkoznak a nyersanyagtermelés lehetőségeivel. Behar et al. (2003) hasonló kísérleteket végzett, szintén ligniten, ám ebben az esetben a keletkező szénhidrogén gázok mennyiségét és arányát vizsgálták vizes zárt, illetve víz nélküli nyitott és zárt hőkezelésekben. Bitumenen (Kapadia et al., 2012) és szénen ( $\mathrm{Su}$ et al., 2006) is történtek hasonló vizsgálatok. 


\section{Földtani háttér, minták és módszerek}

\subsection{Geológiai háttér}

A későbbi összehasonlítás miatt célszerü röviden ismertetnem azon területek földtani jellemzőit, ahonnan több hévíz minta is rendelkezésemre áll. Ezek a MakóHódmezővásárhelyi-árok, a Pusztaföldvári-hát, a Békési-medence és a Jászsági-medence.

Az alföldi pannon részmedencék a Pannon-medence középső-miocén extenziója során alakultak ki. Az egyes részmedencék többé-kevésbé kapcsolatban álltak egymással, feltöltődésük során alapvetően hasonló üledékképződési környezetek váltották egymást. Mivel a behordás iránya főleg ÉK-i (Békési-medence és Pusztaföldvári-hát), illetve elsősorbanÉNY-i (Makó-Hódmezővásárhelyi-árok és Jászsági-medence) volt, a részmedencék időben kissé eltolódva töltődtek fel.

A medence aljzata a legmélyebb részeken részben ismeretlen, másutt főleg gyűrt variszkuszi csillámpala és gneisz sorozatok és egyéb metamorfitok, perm törmelékes és vulkáni sorozatok, alsó és középső triász sziliciklasztos és karbonátos képződmények alkotják.

A területet 10-12 millió éve öntötte el a Pannon-tó, melynek fokozatos feltöltődése nyomán eleinte mélyvízi, később progradáló lejtő- majd delta fáciesek jellemzik a lerakódott üledékeket.

Juhász $(1992 ; 1993 ; 1994)$ alapján az alábbi fácies asszociációk különíthetőek el a pannon rétegsorban: pelites alapképződmények, abráziós konglomerátum, mélyvízi turbiditek, pelites szublitorális, illetve lejtő fácies, litorális és delta fácies, alluviális síkság, mocsárerdei lignit és barnakőszén, valamint vulkáni képződmények.

A legidősebb medenceüledékek kora jelenleg vitatott. Badics et al. (2011) szerint, ha kárpáti bádeni korú üledékek egyáltalán előfordulnak a Makói-árokban, akkor csak a Pusztaföldvárihát nyugati szárnyán lehetnek. Általánosan a kristályos aljzatra települtek a pannóniai üledékek. Az alaphelyzetű mélyvízi mészmárgát a behordott sziliciklasztos üledék arányának növekedésével márga, majd agyagmárga váltotta fel (Endrődi Formáció Tótkomlósi, illetve Nagykörüi Tagozata). Amint a fö üledékforrást jelentő progradáló lejtő közelebb került, durvább szemcsés üledékek is megjelentek (Vásárhelyi Tagozat).A kiemelt aljzatblokkok közelében kavicsos, durva homokos betelepülések is találhatók (Dorozsmai Tagozat). A partközeli területeken abráziós eredetü Békési Konglomerátum rakódott le. A Vásárhelyi 
Tagozat fedője az akár 1100 méter vastagságot elérő turbiditsorozat, a Szolnoki Homokkő Formáció. Az agyag-aleurit lejtőüledékek (Algyői Formáció) vastagsága jellemzően néhány száz méter, de a Makói-árokban néhol az 1000 métert is megközelíti (Pogácsás et al., 1988). A progradáció további előrehaladtával a deltafront, majd a deltasíkság képződményei kezdtek lerakódni (Újfalui Formáció). Ennek fedőjeként alluviális, a mederövekben részben homokos, az ártereken aleurolitos-agyagmárgás üledékek települnek (Zagyvai Formáció). A Nagyalföldi Tarkagyag Formáció többnyire nehezen különíthető el a Zagyvai Formációtól.

A Pannon-medence területén a negyedidőszaki üledékképződést az egyes részterületek eltérő sebességű emelkedése, illetve - az Alföldön leginkább - süllyedése és az éghajlat változása befolyásolta. A Pannon-tó feltöltődése után kialakult folyók többnyire meanderező medrei még az elmúlt néhány tízezer év során is jelentősen változtatták helyzetüket (Rónai 1985, Gábris és Nádor 2007). A medence délkeleti részén az üledékképződés a késő-miocéntől a kvarterig folyamatos (Juhász et al, 2006).

A folyóvízi üledékek vastagsága a mélymedencék területén eléri a 800 métert, és folyóvízi (zátonyokon lerakódott) durvaszemcsés homokból, valamint finomabb ártéri üledékekből áll. A Battonya-Pusztaföldvári háton a kvarter üledékek vastagsága kisebb. A felsőpleisztocénben gyakoriak az eolikus képződmények (lösz, löszös homok, homokos lösz) is (Urbancsek 1977).

Az egyes részmedencék között jellegzetes különbségek is megfigyelhetők, az eltérő időben és tektonikai környezetben zajlott feltöltődés következtében (Juhász, 1993; 1994). A Makói-árok feltöltődésének iránya alapvetően ÉNY-i, míg a Békési-medencében és a Jászsági-medence keleti részén az ÉK-i és ÉNY-i irány is jól megfigyelhető. Emellett a Jászsági-medencére jellemző a partmenti és nyíltvizi fáciesek összefogazódása, ami a relatív vízszint jelentős ingadozásaira utal (Juhász, 1993). A két szállítási irányból eltérő üledékanyag érkezett: ÉNY-i irányból homokban gazdag turbiditek, ÉK-ről jellemzően finomszemcsés üledékek hordódtak a medencébe (Juhász, 1994). Csizmeg et al (2011) kimutatták, hogy a Jászsági-medence süllyedése korábban és gyorsabban következett be, mint a Békési medence északi részéé, így ott a felfütés és a szénhidrogén keletkezés (föleg gáz) hamarabb játszódott le.

$\mathrm{Az}$ egyes részmedencék szerves geokémiai vizsgálata általában a szénhidrogén-potenciál felmérése során történt meg. A legfontosabb szénhidrogén anyakőzet az alsó-pannon Endrődi Márga Formáció, emellett Badics et al. (2011) a Makói-árokban a pannon legalján elhelyezkedő nem hivatalosan elfogadott „Makói Tagozat”-ot is elég jó (fair) kőolaj és földgáz anyakőzetnek írta le. Az Endrődi Formáció TOC értékei jellemzően 0,5-2\% közöttiek, 
de a Tótkomlósi Mészmárga Tagozatban 2-4\% között változnak. Ez utóbbi olajipari szempontból szintén fair besorolású.

A márga fedőjében települő finomszemü üledékek (Szolnoki Formáció, Algyői Formáció) szervesanyag-tartalma változó, általában $1 \%$ alatti.

A felső-pannóniai üledéksorozat finomszemü üledékei változó, akár 10\%-ot elérő TOC értékkel rendelkeznek, de érettségük alacsony. Ezekben biogén eredetű földgáz képződés történhet. A leírt anyakőzetek szerves anyaga általában III. típusú (gáz- vagy kevert gáz/olajképző), csak részben tartalmaznak II. típusú (olajképző) kerogént. A már megtalált szénhidrogén előfordulások érettsége és rokonsága változatos. Szerves geokémiai módszerekkel igazolt anyakőzetek jelenleg nem találhatók.

Clayton és Koncz (1990) alapján a sok fúrásban megtalálható szén-dioxid jelentős részben az aljzatbeli karbonátos kőzetek termikus átalakulásából származik. Vető et al. (2004) alapján a szénhidrogén gázok bakteriális és termikus keletkezése akár egymással átlapolva is zajlik.

Számos kőzetösszlet szolgálhat tárolókőzetként a medencékben. Ezek közé tartoznak a repedezett aljzat karbonátos és metamorf képződményei, középső-miocén homokkövek, konglomerátumok és mészkövek, az alsópannóniai báziskonglomerátum és homokkő, az Endrődi Márga, Szolnoki, Algyői és az Újfalusi Formáció.

Összegezve elmondható, hogy a felszín alatti vizekben megtalálható aromás szerves anyagok forrásaként a III., esetenként II. típusú kerogén, az egykori partmenti környezetekben felhalmozódott lignit és barnakőszén, a kőzetek oldható szerves anyaga (bitumen), illetve a kevéssé érett üledékek és talajok humin anyaga egyaránt szolgálhat.

\subsection{Hévízminták}

A kutatás keretében közel negyven, Magyarország területéről származó hévízminta szervetlen, stabilizotópos és szerves összetételbeli mérési eredményét használtam fel. A kiválasztott aktív termelőkutak szürőzése 411 - 2264 m mélység tartományban van; a vízadó kőzetek főleg késő-pannóniai koriak. A vizek kifolyó hőmérséklete $38^{\circ} \mathrm{C}$ és $99^{\circ} \mathrm{C}$ közt változik, ám a hőmérséklet értékek nem mutatnak szoros összefüggést a kutak mélységével, ami a földtani felépítés és a geotermikus gradiens változatosságával magyarázható.

Magyarázatra szorul, hogy miért nem a talphőmérsékleteket használom az eredmények értelmezése során. Ennek oka a talphőmérséklet adatok bizonytalansága. Mivel egyes kutak több rétegre is szürőzöttek, bizonyos esetekben akár 600 méteres intervallumban, a termelt víz 
komponensek más-más hőmérsékletüek lehetnek. Ilyen esetben a keverék víz kifolyási hőmérséklete jobb értelmezést tesz lehetővé a keverék kémiai paramétereinek értékelésekor. Ugyanilyen megfontolásból használom a mélység jellemzésére a szürőközép mélységét.

Természetesen geokémiai mutatók számításához szükséges meghatározni a kutakra jellemző egyensúlyi réteghőmérsékletet. Jelen kutatásban ez nem volt célom, mégis a további vizsgálatok megalapozásaként röviden ismertetem ennek módszerét.

A kifolyó és rétegvíz hömérséklet közötti összefüggés matematikai leírásához mindenképpen szükséges a fakadási mélység, a kifolyó vízhőmérséklet, a geotermikus gradiens és a vízhozam ismerete. Ezeken kívül Jencsel et al. (2007) szerint a hővezetés figyelembe vételével két állandó is adódik az általuk felállított egyenlethez, amely így néz ki:

$$
T_{\text {réteg }}=H \cdot g+T_{k i}-I \cdot\left[e^{-b} \cdot\left(\frac{H}{I}\right)^{a}\right],
$$

ahol $\mathrm{T}_{\text {réteg }}$ a mélységhez tartozó réteghőmérséklet $\left({ }^{\circ} \mathrm{C}\right), \mathrm{T}_{\mathrm{ki}}$ a kifolyó víz hőmérséklete $\left({ }^{\circ} \mathrm{C}\right), \mathrm{H}$ a fakadási mélység $(\mathrm{m})$, I a vízhozam $\left(\mathrm{m}^{3} / \mathrm{min}\right)$, g az országos gradiens $(0,04464)$, a és b együtthatók, értékük 0,8709063262, illetve 2,57917301. Ezt az összefüggést 175 Pannonmedencei kúton tesztelték, és a korábbi módszerektől szignifikánsan jobb közelítéseket értek el az új egyenlettel. Ennek alapján megfelelőnek tartom ezt az összefüggést alkalmazni a további kutatás során.

A vizsgált minták részben megegyeznek a Vető et al. 2004a által gázképződés szempontjából tárgyaltakkal. A minták zöme nátrium-hidrogén-karbonátos (vagy ahhoz nagyon közel áll), a három $0 \%$-hez közeli $\delta^{18} \mathrm{O}_{\mathrm{SMOW}}$ értékủ nátrium-klorid fáciesủ.

A minták földtani felépítésükben lényegesen eltérő területekről származnak (1. ábra, 3. táblázat). A harmad- és negyedidőszaki üledékek vastagsága 200 és $7000 \mathrm{~m}$ között változik, az alapkőzet mélységétől függően. A felső-pannóniai és az erre települő rétegek, illetve az alsó-pannóniai üledékek különböző kőzettani összetétellel jellemezhetők, és így vízföldtani szempontból eltérő tulajdonságokkal rendelkeznek. A felső-pannóniai alsó rétegekben sok helyen megtalálható homokos-kavicsos deltaüledékek kiváló vízvezető képességének köszönhetően a meteorikus (és az egykori meteorikus) vizek rövid idő alatt nagyon mélyre jutnak. Az alsó-pannóniai képződmények felső részén kis porozitású, rendkívül kis vezetőképességü rétegek települnek. 


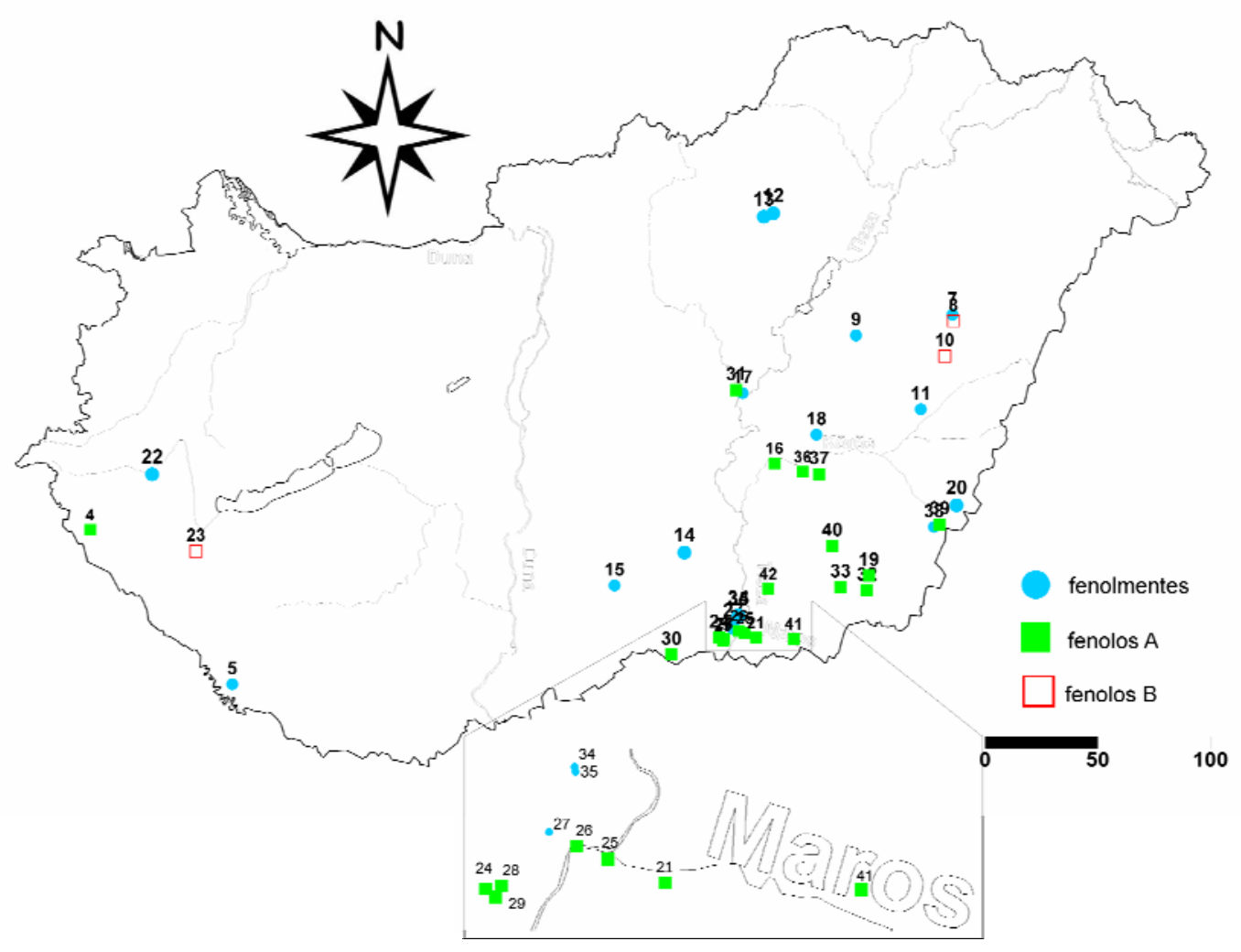

1. ábra. A mintázott hévízkutak területi eloszlása. A csoportok magyarázata a 4. fejezetben található.

Közel 53000 pórusnyomás és vízszint adat alapján Tóth és Almási (2001) állított fel modellt az Alföld hidrogeológiai viszonyaira. Két fő rendszert különítettek el: 1) felső, fedetlen (unconfined) gravitáció által vezérelt áramlási zóna; 2) alsó, fedett (confined), túlnyomásos zóna. A két zóna közötti határ 200 és 1700 méter közötti mélységben húzódik, az átmenet a kettő között fokozatos (föleg a mély részmedencékben) és hirtelen (föleg a kiemelt helyzetü aljzat felett) is lehet. A túlnyomásos rendszerből vetőkön és törészónákon keresztül felfelé áramlás történik.

A túlnyomás oka lehet az, hogy az üledékek kompakciója nem tart lépést a gyors medencesüllyedéssel és betemetődéssel, bár Tóth és Almási (2001) modellje ennek okaként a tektonikus kompresszió hatását jelölik meg.

A felfelé áramló pórusvizek meteorikus vizekkel történő keveredése (hígulása) nem az egyetlen folyamat, ami meghatározza a vizek jellemzőit, a változatos kémiai összetételek természetesen a kőzet-víz kölcsönhatással, a finomszemcsés üledékek ionszürő és -cserélő tulajdonságaival és nem utolsó sorban az eltérő szervesanyag-tartalommal és annak minőségével magyarázható. 
Szerves anyagok kolloid és oldott állapotban vannak jelen felszín alatti vizeinkben. Kolloidként nagy molekulasúlyú, föleg humin anyagok (huminsavak, fulvosavak stb.) fordulnak elő. Ezek molekulamérete elektrolitfüggő, tehát asszociációs - disszociációs tulajdonságaik függenek a víz fiziko-kémiai paramétereitől (hőmérséklet, $\mathrm{pH}$, redox potenciál, nyomás, egyéb oldott alkotók stb.).

Az oldott állapotban levő szerves anyagok koncentrációja csekély oldhatóságuk miatt általában kicsi (leszámítva a könnyü zsírsavak sóit, pl. acetátokat). Mivel a szénhidrogének közül az aromások kissé oldódnak vízben, az alkánok vízoldhatósága pedig $100^{\circ} \mathrm{C}$ felett exponenciálisan nő, nem meglepő, ha kőolaj-előfordulások közelében olajszármazékokat tartalmazó hévizek találhatók (bővebben az 1.2 fejezetben). A korábban említett kutatások alapján azonban bizonyos hőmérséklet felett $\left(\mathrm{kb} .80^{\circ} \mathrm{C}\right)$ szénhidrogén telepekkel közvetlen kapcsolatban nem levő hévizekben is azonosíthatóak. Sok esetben nagy mennyiségben (>10 mg/l) jelen vannak illékony szerves vegyületek: mono-, di-, poli- és heteroaromás szénhidrogének, fenolok, zsírsavak $\left(\mathrm{C}_{6}-\mathrm{C}_{16}\right)$ és egyéb, olyan szerves összetevők is, amik nem kőolajokból való származásra utalnak.

A vízmintavételeket a Magyar Állami Földtani Intézet (MÁFI) végezte 2001-2002-ben. A mintavétel légmentesen záródó, tiszta polietilén mintavevő palackokba történt. A mérések néhány napon belül elkészültek, addig a mintákat $4{ }^{\circ} \mathrm{C}$ alatt tárolták. A szerves analitikai mérésekhez 2,5 liter vizet vettek oldószerrel kimosott, $200^{\circ} \mathrm{C}$-on kiszárított, üvegkupakkal záródó üvegekbe. A szállítás és tárolás (legfeljebb 2-3 nap) során a mintákat $4^{\circ} \mathrm{C}$ alatt tartották.

A hévizek stabilizotópos összetételének meghatározása a MTA Atommagkutató Intézetben történt, az eredményeket a szokásos $\delta$ értékben adom meg $\left(\delta=\left(\mathrm{R}_{\text {minta }}\right.\right.$ -

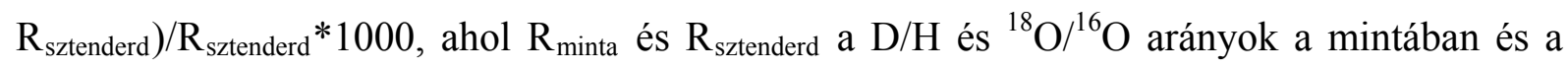
sztenderdben) a V-SMOW referenciához viszonyítva, \%o-ben. A mérés hibahatára $\pm 2 \%$ ( $\delta \mathrm{D})$, illetve $\pm 0,1 \%$ o $\left(\delta^{18} \mathrm{O}\right)$ volt.

A rutin vízkémiai vizsgálatokat a MÁFI-ban készítették. Az oldott szervetlen ionokat ionkromatográfiásan és ICP-AES spektrometriával (Jobin Yvon ULTIMA 2C) határozták meg. A nyomelem vizsgálatok ICP-MS technikával (VG PlasmaQuad II STE) készültek.

A szerves kémiai analíziseket az Országos Közegészségügyi Intézetben Kárpáti Zoltán és munkatársai készítették. A minőségi azonosításokat a tömegspektrumok és a retenciós idők alapján Kárpáti Zoltán és Sajgó Csanád végezték. Mennyiségi vizsgálatok az alábbi vegyületcsoportok esetében készültek: illékony vegyületek (halogénezett szénhidrogének, alkilbenzolok és naftalin), poliaromás szénhidrogének (PAH) és fenolok. A mennyiségi 
meghatározásokhoz sztenderdeket használtak (32 db környezeti szempontból jelentős halogénezett szénhidrogént, $14 \mathrm{db}$ alkilbenzolt, $15 \mathrm{db}$ PAH-vegyületet és $16 \mathrm{db}$ fenolt). Az illékony vegyületek meghatározását szilárd fázisú mikroextrakciós módszerrel (SPME) végezték gázkromatográf-tömegspektrométer együttesen (HP 5890 GCMS), EPA (Elektronikus Periodika Adattár) 524.2. és EPA 8260 alapján (hélium vivőgáz, $250^{\circ} \mathrm{C}$ splitless injektor; kemence fütés programozása: $40^{\circ} \mathrm{C}, 6^{\circ} \mathrm{C} /$ perc, $230^{\circ} \mathrm{C}, 10$ perc).

A komponensek mennyiségi meghatározása a hévizek csoportosítása esetében relatív, mert a csúcsok területe alapján történt. Az ujjlenyomatszerüen vizsgált, azonosított vegyületeket homológ soronként összegeztem.

A policiklikus aromás szénhidrogének (2-5 gyürüsök) mennyiségi mérése folyadékkromatográfiásan (HPLC) történ, az EPA-550.1 alapján, Phenomenex Security Guard védőkolonna $(4 \times 3,0 \mathrm{~mm}, 5 \mu \mathrm{C} 18)$ és Supelcosil LC-PAH $(250 \times 4.6 \mathrm{~mm} \mathrm{5 \mu} \mathrm{C18)}$ analitikai oszlop használatával. Mérési paraméterek: $\mathrm{T}=35^{\circ} \mathrm{C} ; \mathrm{ACN} /$ víz: 0 perc $=50 / 50,5$ perc $=50 / 50,25$ perc $=90 / 10,45$ perc $=100 / 0,50$ perc $=100 / 0,55$ perc $=50 / 50,60$ perc $=50 / 50)$.

A fenolokat extrakciós és származékképzés (acetát) utáni extrakciós módszerekkel gázkromatográfiásan határozták meg a vízmintákban, a rendelkezésre álló sztenderdek segítségével.

\subsection{Vizes hőkezeléses kísérletek}

A hévizekben oldott szerves vegyületek számos forrásból kerülhetnek a felszín alatti vizekbe. A beszivárgó csapadékvíz kezdetben a talaj szerves anyagával (elsősorban humin anyagokkal) kerül kölcsönhatásba, majd a felszín alatti vízrezsim részeként a folyamatos lassú szivárgás alatt (a víz öregedése során) az üledékek szerves anyagával (kerogén és bitumen), adott esetben szárazföldi eredetü szerves anyag felhalmozódással (lignitcsíkok) vagy szénhidrogén telepekkel kerülhet kapcsolatba.

A fenti elgondolás alapján az alábbi kísérleti anyagokat választottam ki a vizes fázisú hőkezeléses kísérletekhez:

A huminsav és fulvosav (HA és FA) minták elválasztása a Keszthelyi Tőzegből történt a Nemzetközi Huminanyag Társaság (IHSS, International Humic Substances Society) által javasolt módszerrel (http://www.ihss.gatech.edu/soilhafa.html). 
A mélységi hévízből származó, érett huminsav-fulvosav keverék (HAFA) egy Dél-keletalföldi 2103 méter mély, $92^{\circ} \mathrm{C}$ kifolyási hőmérsékletü hévízkútból származik (K-159, Makó, Benkő és Társa Kft.). Ennek a mintának az esetében az IHSS által javasolt huminsav-fulvosav elválasztási módszer (http://www.ihss.gatech.edu/aquatichafa.html) nem járt eredménnyel. A humin és fulvosav mintákat elválasztását Szegedi Tudományegyetem Kolloidkémiai Tanszékén végezték a fenti módszerekkel.

A SZÉN nevü minta a Dudari Lignitből származik, előkezelés nélkül.

A bitumen (BIT) mintát a Tiszapalkonya-I fúrás 1591,2 - 1591, 4 méter közötti szakaszából extrahálták (porítás után kloroformmal) az MTA Geokémiai Kutatóintézetben.

A csapadék szerves anyag (CSAP) egy müködő geotermikus kút szürőjéről származik, Hódmezővásárhelyről. A vízmintából liofilizálással készült a szerves anyag, Mohr Anita (ELTE, Mikrobiológiai Tanszék) közremüködésével.

A vizes fázisú hőkezeléses kísérleteket (aquathermolysis, vagy magyarosan aquatermolízis) $600 \mathrm{ml}$-es rozsdamentes acél reaktorban végeztem (Parr Instruments). $250 \mathrm{ml}$ desztillált vízbe 0,75 gramm nátrium-hidrogénkarbonátot tettem, és előzetes kezelés után $\left(250^{\circ} \mathrm{C}, 1\right.$ óra $)$ ebbe mértem be a kísérleti anyagot. Az előzetes kezelés az esetleg jelen levő, kis mennyiségü szerves anyag oxidálására és az oldott gázok részleges eltávolítására szolgált. Három mintán (FA, HA, SZÉN) oxidatív körülmények között is készültek kísérletek, amikor az oldat feletti gőztér levegő volt. Ezek tulajdonképpen előzetes kísérletek voltak, hogy megállapítsam, milyen kísérleti hőmérsékletekkel dolgozzam, ezzel magyarázható az eltérés a később alkalmazott hőmérsékletektől (lásd később). A felszínalatti vizekben jellemző reduktív viszonyok modellezéséhez a mintákhoz $50 \mathrm{mg}$ L-aszkorbinsavat (Reanal, alt. min.) adtam redukáló szerként, és a vízen és a reaktoron nitrogént (Messer, 4,8 min.) buborékoltattam keresztül, annak érdekében, hogy minél több oldott oxigént távolítsak el, és a levegőt a gőztérben nitrogénre cseréljem. A kezdeti túlnyomást 2 barra állítottam.

A bevezető, oxidatív körülmények között végzett kísérletekhez 25 mg FA, HA és SZÉN mintát mértem be, és ezeket 72 órán át tartottam $150^{\circ} \mathrm{C}, 200^{\circ} \mathrm{C}, 250^{\circ} \mathrm{C}$ és $300^{\circ} \mathrm{C}$ hőmérsékleten a FA esetében, illetve $220^{\circ} \mathrm{C}, 250^{\circ} \mathrm{C}, 300^{\circ} \mathrm{C}$ és $320^{\circ} \mathrm{C}$ hömérsékleten a HA és a SZÉN esetében. Az eredmények alapján a reduktív kísérletekben a $220^{\circ} \mathrm{C}, 250^{\circ} \mathrm{C}, 300^{\circ} \mathrm{C}$ és $320^{\circ} \mathrm{C}$-os kísérleti hőmérsékleteket alkalmaztam, és minden mintából 100 mg-ot mértem be. Vak és csak aszkorbinsavat tartalmazó mintákon is készültek kísérletsorozatok. A mintavétel szobahőmérsékleten történt, mintavevő szelepen keresztül, a reaktor kinyitása nélkül.

A termékek mennyiségi és minőségi meghatározását az EKOL laboratóriumban (Elválasztástechnikai Kutató- és Oktatólaboratórium, ELTE, Budapest) Kramarics Áron 
végezte. A GC/MS mérések minden esetben egy Agilent 7890 gázkromatográf (GC) és Agilent 5975C inert XL tömegspektrométer (MS) együttesen történtek (Agilent Technologies, Germany), ami GERSTEL MPS2-XL automata mintavevővel és GERSTEL CIS4 programozható hőmérsékletü injektorral (PTV) üzemelt (GERSTEL GmbH, Germany). Az átvezető kapilláris, az ionforrás és a quadrupol hőmérséklete $250^{\circ} \mathrm{C}, 230^{\circ} \mathrm{C}$ és $150^{\circ} \mathrm{C}$ volt. $\mathrm{Az}$ MS szimultán SCAN/SIM módban végezte a méréseket. A célkomponensek koncentrációjának meghatározása a SIM (selected ion monitoring) adatokból történt, a SCAN mód az egyéb komponensek mérésére szolgált. Minden célkomponens meghatározása egy célion és két azonosító fragmens használatával történt. Minden esetben külső sztenderddel történő kalibrációt alkalmaztak.

A benzol és alkilbenzol-tartalom meghatározása statikus gőztér (static headspace) módszerrel történt az illékony aromás szénhidrogénekre vonatkozó Magyar Szabvány szerint (MSZ 14844:1998). $10 \mathrm{ml}$ kezelt oldatot vettem $20 \mathrm{ml}$-es, szeptummal záródó üvegbe, amibe előzőleg $5 \mathrm{~g}$ vízmentes nátrium-szulfátot (Reanal, alt. min.) mértem. Méréskor a mintát 15 percig tartották $80^{\circ} \mathrm{C}$-on, 600 fordulat/perccel rázatva. A gőztérböl $2,5 \mathrm{ml}$-es mintát vettek $2,5 \mathrm{ml}$-es gőztér fecskendővel, amit $105^{\circ} \mathrm{C}$-on tartottak. Az injektor 10:1 split aránnyal müködött, hőmérsékletét $10^{\circ} \mathrm{C}$-ról $12^{\circ} \mathrm{C} /$ másodperc sebességgel emelték $260^{\circ} \mathrm{C}$-ig, ami a mérés végéig állandó maradt. RTX-VMS (20 m x $180 \mu \mathrm{m}$ x $1 \mu \mathrm{m})$ kapilláris kolonnával került sor a komponensek elválasztására állandó $1 \mathrm{~mL} /$ perc hélium (5.0) vivőgázzal. A kemence programozása az alábbi volt: $40^{\circ} \mathrm{C}(2$ perc $), 40^{\circ} \mathrm{C} /$ perc, $100^{\circ} \mathrm{C}(0$ perc $), 20^{\circ} \mathrm{C} /$ perc, $160^{\circ} \mathrm{C}(0$ perc), $50^{\circ} \mathrm{C} /$ perc, $240^{\circ} \mathrm{C}$ (1 perc). A SCAN mérés tömegtartománya 40-300 AMU volt.

A policiklikus aromás szénhidrogének mérése Kolahgar et al. (2002) alapján történt. 40 ml-es üvegbe $10 \mathrm{ml}$ mintát és $2 \mathrm{ml}$ metanolt mértem. Méréskor a mintát egy $10 \mathrm{~mm}$-es Twister keverőbabával (GERSTEL, 0,5 mm fázisvastagság) 2 órán át keverték 1200 fordulat/perccel. A termális deszorpciós egység (TDU) hőmérsékletét $50^{\circ} \mathrm{C}$-ról fütötték 0,5 perc után $280^{\circ} \mathrm{C}$-ra $720^{\circ} \mathrm{C} /$ perc sebességgel, és 6 percig tartották ezen a hőmérsékleten. A meghatározandó vegyületek intenzívebb deszorpciója érdekében $50 \mathrm{ml} /$ perc vivőgáz áramot használtak. A splitless módban müködő TDU átvezető kapilláris hőmérséklete $280^{\circ} \mathrm{C}$ volt. A deszorpció alatt a lehűtött PTV injektorban gyűjtötték a komponenseket. A minta eltávolítása és a fejnyomás beállítása után az injektort $10^{\circ} \mathrm{C}$-ról $12^{\circ} \mathrm{C} /$ másodperc sebességgel $300^{\circ} \mathrm{C}$-ra fütötték, ami állandó maradt a mérés végéig. A komponenseket 10:1 split aránnyal vitték a kolonnára. Az elválasztáshoz HP-5MS (30 m x $250 \mu \mathrm{m}$ x $0.25 \mu \mathrm{m}$ ) kapilláris kolonnát alkalmazták állandó $1 \mathrm{ml} /$ perc hélium (5.0) vivőgáz árammal. A kemence programozása az alábbi volt: $50^{\circ} \mathrm{C}(1,5$ perc $), 20^{\circ} \mathrm{C} /$ perc, $180^{\circ} \mathrm{C}(0$ perc $), 15^{\circ} \mathrm{C} /$ perc, $250^{\circ} \mathrm{C}(0$ perc $), 3^{\circ} \mathrm{C} /$ perc, 
$275^{\circ} \mathrm{C}(0$ perc $), 5^{\circ} \mathrm{C} /$ perc, $305^{\circ} \mathrm{C}(0$ perc $), 40^{\circ} \mathrm{C} /$ perc, $320^{\circ} \mathrm{C}(5$ perc $)$. A SCAN mérés tömegtartománya 50-550 AMU volt.

A fenoltartalom meghatározása a 8040 EPA módszer alapján folyadék-folyadék extrakcióval és folyadékinjektálással történt. $10 \mathrm{ml}$ mintát sósavval történő savanyítás után extrahálták 1 ml hexánnal. A víztelenített extraktumból $1 \mu$ l-t fecskendeztek a PVT injektorba (hideg, splitless üzemmód, kvarcgyapot liner). A $40^{\circ} \mathrm{C}$-os injektort 0,2 perc várakozás után $720^{\circ} \mathrm{C}$ /perc sebességgel $280^{\circ} \mathrm{C}$-ra fütötték, és ezt a hőmérsékletet tartotta a mérés végéig. A komponensek elválasztásához HP-5MS (30 m x $250 \mu \mathrm{m}$ × $0.25 \mu \mathrm{m}$ ) kolonnát használtak, állandó $1 \mathrm{ml} /$ perc hélium (5.0) vivőgáz sebességgel. A kemence programozása az alábbi volt: $40^{\circ} \mathrm{C}(1$ perc $), 40^{\circ} \mathrm{C} /$ perc, $80^{\circ} \mathrm{C}(17$ perc $), 50^{\circ} \mathrm{C} /$ perc, $300^{\circ} \mathrm{C}(2$ perc $)$. A SCAN mérés tömegtartománya 50-550 AMU volt. 


\section{Vizes fázisú hőkezeléses kísérletek}

\subsection{Bevezetés}

A hévizekben vizsgált szerves vegyületek viselkedése összetett. Mint az irodalomból is látható, sok következtetést vonhatunk le a szerves anyag bomlástermékeinek és a vízkémiai paraméterek összevetéséből. Ahhoz, hogy megfelelő eredet- és érettségmutató paramétereket találjunk a természetes vizekben célszerü megvizsgálni, hogy a víz vándorlása során esetleges kölcsönható szerves anyag formák önmagukban, szabályozott körülmények között milyen viselkedést mutatnak hő hatására.

A vizes fázisú hőkezeléses kísérletekkel (vizes pirolízis, vagy még inkább aquatermolízis) megvizsgáltam, hogy az egyes, kiválasztott szerves anyag típusok jellemzően milyen oldott aromás vegyületeket szolgáltatnak, ezek milyen mennyiségben és arányban jelennek meg a hőkezeléses kísérletek eredményeképpen. Az ebben a fejezetben bemutatott eredmények részben már publikálásra kerültek (Fekete et al., 2012).

A szakirodalomban fellelhető hasonló kísérletek (1. fejezet) többnyire egészen más célokkal készültek (pl. katalizátorok hatása, müanyagok bomlásának vizsgálata stb), így magát a módszert is ki kellett dolgoznom. Csak az első sorozatok után alakult ki a megfelelő módszer, a hőmérsékleteket, mintamennyiségeket és a hőkezelés idejét illetően. A kísérletekhez használt természetes kiindulási anyagokat és a módszert a 2.2 részben tárgyalom részletesen. A továbbiakban az oxidatív (lásd 2.2) körülmények között végzett, bevezető kísérletek eredményeit tárgyalom külön, illetve a reduktív viszonyok között végzett kísérletek eredményeit részekre bontva (vak mérések, fenol termékei, illetve alkilbenzolok, PAH-ok, heteroaromás vegyületek és fenolok a vizsgált kísérleti anyagokban) mutatom be.

A részletes eredményeket a Függelékben adom meg, míg a szövegben található táblázatokban az alábbiak szerint összevont vegyületcsoportok értékeit mutatom be.

Az értelmezés során összevontam a vizsgált vegyületeket a metil-, illetve alkilcsoportok száma és hossza szerint a következőképpen: benzol, toluol, C2 (xilolok, etilbenzol, sztirol), C3 (izopropilbenzol, n-propilbenzol, 1-etil-2-metilbenzol, 1-etil-3-metilbenzol, 1-etil-4metilbenzol, 1,2,3-trimetilbenzol, 1,2,4-trimetilbenzol, 1,3,5-trimetilbenzol) és C4+ (tercbutilbenzol, szek-butilbenzol, 1-izopropil-4-metilbenzol, 1,3-dietilbenzol, 1,4-dietilbenzol, nbutilbenzol). 
A policiklikus aromás szénhidrogéneket az alkilbenzolokhoz hasonlóan csoportokba gyüjtöttem, a gyürük száma szerint: O2 (naftalinok), O3 (acenaftilén, acenaftén, fluorén, fenantrén, antracén) és O4+ (fluorantén, pyrén, benzo(a)antracén, krizén, benzo(b)fluorantén, benzo(k)fluorantén, benz(a)pirén, indeno(1,2,3,cd)pirén, dibenzo(a,h)antracén, benzo(g,h,i)perilén).

A fenolok esetében az alkilbenzolokhoz hasonló módszert alkalmaztam: fenol, F1 (2metilfenol, 3-metilfenol, 4-metilfenol), F2 (2,6-dimetilfenol, 2-etilfenol, 2,4-dimetilfenol, 2,5dimetilfenol, 4-etilfenol, 3,5-dimetilfenol, 2,3-dimetilfenol, 3,4-dimetilfenol), F3 (2izopropilfenol, 2,3,5-trimetilfenol). Egyedül a fenol kontrollanyag vizsgálatánál mutatom be nem csoportosítva az eredményeket.

A heteroaromás vegyületek relatív koncentrációit az illó aromásokról készült SCAN GC/MS felvételek totálion kromatogramjaiból számítottam ki, a görbe alatti terület százalékos arányait alapul véve. Ennek megfelelően a kapott eredmények csak arányokban értelmezhetők, így is kezelem ezeket a vonatkozó fejezetben. Az N-, S-, O-tartalmú aromás vegyületek esetében mindig összeadtam az adott heteroatomot tartalmazó minden aromás vegyületet, legyen az egy vagy két gyürüs, illetve adott esetben valamilyen alkil homológ.

\subsection{Felmérő kísérletek, oxidatív körülmények között}

A FA, HA és SZÉN mintákon készültek ilyen módszerrel kísérletek. Az „oxidatív körülmények" ebben az esetben azt jelenti, hogy reaktor gőzterében levegőt hagytam és a vízben is az eredetileg oldott oxigén maradt. Kezdetben 25 (FAo, HAo), majd 50 mg (SZÉNo) mintával dolgoztam (1. táblázat).

\begin{tabular}{|lcccccccc|}
\hline Minta & benzol & toluol & $\mathrm{C} 2$ & $\mathrm{C} 3$ & $\mathrm{C} 4+$ & $\mathrm{O} 2$ & O3 & O4+ \\
\hline FAo $150^{\circ} \mathrm{C}$ & 0,0 & 0,0 & 0,0 & 0,0 & 0,0 & 0 & 5 & 1 \\
FAo $200^{\circ} \mathrm{C}$ & 0,0 & 0,0 & 0,0 & 0,0 & 0,0 & 0 & 14 & 2 \\
FAo $250^{\circ} \mathrm{C}$ & 1,0 & 0,2 & 0,0 & 0,0 & 0,0 & 0 & 16 & 2 \\
FAo $300^{\circ} \mathrm{C}$ & 5,7 & 0,1 & 0,0 & 0,0 & 0,0 & 0 & 29 & 2 \\
\hline HAo $220^{\circ} \mathrm{C}$ & 0,2 & 0,1 & 0,0 & 0,0 & 0,0 & 15 & 27 & 2 \\
HAo $250^{\circ} \mathrm{C}$ & 0,4 & 0,4 & 0,0 & 0,0 & 0,0 & 1 & 11 & 1 \\
HAo $300^{\circ} \mathrm{C}$ & 2,5 & 0,2 & 0,0 & 0,0 & 0,0 & 16 & 28 & 2 \\
\hline SZÉNo $220^{\circ} \mathrm{C}$ & 3,1 & 0,9 & 0,4 & 0,2 & 0,0 & 14 & 30 & 1 \\
SZÉNo $250^{\circ} \mathrm{C}$ & 1,7 & 0,3 & 0,0 & 0,0 & 0,0 & 13 & 40 & 1 \\
SZÉNo $300^{\circ} \mathrm{C}$ & 9,2 & 0,1 & 0,0 & 0,0 & 0,0 & 10 & 36 & 1 \\
\hline
\end{tabular}

1. táblázat. Az oxidatív kísérletek eredményei (vegyületcsoportok, $\mu \mathrm{g} / \mathrm{l}$ ). 
Oxidatív körülmények között egyértelműen a benzol az uralkodó illó aromás vegyület a termékekben. $200^{\circ} \mathrm{C}$ felett jelenik meg, mennyisége $250^{\circ} \mathrm{C}$ felett nő, és nagyságrendileg összevethető a reduktív kísérletekben keletkezett mennyiséggel. Toluol is megfigyelhető, koncentrációja az emelkedő hőmérséklettel csökken. A benzol/toluol arány az oxidatív kísérletekben rendkívül magas, C2, és C3 vegyületek a $220^{\circ} \mathrm{C}$-os SZÉNo mintában megjelennek, máshol nem. A tiofén mennyisége a FAo-ban a legkisebb, és $250^{\circ} \mathrm{C}$ felett a humin anyagokból eltünik, a szénben 0,1-re esik le.

A policiklikus aromás szénhidrogének eloszlása mintánként meglehetősen eltérő. A FAo kísérletekben nem keletkeznek naftalinok (naftalin, 1-metilnaftalin és 2-metilnaftalin). Uralkodó PAH vegyület a hőmérséklettel növekvő koncentrációban jelen levő fenantrén $(\mathrm{O} 3)$, illetve többé-kevésbé állandó mennyiségben található fluorantén és pirén $(\mathrm{O} 4)$. Fluorén csak $300^{\circ} \mathrm{C}$-on jelenik meg a vízben.

A HAo mintában többféle PAH jelenik meg, és nagyobb mennyiségben, mint a FAo-kban. A fluorantén és pirén mennyisége az emelkedő hőmérséklet mellett szintén nagyjából stagnál. A többi vegyület $(\mathrm{O} 2$ és $\mathrm{O} 3)$ mennyisége $220^{\circ} \mathrm{C}$ és $300^{\circ} \mathrm{C}$-on nagyjából egyenlő, $250^{\circ} \mathrm{C}$-on lecsökken. Meg kell jegyezni, hogy a mérési eredmény a fluorantén és pirén értékek nélkül mérési hibának tűnne, de ezeket vizsgálva elfogadható és megmagyarázható. A fenantrén mennyisége a többi PAH-hoz viszonyítva kiemelkedő. Ez azt mutatja, hogy a fenantrén nem érzékeny annyira az oxidációra a vizsgálati körülmények között, mint a többi poliaromás vegyület

A SZÉNo kísérletekben szintén többféle PAH jelenik meg, a HAo-hoz hasonló koncentrációban. Az összes PAH koncentrációja majdnem egyenlő 220 és $300^{\circ} \mathrm{C}$-on, míg a $250^{\circ} \mathrm{C}$-os kísérletben kissé nagyobb. A fluorantén és pirén mennyisége állandó, a naftalinok mennyisége $250^{\circ} \mathrm{C}$-ig állandó, $300^{\circ} \mathrm{C}$-on kissé csökken. A fenantrén az uralkodó $\mathrm{PAH}$, mennyisége $250^{\circ} \mathrm{C}$-on a legnagyobb. Lényeges megjegyezni, hogy antracén oxidatív körülmények között nem jelenik meg, és a $320^{\circ} \mathrm{C}$-os kísérletben (ilyen csak a SZÉN-böl készült) a PAH vegyületek eltünnek.

$\mathrm{Az}$ eredmények alapján kijelenthetjük, hogy az oxigén jelenléte kedvez a nagyméretü molekulák PAH-á alakulásának vagy bomlásának, míg a polikondenzáció jelentősége kicsi, amit mutat az $\mathrm{O} 4+$ vegyületek kis mennyisége is. A legnagyobb hőmérsékleten azonban a molekulák instabillá válnak és eltünnek.

Oxidatív körülmények között a tiofén koncentrációja 0,2 alatti, egyéb heteroaromások és fenolok nem jelennek meg mérhető mennyiségben. 


\subsection{Kísérletek reduktív körülmények között}

\subsubsection{Vak mérések}

A vak méréseknél alkalmazott metódus teljesen megegyezett a kísérleti részben leírtakkal. Csak a reduktív módszert alkalmaztam, 24 órás hőkezelések során. Kétféle vak mérés készült: csak nátrium-hidrogénkarbonátos vízböl (VAK), és $\mathrm{NaHCO}_{3}$-os vízből redukálószerrel (50 mg aszkorbinsavat, „C”). Az eredmények az 2. táblázatban láthatók.

A vak mérésekben az illók aromások mennyisége elhanyagolható. A PAH-ok közül a fenantrén az uralkodó vegyület, akárcsak az oxidatív kísérletekben. Eredete a vak mérésben csak szennyeződés lehet, a reaktor falán visszamaradt csekély mennyiségü kísérleti anyag terméke. Mennyisége azonban jóval elmarad a következőkben bemutatott, valódi prekurzor anyaggal végzett kísérletekben mérttől.

\begin{tabular}{|lcccccccc|}
\hline Minta & benzol & toluol & $\mathrm{C} 2$ & $\mathrm{C} 3$ & $\mathrm{C} 4+$ & $\mathrm{O} 2$ & $\mathrm{O} 3$ & $\mathrm{O} 4+$ \\
\hline VAK $220^{\circ} \mathrm{C}$ & 0 & 0 & 0 & 0 & 0 & 0 & 0 & 0 \\
$\mathrm{VAK} 250^{\circ} \mathrm{C}$ & 0 & 0 & 0 & 0 & 0 & 0 & 0 & 0 \\
$\mathrm{VAK} 300^{\circ} \mathrm{C}$ & 0,3 & 0,1 & 0 & 0 & 0 & 0,8 & 3,1 & 0,7 \\
\hline $\mathrm{C} 220^{\circ} \mathrm{C}$ & 0,1 & 0,3 & 0 & 0 & 0 & 0,7 & 0,5 & 0,1 \\
$\mathrm{C} 250^{\circ} \mathrm{C}$ & 0,2 & 0,4 & 0 & 0 & 0 & 0,5 & 0,6 & 0,2 \\
$\mathrm{C} 300^{\circ} \mathrm{C}$ & 0,5 & 0,7 & 0 & 0,1 & 0 & 1,9 & 3,9 & 1,6 \\
$\mathrm{C} 320^{\circ} \mathrm{C}$ & 2,1 & 1 & 0,9 & 0,4 & 0 & 4,2 & 9,7 & 2,7 \\
\hline
\end{tabular}

2. táblázat. Vak kísérletek alkilbenzol és PAH eredményei (vegyületcsoportok).

Heteroaromás vegyületek nem jelennek meg a kromatogramokban.

Mivel a vak mérések több kísérleti anyaggal folytatott hőkezelés után készültek, megállapítható, hogy az eredmények értékelését a kísérleti módszer nem befolyásolja (azaz nem számítunk jelentős visszamaradt szennyeződésre).

Az aszkorbinsavval végzett kísérletek alapján az illó aromások mennyiségét a használt redukálószer alapvetően nem befolyásolja. A C mintákon és a valódi kísérleti anyagokon mért koncentrációk között az eltérés legalább egy, több esetben két nagyságrendnyi.

A PAH-ok esetében az értelmezés során az aszkorbinsavból keletkezett anyagok mennyiségét a CSAP minták és az O4+ vegyületek esetében figyelembe kell venni, ezt a PAH-oknál tárgyalom. 
Heteroaromás vegyületek közül a várható oxigéntartalmú vegyületek (furánok, benzo- és dibenzofuránok) közül $220^{\circ} \mathrm{C}$-on egy sem, $250^{\circ} \mathrm{C}$-on benzofurán $(3,53), 300^{\circ} \mathrm{C}$-on benzofurán $(3,23)$ és 2-metilbenzofurán $(2,69), 320^{\circ} \mathrm{C}$-on benzofurán $(2,72)$ és 2-metilbenzofurán $(4,87)$ jelenik meg. A zárójeles számok a kromatogram teljes görbe alatti terület százalékát jelentik. Mivel azonban a csúcsok mérete nagyon kicsi, a kísérletekben ezek a mennyiségek nem befolyásolják az eredményeket. Ezt az is mutatja, hogy az $\mathrm{O}$ tartalmú aromások aránya 0-ra is csökkenhet az egyes mintákban, annak ellenére, hogy ugyanúgy tartalmaznak aszkorbinsavat. Fenolok sem a VAK, sem a C mérések esetében nem jelennek meg kimutatható mennyiségben.

\subsubsection{Fenol mérések}

Mivel a hévizekben fontos vizsgálandó vegyületek a fenolok, tájékozódás céljából kísérleteket

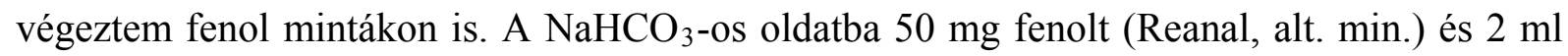
metanolt (Reanal, alt. min.) tettem, aszkorbinsav mellett (50 mg). Mivel ebben az esetben nem állnak rendelkezésre nagyméretü prekurzor molekulák, feltételeztem, hogy az aromatizáció és a hőbomlás lehet a fő folyamat. 24 órás kísérleteket végeztem, annak érdekében, hogy a képződő vegyületek hőstabilitását vizsgáljam. Az eredmények a 3. és 4. táblázatban láthatók.

\begin{tabular}{|lcccccccc|}
\hline Minta & benzol & toluol & $\mathrm{C} 2$ & $\mathrm{C} 3$ & $\mathrm{C} 4+$ & $\mathrm{O} 2$ & $\mathrm{O} 3$ & $\mathrm{O} 4+$ \\
\hline $\mathrm{FM} 220^{\circ} \mathrm{C}$ & 0 & 0 & 13 & 0,2 & 0 & 26 & 29 & 2,6 \\
$\mathrm{FM} 250^{\circ} \mathrm{C}$ & 0 & 0 & 11 & 0,4 & 0 & 24 & 30 & 2,8 \\
$\mathrm{FM} 300^{\circ} \mathrm{C}$ & 0,3 & 0,1 & 14 & 1,1 & 0 & 205 & 41 & 2,7 \\
$\mathrm{FM} 320^{\circ} \mathrm{C}$ & 0,1 & 0,3 & 19 & 1,5 & 0,1 & 4,7 & 10 & 2,3 \\
\hline
\end{tabular}

3. táblázat. Fenol kísérletek alkilbenzol és PAH eredményei (vegyületcsoportok, $\mu g / l)$.

A tiofén jelenléte arra utal, hogy minimális mennyiségű szennyező mindig marad vissza a reaktorban, ám ennek mennyisége a mintákhoz képest elhanyagolható. A C2 és a dimetilfenolok nagy relatív mennyisége azt mutatja, hogy a fenol hajlamos metileződni, legalábbis metanol és aszkorbinsav jelenlétében. 


\begin{tabular}{|c|c|c|c|c|c|c|c|c|c|c|c|c|c|}
\hline Minta & 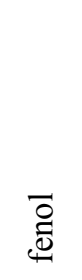 & 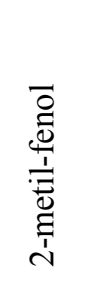 & 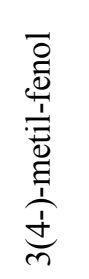 & 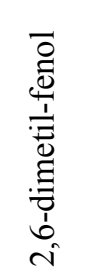 & $\begin{array}{l}\overrightarrow{0} \\
\stackrel{0}{0} \\
\stackrel{d}{1} \\
\overrightarrow{0} \\
\dot{0} \\
\sim\end{array}$ & 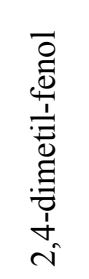 & 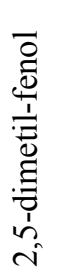 & 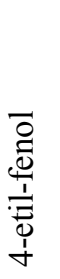 & 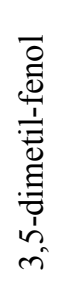 & 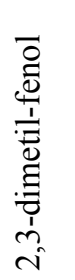 & 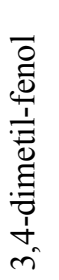 & 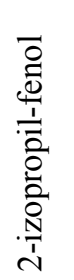 & 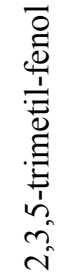 \\
\hline $\mathrm{FM} 220^{\circ} \mathrm{C}$ & 0,03 & 0 & 0 & 0 & 0 & 0 & 0 & 0 & 0 & 0 & 0 & 0 & 0 \\
\hline $\mathrm{FM} 250^{\circ} \mathrm{C}$ & 0,14 & 0,03 & 0,01 & 0 & 0 & 0 & 0 & 0 & 0 & 0 & 0 & 0 & 0 \\
\hline $\mathrm{FM} 300^{\circ} \mathrm{C}$ & 0,15 & 0,49 & 0,43 & 0,26 & 0 & 1,94 & 0 & 0 & 0 & 0 & 0 & 0 & 0 \\
\hline $\mathrm{FM} 320^{\circ} \mathrm{C}$ & 0,09 & 0,72 & 0,6 & 1,34 & 0,01 & 8,08 & 0 & 0 & 0 & 0 & 0 & 0 & 0,01 \\
\hline
\end{tabular}

4. táblázat. Fenol kísérletek fenol eredményei (vegyületcsoportok, $m g / l$ ).

Nem meglepö, hogy nagy mennyiségben jelennek meg PAH-ok, főleg naftalinok. Ez az irodalmi adatok alapján is várható cikloaddíciós és aromatizációs reakciók és az aromatizáció müködését mutatja $300^{\circ} \mathrm{C}$-ig. Ezt támasztja alá, hogy az O3 és O4 vegyületek szintén a VAK és $\mathrm{C}$ kísérletekben kimutatottól nagyobb koncentrációban mérhetők.

$300^{\circ} \mathrm{C}$ és $320^{\circ} \mathrm{C}$ között egyértelmüen uralkodóvá válik a képződött vegyületek lebomlása. Csak a toluol, a C2 vegyületek és a fenolok mutatnak növekedést, tehát azok, amik a fenolból (és metanolból) közvetlenül utánpótlódnak. Ez jó bizonyítéka lehet annak, hogy $\sim 300^{\circ} \mathrm{C}$-ig jellemző a nagyobb molekulák kisebbekből történő képződése, míg e hőmérséklet felett csak a megfelelő prekurzorral rendelkező molekulák koncentrációja nő, tehát a bomlási reakciók intenzívebbé válnak.

Meg kell azonban jegyezni, hogy ugyanilyen eredménnyel járhat a polikondenzáció/aromatizáció hirtelen intenzívebbé válása, amit - ha nem túl erőteljesen is, de - alátámaszt három megfigyelés: az alkilbenzolok mennyiségének kvázi stagnálása az emelkedő hőmérséklettel, a benzol megjelenése $300^{\circ} \mathrm{C}$-on, majd csökkenése $320^{\circ} \mathrm{C}$-on és a többgyürüs vegyületek arányának jelentős növekedése $\left(300^{\circ} \mathrm{C}: \mathrm{O} 3 / \mathrm{O} 2=0,2\right.$ és $\mathrm{O} 4+/ \mathrm{O} 2=0,01$; majd $\left.320^{\circ} \mathrm{C}: \mathrm{O} 3 / \mathrm{O} 2=2,13, \mathrm{O} 4+/ \mathrm{O} 2=0,49\right)$ azzal együtt, hogy mennyiségük csökken, valószínüleg a molekulatömeg növekedésével oldhatatlanná válnak és/vagy eltünnek a mért tartományból. 


\subsubsection{Benzol és alkilbenzolok a kísérleti anyagokban}

A reduktív hökezelések során alkilbenzol homológok nagy mennyiségben keletkeznek (5. táblázat).

\begin{tabular}{|c|c|c|c|c|c|c|c|c|c|c|}
\hline Minta & 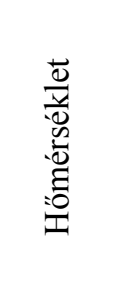 & $\begin{array}{l}\overline{8} \\
\text { D. } \\
\end{array}$ & $\begin{array}{l}\bar{O} \\
\stackrel{0}{9}\end{array}$ & U & $\tilde{U}$ & 寺 & 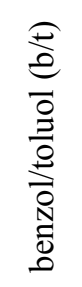 & 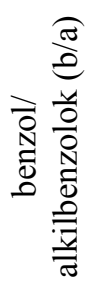 & 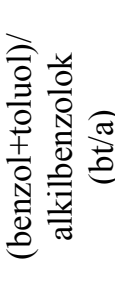 & 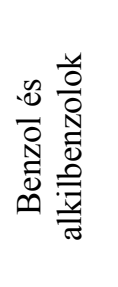 \\
\hline \multirow{4}{*}{$\underset{\sim}{\mathbb{N}}$} & $220^{\circ} \mathrm{C}$ & 3,4 & 1,3 & 1,3 & 0,3 & 0,0 & 2,62 & 1,17 & 2,94 & 6,3 \\
\hline & $250^{\circ} \mathrm{C}$ & 1,7 & 1,8 & 0,8 & 0,2 & 0,0 & 0,94 & 0,61 & 3,50 & 4,5 \\
\hline & $300^{\circ} \mathrm{C}$ & 8,4 & 10,2 & 9,2 & 5,2 & 0,4 & 0,82 & 0,34 & 1,26 & 33,4 \\
\hline & $320^{\circ} \mathrm{C}$ & 13,0 & 18,3 & 15,7 & 9,0 & 0,6 & 0,71 & 0,30 & 1,24 & 56,6 \\
\hline \multirow{4}{*}{$\stackrel{\ominus}{\oplus}$} & $220^{\circ} \mathrm{C}$ & 1,6 & 0,7 & 1,6 & 0,7 & 0,1 & 2,29 & 0,52 & 0,96 & 4,7 \\
\hline & $250^{\circ} \mathrm{C}$ & 4,5 & 4,1 & 7,3 & 4,8 & 0,4 & 1,10 & 0,27 & 0,69 & 21,1 \\
\hline & $300^{\circ} \mathrm{C}$ & 6,6 & 21,7 & 34,4 & 34,3 & 2,8 & 0,30 & 0,07 & 0,40 & 99,8 \\
\hline & $320^{\circ} \mathrm{C}$ & 13,1 & 22,6 & 51,2 & 51,6 & 4,9 & 0,58 & 0,10 & 0,33 & 143,4 \\
\hline \multirow{4}{*}{ 密 } & $220^{\circ} \mathrm{C}$ & 0,8 & 6,8 & 32,6 & 0,0 & 0,1 & 0,12 & 0,02 & 0,23 & 40,3 \\
\hline & $250^{\circ} \mathrm{C}$ & 1,4 & 56,9 & 184,1 & 0,0 & 0,1 & 0,02 & 0,01 & 0,32 & 242,5 \\
\hline & $300^{\circ} \mathrm{C}$ & 3,3 & 94,8 & 136,8 & 2,2 & 0,4 & 0,03 & 0,01 & 0,70 & 237,5 \\
\hline & $320^{\circ} \mathrm{C}$ & 12,6 & 115,9 & 140,3 & 4,2 & 0,5 & 0,11 & 0,05 & 0,89 & 273,5 \\
\hline \multirow{4}{*}{ 左 } & $220^{\circ} \mathrm{C}$ & 0,6 & 1,9 & 4,6 & 0,2 & 0 & 0,08 & 0,34 & 0,32 & 7,3 \\
\hline & $250^{\circ} \mathrm{C}$ & 1,1 & 9,1 & 13,2 & 0,5 & 0 & 0,05 & 0,43 & 0,12 & 23,9 \\
\hline & $300^{\circ} \mathrm{C}$ & 61,8 & 60 & 53,9 & 13,6 & 1,5 & 0,32 & 0,64 & 1,03 & 190,8 \\
\hline & $320^{\circ} \mathrm{C}$ & 355,9 & 98,7 & 89,8 & 32,4 & 1,6 & 0,62 & 0,79 & 3,61 & 578,4 \\
\hline \multirow{4}{*}{ 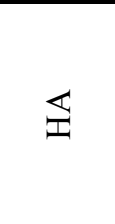 } & $220^{\circ} \mathrm{C}$ & 1,2 & 2,9 & 20,4 & 1,7 & 0,4 & 0,05 & 0,15 & 0,41 & 26,6 \\
\hline & $250^{\circ} \mathrm{C}$ & 2,5 & 19,6 & 68,6 & 3,4 & 0,3 & 0,03 & 0,23 & 0,13 & 94,4 \\
\hline & $300^{\circ} \mathrm{C}$ & 7,9 & 77,5 & 113,7 & 16,5 & 2,6 & 0,04 & 0,39 & 0,1 & 218,2 \\
\hline & $320^{\circ} \mathrm{C}$ & 15,5 & 76,5 & 91,7 & 23,2 & 3,7 & 0,07 & 0,44 & 0,2 & 210,6 \\
\hline \multirow{4}{*}{ 死 } & $220^{\circ} \mathrm{C}$ & 0,8 & 0,9 & 2,3 & 1,3 & 0 & 0,15 & 0,32 & 0,89 & 5,3 \\
\hline & $250^{\circ} \mathrm{C}$ & 6,3 & 29,2 & 33 & 29,6 & 0,4 & 0,06 & 0,36 & 0,22 & 98,5 \\
\hline & $300^{\circ} \mathrm{C}$ & 13,6 & 32,8 & 34,2 & 28,2 & 0,7 & 0,12 & 0,42 & 0,42 & 109,5 \\
\hline & $320^{\circ} \mathrm{C}$ & 37,2 & 82 & 92,4 & 58,6 & 1,3 & 0,14 & 0,44 & 0,45 & 271,5 \\
\hline \multirow{4}{*}{ 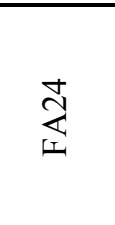 } & $220^{\circ} \mathrm{C}$ & 0,6 & 1,3 & 5,7 & 0,8 & 0 & 0,07 & 0,23 & 0,46 & 8,4 \\
\hline & $250^{\circ} \mathrm{C}$ & 0,9 & 7 & 30,6 & 1,7 & 0,1 & 0,02 & 0,2 & 0,13 & 40,3 \\
\hline & $300^{\circ} \mathrm{C}$ & 16,8 & 31,5 & 58,9 & 7,8 & 0,8 & 0,15 & 0,42 & 0,53 & 115,8 \\
\hline & $320^{\circ} \mathrm{C}$ & 99,6 & 47,9 & 85,6 & 17,5 & 1,9 & 0,39 & 0,58 & 2,08 & 252,5 \\
\hline
\end{tabular}

5. táblázat. Benzol és alkilbenzol vegyületcsoportok koncentrációja ( $\mu g / l)$ és mutatók. 
Az alkilláncok hossza és eloszlása változatos. A koncentrációk már kis hőmérsékleten is jóval nagyobbak, mint az oxidativ kísérletekben. Az eredmények azt mutatják, hogy ezek a kísérleti körülmények jobban megfelelnek a természeti folyamatoknak.

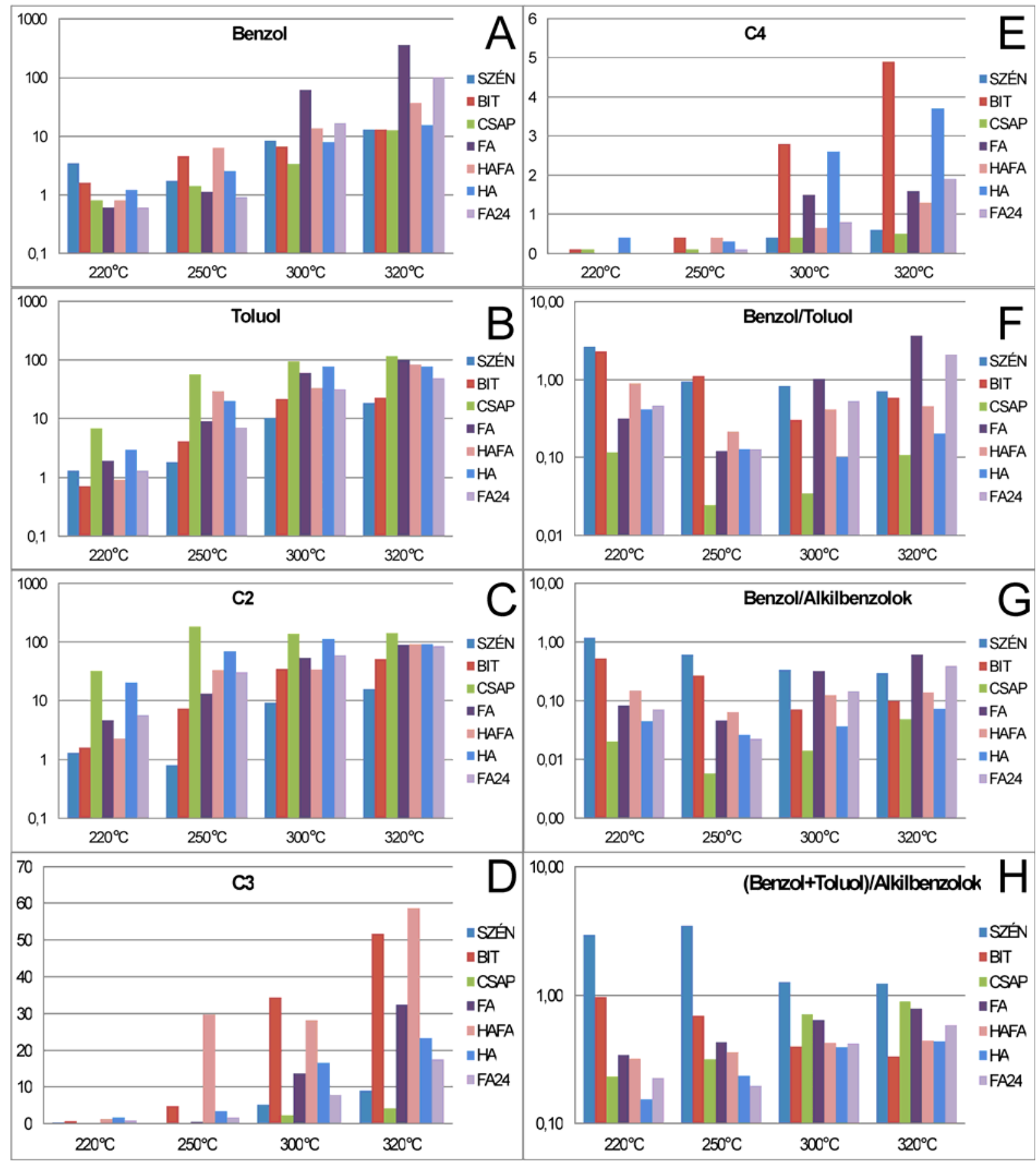

2. ábra. A benzol és alkilbenzolok eloszlása ( $\mu \mathrm{g} / l)$ és mutatók a kísérletekben. A: benzol, B: toluol, C: C2 vegyületek, $D$ : C3 vegyületek, $E$ : C4 vegyületek, $F$ : benzol/toluol; $G$ : benzol/összes alkilbenzol; H: (benzol+toluol)/összes alkilbenzol. 
A hőmérséklet emelkedésével a benzol koncentráció minden esetben növekszik (2A. ábra). A SZÉN mintában a legkisebb érték $250^{\circ} \mathrm{C}$-on látható, de a növekedés $320^{\circ} \mathrm{C}$-ig folyamatos. A benzol koncentráció a FA mintában $300^{\circ} \mathrm{C}$ és $320^{\circ} \mathrm{C}$-on különösen nagy.

A benzolhoz hasonlóan a toluol koncentrációja is növekszik az emelkedő hőmérséklettel (12. 2B. ábra). A CSAP termeli a legtöbb toluolt minden hőmérsékleten, a SZÉN és BIT minták a legkevesebbet.

A benzol/alkilbenzolok (b/a) arány $250^{\circ} \mathrm{C}$-ig csökken, nagyobb hőmérsékleten növekszik a FA, HAFA, HA és CSAP minták esetében (2G. ábra), míg ezekben a (benzol+toluol)/alkilbenzolok arány (bt/a) folyamatosan nő a hőmérséklet emelésével, aminek oka a rendkívül erőteljes benzol- (HA, HAFA, HA), illetve a toluolképződés (CSAP; 2H. ábra). A SZÉN és BIT mintákban - a többitől eltérően - mindkét mutató kis kilengéssel (SZÉN bt $/ \mathrm{a}, 250^{\circ} \mathrm{C}$, illetve BIT b/a $320^{\circ} \mathrm{C}$ ) csökken.

A benzol/toluol arány (b/t) a SZÉN mintában végig, a BIT-ben $300^{\circ} \mathrm{C}$-ig csökken, a többi mintában $250^{\circ} \mathrm{C}$-ig csökken, majd $320^{\circ} \mathrm{C}$-ig nő $(2 \mathrm{~F})$.

Rendkívül nagy eltérések tapasztalhatók a minták között a C2 koncentrációk esetében, föleg kisebb hőmérsékleteken. A CSAP minták kiugróan sok, míg a SZÉN és BIT minták meglehetősen kevés C2 alkilbenzolokat termelnek (2C. ábra). A huminanyagok közül a toluolhoz hasonlóan a HA termeli a legtöbb C2 vegyületet. $250^{\circ} \mathrm{C}$-on a SZÉN minimum, míg a CSAP maximum értéket mutat.

Eltérő a kép a C3 és C4+ vegyületek esetében (2D-E. ábra). Leginkább szembetünő az, hogy a CSAP termeli a legkevesebb C3 és a SZÉN-nel együtt a legkevesebb C4+ vegyületet. A BITböl $300^{\circ} \mathrm{C}$ és $320^{\circ} \mathrm{C}$-on a HAFA-hoz hasonlóan kiugróan sok $\mathrm{C} 3$ alkilbenzol keletkezik. A BIT a C4+ vegyületek esetében is a legnagyobb értékekkel bír $220^{\circ} \mathrm{C}$ felett, míg a SZÉN-ből és a CSAP-ból keletkezik a legkevesebb C3 ésC4+. Huminanyagok közül a C3 vegyületek esetében a HAFA, C4+ esetében a HA a legnagyobb termelő.

Megjegyzésre érdemes, hogy a HAFA kísérletekben képződött benzol és alkilbenzolok mennyisége nem esik a HA és a FA kísérletekben mértek közé, ahogy ez esetleg várható lenne. Ez mégsem meglepő, ha figyelembe vesszük, hogy a kiindulási anyagok - bár elválasztástechnikailag rokon anyagok - alapvetően eltérö környezetből származnak (a HA és a FA felszín közelből, míg a HAFA forró, nagy mélységből származó hévízből), és így az összetétel és szerkezetbeli eltérések jelentősek köztük.

A FA prekurzor anyagból rövidebb, 24 órás szimulációs kísérleteket is végeztem. Az eredmények FA24 néven szerepelnek a megfelelő ábrákon. Egyszerü nem-egyensúlyi vagy lassan végbemenő kémiai reakciók esetében az azonos hőmérsékleten rövidebb ideig végzett 
hökezelés várhatóan azt eredményezi, hogy a keletkező anyagok kisebb koncentrációban jelennek majd meg. Ezzel ellentétben az figyelhető meg, hogy bizonyos vegyületek a rövid kísérletekben határozottan nagyobb koncentrációban találhatók meg, mint a 72 órásokban: $\mathrm{C} 2$ vegyületek $220^{\circ} \mathrm{C}, 250^{\circ} \mathrm{C}$ és $300^{\circ} \mathrm{C}$-on, a $\mathrm{C} 3$ vegyületek $220^{\circ} \mathrm{C}$ és $250^{\circ} \mathrm{C}$-on, és a $\mathrm{C} 4$ vegyületek $250^{\circ} \mathrm{C}$ és $320^{\circ} \mathrm{C}$-on. Meg kell jegyeznem, hogy a $\mathrm{C} 4$ esetében a különbségek nagyon kicsik. A b/a mutató csökkenése $250^{\circ} \mathrm{C}$-on a FA24 esetében is jellemző.

Ha az összegzett benzol és alkilbenzol tartalmat (3. ábra) tekintjük (benzol+toluol $+\mathrm{C} 2+\mathrm{C} 3+\mathrm{C} 4)$, megfigyelhetö, hogy a kisebb hőmérsékleteken $\left(220^{\circ} \mathrm{C}\right.$ és $250^{\circ} \mathrm{C}$ ) a CSAP-ból, HA-ból és a HAFA-ból, $320^{\circ} \mathrm{C}$-on pedig a FA-ból keletkezik a legtöbb illó aromás vegyület. A termékek koncentrációja folyamatosan nő a magasabb hőmérséklet felé haladva, kivéve a kisebb csökkenést ( $\sim$ stagnálást) a HA esetében $320^{\circ} \mathrm{C}$-on és a minimum értéket a SZÉN esetében $250^{\circ} \mathrm{C}$-on. A rövidebb kísérletekben is viszonylag sok vegyület keletkezik, a 72 órás kezelésekkel összevethető mennyiségben. A legkevesebb alkilbenzolt $250^{\circ} \mathrm{C}$-tól felfelé a SZÉN termeli.

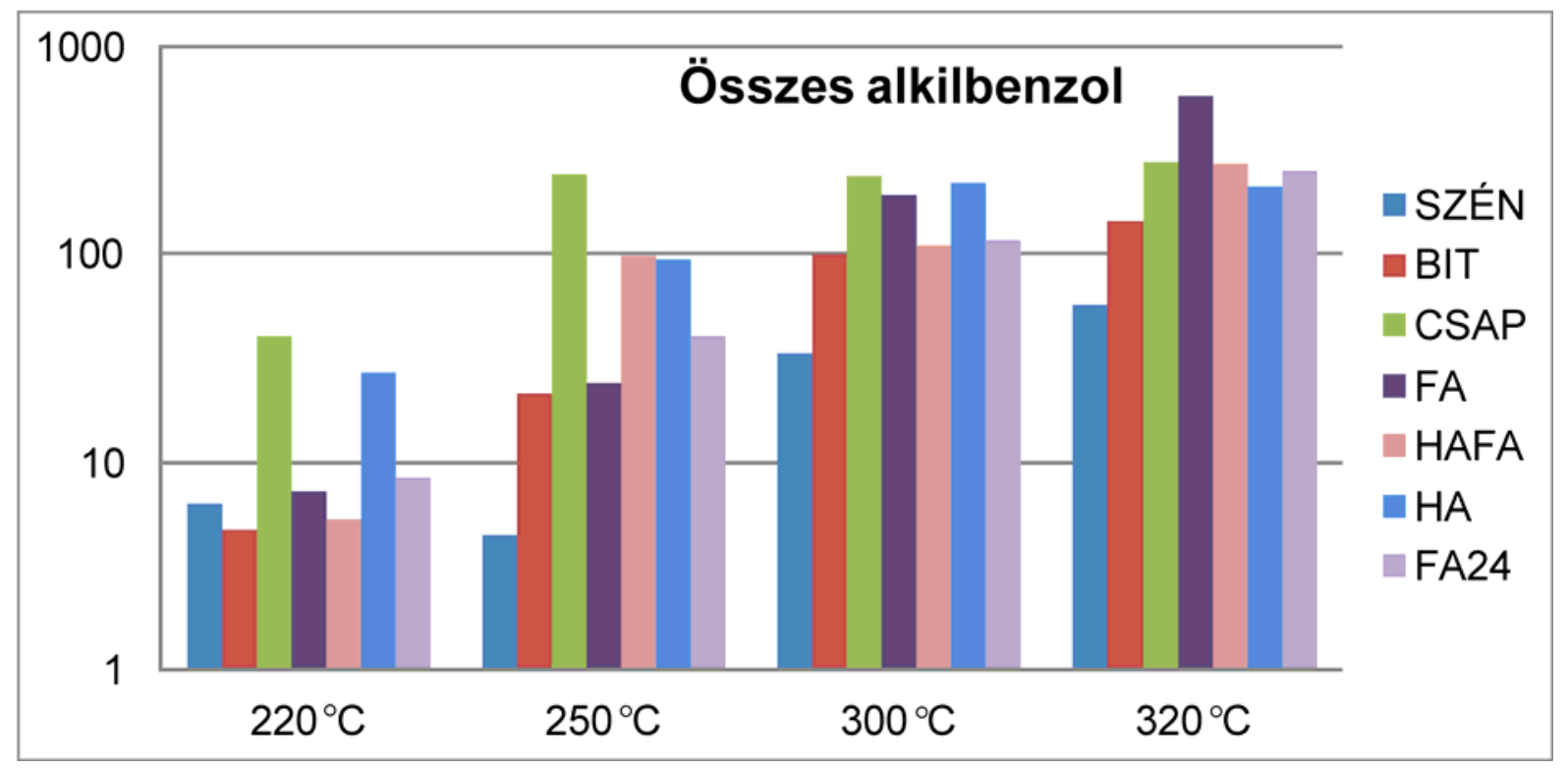

3. ábra. Az összes alkilbenzol koncentrációk ( $\mu g / l)$ a kísérletekben. 


\subsubsection{Policiklikus aromás szénhidrogének a kísérleti anyagokban}

Az alkilbenzolokhoz hasonlóan a PAH-ok is nagy mennyiségben jelennek meg a kísérletek során (6. táblázat).

\begin{tabular}{|c|c|c|c|c|c|c|c|c|c|}
\hline & 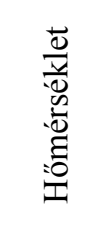 & 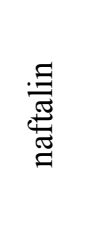 & 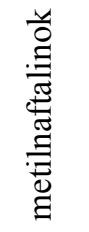 & ชิ & $\tilde{O}$ & $\stackrel{+}{ \pm}$ & 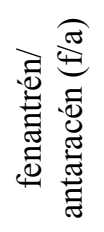 & 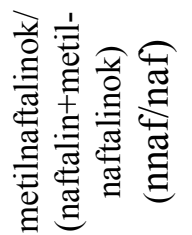 & $\begin{array}{l}\mathbb{J} \\
\mathbb{\Delta} \\
\tilde{D} \\
\mathbb{N} \\
0 \\
: 0\end{array}$ \\
\hline \multirow{4}{*}{$\underset{\text { 咭 }}{\mathrm{Z}}$} & $220^{\circ} \mathrm{C}$ & 4,1 & 12,5 & 16,6 & 23,7 & 3,2 & 40,0 & 0,75 & 43,5 \\
\hline & $250^{\circ} \mathrm{C}$ & 4,2 & 13,7 & 17,9 & 20,8 & 3,4 & 46,7 & 0,77 & 42,1 \\
\hline & $300^{\circ} \mathrm{C}$ & 5,3 & 18,0 & 23,3 & 34,2 & 5,3 & 18,0 & 0,77 & 62,8 \\
\hline & $320^{\circ} \mathrm{C}$ & 10,0 & 28,0 & 38,0 & 51,9 & 6,0 & 6,3 & 0,74 & 95,9 \\
\hline \multirow{4}{*}{$\stackrel{\Xi}{\oplus}$} & $220^{\circ} \mathrm{C}$ & 0,5 & 0,5 & 1,0 & 7,4 & 3,8 & - & 0,50 & 12,2 \\
\hline & $250^{\circ} \mathrm{C}$ & 0,8 & 1,3 & 2,1 & 10,7 & 4,6 & 17,2 & 0,62 & 17,4 \\
\hline & $300^{\circ} \mathrm{C}$ & 3,3 & 8,4 & 11,7 & 15,3 & 4,8 & 9,2 & 0,72 & 31,8 \\
\hline & $320^{\circ} \mathrm{C}$ & 12,2 & 26,9 & 39,1 & 24,4 & 6,0 & 9,1 & 0,69 & 69,5 \\
\hline \multirow{4}{*}{ 离 } & $220^{\circ} \mathrm{C}$ & 0,4 & 0,3 & 0,7 & 0,7 & 1,1 & 3,0 & 0,43 & 2,5 \\
\hline & $250^{\circ} \mathrm{C}$ & 1,1 & 0,9 & 2,0 & 2,5 & 0,9 & 2,5 & 0,45 & 5,4 \\
\hline & $300^{\circ} \mathrm{C}$ & 1,2 & 2,5 & 3,7 & 4,3 & 1,2 & 2,3 & 0,68 & 9,2 \\
\hline & $320^{\circ} \mathrm{C}$ & 4,0 & 6,9 & 10,8 & 9,7 & 2,7 & 1,3 & 0,63 & 23,2 \\
\hline \multirow{4}{*}{$\overleftrightarrow{\Sigma}$} & $220^{\circ} \mathrm{C}$ & 3,1 & 6,5 & 9,6 & 11,3 & 2,7 & 75,0 & 0,68 & 23,6 \\
\hline & $250^{\circ} \mathrm{C}$ & 4,8 & 11,0 & 15,8 & 13,3 & 3,0 & 79,0 & 0,70 & 32,1 \\
\hline & $300^{\circ} \mathrm{C}$ & 7,4 & 15,3 & 22,7 & 24,9 & 4,4 & 9,4 & 0,67 & 52,0 \\
\hline & $320^{\circ} \mathrm{C}$ & 16,7 & 27,4 & 44,1 & 45,5 & 6,6 & 3,4 & 0,62 & 96,2 \\
\hline \multirow{4}{*}{ 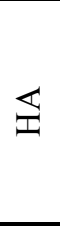 } & $220^{\circ} \mathrm{C}$ & 1,3 & 1,3 & 2,6 & 3,5 & 0,8 & 12,5 & 0,50 & 6,9 \\
\hline & $250^{\circ} \mathrm{C}$ & 1,5 & 2,1 & 3,6 & 2,8 & 0,8 & 8,0 & 0,58 & 7,2 \\
\hline & $300^{\circ} \mathrm{C}$ & 3,6 & 5,2 & 8,8 & 11,0 & 1,9 & 4,2 & 0,59 & 21,7 \\
\hline & $320^{\circ} \mathrm{C}$ & 7,7 & 10,3 & 18,0 & 16,8 & 2,8 & 2,9 & 0,57 & 37,6 \\
\hline \multirow{4}{*}{$\underset{I}{\overleftrightarrow{I}}$} & $220^{\circ} \mathrm{C}$ & 4,8 & 11,1 & 15,9 & 15,6 & 1,4 & 110,0 & 0,70 & 32,9 \\
\hline & $250^{\circ} \mathrm{C}$ & 6,4 & 16,5 & 22,9 & 21,4 & 1,6 & 64,5 & 0,72 & 45,9 \\
\hline & $300^{\circ} \mathrm{C}$ & 12,3 & 26,3 & 38,6 & 78,7 & 3,5 & 20,3 & 0,68 & 120,8 \\
\hline & $320^{\circ} \mathrm{C}$ & 44,3 & 65,4 & 109,7 & 127,4 & 7,4 & 8,2 & 0,60 & 244,5 \\
\hline \multirow{4}{*}{ 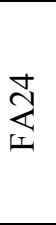 } & $220^{\circ} \mathrm{C}$ & 2,2 & 0,9 & 3,1 & 3,6 & 0,8 & 12,5 & 0,29 & 7,5 \\
\hline & $250^{\circ} \mathrm{C}$ & 1,8 & 0,9 & 2,7 & 4,6 & 1,0 & 14,0 & 0,33 & 8,3 \\
\hline & $300^{\circ} \mathrm{C}$ & 2,2 & 1,1 & 3,3 & 5,3 & 1,2 & 10,8 & 0,33 & 9,8 \\
\hline & $320^{\circ} \mathrm{C}$ & 4,1 & 5,6 & 9,7 & 17,3 & 1,9 & 3,9 & 0,58 & 28,9 \\
\hline
\end{tabular}

6. táblázat. A PAH vegyületcsoportok koncentrációi ( $\mu \mathrm{g} / l)$ és mutatók a kísérletekben.

A PAH-ok mennyisége nő a hőmérséklet emelkedésével minden minta esetében, de a koncentrációk eltérőek. 
Az aszkorbinsavból keletkező PAH-ok miatt az ábrákon (4. ábra) feltüntetem a C mintákban (3.2.1. fejezet) mért mennyiségeket. A SZÉN, FA és HAFA mintákból keletkezik a legtöbb PAH vegyület. A BIT naftalinok esetében $300^{\circ} \mathrm{C}$ és $320^{\circ} \mathrm{C}$-on tapasztalható intenzív termelés, O3 vegyületeket tekintve a negyedik legnagyobb, O4+ esetében pedig a legnagyobb értékek közt van, hőmérséklettől függően. A CSAP hőkezelések során alig keletkezik több PAH, mint a C mintákból. A HA és a rövid FA24 kísérletekből származó PAH-ok koncentrációi hasonlóak, de mindenképp figyelemreméltó, hogy a FA24-ben O4+ vegyületekböl nagy hőmérsékleten kevesebb keletkezik, mint a C-ben.

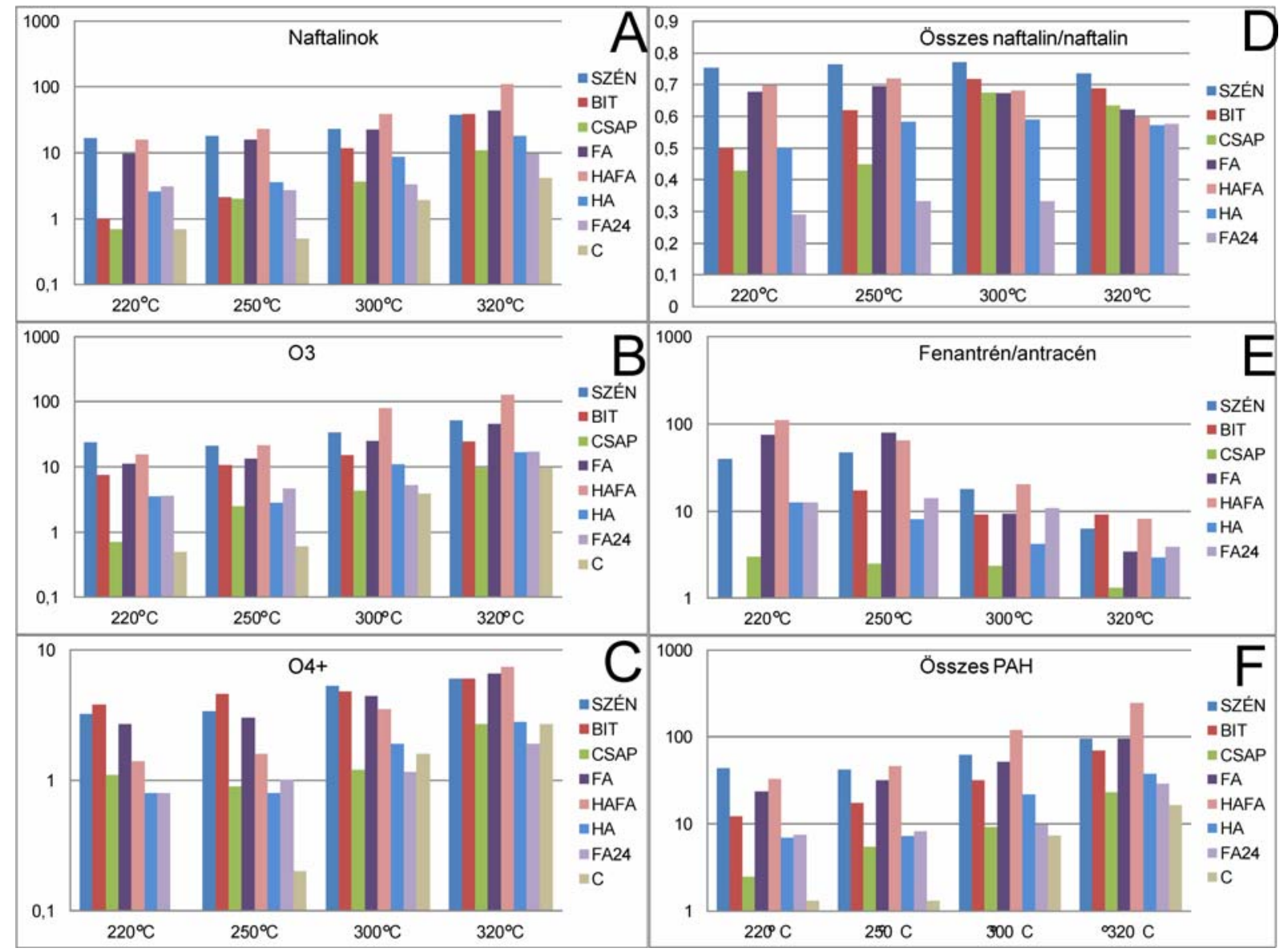

4. ábra. A PAH-ok eloszlása ( $\mu g / l)$ és mutatók a kisérletekben. A: naftalinok (1-metilnaftalin+2-metil-naftalin+naftalin); $B: \quad O 3$ vegyületek; $C: \quad O 4+$ vegyületek; $D$ : naftalinok/naftalin; E: fenatrén/antracén; F: összes PAH koncentráció.

A metilnaftalinok/(naftalin+metilnaftalinok) (mnaf/naf) arányát vizsgálva (4D. ábra) azt látjuk, hogy a kezdetben növekszik, majd nagyobb hőmérsékleten csökken a mutató. A csúcsérték a FA és HAFA esetében $250^{\circ} \mathrm{C}$-nál, a többi minta esetében $300^{\circ} \mathrm{C}$-nál van. A FA24 esetében a növekedés folyamatos az emelkedő hőmérséklettel. 
Az antracén és fenatrén aránya (f/a) a már megfigyelt eltérő érzékenységük miatt érdekes mutató lehet. Valóban, a 4E. ábrán látszik, hogy a mutató nagyon erősen függ a hőmérséklettől, emellett a kísérleti anyag szerkezeti eltéréseit is mutatja. A mutató nagysága nem függ a szerves anyag érettségétől, a fulvosavakban, SZÉN-ben és BIT-ben a keletkező antracén mennyisége elenyésző, míg a HA-ból és CSAP-ból a fenantrénhez képest több van. 


\subsubsection{Heteroaromás vegyületek a kísérleti anyagokban}

A heteroaromás vegyületek reduktív körülmények között - föleg a kis hőmérsékletű kísérletekben - igen jellemző termékek (7. táblázat).

\begin{tabular}{|c|c|c|c|c|c|c|c|c|}
\hline Minta & Hőmérséklet & $\mathrm{N} / \mathrm{NSO}$ & $\mathrm{S} / \mathrm{NSO}$ & $\mathrm{O} / \mathrm{NSO}$ & N/aro & S/aro & $\mathrm{O} /$ aro & $\mathrm{NSO} / \mathrm{aro}$ \\
\hline \multirow{4}{*}{ 疍 } & $220^{\circ} \mathrm{C}$ & 0,00 & 0,76 & 0,24 & 0,00 & 0,77 & 0,24 & 1,01 \\
\hline & $250^{\circ} \mathrm{C}$ & 0,00 & 0,79 & 0,21 & 0,00 & 4,10 & 1,11 & 5,22 \\
\hline & $300^{\circ} \mathrm{C}$ & 0,00 & 0,91 & 0,09 & 0,00 & 1,23 & 0,12 & 1,35 \\
\hline & $320^{\circ} \mathrm{C}$ & 0,00 & 1,00 & 0,00 & 0,00 & 0,72 & 0,00 & 0,72 \\
\hline \multirow{4}{*}{$\underline{\bar{m}}$} & $220^{\circ} \mathrm{C}$ & 0,00 & 0,58 & 0,42 & 0,00 & 0,14 & 0,10 & 0,24 \\
\hline & $250^{\circ} \mathrm{C}$ & 0,00 & 0,37 & 0,63 & 0,00 & 0,05 & 0,08 & 0,13 \\
\hline & $300^{\circ} \mathrm{C}$ & 0,00 & 0,13 & 0,87 & 0,00 & 0,01 & 0,05 & 0,06 \\
\hline & $320^{\circ} \mathrm{C}$ & 0,00 & 1,00 & 0,00 & 0,00 & 0,01 & 0,00 & 0,01 \\
\hline \multirow{4}{*}{ 空 } & $220^{\circ} \mathrm{C}$ & 1,00 & 0,00 & 0,00 & 7,99 & 0,00 & 0,00 & 7,99 \\
\hline & $250^{\circ} \mathrm{C}$ & 0,97 & 0,00 & 0,03 & 1,67 & 0,00 & 0,04 & 1,72 \\
\hline & $300^{\circ} \mathrm{C}$ & 1,00 & 0,00 & 0,00 & 0,93 & 0,00 & 0,00 & 0,93 \\
\hline & $320^{\circ} \mathrm{C}$ & 0,99 & 0,01 & 0,00 & 0,53 & 0,00 & 0,00 & 0,53 \\
\hline \multirow{4}{*}{$\overleftrightarrow{\Psi}$} & $220^{\circ} \mathrm{C}$ & 0,80 & 0,03 & 0,17 & 2,07 & 0,09 & 0,45 & 2,60 \\
\hline & $250^{\circ} \mathrm{C}$ & 0,59 & 0,22 & 0,19 & 1,18 & 0,44 & 0,37 & 1,98 \\
\hline & $300^{\circ} \mathrm{C}$ & 0,28 & 0,55 & 0,17 & 0,35 & 0,67 & 0,21 & 1,23 \\
\hline & $320^{\circ} \mathrm{C}$ & 0,29 & 0,58 & 0,13 & 0,24 & 0,48 & 0,11 & 0,84 \\
\hline \multirow{4}{*}{ 至 } & $220^{\circ} \mathrm{C}$ & 0,00 & 0,02 & 0,98 & 0,00 & 0,26 & 10,55 & 10,81 \\
\hline & $250^{\circ} \mathrm{C}$ & 0,00 & 0,37 & 0,63 & 0,00 & 0,16 & 0,26 & 0,42 \\
\hline & $300^{\circ} \mathrm{C}$ & 0,00 & 0,26 & 0,74 & 0,00 & 0,06 & 0,19 & 0,25 \\
\hline & $320^{\circ} \mathrm{C}$ & 0,00 & 0,25 & 0,75 & 0,00 & 0,04 & 0,13 & 0,18 \\
\hline \multirow{4}{*}{ 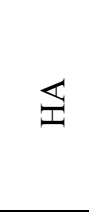 } & $220^{\circ} \mathrm{C}$ & 1,00 & 0,00 & 0,00 & 2,05 & 0,00 & 0,00 & 2,05 \\
\hline & $250^{\circ} \mathrm{C}$ & 0,73 & 0,15 & 0,11 & 0,70 & 0,15 & 0,10 & 0,95 \\
\hline & $300^{\circ} \mathrm{C}$ & 0,12 & 0,59 & 0,29 & 0,04 & 0,21 & 0,10 & 0,36 \\
\hline & $320^{\circ} \mathrm{C}$ & 0,15 & 0,50 & 0,35 & 0,04 & 0,12 & 0,09 & 0,25 \\
\hline \multirow{4}{*}{ 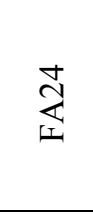 } & $220^{\circ} \mathrm{C}$ & 0,93 & 0,02 & 0,05 & 13,01 & 0,31 & 0,71 & 14,03 \\
\hline & $250^{\circ} \mathrm{C}$ & 0,70 & 0,21 & 0,10 & 2,19 & 0,65 & 0,31 & 3,14 \\
\hline & $300^{\circ} \mathrm{C}$ & 0,22 & 0,68 & 0,10 & 0,33 & 1,02 & 0,14 & 1,49 \\
\hline & $320^{\circ} \mathrm{C}$ & 0,29 & 0,58 & 0,13 & 0,24 & 0,48 & 0,11 & 0,84 \\
\hline
\end{tabular}

7. táblázat. Heteroaromás vegyületek arányai. $N, S, O$ : adott heteroatomot tartalmazó aromás vegyületek; NSO: összes mért heteroaromás; aro: összes aromás szénhidrogén.

Mivel a TIC kromatogramokból határoztam meg a mennyiségeket (3.1 fejezet), így csak relatív koncentrációkról beszélek. Mivel az alkilbenzolok és PAH-ok mennyisége ismert, nem félrevezető, ha a heteroaromás vegyületek eloszlásának értelmezésekor az aromás szénhidrogénekhez és egymáshoz viszonyított arányaikat használom fel. 


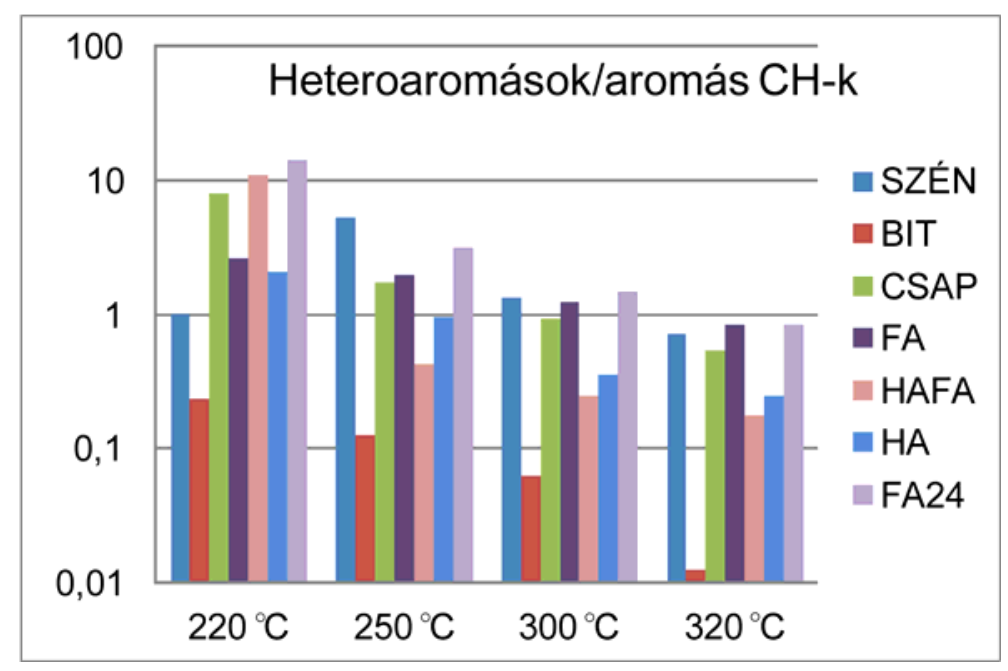

5. ábra. Heteroaromások/aromás CH-ek.

Az összes heteroaromás vegyület relatív mennyisége $\left(\sum \mathrm{ha} / \sum \mathrm{aCH}\right)$ csökken a hőmérséklet emelkedésével (5. ábra). Megfigyelhető, hogy $220^{\circ} \mathrm{C}$-on a heteroaromás vegyületek mennyisége jelentősen meghaladja az aromás szénhidrogénekét $\left(1<\sum \mathrm{ha} / \sum \mathrm{aCH}<10\right)$, majd $320^{\circ} \mathrm{C}$-ot elérve ez az arány 1 alá csökken. Kiugró értékekkel jellemezhető a BIT, ahol a kezdeti érték is rendkívül kicsi $(\sim 0,2)$, ami még tovább csökken, $320^{\circ} \mathrm{C}$-on megközelítve a 0,01-et. Egyedül a SZÉN esetében található maximum a $250^{\circ} \mathrm{C}$-os hőmérsékleten, ami egybeesik az alkilbenzolok és a PAH-ok minimumával.

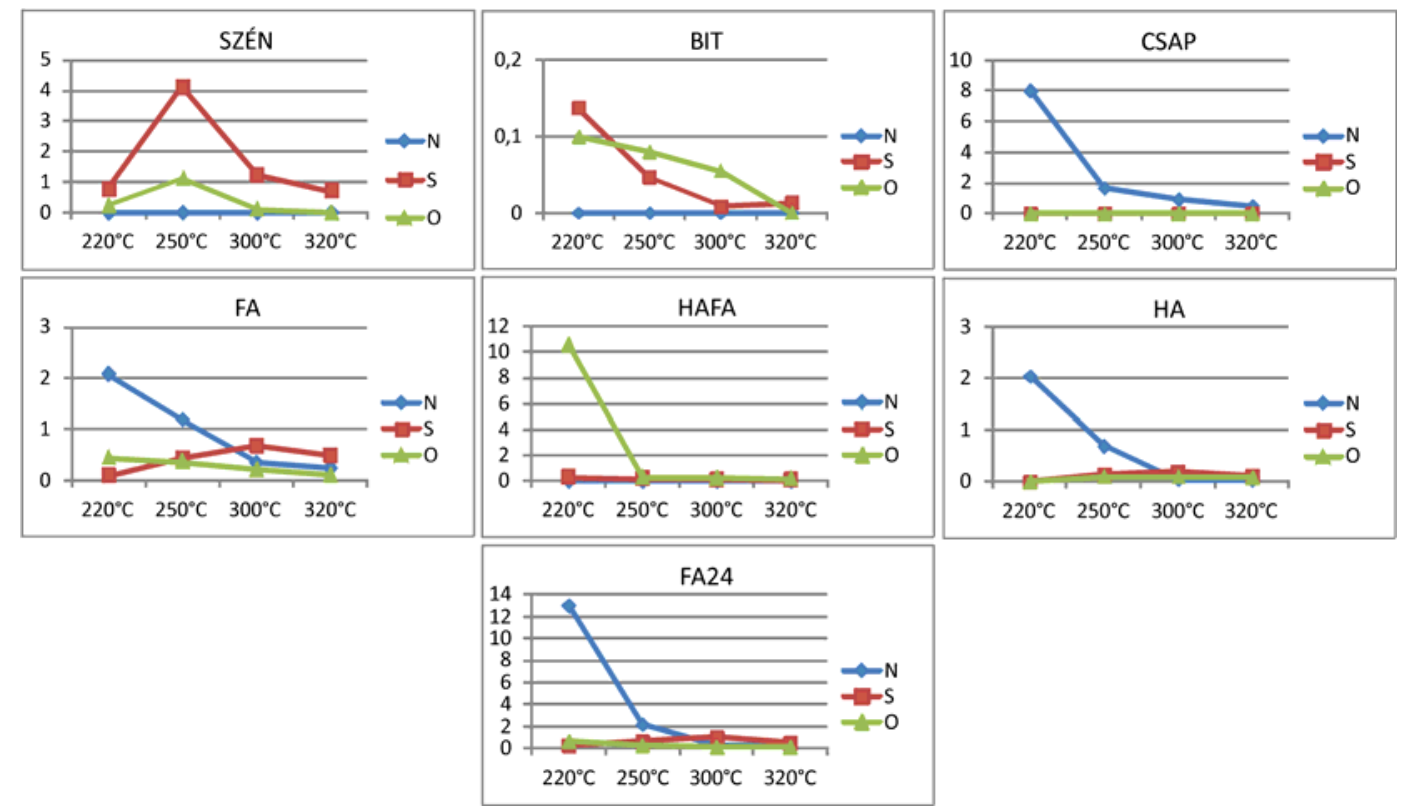

6. ábra. Heteroaromások aránya az egyes kísérletekben, heteroaromás/összes aromás CH.

Az N, S, O heteroaromásokat (heteroaromás/aromás szénhidrogének) külön tekintve (6. ábra) különbségeket figyelhetünk meg az adott elem és a különféle kísérleti anyagok tekintetében 
is. N vegyületek (elsősorban pirrolok) nem jelennek meg a SZÉN, BIT és HAFA mintákban, míg mennyiségük a többi mintában csökkenő tendenciát mutat. A CSAP és FA24 nagyon nagy értékekkel bír a FA és HA-hoz képest.

Aromás kénvegyületek, amik főleg tiofének és dibenzotiofének (S) legnagyobb mennyiségben a SZÉN-ben jelennek meg. A $250^{\circ} \mathrm{C}$-os kiugró érték után csökken az arányuk. A BIT és HAFA kísérletekben arányuk folyamatosan csökken a növekvő hőmérséklettel, míg a FA, HA és FA24-ben $300^{\circ} \mathrm{C}$-ig nő, $320^{\circ} \mathrm{C}$-ig csökken. Az arányok a rövidebb FA24 kísérletben nagyobbak.

O-tartalmú heteroaromások (furánok és benzofuránok) a SZÉN-ben szintén $250^{\circ} \mathrm{C}$-on mutatnak maximum értéket, ugyanígy a CSAP sorozatban is. A HAFA estében $220^{\circ} \mathrm{C}$-on kimagasló értéket láthatunk. A FA, FA24 és BIT sorozatban az arányok a hőmérséklet növekedésével csökkennek, míg a HA kísérletben 0-ról 0,1-re nőnek és nagyjából stagnálnak $250^{\circ} \mathrm{C}$-tól felfelé. A HA, CSAP és BIT esetében az értékek minden hőmérsékleten nagyon $\operatorname{kicsik}(\sim 0,1$ alatt $)$. 


\subsubsection{Fenolok a kísérleti anyagokban}

A fenol mérések eredményei a 8. táblázatban láthatók. A 24 órás FA kísérletek $320^{\circ} \mathrm{C}$-os lépése sajnos hiányzik, bár ez az értelmezést nem befolyásolja. Az összes fenoltartalmat (7E. ábra) tekintve a HA kiugróan nagy koncentrációkat mutat, határozott csúccsal $300^{\circ} \mathrm{C}$-on.

\begin{tabular}{|c|c|c|c|c|c|c|c|c|}
\hline Minta & Hőmérséklet & fenol & $\begin{array}{l}\text { metilfenolok } \\
\quad(\mathrm{F} 1)\end{array}$ & $\mathrm{F} 2$ & $\mathrm{~F} 3$ & $\begin{array}{c}\text { összes } \\
\text { fenol }\end{array}$ & $\begin{array}{c}\text { (fenol+metilfenolok)/ } \\
\text { összes fenol }\end{array}$ & $\begin{array}{l}\text { fenol/összes } \\
\text { fenol }\end{array}$ \\
\hline \multirow{4}{*}{$\begin{array}{l}Z \\
\text { I } \\
\text { N }\end{array}$} & $220^{\circ} \mathrm{C}$ & 0 & 0,0 & 0,0 & 0,0 & 0,0 & - & - \\
\hline & $250^{\circ} \mathrm{C}$ & 0,02 & 0,0 & 0,0 & 0,0 & 0,0 & 1,0 & 0,5 \\
\hline & $300^{\circ} \mathrm{C}$ & 0,03 & 0,1 & 0,1 & 0,0 & 0,2 & 0,6 & 0,2 \\
\hline & $320^{\circ} \mathrm{C}$ & 0,03 & 0,1 & 0,1 & 0,0 & 0,2 & 0,6 & 0,1 \\
\hline \multirow{4}{*}{ 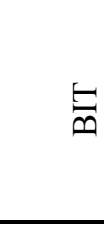 } & $220^{\circ} \mathrm{C}$ & 0,01 & 0,0 & 0,0 & 0,0 & 0,0 & 1,0 & 0,5 \\
\hline & $250^{\circ} \mathrm{C}$ & 0,01 & 0,1 & 0,0 & 0,0 & 0,1 & 0,5 & 0,1 \\
\hline & $300^{\circ} \mathrm{C}$ & 0,03 & 0,2 & 0,3 & 0,0 & 0,5 & 0,4 & 0,1 \\
\hline & $320^{\circ} \mathrm{C}$ & 0,08 & 0,3 & 0,2 & 0,1 & 0,7 & 0,6 & 0,1 \\
\hline \multirow{4}{*}{ 芯 } & $220^{\circ} \mathrm{C}$ & 0 & 0,0 & 0,0 & 0,0 & 0,0 & - & - \\
\hline & $250^{\circ} \mathrm{C}$ & 0 & 0,0 & 0,0 & 0,0 & 0,0 & - & - \\
\hline & $300^{\circ} \mathrm{C}$ & 0,02 & 0,0 & 0,0 & 0,0 & 0,1 & 0,7 & 0,3 \\
\hline & $320^{\circ} \mathrm{C}$ & 0,01 & 0,0 & 0,0 & 0,0 & 0,1 & 0,5 & 0,2 \\
\hline \multirow{4}{*}{ 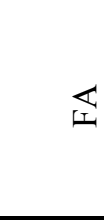 } & $220^{\circ} \mathrm{C}$ & 0,12 & 0,0 & 0,0 & 0,0 & 0,1 & 1,0 & 1,0 \\
\hline & $250^{\circ} \mathrm{C}$ & 0,03 & 0,0 & 0,0 & 0,0 & 0,1 & 1,0 & 0,6 \\
\hline & $300^{\circ} \mathrm{C}$ & 0,03 & 0,1 & 0,1 & 0,0 & 0,2 & 0,6 & 0,1 \\
\hline & $320^{\circ} \mathrm{C}$ & 0,04 & 0,2 & 0,2 & 0,0 & 0,4 & 0,5 & 0,1 \\
\hline \multirow{4}{*}{ 焉 } & $220^{\circ} \mathrm{C}$ & 0 & 0,0 & 0,0 & 0,0 & 0,0 & 1,0 & - \\
\hline & $250^{\circ} \mathrm{C}$ & 0,01 & 0,0 & 0,0 & 0,0 & 0,0 & 1,0 & 1,0 \\
\hline & $300^{\circ} \mathrm{C}$ & 0,05 & 0,1 & 0,0 & 0,0 & 0,1 & 0,9 & 0,4 \\
\hline & $320^{\circ} \mathrm{C}$ & 0,14 & 0,2 & 0,0 & 0,0 & 0,3 & 0,9 & 0,4 \\
\hline \multirow{4}{*}{$\overleftrightarrow{I}$} & $220^{\circ} \mathrm{C}$ & 0,41 & 0,0 & 0,0 & 0,0 & 0,5 & 1,0 & 0,9 \\
\hline & $250^{\circ} \mathrm{C}$ & 0,52 & 0,1 & 0,0 & 0,0 & 0,6 & 1,0 & 0,9 \\
\hline & $300^{\circ} \mathrm{C}$ & 0,91 & 0,4 & 0,0 & 0,0 & 1,3 & 1,0 & 0,7 \\
\hline & $320^{\circ} \mathrm{C}$ & 0,3 & 0,3 & 0,1 & 0,0 & 0,8 & 0,8 & 0,4 \\
\hline \multirow{3}{*}{ 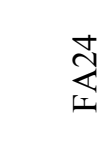 } & $220^{\circ} \mathrm{C}$ & 0,04 & 0,0 & 0,0 & 0,0 & 0,0 & 1,0 & 1,0 \\
\hline & $250^{\circ} \mathrm{C}$ & 0,06 & 0,0 & 0,0 & 0,0 & 0,1 & 1,0 & 0,8 \\
\hline & $300^{\circ} \mathrm{C}$ & 0,12 & 0,1 & 0,0 & 0,0 & 0,3 & 0,8 & 0,4 \\
\hline
\end{tabular}

8. táblázat. Fenol vegyületcsoportok koncentrációi ( $\mathrm{mg} / \mathrm{l})$ és mutatók a kísérletekben.

Sok fenol keletkezik a BIT mintából is. Ebben és a többi mintában is, a fenolok mennyisége nő az emelkedő hőmérséklettel, bár a FA esetében a minimum $250^{\circ} \mathrm{C}$-nál van. A legkevesebb 
fenol a CSAP mintából keletkezik. A FA24 kísérletekben mért összes fenol koncentrációk kicsivel meghaladják a FA mintákban mérteket.

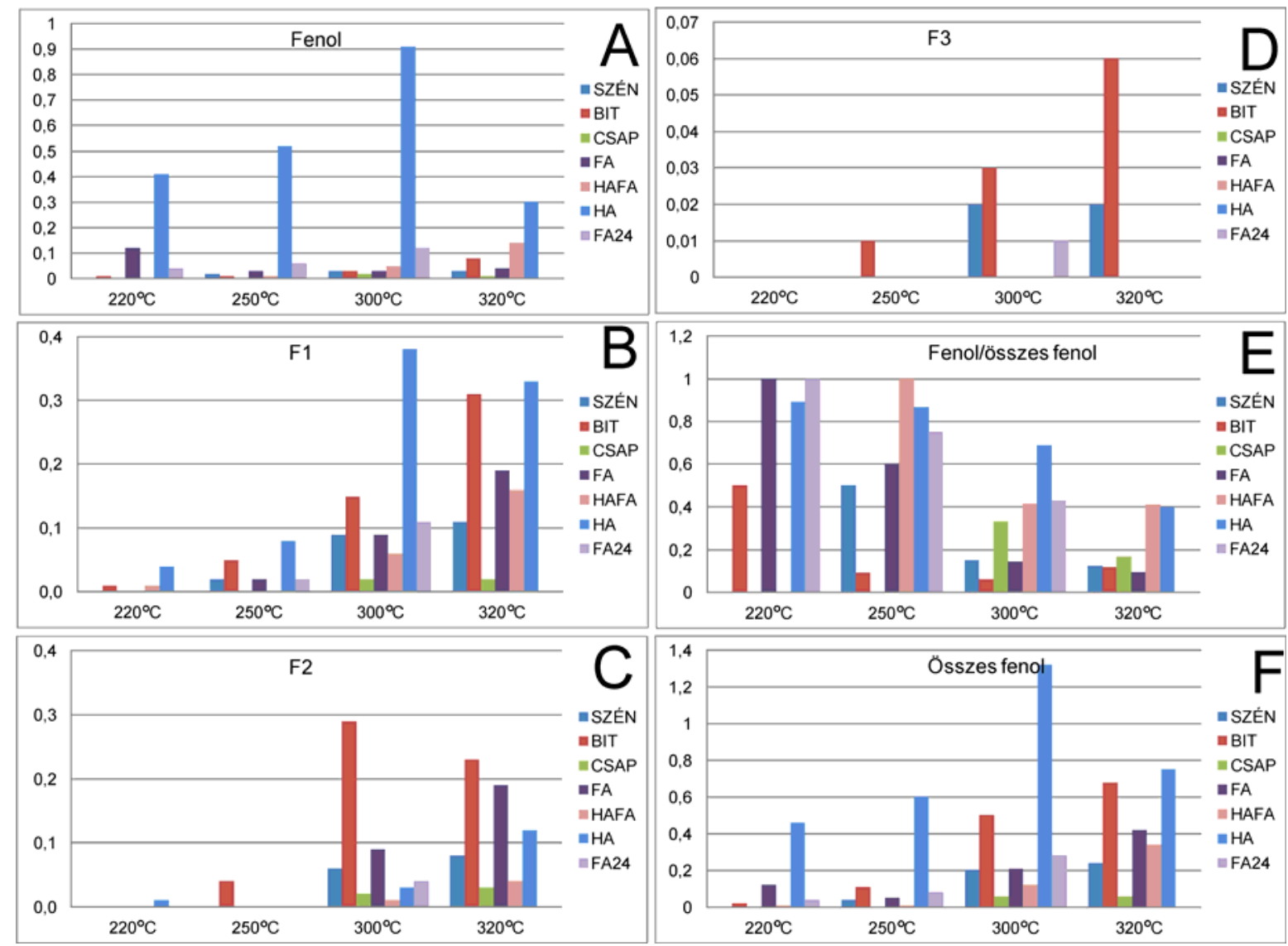

\section{7. ábra. Fenolok koncentrációi (mg/l) és mutatók a kísérletekben.}

A fenolt önmagában és az alkilfenolokat tekintve a HA kiugróan sok fenolt (7A.ábra) és metilfenolt (7B. ábra) termel, F2 vegyületekből (7C. ábra) közepes mennyiséget, míg F3 vegyületeket (7D. ábra) egyáltalán nem. A fenol keletkezése a FA-ban $220^{\circ} \mathrm{C}$ felett visszaesik, majd alig emelkedik, míg a többi minta esetében folyamatosan nő az emelkedő hőmérséklettel. A CSAP értékek $300^{\circ} \mathrm{C}$ és $320^{\circ} \mathrm{C}$ között csökkenek, de meg kell jegyezni, hogy a CSAP mintákban mért koncentrációk a mérési határ közelében ingadoznak.

A metilfenol koncentrációk (F1) esetében is látszik a HA $300^{\circ} \mathrm{C}$-os csúcsa, illetve itt is második a BIT. A hőmérséklettel való koncentrációnövekedés minden mintában megfigyelhető, ez hasonló az F2 fenolokat tekintve is. F2 vegyületeket legnagyobb mennyiségben a BIT szolgáltat, aminek $300^{\circ} \mathrm{C}$-nál a HA F1 fenoljaihoz hasonló csúcsa van. F3 fenolok csak a SZÉN, BIT és FA24 mintákban jelennek meg.

A relatív demetileződést mutató arányok (fenol/összes fenolok, $\mathrm{f} / \Sigma \mathrm{f}$, illetve (fenol+metilfenolok)/összes fenol, fmf $/ \Sigma \mathrm{f}$ ) a BIT kivételével csökkennek a növekvő 
hőmérséklettel. A BIT kísérletekben a minimum $300^{\circ} \mathrm{C}$-on látható, majd a mutató értéke kissé megnő. A $220^{\circ} \mathrm{C}$ és $250^{\circ} \mathrm{C}$ közötti esés azonban jelentős. Ennek megfelelöen a fenolok esetében relatív metileződést figyelhetünk meg.

\subsection{Következtetések}

Az eredmények alapján a reakciók, azaz a termékek keletkezése és átalakulása (lebomlás vagy nagyobb molekulasúlyú vegyületek kialakulása, kondenzáció) párhuzamosan folynak. A kezelési idő és a hőmérséklet befolyásolja a különféle reakciók intenzitását, tehát időben elörehaladva vagy nagyobb hőmérsékleten egyes folyamatok egyre hangsúlyosabbá válnak. Például a rövidebb kezelés alatt nagyobb koncentrációban jelen levő komponensek (pl. C2, C3) hosszabb idő alatt eltünnek (demetileződésen vagy polikondenzáción mennek át), de ennek ellenére a termékek összes mennyisége a hőmérséklettel párhuzamosan nő, mivel a kisebb és nagyobb hőstabilitású vegyületek képződése a prekurzor anyagból és az ellenállóbbaké az átalakuló molekulákból egyaránt tovább folytatódik.

A termékek minősége és mennyisége a prekurzor anyagi minőségét és a relatív érettségének (aromatizáció előrehaladása, heteroatomvesztés) hatását egyaránt jól mutatja. A HA-ból nagyobb arányban képződnek hosszabb szénláncú alkilbenzolok, mint a FA-ból, ahol a fő termék a benzol. Ha elfogadjuk az általános modellt, amely szerint a huminsavak aromásabbak, és hosszabb szénláncokat tartalmaznak, mint a fulvosavak (amikben a reaktív funkciós csoportok aránya nagyobb), akkor ennek magyarázata az, hogy a fulvosavakban gyakoribbak a különálló gyürük, míg a huminsavakban a poliaromás/gyürüs szerkezetek dominálnak. Mivel a benzolgyürü meglehetősen ellenálló a hőkezeléssel szemben, és a polikondenzációs reakciók erőteljesek, nem meglepő, hogy a HA-ból jóval kevesebb alkilbenzolt kapunk, mint a FA-ból, viszont a képződő alkilbenzolokhoz hosszabb szénláncok kapcsolódnak. Erről bővebben írok a PAH-okról szóló részben. Valamennyire hasonló a helyzet a BIT esetében is, ahol a hosszú szénláncúak erőteljes megjelenése nem meglepő, mivel jelen vannak a bitumenben (Tissot és Welte, 1984).

A SZÉN a kísérleti anyagok közül a leginkább érett (Tissot és Welte, 1984) nagy arányban polikondenzált, aromás szerkezeteket tartalmaz, ezért általában a legkisebb benzol és alkilbenzol hozamokat produkálja. A benzol minimum a $250^{\circ} \mathrm{C}$-os kísérletben azt mutatja, hogy elöször a könnyen leszakadó benzol jelenik meg a vízben, majd a hőmérsékletnek el kell 
érnie egy bizonyos szintet, hogy a nehezen hozzáférhető részekről is magányos gyürük szakadjanak le, vagy a demetileződés eléggé előrehaladjon. A b/t és bt/a mutató csökkenésére az egyetlen magyarázat az lehet, hogy vannak olyan kondenzált, például heteroaromás részek, amelyek alkilbenzolokká bomlanak a hőkezelés hatására. Ebből az a következtetés adódik, hogy a szenekben megtalálható heteroatomok inkább aromás szerkezetekben vannak jelen, míg például a humin anyagokban sok heteroatomos funkciós csoport található. Ugyanezt lehet elmondani a BIT-ről is azzal a különbéggel, hogy az éretlen bitumen nem annyira polikondenzált, mint a szén, és a C3, C4+ nagy mennyisége a hosszabb alifás láncok jelenlétét is jól mutatja.

Ha ezek alapján elfogadjuk, hogy a keletkező vegyületek jól tükrözik a kísérleti anyag kémiai szerkezetét, az ismeretlen szerkezetü CSAP mintáról azt a következtetést vonhatnánk le, hogy alig tartalmaz hosszabb szénláncokat, rövidebbekben azonban bővelkedik (nagyon nagy toluol és C2 termelés, minimális C3 és C4+). Meg kell jegyeznem, hogy a legnagyobb koncentrációban előforduló C2 alkilbenzol a sztirol, ami mesterséges eredetre utal. Ha figyelembe vesszük, hogy a geotermikus kutakban használt szürök müanyagokból készülnek, ez könnyen elöfordulhat.

A policiklikus aromás vegyületek megfigyelt eloszlásának értelmezése nem egyszerü. Ennek fö oka, hogy a PAH-ok hideg vizekben is megjelennek (lásd pl. következő fejezet), tehát oldódás termékei is lehetnek, valamint aszkorbinsavból is keletkeznek a hőkezelés hatására.

Az, hogy a vizsgált minták közül a legnagyobb PAH termelök a kevésbé (FA, HAFA) és a nagymértékben aromatizált (SZÉN) szerkezetek (Tissot és Welte, 1984), arra utal, hogy a PAH-ok keletkezésért a makromolekulákról való leszakadás mellett nagymértékben felelős az egy gyürüs aromás vegyületek hőmérséklet hatására növekvő kondenzációja. A kondenzáció hatását mutatja az, hogy az aszkorbinsavból is képződnek PAH vegyületek. Az eleve poliaromás részleteket tartalmazó HA PAH vegyületei tovább kondenzálódnak és részben kicsapódnak, így eltünnek a mérhető tartományból, viszont a makromolekuláról kevesebb PAH képes leszakadni, mint a SZÉN esetében. Emellett a huminsavak tartalmazhatnak heteroaromás részeket, amik a hőkezelés hatására lebomlanak, így alkilbenzolok és PAH-ok ezúton is keletkezhetnek. A SZÉN-böl is sok PAH (viszont kevés alkilbenzol) keletkezik, tehát kell, hogy legyen olyan folyamat, amivel a nagyméretü molekulákból 2-6 gyürüs szerkezetek szabadulnak fel. Mivel az aromás gyürük felszakadása nem valószínü, a heteroatomot tartalmazó aromás szerkezetek felszakadása egy lehetséges út ehhez. Az, hogy a SZÉN mintában - az alkilbenzolokhoz hasonlóan - $250^{\circ} \mathrm{C}$-nál minimum jelentkezik az összes 
PAH koncentrációban, szintén azt mutatja, hogy a könnyen leszakadó molekularészek $220^{\circ} \mathrm{C}$ on az oldatba kerültek, míg az újabb keletkezéshez nagyobb hőmérsékletre van szükség.

A FA és FA24 eredményeket tekintve elmondható, hogy a vegyületek bomlással történő keletkezése gyorsabb folyamat, mint a polikondenzáció.

A mnaf/naf arány a b/t-hez hasonlít. Mivel az alkilbenzolok esetében sem a b/t, sokkal inkább a bt/a mutatja a relatív demetileződést, és PAH-ok esetében nem volt mód hosszabb (vagy több) alkilláncot tartalmazó vegyületeket vizsgálni, a mutató csak megerősíti, nem bizonyítja a hőmérséklet növekedésével előrehaladó demetileződést.

A f/a csökken a hömérséklet emelkedésével. A fenantrén meglehetősen stabil vegyület, míg az antracén föleg a hőkezelés hatására keletkezik. Ha az antracén idővel nem bomlik le vagy alakul át, ez a mutató a felszín alatti vizek maximális hőmérsékletét mutathatja. Ugyanezt az emelkedő hőmérséklettel történő fenantrén/antracén arány csökkenést írta le Sajgó et al. (2005) néhány, a Pannon-medencéből származó hévízben.

A heteroaromás vegyületek eloszlása a kísérleti anyag érettségét és a vegyületek hőstabilitását is jól tükrözi. Ha az aromás szénhidrogének mennyiségét is figyelembe vesszük, a CSAP, FA és $250^{\circ} \mathrm{C}$ felett a SZÉN termel a hökezelések során sok heteroaromás vegyületet. A heteroaromás szerkezetek hőstabilitása kisebbnek mutatkozik, mint az aromásoké, ami az irodalmi adatokkal egybevág (pl. Katritzky et al., 2001., illetve 1. fejezet).

Az érettebbnek tekinthető anyagokból (szén, bitumen és a mély, forró hévízből származó humin anyag) a nitrogéntartalmú aromások hiányoznak. Ehhez hozzávéve, hogy a hőmérsékletemelkedés hatására a többi mintában milyen intenzíven csökken az arányuk, feltehető, hogy az érés során ezek a vegyületek elvesznek. A kéntartalmú aromások viselkedése az azonos környezetből származó FA-ban és HA-ban (és a FA24-ben) megegyezik, míg az oxigéntartalmúak csak a két FA kísérletben változnak egyformán.

Megfigyelhető, hogy a FA értékei mindig meghaladják a HA-ét, ez egybevág az azonos helyről származó huminsavak fulvosavakhoz viszonyított kisebb heteroatom tartalmával (pl. Kovács, 2010). A HAFA $220^{\circ} \mathrm{C}$ felett mindig kisebb $\sum$ ha $/ \sum \mathrm{aCH}$ értékeket mutat, mint a HA vagy FA, ami szintén megfelel a Kovács (2010) és Kovács et al. (2012) által a természetben megfigyelt folyamatnak: a mélység (és a hömérséklet) növekedésével a humin anyagok heteroatom tartalma csökken.

Fontos megfigyelés, hogy a heteroaromás vegyületek kis kezelési hőmérsékleten uralkodó vegyületek, míg a mesterséges érés hatására nagyon hamar lecsökken arányuk az aromás szénhidrogénekhez képest. 
A fenolok eloszlása nehezen értelmezhető annak ellenére, hogy követik az egyéb aromás vegyületeknél megfigyelt viselkedést, azaz koncentrációjuk nő a hőmérséklettel. A HA kiugróan nagy értékeiböl arra kell következtetni, hogy a fenolos csoportok különösen elterjedtek a huminsavakban. Fenol dihidrobenzofuránból is keletkezhet vizes pirolízis kísérletekben (Katritzky et al., 1990), de a HA minták nem mutattak nagy gazdagságot ezekben a vegyületekben.

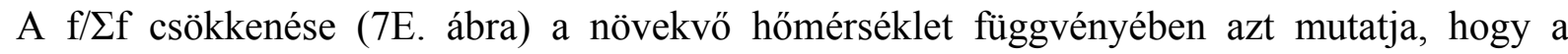
képződő alkilfenolok utánpótlása böséges. Az a tény, hogy az F3 fenolok a rövid FA24 kísérletben megjelennek, a FA-ban azonban nem, azt mutatja, hogy az idő előrehaladtával a relatív demetileződés lejátszódott. Ugyanezt mutathatja a BIT esetében a mutató növekedése, illetve kismértékü csökkenése vagy stagnálása (FA, HAFA, SZÉN) $300^{\circ} \mathrm{C}$ és $320^{\circ} \mathrm{C}$ között. Mindenképp meg kell jegyezni, hogy a legtöbb fenol homológ koncentrációja 0-ról indul $\left(220^{\circ} \mathrm{C}\right.$-on). Ez azt jelenti, hogy - a természetben megfigyelt jelenséghez hasonlóan - a fenolok a nagyobb hőmérsékleteken válnak uralkodó vegyületekké a vizekben. 


\section{5 Összefoglalás}

Összefoglalásként elmondható, hogy a vizsgált intervallumban a hőmérséklet emelkedésével az alábbi reakciók játszódnak le:

- C-C vagy C-heteroatom kötések bomlásával és heteroatomos gyürük felbomlásával a prekurzor anyagból változatos méretü molekularészek szakadnak le és bomlanak tovább hasonló reakciók során aromás szénhidrogénekké;

- általában relatív demetileződés játszódik le, a növekvő hőmérséklettel és idővel a rövidebb alkilláncú vegyületek aránya megnő;

- polikondenzáció és aromatizáció játszódik le;

A keletkezett vegyületek közel azonosak, de ezek mennyisége és főleg arányuk eltérő a különféle kiindulási (prekurzor) anyagokban, aminek oka az eltérő kémiai szerkezet és összetétel.

A vizes pirolízis (pontosabban aqatermolízis) kísérletek - amennyiben reduktív környezetet alkalmazunk - alkalmasak a szerves anyag vizekben lejátszódó termikus változásainak, illetve érésének szimulációs vizsgálatára. A természetben (a Pannon-medence hévizei esetében) megfigyelt $\sim 80^{\circ} \mathrm{C}$-os küszöbhömérséklet a vizsgált vegyületek koncentrációi alapján nagyjából megfelel a $220^{\circ} \mathrm{C}$ kísérleti hőmérsékletnek, 72 órás hőkezelés esetében. Ennek egyik bizonyítéka, hogy a vizsgált vegyületek hévizekben megfigyelt sorozatos megjelenése (növekvő hőmérséklettel: heteroaromások, alkilbenzolok majd fenolok) a kísérletekben is hasonlóan alakult.

Mivel a megjelenő vegyületek között nem találhatóak bármely kiindulási anyagra kizárólagosan jellemző vegyületek, a természetes hévizekben megtalálható oldott szerves anyagok eredetére csak közvetetten (például a különféle vegyületek arányaiból) következtethetünk. 


\section{4. Összefüggés a hévizek hőmérséklete, szerves anyagának bomlása és szervetlen összetevői között}

A Pannon-medence hévizeiben oldott aromás szerves anyagok eredetéről csak feltevések vannak. Származhatnak a beszivárgás idején a felszín alatti vízbe kerülő talajeredetű szerves anyagból, illetve egyéb, az üledékben diszperz módon (bitumen) vagy koncentráltan (pl. lignit vagy szén telepek) jelen levő szerves anyag felhalmozódásokból is, amikkel a víz útja során kölcsönhatásba kerül. Emellett kőolajtelepekkel kapcsolatban levő vizek is tartalmazhatnak illó aromás vegyületeket. Ahhoz, hogy a nagy molekulasúlyú anyagok illó (jelen esetben: kromatografálható) szerves vegyületekre való bomlásáról információt szerezzünk, az oldott aromás vegyületek kvantitatív meghatározása mellett megfelelő közvetett módszer a vizek egyéb kémiai paramétereinek vizsgálata is.

Ebben a fejezetben bemutatom, hogy a különféle eredetủ szerves anyagok bomlása - amellett, hogy a széndioxid képződése miatt hatással van a vizek szervetlen kémiai összetételére egyben forrása a hévizekben kimutatható aromás szerves vegyületeknek is, elsősorban az alkilbenzoloknak és a fenoloknak. Az eredmények bemutatása nagyban támaszkodik már megjelent publikációkra (Fekete et al., 2009; 2010b), de értekezésemben eltérő szemszögből vizsgálom a hévizek tulajdonságait.

\subsection{A hévizek csoportosítása}

A hévíz mintákon korábban vizsgáltam a szervesanyag-bomlás elörehaladásának és a szervetlen komponensek átlagos koncentrációjának kölcsönhatását (Fekete et al., 2009; 2010b). Ebben a fejezetben a hangsúlyt arra fektetem, hogy bemutassam azt, hogy a szerves anyagok bomlása 1) bizonyos hőmérsékleti küszöbértékhez kötött ( $\sim 0^{\circ} \mathrm{C}$ kifolyó); 2) a szervetlen összetételt $\left(\mathrm{Na}^{+}-, \mathrm{HCO}_{3}{ }^{-}\right.$-tartalom) nagyban befolyásoló széndioxid mellett milyen aromás vegyületeket termel; 3) ezek koncentrációja mennyiben függ a TOC-tartalomtól; és 4) mennyiben függ a kiindulási szerves anyag tengeri vagy szárazföldi eredetétől.

A hévizeket a továbbiakban két csoportra bontva vizsgálom 1) fenolokat nem tartalmazó hévizek (fenolmentes), 2) fenolokat tartalmazó hévizek (fenolos A és B). Ennek az az oka, hogy a korábbi vizsgálatok (pl. Kárpáti, 1999) alapján elsősorban a fenolok a melegebb vizek 
jellemző aromás szerves anyagai, míg a benzol és az alkilbenzolok kis koncentrációban már kevésbé meleg, a PAH-ok pedig hideg vizekben is nagy koncentrációban lehetnek jelen. A fenoltartalmú csoportban három mintát a többitől eltérően jelöltem (fenolos B), mert amellett, hogy 0-hoz közeli $\delta^{18} \mathrm{O}$ értékekkel bírnak - egyéb tulajdonságaikban is eltérnek.

Ebben a fejezetben bemutatom, hogy a két csoport között több egyértelmü különbség is van. Mivel a korábbi megfigyelések alapján a hévíz hőmérsékletének emelkedésével a domináns aromás vegyületek sorrendje a következö: heteroaromások, alkilbenzolok, fenolok (Kárpáti, 1999), a fenolokat tartalmazó hévizek szerves anyagát érettebbnek tekintem. A továbbiakban tehát a víz szerves anyagának érettségén a bármilyen kiindulási szerves anyag aromás vegyületekké való bomlásának előrehaladását értem.

\subsection{A hévizek szerves és szervetlen összetétele}

Az alkilbenzol, PAH és fenol csoportok koncentrációi és különféle koncentrációkból számolt arányok láthatók a 9., 10. és 11. táblázatban. A szerves elemzések részletesen a Függelékben találhatók. A 12. és 13. táblázat a hévizek fontosabb szervetlen kémiai paramétereit mutatja be.

A heteroaromás vegyületek általában a kis hőmérsékletű hévizekben jellemzőek (pl. Kárpáti, 1999). Az értekezésben vizsgált hévizekből általában hiányoznak, ahol megjelennek, ott a csúcsok területe $<1 \%$ a totálion kromatogramokban. Emiatt ebben a fejezetben bővebben nem tárgyalom ezeket. Mivel a 24 órás kísérletben arányuk nagyobb, mit a 72 órásban (3.3.5. fejezet), az mindenesetre feltételezhető, hogy a heteroaromás vegyületek a hőhatás időtartamára is rendkívül érzékenyek. Ezért hiányozhatnak a hévizekből (relatíve kis hőmérséklet, hosszú idő). 


\begin{tabular}{|c|c|c|c|c|c|c|c|c|c|c|}
\hline $\begin{array}{l}\text { Eredeti } \\
\text { jelölés }\end{array}$ & Vízhőm. & mintavétel helye & Benzol & Toluol & $\mathrm{C} 2$ & $\mathrm{C} 3$ & $\mathrm{C} 4$ & $\begin{array}{c}\text { összes } \\
\text { alkilbenzol }\end{array}$ & $\mathrm{bt} / \mathrm{a}$ & $\mathrm{b} / \mathrm{a}$ \\
\hline TMV027 & 38,0 & Szeged & 0,0 & 0,3 & 1,7 & 0,9 & 0,0 & 2,9 & 0,69 & 0,00 \\
\hline TMV020 & 44,0 & Sarkad & 0,0 & 0,0 & 1,3 & 0,5 & 0,4 & 2,2 & 0,59 & 0,00 \\
\hline TMV015 & 46,2 & Kiskunhalas & 0,0 & 0,6 & 0,0 & 0,0 & 0,2 & 0,8 & 0,75 & 0,00 \\
\hline TMV007 & 48,0 & Hajdúszoboszló & 0,0 & 0,1 & 0,0 & 0,0 & 0,0 & 0,1 & 1,00 & 0,00 \\
\hline TMV012 & 50,0 & Eger & 3,9 & 0,5 & 0,0 & 0,0 & 0,1 & 4,5 & 0,98 & 0,87 \\
\hline TMV009 & 56,0 & Berekfürdő & 2,1 & 1,2 & 0,4 & 0,1 & 0,0 & 3,8 & 0,97 & 0,55 \\
\hline TMV034 & 56,0 & Algyő 5-261 & 6,8 & 0,0 & 1,0 & 1,4 & 0,0 & 9,2 & 0,85 & 0,74 \\
\hline TMV022 & 58,0 & Zalaegerszeg & 5,8 & 2,5 & 2,3 & 0,9 & 0,1 & 11,6 & 0,91 & 0,50 \\
\hline TMV038 & 59,0 & Gyula & 4,5 & 1,6 & 4,0 & 1,0 & 0,0 & 11,1 & 0,91 & 0,41 \\
\hline TMV011 & 61,5 & Füzesgyarmat & 0,9 & 2,8 & 2,1 & 0,2 & 0,3 & 6,3 & 0,92 & 0,14 \\
\hline TMV017 & 62,0 & Szolnok & 4,9 & 1,8 & 0,8 & 0,2 & 0,3 & 8,0 & 0,94 & 0,61 \\
\hline TMV031 & 63,0 & Szolnok, 15-93 & 1300,0 & 124,7 & 377,0 & 94,0 & 4,2 & 1899,9 & 0,95 & 0,68 \\
\hline TMV005 & 65,0 & Babócsa & 78,2 & 0,0 & 7,6 & 4,4 & 1,1 & 91,3 & 0,94 & 0,86 \\
\hline TMV035 & 66,0 & Algyő 5-262 & 12,3 & 0,0 & 1,6 & 0,5 & 0,0 & 14,4 & 0,97 & 0,85 \\
\hline TMV010 & 66,0 & Földes K-29 & 200,0 & 12,1 & 1,2 & 0,0 & 0,0 & 213,3 & 1,00 & 0,94 \\
\hline TMV013 & 68,0 & Egerszalók & 1,8 & 0,9 & 0,0 & 0,0 & 0,1 & 2,8 & 0,96 & 0,64 \\
\hline TMV004 & 69,5 & Lenti & 75,4 & 10,3 & 20,7 & 9,2 & 2,2 & 117,8 & 0,90 & 0,64 \\
\hline TMV026 & 70,0 & Szeged & 65,9 & 13,3 & 65,7 & 37,9 & 0,0 & 182,8 & 0,79 & 0,36 \\
\hline TMV030 & 70,0 & Ásotthalom & 1150,0 & 122,7 & 307,3 & 107,9 & 23,1 & 1711,0 & 0,92 & 0,67 \\
\hline TMV032 & 70,0 & Végegyháza & 48,0 & 48,7 & 172,0 & 41,7 & 1,1 & 311,5 & 0,86 & 0,15 \\
\hline TMV008 & 70,0 & Hajdúszoboszló & 250,0 & 27,2 & 7,3 & 0,2 & 0,9 & 285,6 & 1,00 & 0,88 \\
\hline TMV019 & 72,0 & Nagybánhegyes & 181,7 & 158,4 & 648,7 & 84,8 & 2,8 & 1076,4 & 0,92 & 0,17 \\
\hline TMV042 & 73,5 & Hódmezőv. & 21,9 & 14,0 & 30,9 & 14,3 & 0,0 & 81,1 & 0,82 & 0,27 \\
\hline TMV021 & 76,0 & Deszk & 70,7 & 75,7 & 83,9 & 114,6 & 2,8 & 347,7 & 0,66 & 0,20 \\
\hline TMV041 & 76,0 & Makó & 5,3 & 5,3 & 10,9 & 5,2 & 0,7 & 27,4 & 0,78 & 0,19 \\
\hline TMV014 & 77,0 & Csengele & 3,1 & 1,1 & 0,4 & 0,2 & 0,0 & 4,8 & 0,96 & 0,65 \\
\hline TMV016 & 79,0 & Öcsöd & 29,6 & 33,6 & 28,4 & 5,2 & 1,1 & 97,9 & 0,94 & 0,30 \\
\hline TMV033 & 80,0 & Tótkomlós 3-105 & 27,2 & 14,9 & 28,6 & 4,1 & 0,0 & 74,8 & 0,95 & 0,36 \\
\hline TMV037 & 82,0 & Szarvas & 23,3 & 31,7 & 43,5 & 3,2 & 0,0 & 101,7 & 0,97 & 0,23 \\
\hline TMV024 & 82,0 & Domaszék 5-159 & 650,0 & 49,8 & 81,1 & 22,2 & 2,8 & 805,9 & 0,97 & 0,81 \\
\hline TMV025 & 82,0 & Domaszék 5-43 & 250,0 & 58,9 & 191,0 & 31,7 & 11,5 & 543,1 & 0,92 & 0,46 \\
\hline TMV029 & 84,0 & Szeged, 5-209 & 550,0 & 70,0 & 118,6 & 24,5 & 1,6 & 764,7 & 0,97 & 0,72 \\
\hline TMV028 & 84,5 & Szeged 5-94 & 138,7 & 55,8 & 87,8 & 31,6 & 1,2 & 315,1 & 0,90 & 0,44 \\
\hline TMV039 & 91,0 & Gyula & 15,8 & 19,8 & 29,1 & 3,0 & 0,0 & 67,7 & 0,96 & 0,23 \\
\hline TMV040 & 95,0 & Orosháza & 46,7 & 40,5 & 58,2 & 9,0 & 0,5 & 154,9 & 0,94 & 0,30 \\
\hline TMV036 & 96,5 & Szarvas 3-263 & 48,0 & 68,7 & 122,8 & 26,9 & 0,6 & 267,0 & 0,90 & 0,18 \\
\hline TMV023 & 99,0 & Zalakaros & 174,8 & 51,3 & 12,3 & 1,3 & 0,0 & 239,7 & 0,99 & 0,73 \\
\hline
\end{tabular}

9. táblázat. Alkilbenzol vegyületcsoportok mennyisége ( $\mu \mathrm{g} / \mathrm{l})$, és arányok a hévizekben. Bt/a: (benzol+toluol)/(benzol+alkilbenzolok); b/a: benzol/(benzol+alkilbenzolok). 


\begin{tabular}{|c|c|c|c|c|c|c|c|}
\hline $\begin{array}{l}\text { Eredeti } \\
\text { jelölés }\end{array}$ & Vízhőm. & $\begin{array}{l}\text { mintavétel } \\
\text { helye }\end{array}$ & Naftalin & $\mathrm{O} 3$ & O4+ & $\mathrm{f} / \mathrm{a}$ & összes PAH \\
\hline TMV027 & 38,0 & Szeged & 3600,0 & 2570,6 & 284,5 & 37,80 & 6455,1 \\
\hline TMV020 & 44,0 & Sarkad & 706,0 & 689,7 & 99,1 & 8,91 & 1494,8 \\
\hline TMV015 & 46,2 & Kiskunhalas & 886,0 & 5850,6 & 1146,6 & 50,53 & 7883,2 \\
\hline TMV007 & 48,0 & Hajdúszoboszló & 77,8 & 487,1 & 55,2 & 27,44 & 620,1 \\
\hline TMV012 & 50,0 & Eger & 33,6 & 143,0 & 20,8 & - & 197,4 \\
\hline TMV009 & 56,0 & Berekfürdő & 242,0 & 802,8 & 397,0 & 10,35 & 1441,8 \\
\hline TMV034 & 56,0 & Algyő 5-261 & 410,0 & 201,2 & 10,2 & - & 621,4 \\
\hline TMV022 & 58,0 & Zalaegerszeg & 39,3 & 6,6 & 42,4 & - & 88,4 \\
\hline TMV038 & 59,0 & Gyula & 432,0 & 362,6 & 158,5 & 12,76 & 953,1 \\
\hline TMV011 & 61,5 & Füzesgyarmat & 2060,0 & 15729,4 & 1285,9 & 28,34 & 19075,3 \\
\hline TMV017 & 62,0 & Szolnok & 1960,0 & 2662,4 & 421,0 & 11,80 & 5043,4 \\
\hline TMV031 & 63,0 & Szolnok, 15-93 & 7336,0 & 1855,6 & 113,2 & 21,38 & 9304,8 \\
\hline TMV005 & 65,0 & Babócsa & 149,6 & 1166,6 & 229,5 & - & 1545,7 \\
\hline TMV035 & 66,0 & Algyő 5-262 & 988,0 & 1701,0 & 244,5 & 51,79 & 2933,5 \\
\hline TMV010 & 66,0 & Földes K-29 & 1048,0 & 4912,0 & 329,6 & 28,60 & 6289,6 \\
\hline TMV013 & 68,0 & Egerszalók & 109,4 & 475,9 & 90,6 & 14,64 & 675,9 \\
\hline TMV004 & 69,5 & Lenti & 392,0 & 1777,2 & 51,7 & 183,62 & 2220,9 \\
\hline TMV026 & 70,0 & Szeged & 283,3 & 87,4 & 0,0 & - & 370,7 \\
\hline TMV030 & 70,0 & Ásotthalom & 0,0 & 1768,0 & 363,6 & 1,31 & 2131,6 \\
\hline TMV032 & 70,0 & Végegyháza & 4604,0 & 663,5 & 0,0 & - & 5267,5 \\
\hline TMV008 & 70,0 & Hajdúszoboszló & 17500,0 & 12152,6 & 489,6 & 77,95 & 30142,2 \\
\hline TMV019 & 72,0 & Nagybánhegyes & 23500,0 & 15579,5 & 516,8 & 75,56 & 39596,3 \\
\hline TMV042 & 73,5 & Hódmezőv. & 2630,0 & 2079,0 & 18,6 & 30,02 & 4727,6 \\
\hline TMV021 & 76,0 & Deszk & 8340,0 & 7784,2 & 307,6 & 27,09 & 16431,8 \\
\hline TMV041 & 76,0 & Makó & 4996,0 & 3388,8 & 525,6 & 3,00 & 8910,4 \\
\hline TMV014 & 77,0 & Csengele & 68,4 & 363,0 & 80,7 & 5,95 & 512,1 \\
\hline TMV016 & 79,0 & Öcsöd & 7300,0 & 4773,2 & 393,6 & 16,17 & 12466,8 \\
\hline TMV033 & 80,0 & Tótkomlós 3-105 & 6024,0 & 910,0 & 646,6 & 4,62 & 7580,6 \\
\hline TMV037 & 82,0 & Szarvas & 2070,0 & 118,2 & 80,4 & - & 2268,6 \\
\hline TMV024 & 82,0 & Domaszék 5-159 & 12,9 & 8,5 & 0,0 & - & 21,4 \\
\hline TMV025 & 82,0 & Domaszék 5-43 & 18,1 & 511,9 & 73,2 & 0,00 & 603,2 \\
\hline TMV029 & 84,0 & Szeged, 5-209 & 3674,0 & 2953,4 & 220,2 & 46,46 & 6847,6 \\
\hline TMV028 & 84,5 & Szeged 5-94 & 133,2 & 7,6 & 1,5 & - & 142,3 \\
\hline TMV039 & 91,0 & Gyula & 1962,0 & 310,0 & 85,0 & - & 2357,0 \\
\hline TMV040 & 95,0 & Orosháza & 5334,0 & 2944,0 & 396,0 & 5,91 & 8674,0 \\
\hline TMV036 & 96,5 & Szarvas 3-263 & 6062,0 & 1746,0 & 23,2 & 17,43 & 7831,2 \\
\hline TMV023 & 99,0 & Zalakaros & 21700,0 & 7653,8 & 377,7 & - & 29731,5 \\
\hline
\end{tabular}

10. táblázat. PAH vegyületcsoportok mennyisége ( $\mu g / l)$, és a fenantrén/antracén aránya (f/a) a hévizekben. 


\begin{tabular}{|c|c|c|c|c|c|c|c|}
\hline Eredeti jelölés & Vízhőm. & mintavétel helye & fenol & F1 & F2 & F3 & összes fenol \\
\hline TMV027 & 38,0 & Szeged & 0,0 & 0,0 & 0,0 & 0,0 & 0,0 \\
\hline TMV020 & 44,0 & Sarkad & 0,0 & 0,0 & 0,0 & 0,0 & 0,0 \\
\hline TMV015 & 46,2 & Kiskunhalas & 0,0 & 0,0 & 0,0 & 0,0 & 0,0 \\
\hline TMV007 & 48,0 & Hajdúszoboszló & 0,0 & 0,0 & 0,0 & 0,0 & 0,0 \\
\hline TMV012 & 50,0 & Eger & 0,0 & 0,0 & 0,0 & 0,0 & 0,0 \\
\hline TMV009 & 56,0 & Berekfürdő & 0,0 & 0,0 & 0,0 & 0,0 & 0,0 \\
\hline TMV034 & 56,0 & Algyő 5-261 & 0,0 & 0,0 & 0,0 & 0,0 & 0,0 \\
\hline TMV022 & 58,0 & Zalaegerszeg & 0,0 & 0,0 & 0,0 & 0,0 & 0,0 \\
\hline TMV038 & 59,0 & Gyula & 0,0 & 0,0 & 0,0 & 0,0 & 0,0 \\
\hline TMV011 & 61,5 & Füzesgyarmat & 0,0 & 0,0 & 0,0 & 0,0 & 0,0 \\
\hline TMV017 & 62,0 & Szolnok & 0,0 & 0,0 & 0,0 & 0,0 & 0,0 \\
\hline TMV031 & 63,0 & Szolnok, 15-93 & 0,0 & 0,0 & 14,8 & 3,7 & 21,7 \\
\hline TMV005 & 65,0 & Babócsa & 0,0 & 0,0 & 0,0 & 0,0 & 0,0 \\
\hline TMV035 & 66,0 & Algyő 5-262 & 0,0 & 0,0 & 0,0 & 0,0 & 0,0 \\
\hline TMV010 & 66,0 & Földes K-29 & 0,0 & 8,0 & 4,9 & 0,0 & 12,9 \\
\hline TMV013 & 68,0 & Egerszalók & 0,0 & 0,0 & 0,0 & 0,0 & 0,0 \\
\hline TMV004 & 69,5 & Lenti & 0,0 & 0,0 & 50,2 & 12,2 & 62,4 \\
\hline TMV026 & 70,0 & Szeged & 79,5 & 11,9 & 11,2 & 0,0 & 102,6 \\
\hline TMV030 & 70,0 & Ásotthalom & 325,8 & 222,3 & 111,0 & 52,8 & 711,9 \\
\hline TMV032 & 70,0 & Végegyháza & 1138,4 & 1666,2 & 352,6 & 71,4 & 3232,4 \\
\hline TMV008 & 70,0 & Hajdúszoboszló & 0,0 & 10,6 & 63,6 & 12,7 & 86,9 \\
\hline TMV019 & 72,0 & Nagybánhegyes & 27,5 & 365,8 & 336,0 & 62,0 & 898,5 \\
\hline TMV042 & 73,5 & Hódmezőv. & 11,0 & 0,0 & 0,0 & 0,0 & 11,0 \\
\hline TMV021 & 76,0 & Deszk & 1626,3 & 2063,9 & 871,2 & 208,1 & 4906,0 \\
\hline TMV041 & 76,0 & Makó & 0,0 & 0,0 & 22,3 & 4,3 & 26,6 \\
\hline TMV014 & 77,0 & Csengele & 0,0 & 38,5 & 0,0 & 0,0 & 38,5 \\
\hline TMV016 & 79,0 & Öcsöd & 1069,9 & 915,4 & 150,7 & 28,3 & 2176,3 \\
\hline TMV033 & 80,0 & Tótkomlós 3-105 & 1210,8 & 1293,3 & 370,5 & 116,9 & 2997,1 \\
\hline TMV037 & 82,0 & Szarvas & 2453,7 & 2345,5 & 932,7 & 231,3 & 5991,2 \\
\hline TMV024 & 82,0 & Domaszék 5-159 & 1218,4 & 1725,7 & 689,7 & 175,4 & 3900,5 \\
\hline TMV025 & 82,0 & Domaszék 5-43 & 343,3 & 508,2 & 185,4 & 25,8 & 1102,9 \\
\hline TMV029 & 84,0 & Szeged, 5-209 & 0,0 & 109,9 & 696,0 & 181,3 & 1105,8 \\
\hline TMV028 & 84,5 & Szeged 5-94 & 1538,0 & 805,2 & 770,3 & 197,4 & 3420,5 \\
\hline TMV039 & 91,0 & Gyula & 0,0 & 370,6 & 850,0 & 306,7 & 1570,5 \\
\hline TMV040 & 95,0 & Orosháza & 1267,5 & 1283,1 & 397,8 & 119,6 & 3074,5 \\
\hline TMV036 & 96,5 & Szarvas 3-263 & 2039,1 & 2841,6 & 601,8 & 124,3 & 5611,2 \\
\hline TMV023 & 99,0 & Zalakaros & 235,7 & 58,8 & 0,0 & 0,0 & 294,5 \\
\hline
\end{tabular}

11. táblázat. Fenol vegyületcsoportok mennyisége ( $\mu \mathrm{g} / \mathrm{l})$ a hévizekben. 


\begin{tabular}{|c|c|c|c|c|c|c|c|c|}
\hline $\begin{array}{c}\text { Minta } \\
\text { (azonosító) }\end{array}$ & Terület & $\begin{array}{c}\mathrm{T} \\
\left({ }^{\circ} \mathrm{C}\right)\end{array}$ & $\begin{array}{l}\text { Mélység } \\
\text { (m) }\end{array}$ & $\begin{array}{c}\delta^{18} \mathrm{O} \\
(\% \text { vsmow })\end{array}$ & $\begin{array}{c}\delta \mathrm{D} \\
\left(\% \mathrm{vSSM}^{\mathrm{V}}\right)\end{array}$ & $\mathrm{pH}$ & $\begin{array}{c}\text { TOC } \\
(\mathrm{mg} / \mathrm{l})\end{array}$ & $\begin{array}{c}\mathrm{I}^{-} \\
(\mathrm{mg} / \mathrm{l})\end{array}$ \\
\hline Szeged (27) & MH & 38 & 585 & $-12,9$ & -93 & 8,17 & 2,4 & 0,014 \\
\hline Sarkad (20) & $\mathrm{Bm}$ & 44 & 1360 & $-11,0$ & -78 & 7,82 & 25 & 0,08 \\
\hline Kiskunhalas (15) & MH & 46,2 & 779 & $-9,5$ & -78 & 8,24 & 13,9 & 3,3 \\
\hline Hajdúszob, (7) & Hsz & 48 & 610,75 & $-7,4$ & -59 & 8,5 & 39 & 2,2 \\
\hline Eger (12) & $\mathrm{E}$ & 50 & 823 & $-10,5$ & -73 & 7,06 & 0,7 & 0,019 \\
\hline Karcag (9) & Já & 56 & 907 & $-8,1$ & -72 & 8,17 & 17,7 & 2,6 \\
\hline Algyő (34) & MH & 56 & 1148 & $-11,8$ & -96 & 8 & 5,2 & 0,14 \\
\hline Zalaeg, (22) & Z & 58 & 1703 & $-12,4$ & -86 & 6,95 & 1,5 & 0,4 \\
\hline Gyula (38) & $\mathrm{Bm}$ & 59 & 1520,5 & $-10,2$ & -82 & 7,54 & 33 & 0,38 \\
\hline Füzesgy, (11) & $\mathrm{Bm}$ & 61,5 & 924,5 & $-8,8$ & -74 & 8,33 & 11,7 & 1,2 \\
\hline Szolnok (17) & Já & 62 & 1071,25 & $-8,3$ & -71 & 8,76 & 26 & 3,4 \\
\hline Szolnok (31) & Já & 63 & 1048,45 & $-8,2$ & -66 & 7,3 & 29 & 3,2 \\
\hline Babócsa (5) & Dm & 65 & 1065 & $-9,4$ & -76 & 7,99 & 13,5 & 0,24 \\
\hline Algyő (35) & MH & 66 & 1416,5 & $-12,2$ & -95 & 8,03 & 5,3 & 0,16 \\
\hline Földes (10) & Hsz & 66 & 1117 & $-0,9$ & -31 & 7,78 & 13,5 & 8,7 \\
\hline Egerszalók (13) & $\mathrm{E}$ & 68 & 411,5 & $-10,8$ & -84 & 6,79 & 0,5 & 0,03 \\
\hline Lenti (4) & MH & 69,5 & 1340,9 & $-12,0$ & -95 & 6,92 & 5 & 0 \\
\hline Szeged (26) & MH & 70 & 1431 & $-12,4$ & -89 & 7,94 & 8,2 & 0,098 \\
\hline Ásotthalom (30) & MH & 70 & 1085 & $-5,6$ & -53 & 7,57 & 122 & 7,8 \\
\hline Végegyháza (32) & $\mathrm{Ph}$ & 70 & 967,5 & $-7,2$ & -73 & 7,44 & 118 & 2 \\
\hline Hajdúszob, (8) & Hsz & 70 & 1050 & $-3,4$ & -41 & 8,06 & 21 & 8,5 \\
\hline Nagybánh, (19) & $\mathrm{Ph}$ & 72 & 1126,5 & $-6,3$ & -59 & 8,22 & 47 & 2,6 \\
\hline Hódmezőv, (42) & MH & 73,5 & 1915,5 & $-12,0$ & -93 & 7,76 & 12,2 & 0,071 \\
\hline Deszk (21) & MH & 76 & 1668,5 & $-11,1$ & -95 & 7,85 & 106 & 0,1 \\
\hline Makó (41) & MH & 76 & 1653 & $-11,9$ & -91 & 7,81 & 60 & 0,15 \\
\hline Csengele (14) & MH & 77 & 1570,5 & $-11,5$ & -87 & 8,03 & 4,5 & 0,1 \\
\hline Öcsöd (16) & $\mathrm{Bm}$ & 79 & 1502,25 & $-12,0$ & -96 & 7,71 & 16,7 & 0,04 \\
\hline Tótkomlós (33) & $\mathrm{Ph}$ & 80 & 1243,5 & $-5,9$ & -48 & 8,13 & 360 & 2,4 \\
\hline Szarvas (37) & $\mathrm{Bm}$ & 82 & 1774 & $-5,9$ & -75 & 8,24 & 630 & 3,8 \\
\hline Domaszék (24) & MH & 82 & 1642,5 & $-9,2$ & -82 & 8,47 & 450 & 3 \\
\hline Szeged (25) & MH & 82 & 1688,5 & $-12,8$ & -87 & 7,97 & 31 & 0,098 \\
\hline Szeged (29) & MH & 84 & 1606,5 & $-12,3$ & -95 & 8,47 & 89 & 0,098 \\
\hline Szeged (28) & MH & 84,5 & 1654 & $-12,3$ & -93 & 8,4 & 112 & 0,14 \\
\hline Gyula (39) & $\mathrm{Bm}$ & 91 & 2181 & $-5,1$ & -69 & 8,14 & 750 & 2,8 \\
\hline Orosháza (40) & $\mathrm{Ph}$ & 95 & 1547 & $-4,4$ & -71 & 8,14 & 800 & 4,8 \\
\hline Szarvas (36) & $\mathrm{Bm}$ & 96,5 & 1658,5 & $-10,7$ & -91 & 7,92 & 2,72 & 0,7 \\
\hline Zalakaros (23) & $\mathrm{Z}$ & 99 & 2263,5 & 1,0 & -45 & 7,13 & 9,1 & 6,1 \\
\hline
\end{tabular}

12. táblázat. A vizsgált hévizek fontos paraméterei a növekvő hömérséklet szerint sorba rendezve. A hömérséklet kifolyási hömérsékletet jelent, a mélység pedig a szüröközép mélységét. Területek: Bm: Békési-medence, Dm: Dráva-medence, E: Eger, Hsz: Hajdúszoboszló, Já: Jászság, MH: Makó-Hódmezővásárhelyi -árok, Ph: Pusztaföldvári-hát, Z: Zalai-medence. 


\begin{tabular}{|c|c|c|c|c|c|c|c|c|c|c|}
\hline $\begin{array}{c}\text { Minta } \\
\text { (azonosító) }\end{array}$ & Terület & $\begin{array}{c}\mathrm{T} \\
\left({ }^{\circ} \mathrm{C}\right)\end{array}$ & $\begin{array}{l}\text { Mélység } \\
(\mathrm{m})\end{array}$ & $\begin{array}{l}\mathrm{Na}^{+} \\
(\mathrm{mg} / \mathrm{l})\end{array}$ & $\begin{array}{c}\mathrm{K}^{+} \\
(\mathrm{mg} / \mathrm{l})\end{array}$ & $\begin{array}{l}\mathrm{Ca}^{2+} \\
(\mathrm{mg} / \mathrm{l})\end{array}$ & $\begin{array}{l}\mathrm{Mg}^{2+} \\
(\mathrm{mg} / \mathrm{l})\end{array}$ & $\begin{array}{r}\mathrm{HCO}_{3}{ }^{-} \\
(\mathrm{mg} / \mathrm{l})\end{array}$ & $\underset{(\mathrm{mg} / \mathrm{l})}{\mathrm{Cl}^{-}}$ & $\begin{array}{l}\mathrm{SO}_{4}{ }^{2-} \\
(\mathrm{mg} / \mathrm{l})\end{array}$ \\
\hline Szeged (27) & $\mathrm{MH}$ & 38 & 585 & 165 & 0,91 & 4,76 & 1,99 & 318 & 2,8 & 0,67 \\
\hline Sarkad (20) & $\mathrm{Bm}$ & 44 & 1360 & 574 & 4,4 & 11,9 & 4,21 & 1543 & 20,1 & 2,81 \\
\hline Kiskunhalas (15) & MH & 46,2 & 779 & 606 & 2,49 & 5,12 & 3,36 & 1458 & 116 & 2,25 \\
\hline Hajdúszob, (7) & Hsz & 48 & 610,75 & 564 & 2,37 & 3,96 & 1,34 & 1146 & 155 & 2,13 \\
\hline Eger (12) & E & 50 & 823 & 27,1 & 4,38 & 131 & 18,1 & 462 & 27,3 & 43 \\
\hline Karcag (9) & Já & 56 & 907 & 850 & 6,21 & 16,6 & 4,95 & 1476 & 461 & 1,67 \\
\hline Algyő (34) & MH & 56 & 1148 & 318 & 2,06 & 3,96 & 1,53 & 573 & 57,6 & 1,26 \\
\hline Zalaeg, (22) & Z & 58 & 1703 & 103 & 10,1 & 82,1 & 20,3 & 404 & 112 & 35,7 \\
\hline Gyula (38) & $\mathrm{Bm}$ & 59 & 1520,5 & 597 & 5,79 & 11,8 & 3,42 & 1238 & 98 & 4,34 \\
\hline Füzesgy, (11) & $\mathrm{Bm}$ & 61,5 & 924,5 & 487 & 3,24 & 5,16 & 1,32 & 1048 & 90,7 & 1,54 \\
\hline Szolnok (17) & Já & 62 & 1071,25 & 3020 & 38 & 8,6 & 2,84 & 5203 & 1009 & 2,9 \\
\hline Szolnok (31) & Já & 63 & 1048,45 & 2500 & 119 & 51 & 15,4 & 5935 & 716 & 4,7 \\
\hline Babócsa (5) & Dm & 65 & 1065 & 465 & 4,48 & 5,07 & 1,9 & 1244 & 15,7 & 2,45 \\
\hline Algyő (35) & MH & 66 & 1416,5 & 386 & 3,2 & 3,37 & 0,88 & 793 & 61,3 & 1,68 \\
\hline Földes (10) & Hsz & 66 & 1117 & 4380 & 28,2 & 180 & 57,8 & 361 & 7046 & 2,35 \\
\hline Egerszalók (13) & E & 68 & 411,5 & 58 & 9,21 & 151 & 22,2 & 398 & 26,9 & 66,7 \\
\hline Lenti (4) & MH & 69,5 & 1340,9 & 362 & 4,85 & 4,31 & 0,82 & 1007 & 4,1 & 2,17 \\
\hline Szeged (26) & MH & 70 & 1431 & 553 & 4,44 & 4,29 & 0,98 & 1397 & 54,3 & 2,74 \\
\hline Ásotthalom (30) & MH & 70 & 1085 & 2380 & 44 & 24,4 & 6,8 & 4166 & 1268 & 32,1 \\
\hline Végegyháza (32) & $\mathrm{Ph}$ & 70 & 967,5 & 920 & 9,34 & 4,73 & 1,76 & 1983 & 188 & 20,2 \\
\hline Hajdúszob, (8) & Hsz & 70 & 1050 & 1300 & 9,11 & 8,26 & 2,7 & 1175 & 988 & 3,67 \\
\hline Nagybánh, (19) & $\mathrm{Ph}$ & 72 & 1126,5 & 954 & 5,87 & 4,73 & 2,11 & 1922 & 232 & 26,5 \\
\hline Hódmezőv, (42) & MH & 73,5 & 1915,5 & 576 & 6,12 & 4,16 & 1,02 & 1525 & 39,9 & 3,81 \\
\hline Deszk (21) & MH & 76 & 1668,5 & 1150 & 10,9 & 4,82 & 1,35 & 2934 & 55,5 & 16,9 \\
\hline Makó (41) & MH & 76 & 1653 & 614 & 6,53 & 4,53 & 1,27 & 1495 & 59,6 & 4,22 \\
\hline Csengele (14) & MH & 77 & 1570,5 & 281 & 4,56 & 4,56 & 0,37 & 689 & 56,6 & 2,29 \\
\hline Öcsöd (16) & $\mathrm{Bm}$ & 79 & 1502,25 & 413 & 8,02 & 4,55 & 0,61 & 1122 & & 4,95 \\
\hline Tótkomlós (33) & $\mathrm{Ph}$ & 80 & 1243,5 & 1040 & 8,41 & 2,92 & 1,45 & 2019 & 230 & 32,4 \\
\hline Szarvas (37) & $\mathrm{Bm}$ & 82 & 1774 & 1490 & 25,5 & 11,2 & 1,8 & 3007 & 386 & 40,2 \\
\hline Domaszék (24) & MH & 82 & 1642,5 & 1310 & 19 & 10,8 & 2,43 & 2604 & 375 & 17,9 \\
\hline Szeged (25) & MH & 82 & 1688,5 & 795 & 7,95 & 4,36 & 0,96 & 2044 & 43 & 5,74 \\
\hline Szeged (29) & MH & 84 & 1606,5 & 950 & 12 & 5,2 & 1,57 & 2299 & 14,1 & 5,32 \\
\hline Szeged (28) & MH & 84,5 & 1654 & 928 & 11,2 & 5,4 & 1,4 & 2079 & 18,3 & 5,11 \\
\hline Gyula (39) & $\mathrm{Bm}$ & 91 & 2181 & 1580 & 21 & 4,5 & 1,75 & 2483 & 200 & 42,6 \\
\hline Orosháza (40) & $\mathrm{Ph}$ & 95 & 1547 & 1650 & 22,4 & 8,3 & 2,19 & 3276 & 595 & 44,9 \\
\hline Szarvas (36) & $\mathrm{Bm}$ & 96,5 & 1658,5 & 990 & 14,1 & 5,58 & 1,42 & 2397 & 86,9 & 36,9 \\
\hline Zalakaros (23) & $\mathrm{Z}$ & 99 & 2263,5 & 2980 & 46,9 & 122 & 25,7 & 2074 & 3773 & 29,1 \\
\hline
\end{tabular}

13. táblázat. A vizsgált hévizek föionos összetétele a növekvö hömérséklet szerint sorba rendezve. A hömérséklet kifolyási hömérsékletet jelent, a mélység pedig a szüröközép mélységét. Területek: Bm: Békési-medence, Dm: Dráva-medence, E: Eger, Hsz:

Hajdúszoboszló, Já: Jászság, MH: Makó-Hódmezövásárhelyi-árok, Ph: Pusztaföldvári-hát, Z: Zalai-medence. 


\subsubsection{A hévizek szervetlen kémiai paraméterei}

A hévizek stabilizotópos összetétele látható a 8. ábrán. Az ábrázolt csapadékvíz-vonal (illetve a holocén és pleisztocén rétegvíz-vonal) egyenlete:

$$
\delta \mathrm{D}=7,8 * \delta^{18} \mathrm{O}+6
$$

Deák (1995) szerint.

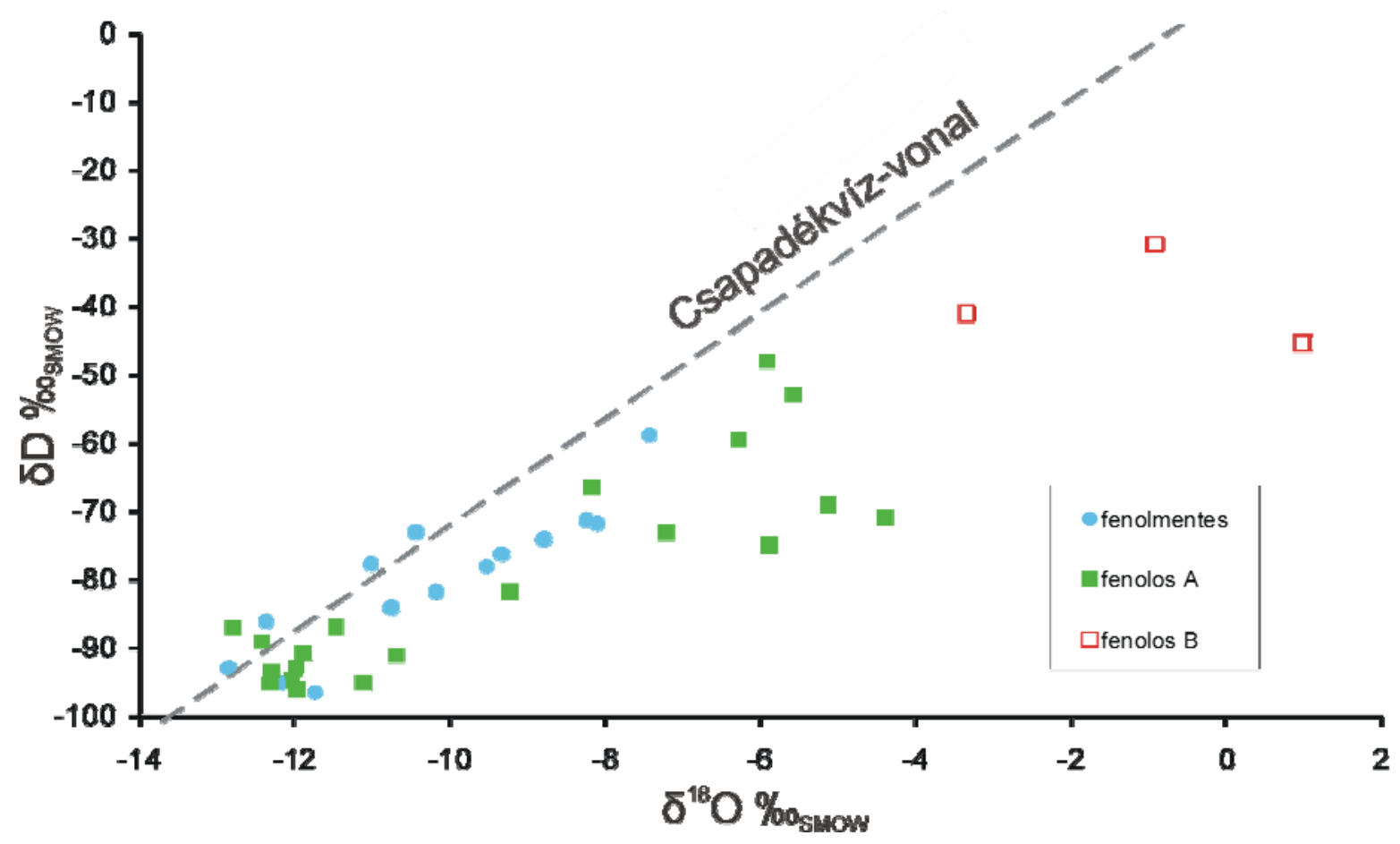

8. ábra. A hévizek stabilizotópos összetétele

A fenolos és fenolt nem tartalmazó vizek nem különülnek el egymástól élesen. Figyelemre méltó azonban, hogy a tengervízhez közelebb elhelyezkedő minták ( $\left(\delta^{18} \mathrm{O}>-7,5 \%\right)$ mind az érettebb csoportba tartoznak. Ezek a vizek mind elérik vagy megközelítik a szerves anyagból való aromás képződés alsó hőmérsékleti határának tekintett $\sim 70^{\circ} \mathrm{C}$ kifolyó vízhőmérsékletet (9. ábra). A fenolos B csoportba tartoznak az izotóposan legnehezebb vizek. 


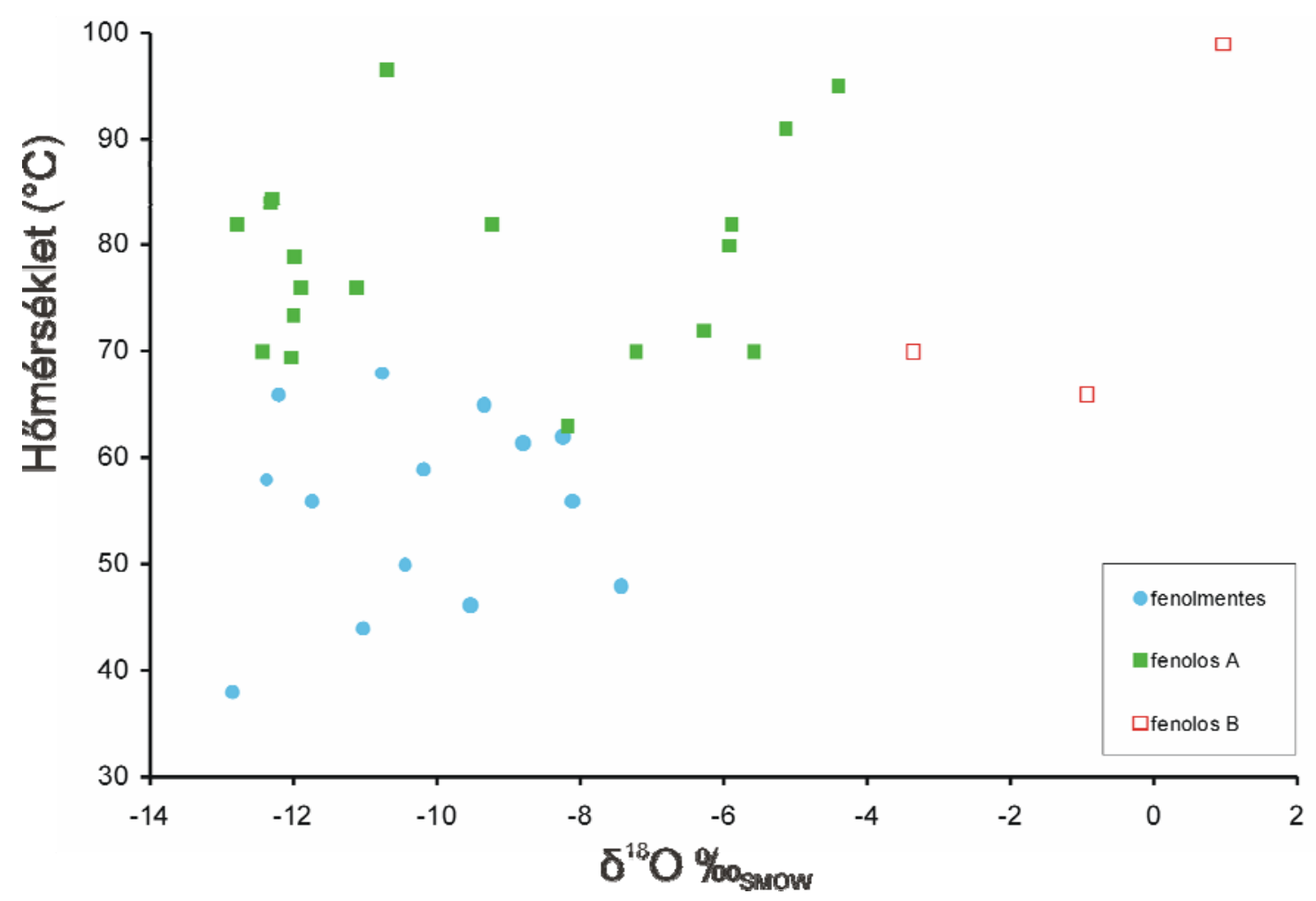

9. ábra. Az öt hévízcsoport hömérséklete és oxigénizotópos összetétele

A 10. ábrán Vető et al. (2004b) eredményeihez hasonló eloszlást láthatunk a HCO3- és a $\mathrm{Na}+$ /HCO3- koncentrációk tekintetében, kiegészítve a vizek fenoltartalom szerinti csoportosításával.
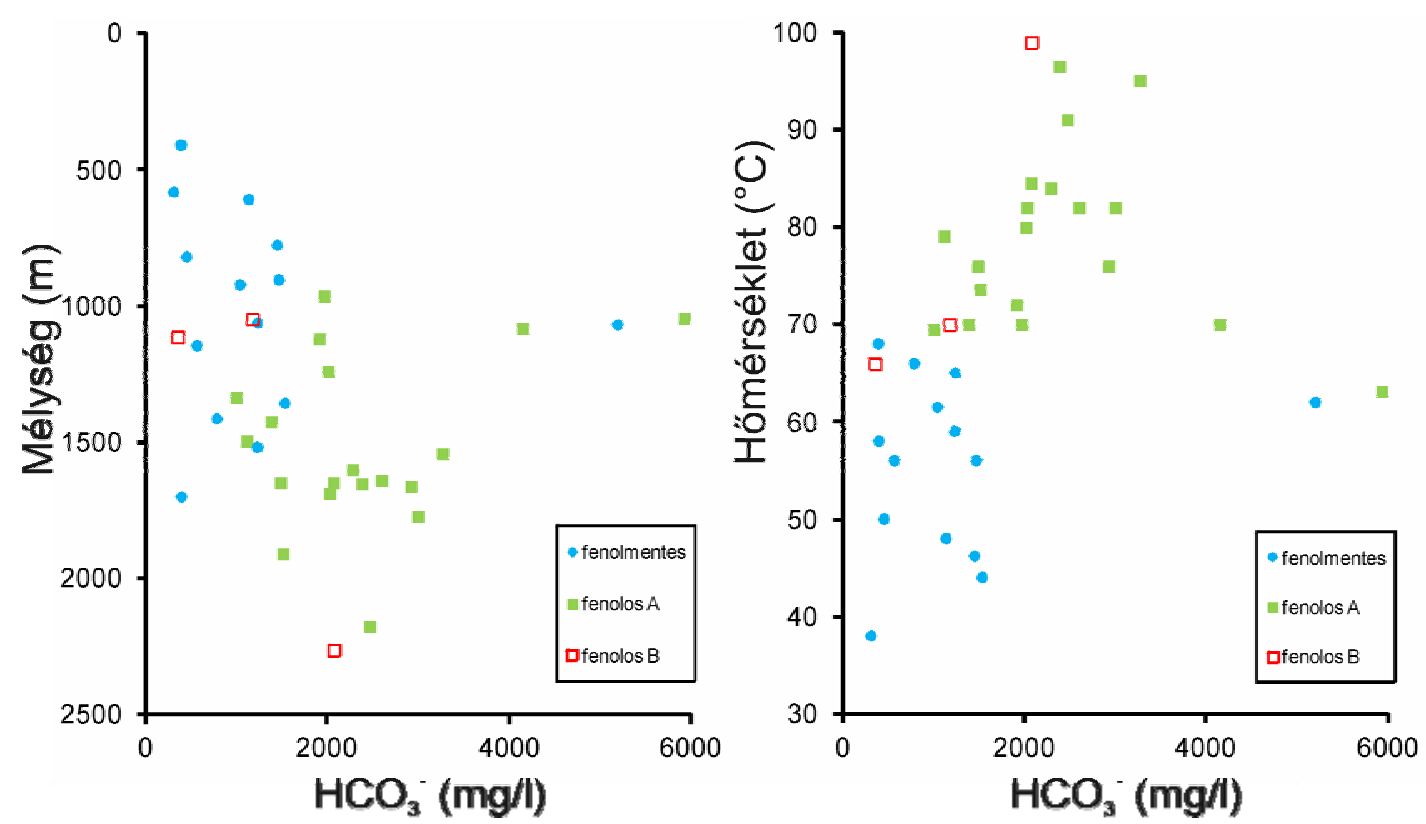

10. ábra. HCO3-tartalom változása a mélység és a hömérséklet függvényében. 
Bár a hidrogén-karbonát mennyisége nem szigorúan függ össze a mélységgel, valamint nem ismerjük a vizek előéletét sem (azaz helyzetüket az áramlási útjuk során), de a 10. ábrán egyértelműen látható, hogy a mélyebbről származó vizek nagyobb arányban tartalmaznak sok oldott karbonátot.

A 1500 mg/l-töl nagyobb mennyiségü oldott hidrogén-karbonátot - egyetlen kivétellel csak a fenol tartalmú vizek tartalmaznak. Ez azt mutatja, hogy oldott karbonát mennyiségét jelentősen befolyásolja az érett szerves anyag jelenléte, azáltal, hogy a szerves anyag bomlásából származó $\mathrm{CO}_{2}$ bekerül a felszín alatti vízbe, és fokozza a kőzetekben (akár cementáló anyagként) előforduló karbonát oldódását. Emellett a szerves anyagok bomlása együtt jár az aromás szénhidrogének, és szénhidrogén gázok (Vető et al., 1994; Fekete et al., 2009, 2010) keletkezésével.

A keletkező széndioxid a földpátok és csillámok bomlását is elősegíti. Ha megvizsgáljuk a nátrium és kálium koncentrációkat (11. és 12. ábra), látható, hogy a fenolos mintákban ezek általában nagyobbak, mint a bomlott szerves anyagot nem tartalmazó hévizekben. Emellett azonban a kalciumion koncentráció nem mutat összefüggést (növekedést) a szervesanyagéréssel, így az előbb felsorolt ionok kationcseréből, illetve agyagásványok átalakulásából is származhatnak. Ez azt jelenti, hogy a karbonátok oldódásával a vízbe került kalcium agyagásványokon egy vegyértékü ionokra cserélődött.

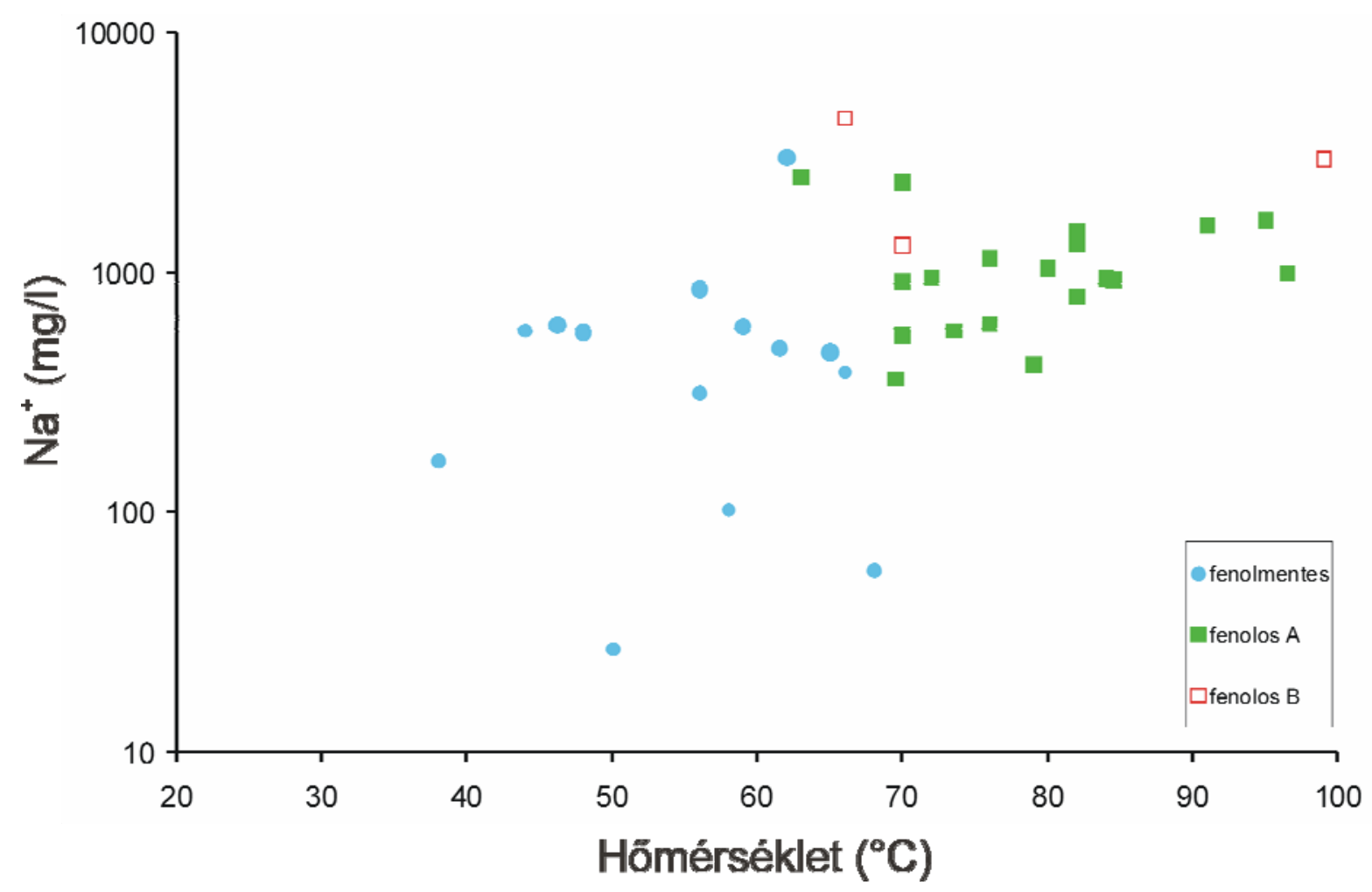

11. ábra. Nátriumion koncentrációk (mg/l) a hömérséklet függvényében. 


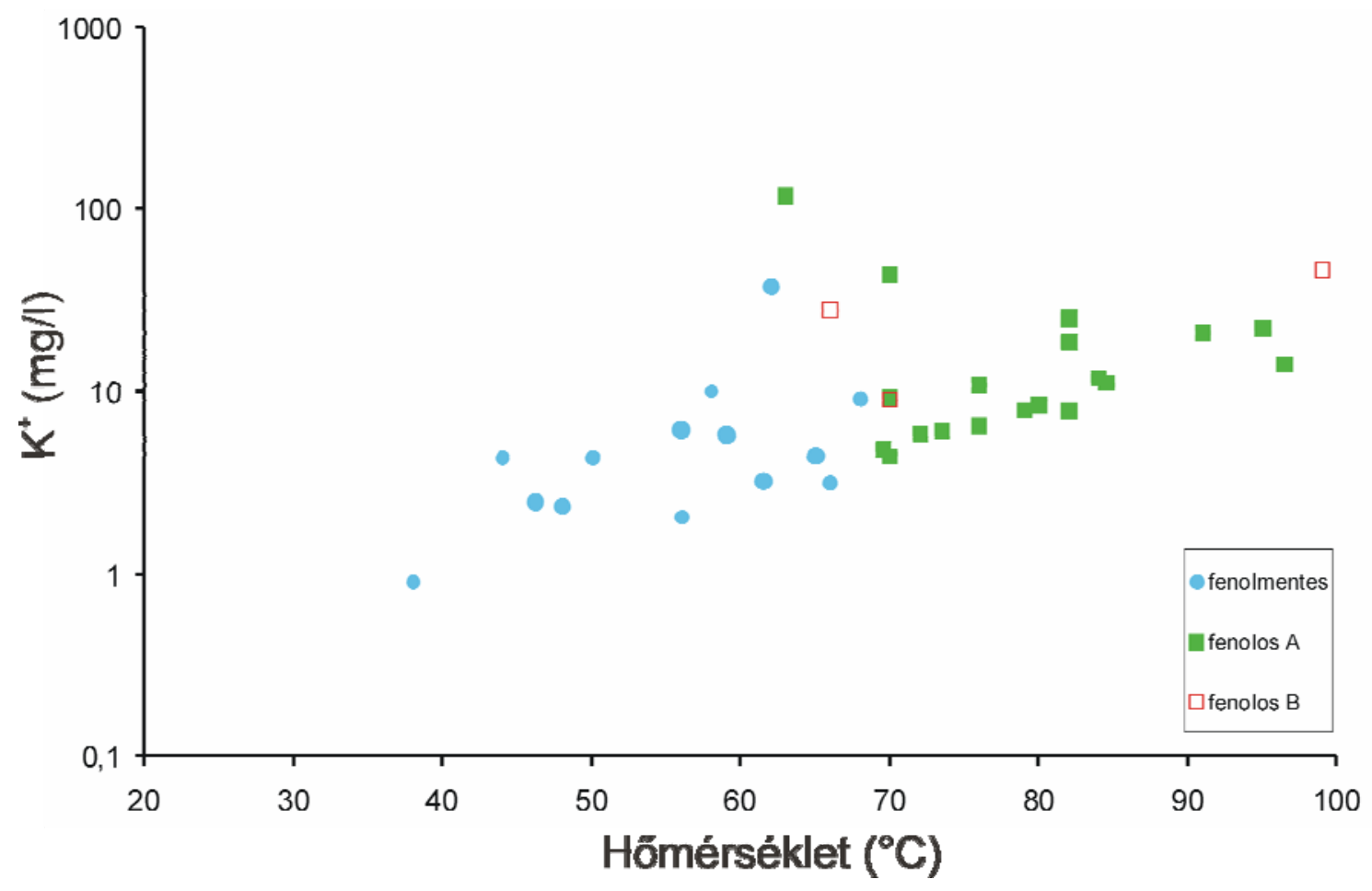

12. ábra. Káliumion koncentrációk (mg/l) a hömérséklet függvényében.

A nátrium és klorid, illetve nátrium és hidrogén-karbonát moláris arányait megvizsgálva látható, hogy a $\delta^{18} \mathrm{O}$ növekedésével a $\mathrm{Na}^{+} / \mathrm{HCO}_{3}{ }^{-}$arány kissé növekszik (13.ábra), a $\mathrm{Na}^{+} / \mathrm{Cl}^{-}$ arány egyértelmüen csökken (14. ábra).

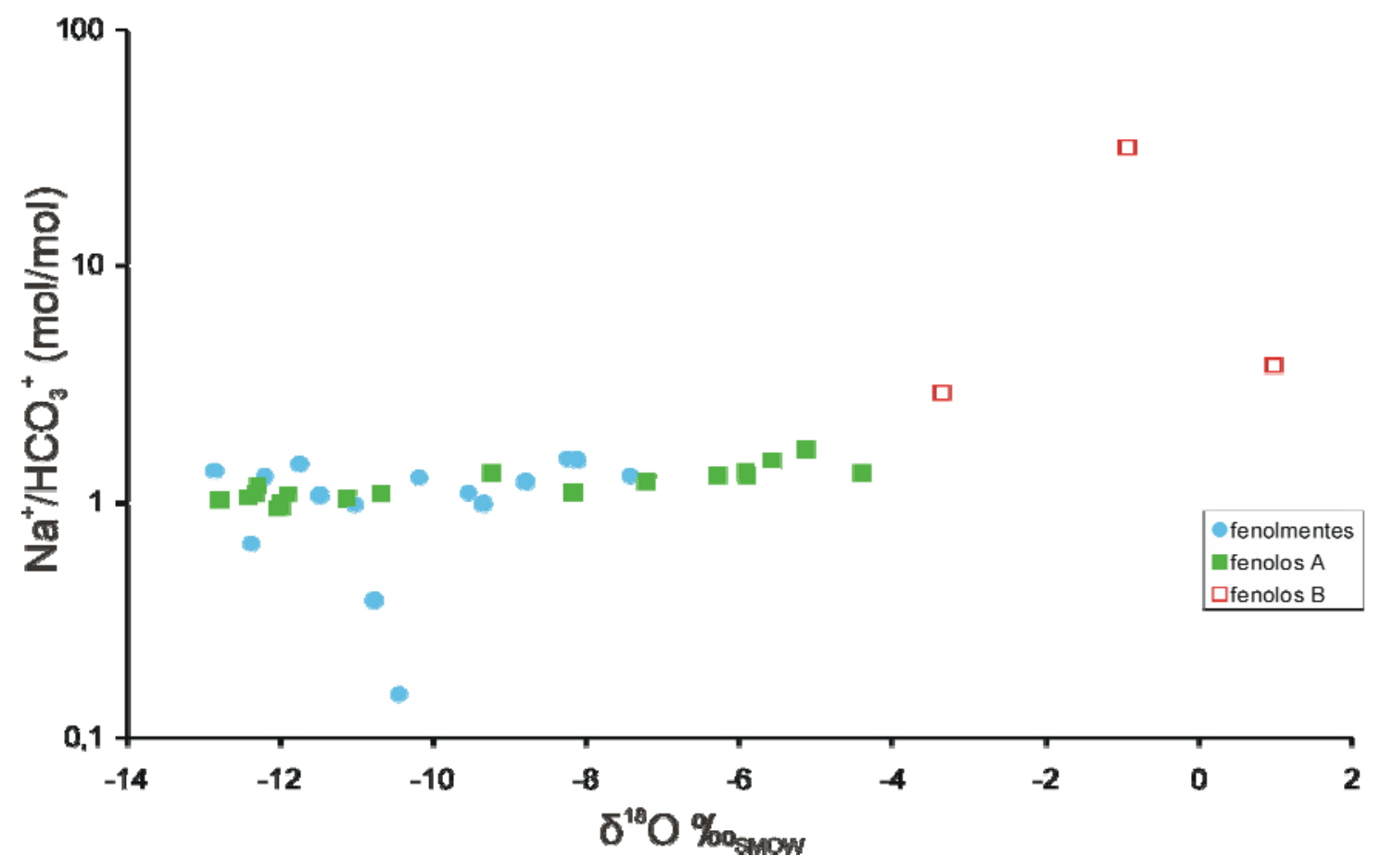

13. ábra. Nátrium és hidrogén-karbonátion moláris aránya az oxigénizotópos összetétel függvényében. 


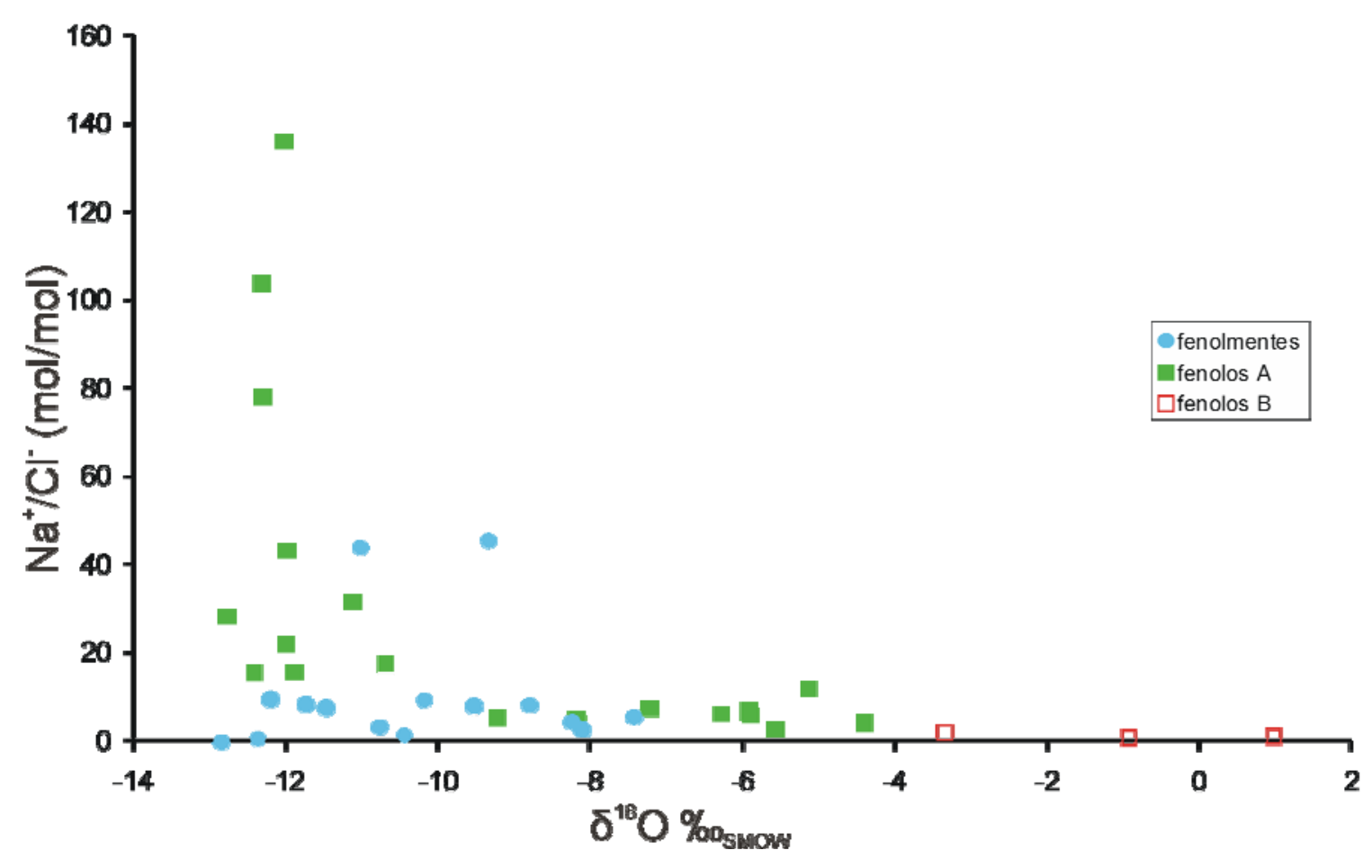

14. ábra. Nátrium és kloridion moláris aránya az oxigénizotópos összetétel függvényében.

A 3 darab, jóval 1 alatti $\mathrm{Na}^{+} / \mathrm{HCO}_{3}{ }^{-}$aránnyal rendelkezö minta esetében a $\mathrm{Ca}^{2+}$-tartalom kiemelkedő, valamint a vízadó réteg is karbonátos kőzetben van. Ezek a minták meleg karsztvizek, amikre nem hatott erős kőzet-víz kölcsönhatás, esetükben nem volt lehetöség nagymértékü földpát vagy csillám átalakulásból vagy bomlásból származó ioncserére vagy dúsulásra. A magyarországi karsztvizek általában nem tartalmaznak érett szerves anyagot (pl. Kárpáti, 1999), és a TOC értékeik is kicsik.

Látható, hogy az egyre kevésbé negatív $\delta^{18} \mathrm{O}$ értékkel jellemezhető vizek egyre közelebb kerülnek a tengervíz 1-hez közeli $\mathrm{Na} / \mathrm{Cl}$ moláris arányához. Bár a kloridtartalom nem lineárisan növekszik a $\delta^{18} \mathrm{O}$ növekedésének függvényében, a $200 \mathrm{mg} / \mathrm{l}$ feletti $\mathrm{Cl}^{-}$-tartalom $-9,2$ $\delta^{18} \mathrm{O}$ érték felett fordul elö, illetve csak a két, 0 -hoz közeli $\delta^{18} \mathrm{O}$ értékhez tartozik kimagaslóan nagy klorid koncentráció. Ez azt mutatja, hogy a meteorikus vizek tartalmazhatnak a kiédesedő tengervízből visszamaradt pórusvíz komponenst.

A másik lehetőség, hogy a korábban beszivárgott, meteorikus eredetű vizek olyan tengeri üledékekkel lépnek kölcsönhatásba, ami a nátrium-klorid tartalmat szolgáltatja, ebben az esetben azonban feltételeznünk kell az üledékek és a víz között lejátszódó oxigén izotóp cserét. 
Mindkét lehetőség összhangban van Tóth és Almási (2001) megállapításával arról, hogy a Pannon-medencében a felszínhez közelebb elhelyezkedő, gravitáció által vezérelt áramlási rendszer és az ez alatt kimutatható túlnyomásos, felfelé áramló rendszer között a kétféle eredetű víz keveredése valószínűsíthető.

A vizek jodidion-tartalma általánosan a szerves anyagok eredetével mutat összefüggést, mivel jódot a tengeri élőlények halmoznak fel nagy koncentrációban (White 1965, Collins, 1975, Hem, 1985). A fenolos és fenolmentes csoport tagjaira egyaránt jellemző lehet a nagy jodidtartalom, a szerves anyag bomlásától függetlenül. Ez a jódtartalmat szolgáltató tengeri élőlények korai, kis hőmérsékleten történő lebomlását mutatja.

Mivel a jodidtartalom a növekvő $\delta^{18} \mathrm{O}$ értékkel növekszik (15. ábra), feltételezhető, hogy az izotóposan kevésbé negatív vizek szerves anyaga nagyobb arányban származik tengeri környezetből, illetve egykori tengeri üledékekből. Meg kell jegyezni, hogy Fuge és Johnson (1986) alapján a kiédesedő Pannon-tóban a sótartalommal a jód koncentráció is csökkent, a jódot nagy mennyiségben megkötő tengeri növényeket vagy algákat édesvízi és szárazföldi növények váltották fel. Ez egybevág Vető et al. (1997) ide vonatkozó megállapításaival.

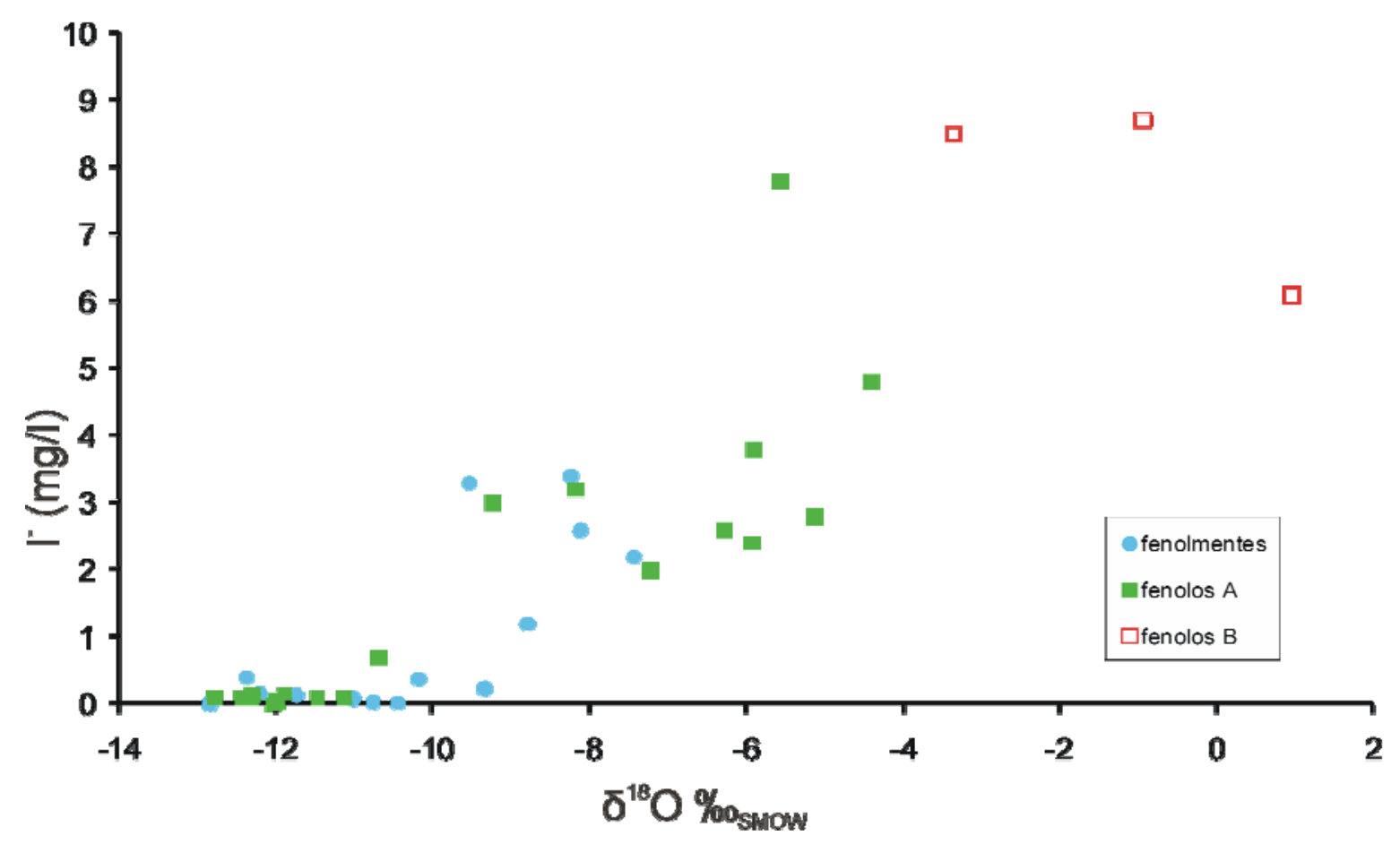

15. ábra. Jodid és az oxigén izotópos összetétel kapcsolata.

Figyelemre méltó a jodid-koncentráció növekedése a növekvő kloridtartalommal (16. ábra). A víz eredetére így sem kapunk választ, de az bizonyos, hogy a mély, meleg vizekhez 
hozzákeveredhet az egykori tengeri szerves anyagot tartalmazó üledékekkel kölcsönhatásba került pórusvize, ami az üledékkel együtt lerakódott és a pórusokba bezáródott víz vagy idős, meteorikus víz is lehet, ami O izotópcserén esett át. Ez a reakció a nagy hőmérsékletek és a geológiai idő miatt lejátszódhatott. Ezzel együtt Vető et al. (2004b) a (0-hoz közeli $\delta^{18} \mathrm{O}$ értékkel jellemezhető) nagy klorid tartalmú vizeket részben az egykori Pannon-tó pórusokba záródott vizének tekinti.

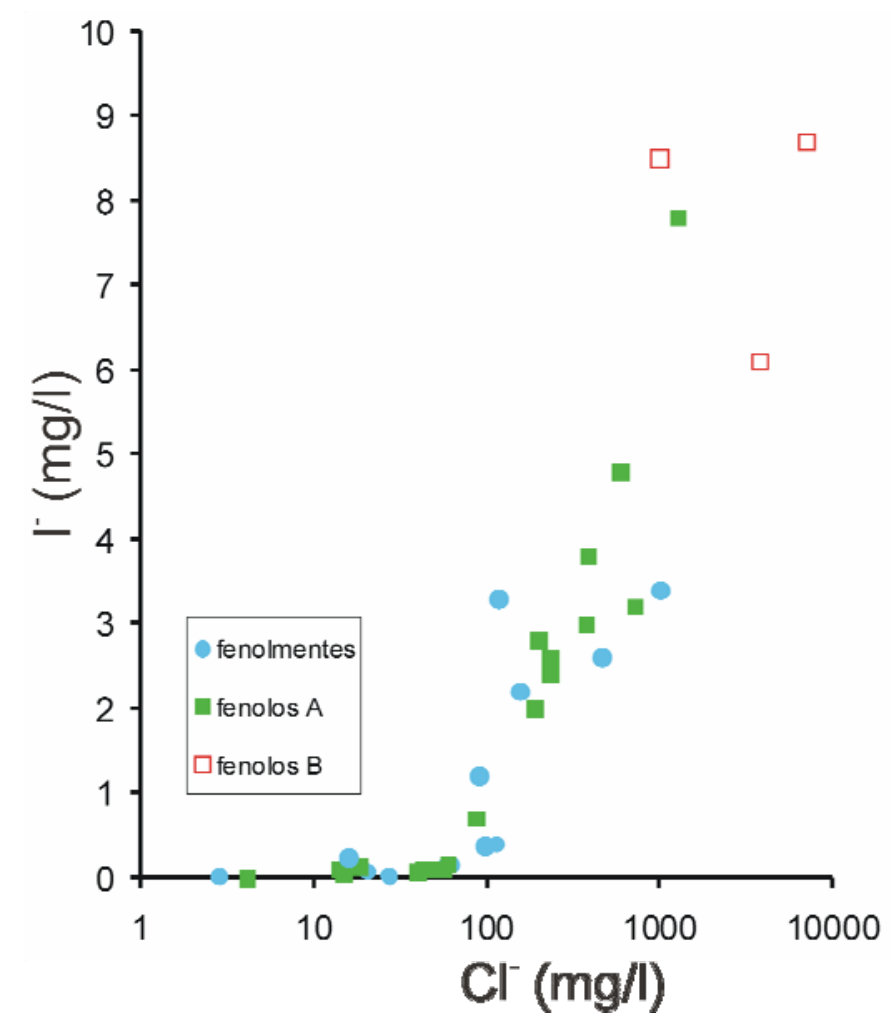

16. ábra. Jodid koncentrációk a klorid koncentrációk függvényében.

Mindenesetre megállapítható, hogy a jelen tanulmányban vizsgált minták esetében a szerves anyag érése és az aromás vegyületek keletkezése csak a küszöbhőmérséklet elérésétől függ, nincs összefüggésben a I--tartalommal, tehát független a kiindulási szerves anyag tengeri vagy szárazföldi eredetétől. 


\subsubsection{Szerves vegyületek a hévizekben}

A hévizekben oldott szerves anyag eredete többféle lehet. Elsőként, a csapadék beszivárgása után, a talajból származó, vízben jól oldódó szerves anyagok (humin anyagok) kerülnek bele a vizekbe, később az üledékek diszperz szerves anyagával, illetve a lokális szerves anyag felhalmozódásokkal (például lignit csíkok, vagy akár kőolajtelepek) találkozhatnak a vándorló felszín alatti vizek, és így az oldott szerves széntartalom eredete és jellege igen változatos lehet.

Az illékony szerves anyag megjelenése a hévizekben hőmérsékleti küszöbhöz kötött, ami alátámasztja a korábbi elképzeléseket az aromás vegyületek megjelenéséről. A hőmérsékleteket feltüntető ábrákon (előző, 4.2.1 fejezet) jól látható a fenolok megjelenése a $\sim 70^{\circ} \mathrm{C}$-os hömérsékleti küszöbérték felett. Meg kell említeni, hogy kifolyási hömérséklet értékekről van szó; a kutak talphőmérséklete ettől $15-30^{\circ} \mathrm{C}-\mathrm{kal}$ nagyobb lehet.

Ha megvizsgáljuk a teljes oldott szerves széntartalmat, akkor látható, hogy mindkét csoportban találunk kisebb és nagyobb TOC tartalmakat (17. ábra). A fenolok megjelenését azonban csak a hőmérséklet határozza meg, a hasonló TOC tartalmú minták közül csak azokban jelenik meg fenol, amelyek hömérséklete a korábban megállapított küszöbértéket meghaladja.

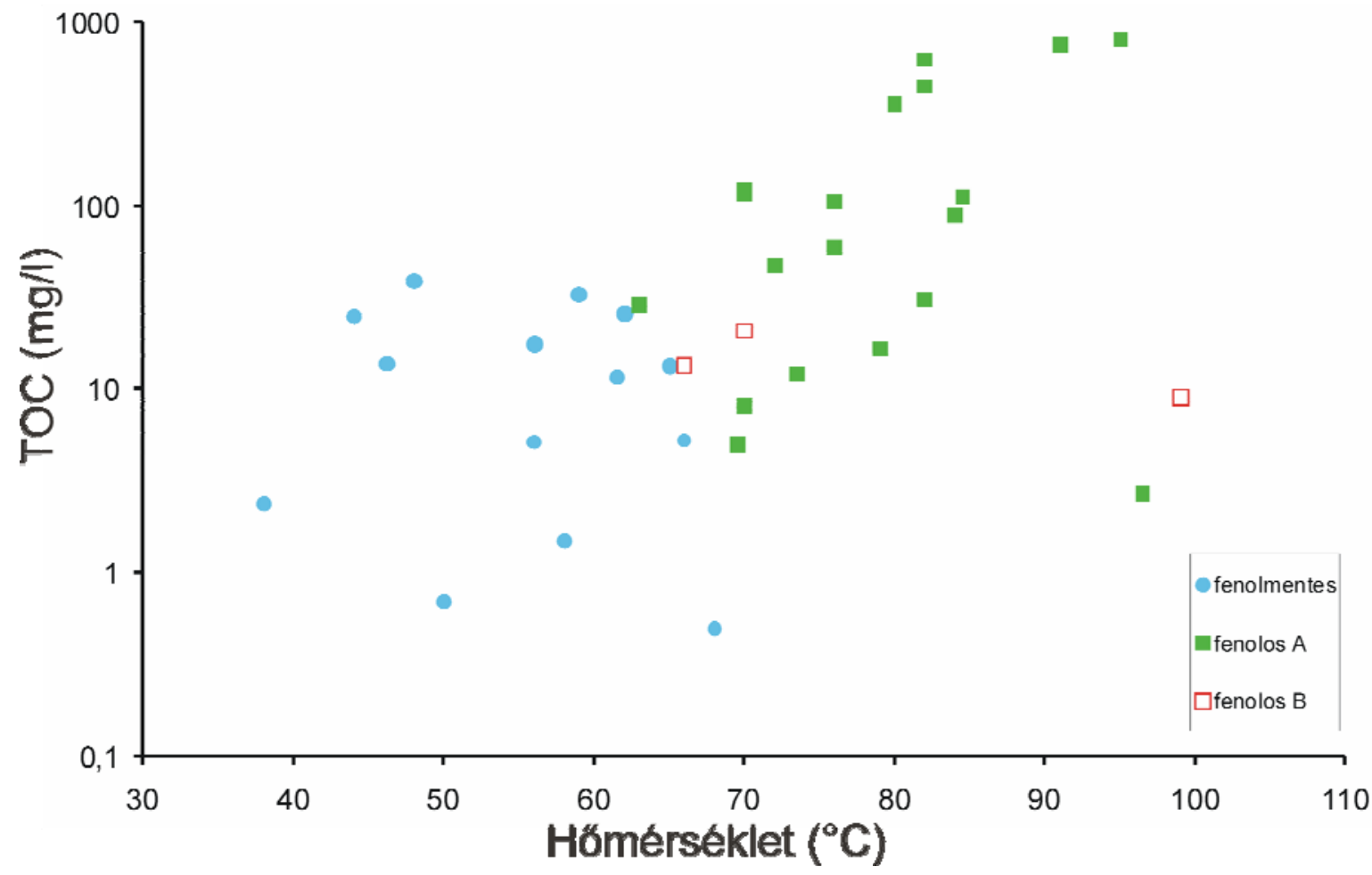

17. ábra. Hömérséklet és TOC összefüggése. 
A korábbi megfigyelésekkel ellentétben (pl. Kárpáti et al., 1999; Sajgó et al., 2007b) az értekezés keretében vizsgált mintapopulációban az aromás vegyületek koncentrációi nem mutatnak szoros összefüggést a hőmérséklettel.

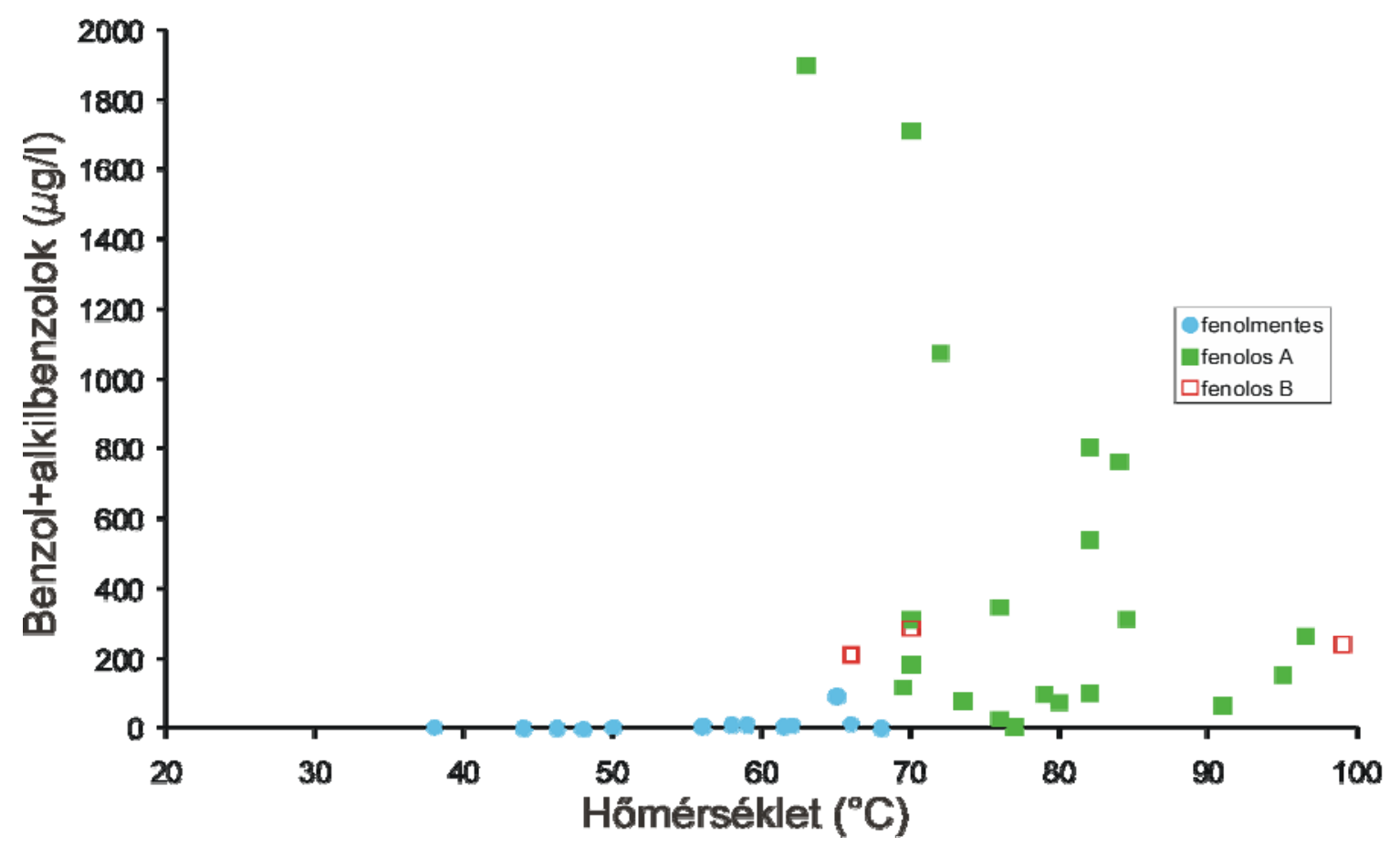

18. ábra. Benzol és alkilbenzolok együttes koncentrációja $(\mu \mathrm{g} / \mathrm{l})$.

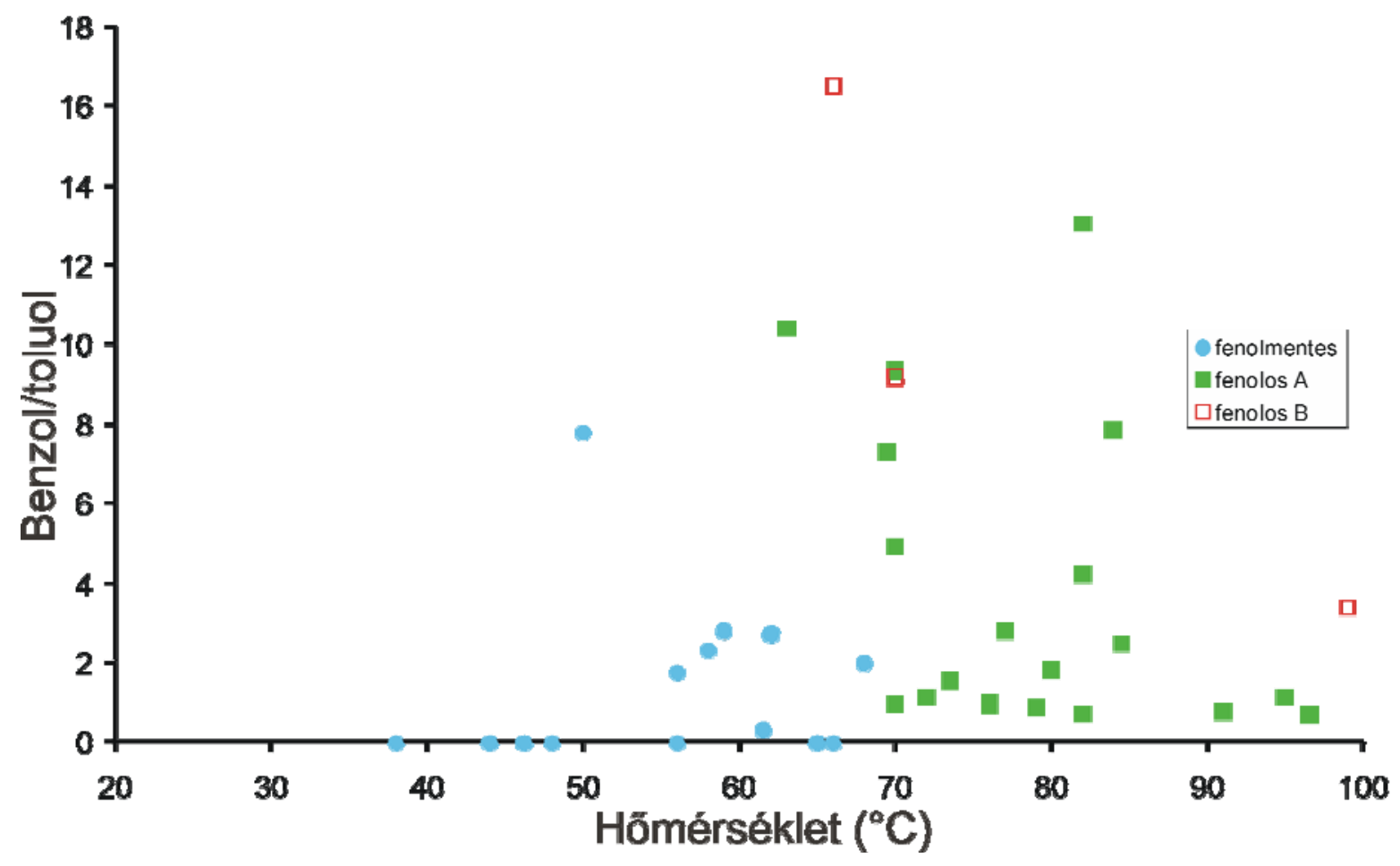

19. ábra. B/t (benzol/toluol) aránya a hömérséklet függvényében. 
A benzol, és a vizsgált alkilbenzol csoportok (toluol, C2, C3, C4) egyaránt jóval nagyobb koncentrációkban figyelhetők meg a fenolos vizekben (18. ábra). A b/t (19. ábra) általában a fenolos csoportban nagyobb, a bt/a és b/a értékek nem nagyon különböznek a két csoportban (9. táblázat).

A PAH-ok nem sokkal jellemzőbbek a fenolos vizekre (20. ábra), a koncentrációk csak kissé magasabbak. Ugyanezt tapasztaljuk, ha a gyürük száma szerinti csoportokat tekintjük (10. táblázat).

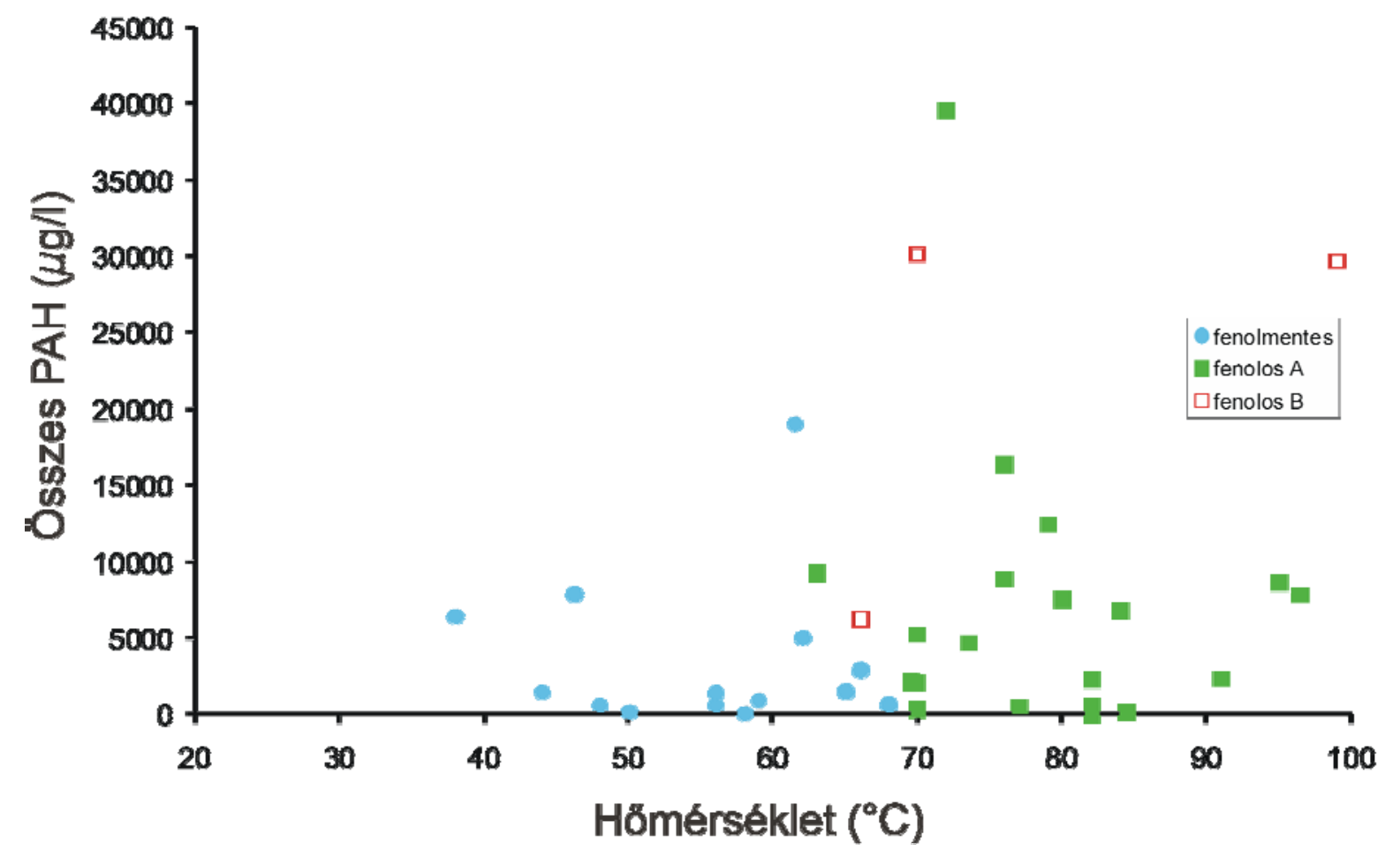

20. ábra. Az összes PAH koncentrációja $(\mu g / l)$.

A naftalin koncentrációja (21. ábra) és a naftalin aránya az összes PAH-hoz képest (22. ábra) kissé magasabb a fenolos vizekben. A kísérletekben és a szentes környéki hévizek egy részében (Sajgó et al., 2005) jó hőmérsékletmutatónak bizonyult fenantrén/antracén arány a hévizekben nem mutat hőmérsékletfüggést, sem különösebb eltérést a fenolos és fenolmentes vizekben (23. ábra).

A fenolokon belül a különféle alkilfenolok koncentrációi és ezek arányai sem hőmérsékletfüggők (11. táblázat). 


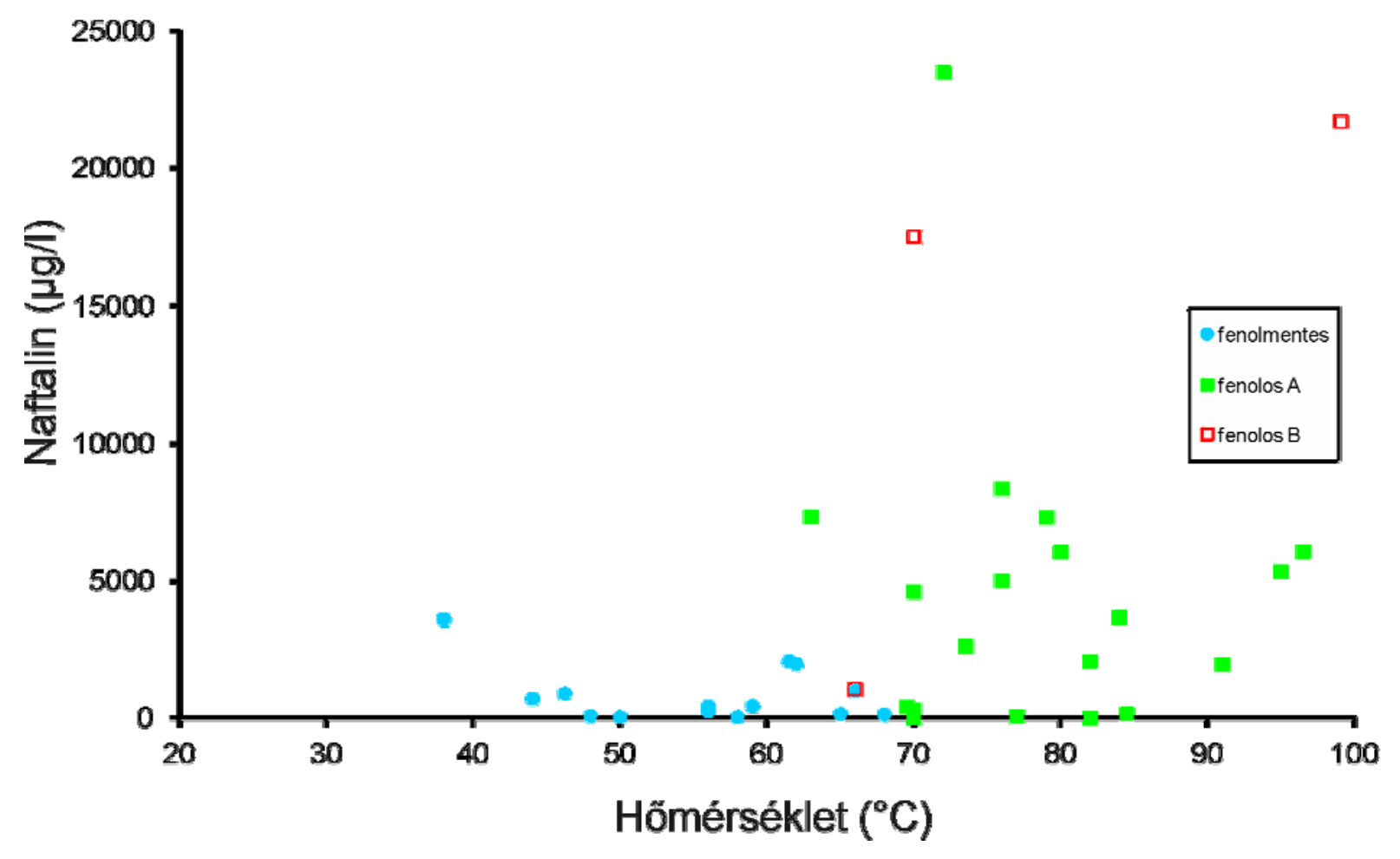

21. ábra. Naftalin koncentrációk ( $\mu \mathrm{g} / \mathrm{l})$

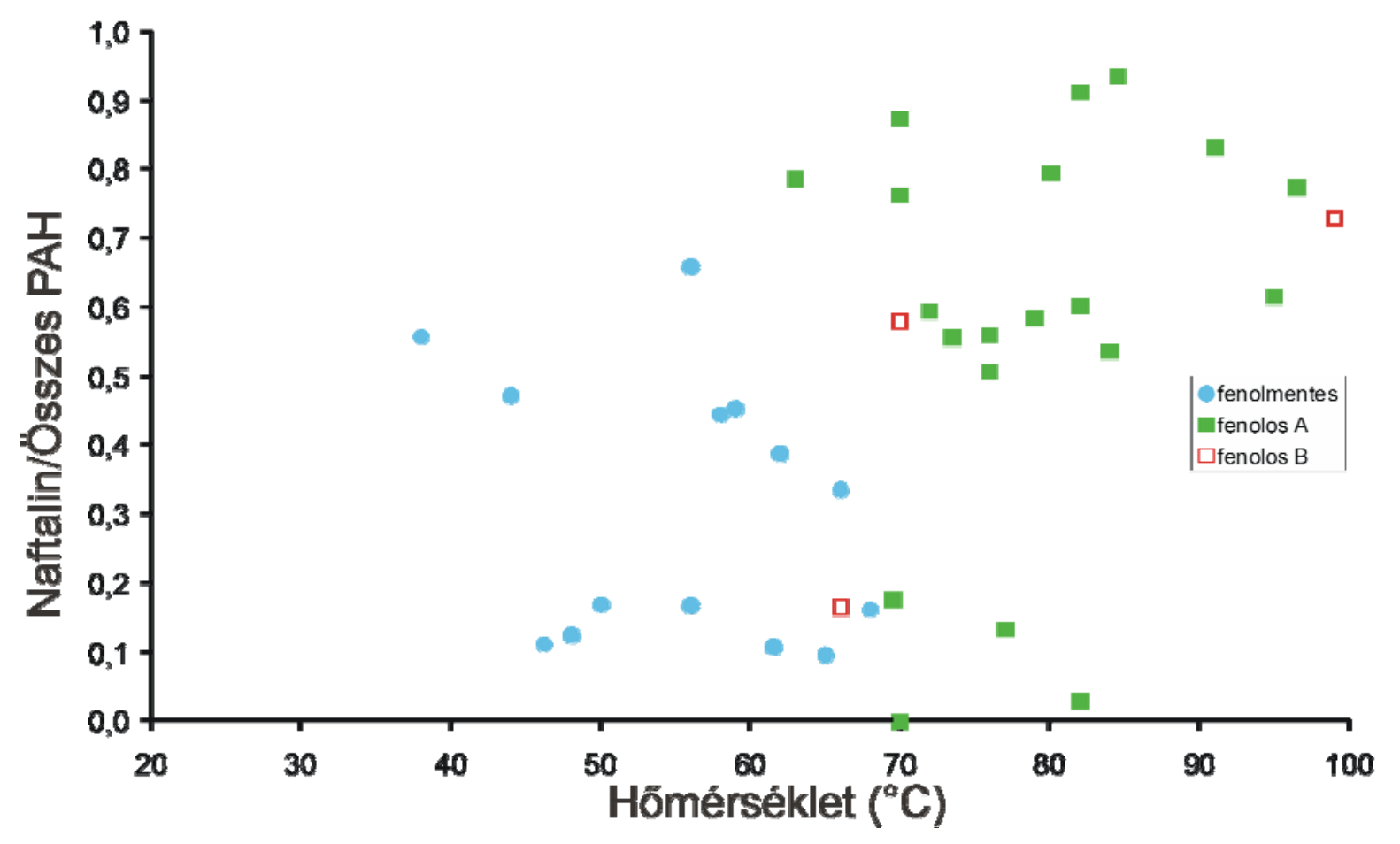

22. ábra. Naftalin/összes PAH a hömérséklet függvényében. 


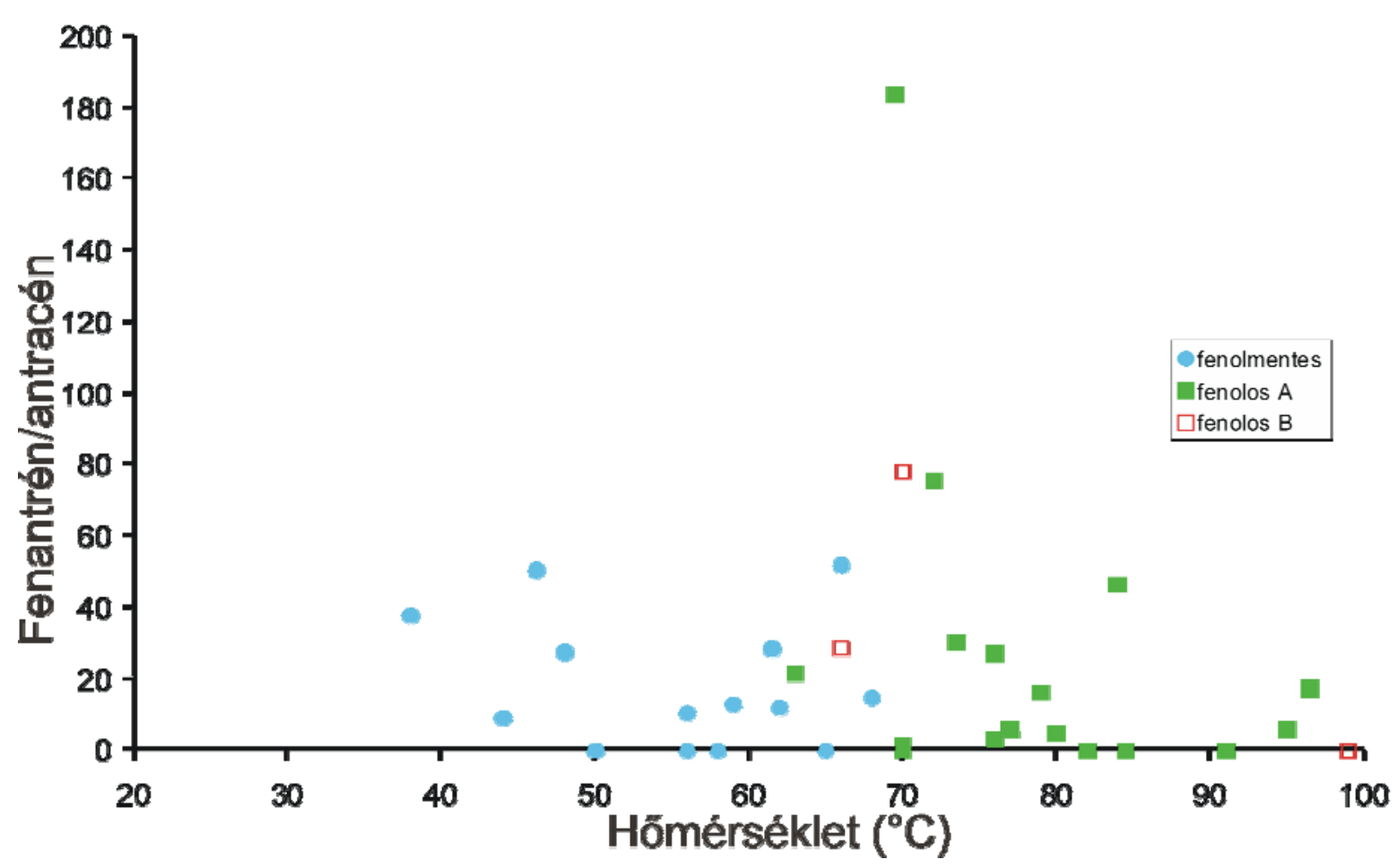

23. ábra. Fenantrén/antracén arány a hömérséklet függvényében.

Míg például Kárpáti (1999) egyértelmü összefüggést talált a hőmérséklet és a különféle oldott aromás vegyületek dominanciája között (növekvő hőmérséklettel: heteroaromás, alkilbenzol majd fenol az uralkodó vegyület), valamint egyértelmü (relatív) demetileződést figyelt meg az egyre melegebb vizekben, az értekezésemben vizsgált mintasoron ezek nem figyelhetők meg. Emellett a kísérleteim során bizonyos koncentrációk és mutatók egyértelmü hőmérsékletjelzőnek bizonyultak (pl. fenantrén/antracén hányados). Az eltérések okát az alábbi négy ténnyel magyarázom:

1) a kifolyó (sőt, akár a talp-) hőmérsékletek nem mindenképpen esnek egybe a víz által elért maximális hőmérséklettel, így nem szükséges lineáris összefüggésre számítanunk;

2) bár a kísérletekben különféle kiindulási szerves anyagokat hőkezeltem, nem volt lehetőségem vizsgálni a kőzetmátrix hatását, ami a természetben változatos lehet, és tartalmazhat erős katalizátor anyagokat (pl. agyagok), amik - ha nem is teljesen megváltoztatják, de - szelektíven felgyorsíthatják egyes folyamatok lejátszódását (pl. Katritzky et al., 2001);

3) amennyiben olyan, keverék vizeket is vizsgálunk, amik a szerves összetevők szempontjából eltérőek (tehát az egyéb tulajdonságaik nem feltétlenül különböznek), az egyik komponens eltérő (akár minimális vagy 0 ) oldott aromás tartalma 
4) Végül a jóval nagyobb mintaszámmal ( egy nagyságrenddel több minta) elvégzett korábbi vizsgálatokban a kiugró értékek kevésbé jelentkeztek, így az összefüggések megállapítása jóval inkább egyértelmü volt.

\subsection{A hévizekben és a kísérletekben mért szerves vegyületek összehasonlítása}

Az előző fejezetben megmutattam, hogy a kísérletek során megfigyelt trendekkel ellentétben a hévizekben a hőmérséklet és a szerves anyag bomlása között szoros kapcsolat nem áll fenn. Ennek okait részleteztem. Ebben a fejezetben a kísérletekben tett megfigyeléseket hasonlítom össze a vizsgált hévizekben mért szerves alkotók mennyiségével és arányaikkal.

Az összes alkilbenzol- és fenoltartalmat tekintve a vizekben hasonló koncentrációkat, illetve egy nagyságrendet nem meghaladó eltérést figyelhetünk meg, mint a kísérletekben. A minimum, maximum, átlag és medián értékeket a 16. táblázatban tüntettem fel. Látható, hogy a csak PAH koncentrációk térnek el jelentősen.

\begin{tabular}{|lcccc|}
\hline & & $\mathrm{ab}$ & PAH & Fenol \\
\hline hévizek & Max & 1900 & 39596 & 5991 \\
& Min & 0 & 21 & 0 \\
& Átlag & 267 & 6850 & 1118 \\
& Medián & 91 & 2934 & 39 \\
& Szórás & 450 & 9246 & 1765 \\
\hline kísérletek & Max & 578 & 354 & 1320 \\
& Min & 5 & 10 & 0 \\
& Átlag & 117 & 65 & 317 \\
& Medián & 77 & 48 & 240 \\
& Szórás & 135 & 70 & 313 \\
\hline
\end{tabular}

14. táblázat. Átlagos alkilbenzol, PAH és fenol koncentrációk $(\mu \mathrm{g} / \mathrm{l})$ a hévizekben és a kisérletekben.

A vegyületcsoportok arányait tekintve (24. ábra) két megfigyelés tehető: a fenolok aránya jóval nagyobb a kísérletekben, mint a hévizekben, míg a PAH-ok feltűnően dominánsak a hévizekben. A hévizekben az is látható, hogy az alkilbenzolok és a fenolok megjelenése küszöbhőmérsékletekhez (kb. $50^{\circ} \mathrm{C}$, illetve $70^{\circ} \mathrm{C}$, kifolyó) kötődik. 


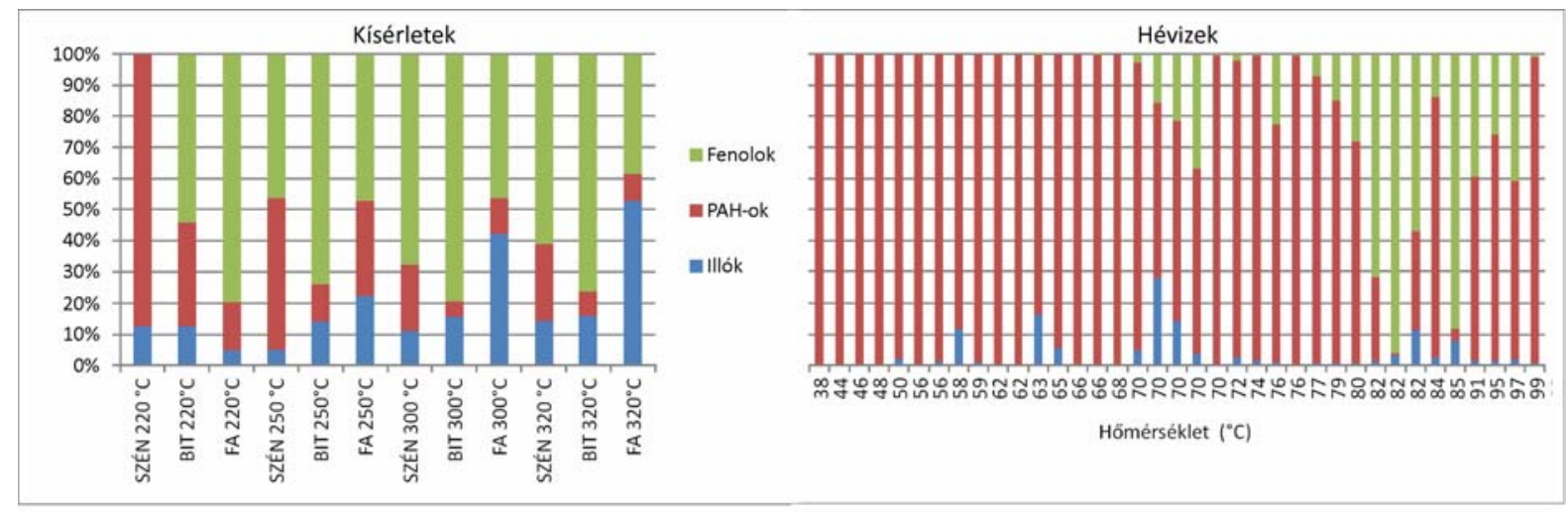

24. ábra. A kisérletek és a hévizek vegyületeinek aránya.

A PAH-ok tehát viszonylag hideg hévizekben is megjelennek, míg az alkilbenzolok, és főleg a fenolok hőmérsékleti határokhoz rendelhetők.

A vegyületeket vizsgálva megállapítható, hogy az érett hévizekben nagyobb mennyiségben található benzol és toluol, mint a kísérletek termékei között, míg a C2, C3, C4 komponensek mennyisége néhány kiugró hévíz adattól eltekintve hasonló. A PAH-ok mennyisége a gyürük számától függetlenül mindig nagyobb a hévizekben, mint a kísérletekben, ugyanez igaz a fenolok és alkilfenolok koncentrációira is. Nincs olyan vegyületcsoport a PAH-ok kivételével, ami arányaiban kiugróan eltérő lenne a két mintasorban. A benzol aránya az összes alkilbenzolhoz viszonyítva ( $\mathrm{b} / \mathrm{ab})$ a hévizekben általában nagyobb. Ha a toluolt a benzolhoz adjuk (bt/ab), a különbség még nagyobb. A teljes mintasort tekintve a mutatók nem függenek a hőmérséklettől, de a benzol és toluol kiugró aránya nem meglepő a relatív demetileződés folyamatos lejátszódása miatt.

A naftalin mennyisége jóval nagyobb a hévizekben, mint a kísérletekben, ugyanez igaz a legtöbb PAH-ra is. A f/a arány nem bizonyul hőmérsékletfüggő mutatónak, ellentétben a kísérletekben tapasztalttal.

A fentiekből következően elmondható az is, hogy a PAH-ok összmennyiségét az eltelt idő nagyobb mértékben befolyásolja, mint a hőmérséklet. Ezzel ellentétben a fenolok képződését elsősorban a hőmérséklet befolyásolja, az idő kevésbé. 


\section{4 Összegzés, következtetések}

A hévízmintákban a szerves anyag bomlása (érése) során keletkező aromás vegyületeket és a szerves anyag bomlás szervetlen összetételre gyakorolt hatását vizsgáltam ebben a fejezetben. A vizeket a fenol megjelenése alapján két csoportra bontva összehasonlítottam a csoportok szerves és szervetlen összetevőit. Az eredmények alapján az alábbi megállapításokat tettem: - a szerves anyag bomlása és a bomlástermékek minősége és összmennyisége a TOCtartalomtól és a kiindulási szerves anyag szárazföldi vagy tengeri eredetétől független, csak a víz hőmérséklete ( $\mathrm{a} \sim 70-80^{\circ} \mathrm{C}$ közötti küszöbhőmérséklet elérése) befolyásolja;

- az érés során első sorban fenol és benzol, illetve alkilbenzolok kerülnek a vízbe. PAH vegyületek közül a naftalin egy része is ebböl származik, a többi poliaromás szénhidrogén a hideg vizekben is jellemző vegyület;

- az érés során szén-dioxid is keletkezik, ami a szervetlen összetételt (nátrium, kálium és hidrogénkarbonát-tartalom) befolyásolja (emellett szénhidrogén gázok is keletkeznek Vető (2004a) alapján);

- az aromás vegyületek nem mutatnak lineáris összefüggést a hőmérséklettel, de a koncentrációk mellett a benzol és toluol aránya, illetve a naftalin aránya a PAH-okon belül eltér a fenolos és fenolmentes csoportban. Ennek többféle oka lehet: a vizek maximális hőmérséklete nem ismert, a vizek eredete és keveredése nem ismert, illetve az üledékek katalitikus hatása 


\section{A szerves anyag eredetének meghatározása}

A hévizekben talált szerves anyag eredetének meghatározása véleményem szerint akkor lehetséges, ha található olyan vegyület vagy vegyületcsoport, ami a kísérleti eredményekben és a természetben hasonlóan viselkedik. Ehhez az alábbi feltételeket kell elfogadni a folyamatról:

- a vegyületek keletkezése főleg a hőmérséklet és az idő által vezérelt folyamat;

- bizonyos vegyületek aránya egy adott rendszerre (hőmérséklet-idő) jellemző, amennyiben a kiindulási szerves anyag azonos;

- a hőmérséklet növelése bizonyos határokon belül a hosszabb idő hatását helyettesíti.

Amennyiben a hévizekben, ahol sokkal több körülmény változik (hőmérséklet, tartózkodási idő, litológia stb.), jó korrelációt látunk két paraméter koncentrációinak összefüggésében, elfogadhatjuk, hogy megfelel a fenti állításoknak, és a trend a prekurzor szerves anyagtól, esetleg az adott részmedence litológiájától függ.

Mivel a CSAP mintáról nem sok információ van, és részben mesterséges hatást mutat, a FA24 kísérletekben pedig a hőkezelés időtartamának hatását vizsgáltam, jelen fejezetben nem tárgyalom ezeket. Elsőre logikusnak tünne a FA és HA, mint lehetséges prekurzor anyag átlagos értékeit vizsgálni, mivel a természetben együtt jelennek meg. Azonban a kísérletek alapján a FA még élesen emelkedő alkilbenzol képződést mutat $320^{\circ} \mathrm{C}$-on is, míg a HA $300^{\circ} \mathrm{C}$ és $320^{\circ} \mathrm{C}$ között már stagnál, illetve inkább kissé csökken. Emellett megállapítható, hogy a fulvosavak bomlása intenzívebb, mint a huminsavaké (pl. Kovács, 2010). Tehát a FA hatása arányaiban minden bizonnyal felülírja a HA hatását. A HAFA kísérleti anyag egy vízben oldott, érett humin anyag, ami sokkal inkább a vizsgált aromás keletkezési folyamatok egyik (érési) terméke, mint azok prekurzor anyaga. Ezért az eredetvizsgálat szempontjából, ami egyfajta mesterséges érlelést jelent, nem releváns az összehasonlítás során.

A hévizekben nincs olyan mutató (ellentétben a kísérletek eredményeivel, pl. fenantrén/antracén), ami szoros korrelációt mutatna a kifolyási hőmérséklettel. Kifejtettem, hogy nem csak a kifolyási és talphömérséklet közötti különbség bizonytalansága okozza ezt a jelenséget, hanem az is, hogy a víz által elért maximális hőmérsékletről nincsen információnk. Ráadásul a különféle részmedencék, ahonnan a vizek származnak, eltérő arányban tartalmazhatják az oldott szerves alkotók prekurzor szerves anyagait és a katalitikus hatású üledékek aránya is eltérhet. 
Mivel a benzol aránya az alkilbenzolokhoz viszonyítva jelentős eltéréseket mutat a kiindulási anyag és a kezelési hőmérsékletek függvényében (2. fejezet), megvizsgáltam azt, hogy a b/ab mutató alkalmas-e a prekurzor anyag meghatározására. A vizes pirolízis kísérletekből kiderül, hogy az alkilbenzolok koncentrációját a folyamatos keletkezésük növeli és polikondenzációjuk csökkenti (2. fejezet), valamint a demetileződés befolyásolja. Ezért adott körülmények között elfogadható, hogy arányuk jellemző egy adott rendszerre, még akkor is, ha geológiai időskálán (mint a hévizekben) a folyamat ( $\mathrm{pl}$,. demetileződés) iránya nem egyértelmü, mivel a lejátszódó reakciók dominanciája változhat.

Két részmedencéből áll rendelkezésre több minta (Békési-medence: 7db, illetve MakóHódmezővásárhelyi-árok: 15db), ahol lehetőség van ezt a hipotézist ellenőrizni. Ezzel együtt a kisebb mintaszámmal rendelkező területeket is megvizsgálom (Pusztaföldvári-hát: 4db, Hajdúszoboszló környéke: $3 \mathrm{db}$, és a Jászság területe: $3 \mathrm{db}$ ).

A 25. ábrán látható a különböző medencékből származó hévizek benzoltartalma az összes alkilbenzol koncentráció függvényében.

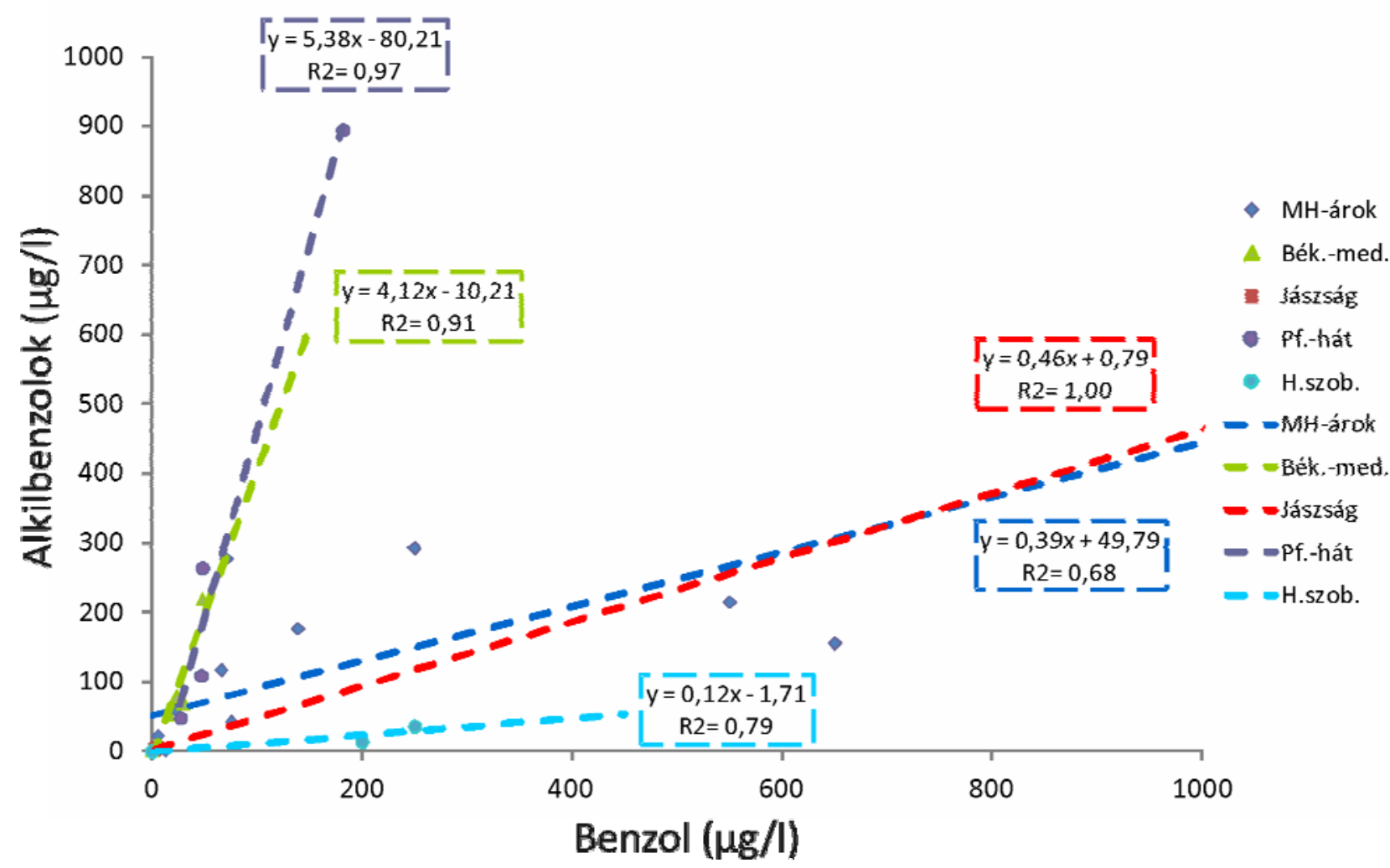

25. ábra. A benzol koncentráció és az összes alkilbenzol-tartalom összefüggése és trendje az eltérö területekről származó hévizekben. 
Megfigyelhető, hogy a trendvonal kiváló lineáris korrelációt mutat, és a Pusztaföldvári-hát Békési-medence, illetve a Jászság - Makó-Hódmezővásárhelyi-árok trendje majdnem párhuzamos, míg a Hajdúszoboszló környéki mintáké eltérő. Ha a fejezet elején megfogalmazott állításokat figyelembe vesszük, és azt, hogy emellett a b/a arány gyakorlatilag 0 és 1 között ingadozik, a 0,68 és nagyobb $\mathrm{R}^{2}$ értékek azt mutatják, hogy a szerves anyag érés során keletkező benzol és alkilbenzolok koncentrációinak nagyon szoros lineáris korrelációja nem véletlen. Olyan folyamatról van szó, amire érvényes mindhárom említett állítás, és a kijelölt trendek csak a medencénként eltérő paraméterektől (litológia, kiindulási szerves anyag minősége, mennyisége) függenek.

Ha hasonló módon ábrázoljuk a kísérletekből kapott eredményeket a lehetséges prekurzor anyagokra, szintén jó lineáris korrelációs trendeket figyelhetünk meg (26. ábra). Ebben az esetben a FA, SZÉN és BIT értékeit tüntettem fel, a fentebb már sorolt okok miatt.

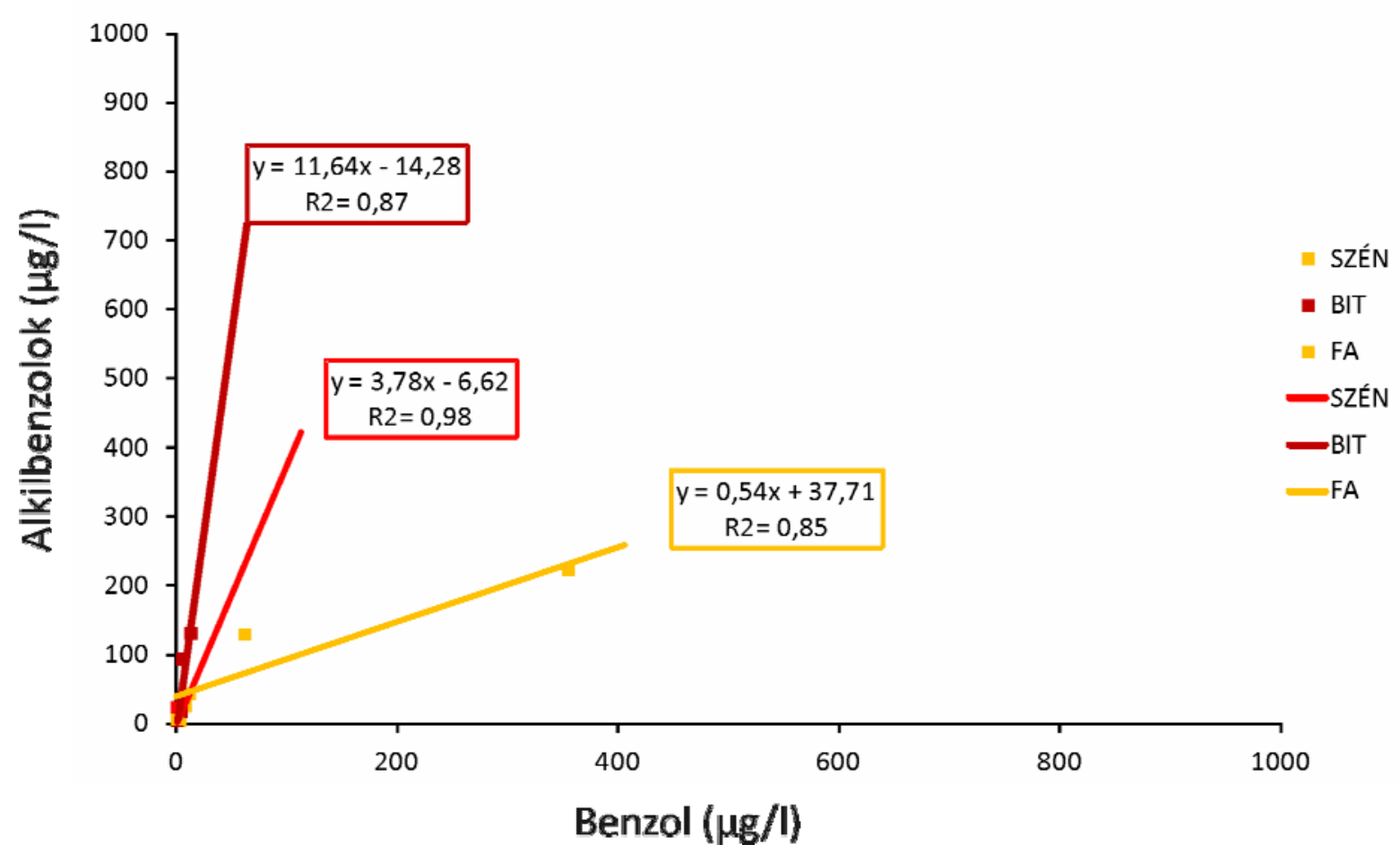

26. ábra. A benzol koncentráció és az összes alkilbenzol-tartalom összefüggése és trendje különféle hökezelt mintákban.

Itt is külön hangsúlyozandó, hogy a legrosszabb $\mathrm{R}^{2}$ értéke 0,85 , ami még mindig nagyon erős összefüggést mutat. Ebben az esetben a FA trendje erősen különbözik a SZÉN és BIT trendjétől, amelyek tengelymetszete azonos, meredekségük azonban eltér. Ezek az egyenesek tehát az adott kísérleti anyagra jellemző benzol - összes alkilbenzol érési trendek. 
Ha a két ábrát összevetjük, meglepő jelenség látható: az érési trendek párhuzamosak vagy közel egybeesnek a kísérletekben és a hévizekben (27. ábra).

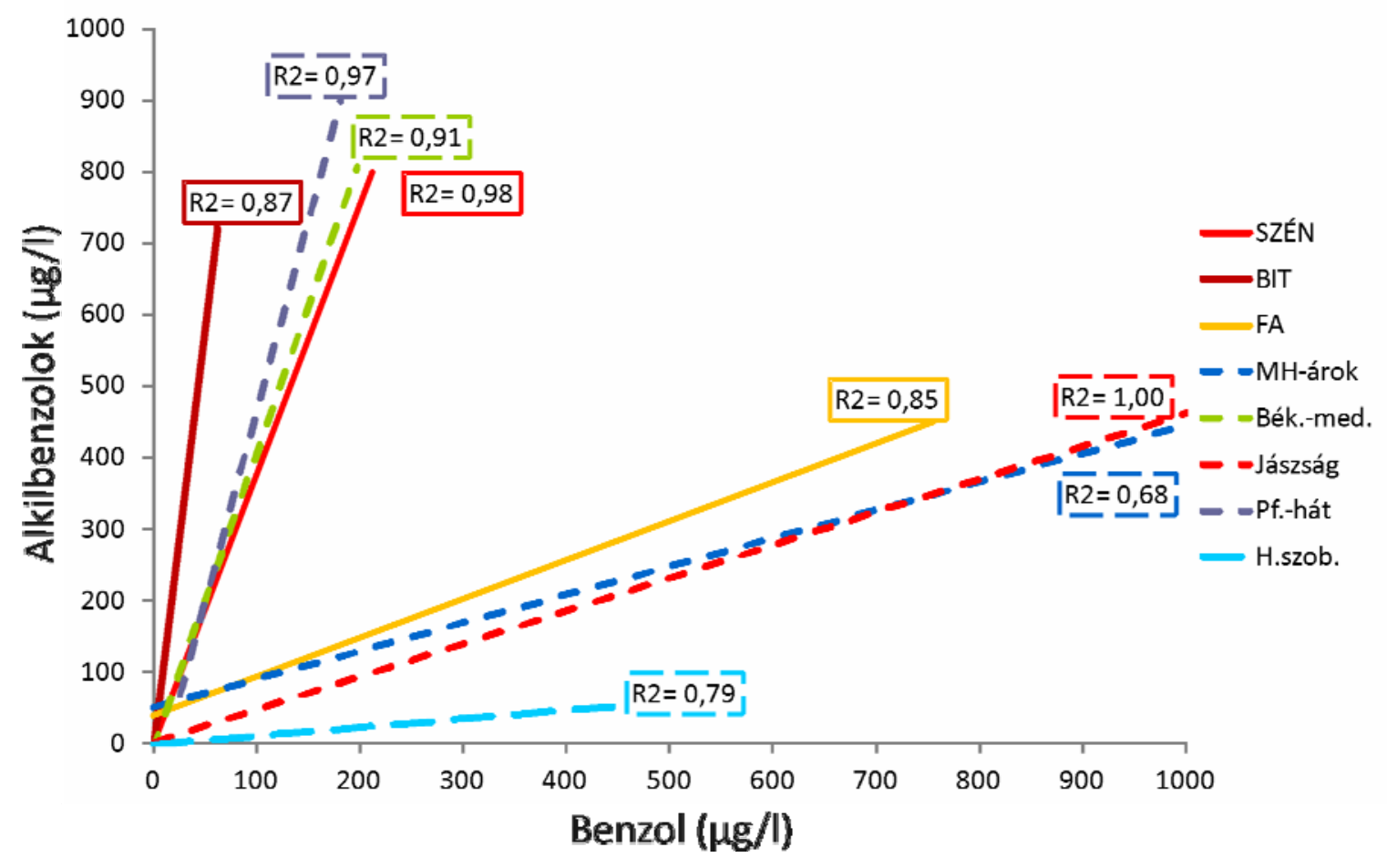

27. ábra. A hévizekben és a kísérletek során megfigyelt trendek összevetése.

Az öt területből négy két, élesen elváló csoportba osztható, és ezek trendvonalai annyira közel esnek a kétféle prekurzor anyagcsoportéhoz, hogy elfogadható az a feltételezés, mely szerint a Békési-medencéböl és a Pusztaföldvári-hátról származó hévizek föleg lignit és/vagy bitumen bomlásából keletkeztek, míg a Jászságból és a Makó-Hódmezővásárhelyi-árokból származók inkább föleg humin anyagokból, azon belül is a huminsavtól jóval intenzívebben bomló fulvosavból származnak. A Hajdúszoboszlói minták ezektől eltérőek.

Természetesen a litológia hatását jelenlegi ismereteink alapján nem tudjuk meghatározni, de mint azt korábban már említettem, - például az agyagok katalitikus hatása inkább felgyorsíthat, mint alapvetően megváltoztathat bizonyos folyamatokat. Értelemszerűen a további kutatások, például az elemzés a Kárpáti (1999) által vizsgált mintákra való kiterjesztése megerősítheti vagy cáfolhatja jelen elméletet. 


\section{6. Összegzés és következtetések}

Értekezésemben a Pannon-medence hévizeiben található oldott szerves anyag viselkedését (bomlás, keletkező aromás vegyületek minősége, mennyisége) és eredetét vizsgáltam. Az oldott szerves anyagok egy része mérgező és/vagy rákkeltő, illetve egészségre pozitív hatású is lehet, így vizsgálatuk balneológiai és ivóvíz-használati szempontból egyaránt lényeges. Mivel a szerves molekulák mérete változik az oldat fizikai és kémiai tulajdonságaitól függően, a geotermikus felhasználás érdekében is fontos viselkedésük megismerése. Kutatásom során célom volt bemutatni, hogy a vizsgált hévizekben a szerves anyag bomlása, ami a korábbi vizsgálatok (Vető et al., 2004b; Fekete et al., 2009; 2010b) alapján jelentősen befolyásolja a vizek szervetlen kémiai összetételét (hidrogén-karbonát, nátriumtartalom), egyben forrása az oldott aromás szerves vegyületeknek. Ezek a vegyületek egy adott küszöbhőmérséklet felett jelennek meg, és koncentrációjuk nem függ a mért oldott szervesanyag-tartalom nagyságától (TOC), sem a kiindulási szerves anyag vagy termálvíz eredetétől (szárazföldi - tengeri).

Kísérleti körülmények között modelleztem a vízben oldódó aromás szerves vegyületek keletkezését és megvizsgáltam, hogy a különféle szerves anyagokból (humin- és fulvosavak, bitumen, lignit és geotermális felhasználás során vízből kivált szerves anyag) jellemzően milyen kromatografálható aromás vegyületek keletkeznek vizes közegben történő hőkezelés hatására. Végül a kísérletekben vizsgált szerves anyagokból keletkezett vegyületek minősége és mennyisége, valamint ezek arányai alapján igyekeztem meghatározni (inkább valószínüsíteni) a vizsgált hévizek oldott szerves anyagainak eredetét, azaz a keletkezésükért felelős prekurzor szerves anyag típusát.

A szerves anyag vizes közegben történő termikus változásának/érésének tanulmányozása érdekében aquatermolízis kísérleteket terveztem meg és végeztem el különféle, feltételezett prekurzor szerves anyagokon. A kromatografálható aromás vegyületekről kapott eredményeket összehasonlítottam a hévizekben mért aromás szerves alkotókról kapott mennyiségi és minőségi elemzésekkel, és ezek alapján új módszert találtam az egy adott medencéből származó hévizek oldott szerves anyagainak domináns prekurzor anyag típusának meghatározására.

A kutatás alapján az alábbi megállapításokat tettem az oldott szerves anyagokról a hévizekben és a kapcsolódó aqutermolízis kísérletekben: 
Megerősítettem azt a megállapítást (pl. Varsányi, 1994 és Vető et al., 1998), hogy a szerves anyag bomlása alapvetően befolyásolja a Pannon-medence hévizeinek szervetlen vízkémiai összetételét. A szerves anyag bomlása széndioxidot, szénhidrogén gázokat és vízben oldódó aromás vegyületeket (alkilbenzolok, PAH-ok, fenolok és heteroaromás vegyületek) termel. A széndioxid-termelés hatására nő a hidrogén-karbonát és a nátrium (valamint a kálium) koncentrációja, aminek az oka a karbonátok fokozott oldódása és a földpátok hidrolízise.

A Pannon-medence hévizeiben a szerves anyag többféle eredetü lehet. A pozitívabb $\delta^{18} \mathrm{O}$ értékkel és nagyobb kloridtartalommal jellemezhető vizek szerves anyaga a jodidion-tartalom alapján tengeri eredetü, míg a fiatalabbaké inkább tavi vagy szárazföldi A szerves anyag érésével bekövetkező aromás vegyületek képződését azonban ez a különbség nem befolyásolja.

Megállapítottam, hogy a hévizekben talált oldott alkilbenzolok, policiklikus aromás szénhidrogének (PAH) és fenolok megjelenése nem kötődik kőolajtelepekhez. Sokféle éretlen (humin anyagok) vagy akár érettebb (lignit) szerves anyag képes ilyen aromás vegyületeket termelni, különböző eloszlásban és mennyiségben.

Megállapítottam, hogy a természetes vizekben megtalálható fenolok képződéséhez és az alkilbenzolok nagy mennyiségben való megjelenéséhez adott hőmérsékleti küszöb elérése szükséges. A PAH-ok hideg hévizekben is megjelennek, a nagyobb molekulájú szerves vegyületek részleges oldódása következtében. A hőmérsékleten kívül egyéb tényező (pl. TOC-tartalom) nem befolyásolja a fenolok (és az ezekkel összefüggésben megjelenő alkilbenzolok) keletkezését. PAH-ok közül a naftalin egy része bizonyosan a termikus bomlás terméke.

Vizes hőkezeléses kísérletekkel (aquatermolízis) bemutattam, hogy a vízben oldott szerves anyagok termikus változása, illetve érése jól modellezhető. Ezen belül a módszer főleg az alkilbenzolok és fenolok esetében alkalmazható kiválóan, de a PAH-ok és heteroaromás vegyületek esetében is alkalmas a vegyületek viselkedésének leírására.

A vizes közegben végzett hőkezeléses kísérletekkel (aquatermolízis) megerősítettem a vízben oldott szerves anyag érésekor feltételezett meghatározó folyamatok lejátszódását: 
- C-C és C-heteroatom kötések felbomlásával a makromolekulák alkilbenzolokká és PAH-okká bomlanak,

- az alkilbenzolok policiklizáción és aromatizáción mennek keresztül,

- a heteroaromás vegyületek a kötések felszakadásával és heteroatom-vesztéssel alkilbenzolokat termelnek,

- az aromás vegyületek alkilláncai relatív láncrövidülést (demetileződést) mutatnak.

Az benzol és az alkilbenzolok arányáról megállapítottam, hogy az elsősorban a kiindulási szerves anyag minőségétől függ, és az érés előrehaladásával lineáris összefüggést mutat egyegy szervesanyag-típus esetében. Ez alapján lehetséges megállapítani a Pannon-medence egyes részmedencéiben, illetve területein a szerves anyag eredetét, azaz a legnagyobb arányban jelen levő prekurzor szerves anyagot.

Véleményem szerint a Békési-medencéből és a Pusztaföldvári-hátról származó hévizek főleg szén és/vagy bitumen bomlásából keletkeztek, míg a Jászságból és a MakóHódmezővásárhelyi-árokból származók főleg humin anyagokból, azon belül is leginkább fulvosavból származnak. Természetesen ezt a megállapítást a mintaszám növelésével szükséges megvizsgálni. 


\section{Summary}

Thermal waters in the Pannonian Basin may contain high amounts of dissolved organic matter that may exert positive and negative effects on their use. Thermal waters are used for balneologic purposes and organic compounds may contribute to the curative power. In Hungary thermal waters are mixed to drinking water (mostly in those areas where natural arsenic content is increased in groundwater). In case of geothermal use, the coagulating organic matter greatly decreases the efficiency of re-injecting wells (by two orders of magnitude) causing an additional cost. However, according to the legal regulations the detailed analysis of organic compounds is not obligatory. For these reasons research on origin and behaviour of organic compounds in thermal waters has a great importance.

During the last two decades mono- and polyaromatic compounds were found at hundreds of water localities studied. Among these were benzene and alkylbenzene homologues, polycyclic aromatic hydrocarbons (PAH), phenol homologues, mono- and polycyclic heteroaromatic compounds. Some of these are toxic and/or carcinogen (e. g. benzene, phenols, PAH-s), or act as precursors of chlorinated hydrocarbons.

The aims of my research was to study the decomposition of organic matter as the source of these aromatic compounds, the temperature dependency of the concentrations and qualities of the aromatic products and their relationship with the origin of the water.

I also carried out hydrous pyrolysis (aquathermolysis) experiments on different precursor candidates (humic and fulvic acid, bitumen, lignite and a precipitate from a geothermal well) to model the generation of aromatic compounds in water. I compared the results of the experiments with the observations on thermal waters to describe the effect of temperature and precursor material and thus, assess the type of the major contributing organic matter.

On the basis of the literature, description of the reactions by exact chemical equations is not possible because of the very complex chemical structures and the presence of several simultaneous and competitive chemical reactions; however, it is possible to examine the temperature dependent trends.

Aquathermolysis experiments were carried out in stainless steel vessels under oxidative and reductive conditions. The experimental temperatures were generally as follows: $220^{\circ} \mathrm{C}$, $250^{\circ} \mathrm{C}, 300^{\circ} \mathrm{C}, 320^{\circ} \mathrm{C}$ with treatment time of 72 hours. The fulvic acid sample was also treated for 24 hours at the same temperatures to study the effect of the duration of thermal treatment. Generated products (benzene and alkylbenzene homologues, PAHs, heteroaromatic 
and phenol homologues) were measured by gas chromatography/mass spectrometry (GC/MS). The results show that the reactions (generation and decomposition of various sized molecules) run simultaneously. The temperature and the duration of the treatment influence the relative intensities of the different competitive reactions. Particular reactions become more dominant with increasing temperature and/or longer treatment time.

On the basis of the experiments I showed the occurrence of the following reactions:

- decomposition of large precursor molecules to smaller ones and to aromatic hydrocarbons through break-up of C-C or C-heteroatom bonds and decomposition of heteroaromatic rings;

- relative demethylation with increasing temperature and time;

- polycondensation and aromatisation.

The compounds generated in the experiments are more or less similar, but concentrations and proportions differ depending on the precursor material which reflects differences in chemical structure and composition.

On the basis of the results I suggest that hydrous pyrolysis experiments carried out under reductive conditions are adequate to model thermal maturation of organic matter in thermal waters. The $\sim 70-80^{\circ} \mathrm{C}$ threshold temperature of alkylbenzene generation observed in thermal waters in the Pannonian Basin is about equivalent to $220^{\circ} \mathrm{C}$ in the 72 hours termed experiments. The successive appearance of the compound homologues (heteroaromatics, alkylbenzenes and phenols with increasing temperature) can be observed in thermal waters and experiments equally.

The effect of organic matter decomposition ( maturation) on water composition was also studied on almost 40 thermal waters. Samples were separated into two groups on the basis of the presence (or absence) of phenols and various organic and inorganic chemical characteristics were measured and described. The results can be summarized as follows:

- During thermal maturation the major aromatic products are phenols. Benzene, alkylbenzenes and naphthalene are also generated. Naphthalene and other PAHs are abundant in lukewarm waters as well.

- Decomposition of organic matter and the quality and concentrations of the products are independent of TOC content and of the origin of thermal water, but the appearance of decomposition products is bound to a threshold (outflow) temperature of $\sim 50^{\circ} \mathrm{C}$ and $\sim 70^{\circ} \mathrm{C}$ in case of alkylbenzenes and phenols, respectively. 
- Maturation generates carbon dioxide, which reacts with rock matrix to produce inorganic components (increasing sodium, potassium and bicarbonate concentrations) and hydrocarbon gases are also produced.

- Concentrations do not show linear temperature dependence, however, concentrations, benzene to alkylbenzene ratios and the proportion of naphthalene among PAHs are different between the phenolic and non-phenolic waters. These phenomena may be due to unknown maximum water temperatures and water mixing proportions, and to the uncertainties in catalytic effects of sediments, like clay minerals.

Comparing the results of the experiments with those of thermal water studies, we can observe that total alkylbenzene and phenol concentrations are in the similar range, while PAH concentrations are higher in thermal waters than in the experiments. Considering the ratios of different homologue series, the proportion of phenols is much higher in the experiments than in the waters, and PAHs are unequivocally dominant in thermal waters. It is notable that the appearances of alkylbenzenes and phenols are bound to threshold temperatures $\left(50^{\circ} \mathrm{C}\right.$ and $70^{\circ} \mathrm{C}$, respectively) in thermal waters. PAHs are present in lukewarm waters as well, as stated before. Thermal waters contain relatively more benzene and toluene than experimental samples.

The lack of linear correlation between temperature and concentration values of any compound in the case of thermal waters is not easy to evaluate on the basis of former studies (e. g. Kárpáti, 1999) and experimental data, which suggested strongly temperature dependent ratios. I propose the following possible explanations:

- The outflow or bottom hole temperatures do not necessarily reflect the maximum temperature reached by a given thermal water.

- The effect of rock matrix was not tested during the experiments. Various sediments occur in the studied subbasins, thus the presence of strong catalysts (like clay minerals) can not be excluded, which may not change, but selectively accelerate particular reactions.

- Water mixing proportions and end-members are not known in these hydrogeological systems, which may complicate the data interpretation.

On the basis of these data it was not possible to assign any marker compound specific for a given precursor, but the origin of organic matter in thermal waters may be determined by the use of aromatic compound ratios. 
The comparison of benzene to alkylbenzene concentrations shows excellent linear correlations in thermal waters originating from different sub-basins. The five different subbasins are separated into two groups on the basis of the trend lines.

Also, linear trends can be observed for the increasing heating temperatures (thermal maturation) in the results of experiments, where the possible precursors determine the slope of the trend line. In this case two groups are formed, which fall very close to the thermal water groups. We can assume that the major precursor of the organic matter of the thermal waters in a given sub-basin is the one that is characterized by similar maturation trend to that observed in the sub-basin. 


\section{Köszönetnyilvánítás}

Ezúton szeretnék köszönetet mondani mindazoknak, akik nélkül ez a kutatás nem valósulhatott volna meg, illetve azoknak, akik a szakmai munkán kívül is mindvégig támogattak. Próbálom ezt a teljesség igényével megtenni, de természetesen tisztában vagyok azzal, hogy ez nem lehetséges. Elöljáróban is bocsánatát kérem azoknak, akik jelen felsorolásból jogtalanul kimaradnak, remélem, hogy ha írásban nem, de szavakkal kifejezhetem hálámat feléjük.

Elsősorban köszönet illeti Kárpáti Zoltánt, aki a hévizek szerves anyagainak hazai kutatását megalapozta, rendelkezésemre bocsátotta az adatokat és számtalan jó tanácsot adott. Horváth István, aki sajnos már nincs köztünk, felbecsülhetetlen segítséget nyújtott a szervetlen vízkémiai eredmények megértésében és feldolgozásában.

Munkahelyi témavezetőm, Sajgó Csanád vezetett be a szerves geokémia tudományába, és minden kisebb-nagyobb probléma esetén fordulhattam hozzá, nem csak a doktori kutatásomhoz kapcsolódó kísérletek tervezése és az eredmények értelmezése során, hanem az időközben elvégzett számos egyéb vizsgálat esetében is.

Köszönet illeti témavezetőmet, Hetényi Magdolna akadémikust, aki lehetővé tette, hogy ezt a kutatást a Szegedi Tudományegyetem Környezettudományi Doktori Iskolája keretében végezzem, és sokszor volt segítségemre a doktori iskolával kapcsolatos számtalan szakmai és ügyintézéshez kapcsolódó kérdésben.

A kutatás nem készülhetett volna el az EKOL laboratórium vezetőjének (Eke Zsuzsanna) engedélye és tanácsai, valamint a kísérleti eredmények mérését végző Kramarics Áron jelentős közremüködése nélkül.

Hálával tartozom egykori igazgatómnak, Árkai Péter akadémikusnak, aki alkalmazásommal bizalmát fejezte ki irányomban, és jelenlegi igazgatómnak, Demény Attila akadémikusnak, aki a - geológusoktól többnyire idegen - témámmal való ismerkedésem kezdeti publikációs és kutatásbeli akadozását türelemmel viselte, és mindenben támogatott.

Köszönöm Vető István és Varsányi Zoltánné sok hasznos tanácsát, ötletét és javaslatát, sokat tanultam belölük.

Kisebb, de fontos részt vállalt a kísérleti munkából Bánkiné Mészáros Eleonóra kollégám, segítségét ezúton is köszönöm. A kísérletek gyakorlati kivitelezésében való segítségért köszönetet mondok Gede Lászlónak és Árokszállási Gábornak. 
A minták egy részének elökészítéséért, többszöri, hasznos szakmai beszélgetésért mondok köszönetet Kovács Krisztinának, és a liofilizálásért Mohr Anitának.

Uhrin Andrástól és kollégáimtól, Kele Sándortól, Czuppon Györgytöl és Barna Gabriellától sok jó tanácsot kaptam, köszönöm nekik is a segítséget.

Természetesen rendkívül hálás vagyok feleségemnek és családom többi tagjának is, akik általában jól viselték, hogy nem vagyok ott, vagy nem oda figyelek. Köszönöm barátaimnak, hogy mindig érdeklődtek a dolgozatomról, és legtöbbször a választ is végighallgatták. 


\section{Irodalomjegyzék}

Badics, B., Uhrin, A., Vető, I., Bartha, A., Sajgó, Cs. (2011)Medenceközponti földgázelőfordulás elemzése a Makói-árokban. Földtani Közlöny 141, 23-40.

Barbier, J., Charon, N., Dupassieux, N., Loppinet-Serani, A., Mahé, L., Ponthus, J., Courtiade, M., Ducrozet, A., Quoineaud, A-A., Cansell, F. (2012) Hydrothermal conversion of lignin compounds. A detailed study of fragmentation and condensation reaction pathways. Biomass and Bioenergy, in press, http://dx.doi.org/10.1016/j.biombioe.2012.07.011

Behar, F., Lewan, M. D., Lorant, F., Vandenbroucke, M. (2003) Comparison of artificial maturation of lignite in hydrous and nonhydrous conditions. Organic Geochemistry $34,575-600$.

Carothers, W. W., Kharaka, Y. K. (1978) Aliphatic acids in oil field waters - implications for origin of natural gas. AAPG Bulletin 62, 2441-2453.

Clayton, J.L., Spencer, C.W., Koncz, I., Szalay, Á (1990) Origin and migration of hydrocarbon gases and carbon dioxide, Békés Basin, southeastern Hungary. Organic Geochemistry 15, 233-247.

Collins, A. G. (1975) Geochemistry of Oilfield Waters. New York. Elsevier Scientific Publishing Company. 496 p.

Curtis, C. D. (1978). Possible links between sandstone diagenesis and depth-related geochemical reactions occurring in enclosing mudstones. Geological Society of London Journal, 135, 107-117.

Csizmeg J., Gy. Juhász, K Milota, Gy. Pogácsás (2011) Subsidence, Thermal and Maturity History of Late Miocene to Quaternary Formations in the Pannonian Basin., AAPG ICE, Milano, Extended Abstract, Search and Discovery 1072033.

Deák J. (1995) A felszín alatti vizek utánpótlódásának meghatározása izotópos módszerekkel az Alföldön. VITUKI Zárójelentés, pp. 28.

Degens, E. T., Hunt, J. M., Reuter, J. H., Reed, W. E. (1964) Data on the distribution of amino acids and oxygen isotopes in petroleum brine waters of various geologic ages. Sedimentology 3, 199-225. 
Di Gioia, M.L., Leggio, A., Le Pera, A., Liguori, A., Perri, F., (2006) Occurrence of organic compounds in the thermal sulphurous waters of Calabria, Italy. Chromatographia $63,585-590$.

Drummond, S. E:, Palmer, D. A. (1985) Formation constants for aqueous ferrous acetate complexes from magnetite solubility measurements from $100^{\circ} \mathrm{C}$ to $250^{\circ} \mathrm{C}$ and 250 to 1250 bars. Geological Society of America, Abstracts with Programs 17, 567.

Drummond, S.E., Palmer, D. A. (1986) Thermal decarboxylation of acetate. Part II. Boundary conditions for the role of acetate in the primary migration of natural gas and the transportation of metals in hydrothermal systems. Geochimica et Cosmochimica Acta 50, 825-833

Eisma, E., Jurg, J. W. (1967) Fundamental aspects of the diagenesis of organic matter and the formation of hydrocarbons: Proceedings, Seventh World Petroleum Congress, v. 2, p. 61-72.

Fekete J., Kovács K., Sajgó Cs., Tombácz E., Brukner-Wein A., Kárpáti Z., Gáspár A., Philippe, Schmitt-Kopplin (2008) Humin- és fulvosavak vizsgálata DK-Alföldi hévizeinkben. In: Földtudományok az emberiségért a Kárpát-medencében. Program, előadáskivonatok, HUNGEO 2008, Eötvös Workshop, Budapest (Szerk. Kovács-Pállfy P és mtsai) F12, 79.

Fekete J., Sajgó Cs., Horváth I., Kárpáti Z., Vető I., Hetényi M. (2009) Interaction and variation of isotopic age, temperature, organic and inorganic solutes in Hungarian thermal waters. Central European Geology, 52, 269-285.

Fekete J., Sajgó Cs., Horváth I., Kárpáti Z. (2010a) Hévizeink szerves és szervetlen fáciese. In: Medencefejlődés és geológiai erőforrások: Víz, szénhidrogén, geotermikus energia (ed: Pál-Molnár E.) GeoLitera, Szeged., 2010., 56-58.

Fekete J., Sajgó Cs., Horváth I., Kárpáti Z. (2010b) Összefüggés hazai hévizeink izotópos kora, hőmérséklete, szerves és szervetlen fáciesei között. Hidrológiai Közlöny 90, $53-58$.

Fekete J., Sajgó Cs., Kramarics Á., Eke Zs., Kárpáti Z. (2011) Simulation of organic matter maturation in thermal waters by model experiments. $25^{\text {th }}$ International Meeting on Organic Geochemistry, 18-23. September 2011, Interlaken, Switzerland. Book of Abstracts (IMOG 2011 Secretary, Rapiergroup, Middlesex, UK), P-235., 371. 
Fekete J., Sajgó Cs., Kramarics Á., Eke Zs., Kovács K., Kárpáti Z. (2012) Aquathermolysis of humic and fulvic acids: Simulation of organic matter maturation in hot thermal waters. Organic Geochemistry 53, 109-118.

Fuge, R., Johnson, C. (1986) The geochemistry of iodine - a review. Environmental Geochemistry and Health, 8/2, 31-35.

Gábris Gy., Nádor A. (2007) Long-term fluvial archives in Hungary: response of the Danube and Tisza rivers to tectonic movements and climatic changes during the Quaternary: a review and new synthesis. Quaternary Science Reviews 26, 27582782 .

González-Barreiro, C., Cancho-Grande, B., Araujo-Nespereira, P., Cid-Fernández, j. A., Simal-Gándara, J. (2009) Occurrence of soluble organic compounds in thermal waters by ion trap mass detection. Chemosphere 75, 34-47.

Haas, J. L. Jr. (1978) An empirical equation with tables of smoothed solubilities of methane in water and aqueous sodium cloride solutions up to 25 weight percent, $360^{\circ} \mathrm{C}$, and 138 MPa. U.S.Geological Survey Open-File Report 78-1004, 41 p.

Hem, J. D. (1985) Study and Interpretation of the Chemical Characteristics of Natural Water. USGS Water-Supply Paper 2254.

Hoering, T.C., (1984) Thermal reactions of kerogen with added water, heavy water and pure organic substances. Organic Geochemistry 5, 267-278.

Jencsel, H., Boda, E., Szamosfalvi, Á. (2007) Új összefüggés a kifolyóvíz és a réteghőmérséklet között. Ifjú Szakemberek Ankétja (absztrakt, 2007).

Johnsen, S., Gribbestad, I. S., Johansen, S. (1989) Formation of chlorinated PAH - A possible health hazard from water chlorination. Science of the Total Environment 81-82, 231-238.

Juhász, Gy. (1992) A pannóniai (s. 1.) formációk térképezése az Alföldön: elterjedés, fácies és üledékes környezet. Földtani Közlöny 122, 133-165.

Juhász, Gy. (1993) Relatív vízszintingadozások rétegtani-szedimentológiai bizonyítékai az Alföld pannóniai s. 1. üledékösszletében. Földtani Közlöny 123, 379-398.

Juhász, Gy. (1994) Magyarországi neogén medencerészek pannóniai s. 1. üledéksorának összehasonlító elemzése. Földtani Közlöny 124, 341-365. 
Juhász, Gy., Pogácsás Gy., Magyar, I., Vakarcs G. (2006) Integrált-sztratigráfiai és fejlõdéstörténeti vizsgálatok az Alföld pannóniai s. 1. rétegsorában. Földtani Közlöny 136, 51-86.

Jurg, J. W., Eisma, E. (1964) Petroleum Hydrocarbons: Generation from fatty acid. AAPG Bulletin 64, 59- 66.

Kapadia, P. R., Kallos, M. S., Gates, I. D. (2012) A new reaction model for aquathermolysis of Athabasca bitumen. The Canadian Journal of Chemical Engineering, in press. DOI: $10.1002 /$ cjce. 21662

Kárpáti Z., Klopp G. (1994a) Nagy szervesanyag tartalmú hévizek szerves nyomkomponensei. Kárpát-medence vízkészlete és vízi környezetvédelme kongresszus I-II., Magyar Hidrológiai Társaság, Eger, 1994. október 17 - 21, I. kötet, 258-271.

Kárpáti Z., Klopp G. (1994b) Identification of various organics in thermal waters containing high amount of natural organic substances. Proceedings of The 1st Hungarian Ukrainian Conference on Carpathian Euroregion Ecology, Uzhorod, May 30 - June 2, 1994. P96.

Kárpáti Z., Sajgó Cs., Vető I., Klopp G., Horváth I. (1995) Identification of various organics in thermal waters in the Pannonian Basin. Preliminary reports. In: Grimalt, J.O., Dorronsoro, C. (Eds): Organic Geochemistry Developments and applications to energy, climate, environment and human history. A. I. G. O. A. Donostia-San Sebastian, 594-596.

Kárpáti Z., Varsányi I., Klopp G. (1996a) Dél-Alföldi termálvizek szervesanyag komponensei. The 2nd Symposium on Analytical and Environmental Problems, 1996. november 4., Szeged, 109-114.

Kárpáti Z., Vető I., Sajgó Cs. (1996b) A hazai termálvizek szerves mikrokomponensösszetétel vizsgálata. Egészségtudomány XL, 356-364.

Kárpáti Z., Vetõ I., Sajgó Cs. (1996c) A hazai termálvizek szerves mikrokomponens vizsgálatainak újabb eredményei. In: Dudinszky L.-né (Ed.) A víz és a vízi környezetvédelem a Kárpát-medencében. Magyar Hidrológiai Társaság, 811-843.

Kárpáti Z. (1999) A hazai ásvány- és termálvizek szerves- és szervetlen nyomkomponens összetételének genetikai célú vizsgálata, T 014484 OTKA Zárójelentés 
Kárpáti Z., Sajgó Cs., Vető I., Klopp G., Horváth I. (1999) Organic matter in thermal waters of the Pannonian Basin - A preliminary report on aromatic compounds. Organic Geochemistry 30, 701-712.

Katritzky, A. R., Balasubramanian, M., Siskin, M. (1992) Aqueous High-Temperature Chemistry of Carbo- and heterocycles. 17. Thiophene, Tetrahydrothiophene, 2Methylthiophene, 2,5-Dimethylthiophene, Benzo[b]thiophene, and Dibenzithiophene. Energy \& Fuels, 6, 431-438.

Katritzky, A. R., Barcock, R. A., Balasubramanian, M., Greenhill, J. V., Siskin, M., Olmstead, W. N. (1994a) Aqueous High-Temperature Chemistry of Carbo- and Heterocycles. 20. Reactions of Some Benzenoid Hydrocarbons and OxygenContaining Derivatives in Supercritical Water at $460^{\circ} \mathrm{C}$. Energy \& Fuels, 8, 487497.

Katritzky, AR; Murugan, R.; Balasubramanian, M.; Siskin, M. (1994b) Aqueous HighTemperature Chemistry of Carbo- and Heterocycles. 10. Aquathermolysis of Acyclic and Cyclic Phenol Ethers in the Presence of Sodium Bisulfite or Phosphoric Acid. Energy \& Fuels, 4, 543-546

Katritzky, A. R., Ignatchenko, E. S., Allin, S. M., Barcock, R. A., Siskin, M., Hudson, C. W. (1997) Aqueous High-Temperature Chemistry of Carbo- and Heterocycles. 29.1 Reactions of Aryl Hydrocarbons, Aryl N-Oxides, and Aryl Carbonyl Compounds in Supercritical Water at $460^{\circ} \mathrm{C}$. Energy \& Fuels, 11, 160-173.

Katritzky, A. R., Nichols, D. A., Siskin, M., Murugan, R., Balasubramanian, M. (2001) Reactions in High-Temperature Aqueous Media. Chemical Reviews, 101, 837-892.

Kharaka,Y, K, Lico, M. S ., Carothers, W. W. (1980) Predicted corrosion and scaleformation properties of geopressured-geothermal waters from the northern Gulf of Mexico basin. Journal of Petroleum Technology 32, 319-324.

Kharaka, Y. K., Carothers, W. W., Rosenbauer, R. J. (1983) Thermal decarboxylation of acetic acid: Implications for origin of natural gas Geochimica et Cosmochimica Acta, 47, 397-402.

Kharaka, Y. K., Hull, R. W., Carothers, W. W. (1985) Water-rock interactions in sedimentary basins. In: Relationship of Organic Matter and Mineral Diagenesis. SEPM Short Course No. 17, 79-176. 
Kolahgar, B., Hoffmann, A., Heiden, A. C. (2002) Application of stir bar sorptive extraction to the determination of polycyclic aromatic hydrocarbons in aqueous samples. Journal of Chromatography A, 963, 225-230.

Kovács K. (2010) Dél-kelet alföldi termálvizekből kinyert humuszanyagok jellemzése. PhD Értekezés, Szegedi Tudományegyetem, 2010.

Kovács K., Gáspár A., Sajgó Cs., Schmitt-Kopplin, P., Tombácz, E. (2012) Comparative study on humic substances isolated in thermal groundwaters from deep aquifers below $700 \mathrm{~m}$. Geochemical Journal, 46, 211-224.

Kuhlmann, B., Arnett, E. M., Siskin, M. J. (1994) Classical Organic Reactions in Pure Superheated Water. Organic Chemistry, 59, 3098-3101.

Leenheer, J. A., Malcolm, R. L., Mckinley, P. L., Eccles, L. A.. (1974) Occurrence of dissolved organic carbon in selected ground water samples in the United States. USGS Journal of Research 2, 361-369.

Price, L. C. (1978) Crude oil and natural gas dissolved in deep, hot geothermal waters of petroleum basins. A possible significant new energy source. In: Meriwether, J., ed., Proceedings, Third Conference on Geopressured-Geothermal Energy, 1, GI, 167249.

Pogácsás, Gy., Lakatos, L., Révész, I., Ujszászi, K., Vakarcs, G., Várkonyi, L., Várnai, P. (1988) Seismic facies, electro facies and Neogene sequence chronology of the Pannonian Basin. Acta Geologica Hungarica 31, 175-207.

Randolph, P. (1978) Natural gas content of geopressured aquifers. In: Meriwether, J., ed., Proceedings, Third Conference on Geopressured-Geothermal Energy, 1, ES, 23-46.

Rapp, J. B. (1974) Amino acids and gases in some springs and an oil field in California. USGS Journal of Research 4, 227-232.

Rideout, D. C., Breslow, R. J. (1980) Hydrophobic acceleration of Diels-Alder reactions. Journal of American Chemical Society, 102, 7816-7817.

Rónai, A. (1985) Az Alföld negyedidőszaki földtana. Geologica Hungarica, Series Geologica, 21, p. 446.

Sajgó Cs., Kárpáti Z., Varsányi I. (2005) Organic compounds in hot thermal waters of Szentes, Hungary. In: Organic Geochemistry: Challenges for the $21^{\text {st }}$ century 
(books of Abstracts of the Communications presented to the $22^{\text {nd }}$ International Meeting on Organic Geochemistry, Seville, Spain, September 12-16, 2005.), eds.: González-Vila, F. J., González-Perez, J. A., Almendros, G.) pp 791-792.

Sajgó Cs., Kovács K., Kárpáti Z., Tombácz E., Brukner-Wein A., Fekete J. (2007a) Geochemical characterization of humic and fulvic acids of thermal waters in deep aquifers of the Pannonian Basin (SE Hungary). Book of Abstracts of the Communications presented to the $23^{\text {rd }}$ International Meeting on Organic Geochemistry Torquay, England. September $9^{\text {th }}-14^{\text {th }}$ P93-MO, 225-226.

Sajgó Cs., Kárpáti Z., Horváth I., Fekete J. (2007b) Geochemical study on organic compounds of thermal waters in deep aquifers of the Pannonian Basin. In: Book of Abstracts of the Communications presented to the $23^{\text {rd }}$ International Meeting on Organic Geochemistry Torquay, England. September 9th-14th, 2007. (eds. P. Farrimond et al.), P222-WE pp. 563-564.

Sajgó Cs., Kárpáti Z., Horváth I., Fekete J. (2008) Hévizeink oldott szerves alkotói: eredetük és jelentőségük. In: Földtudományok az emberiségért a Kárpát-medencében. Program, előadáskivonatok, HUNGEO 2008, Eötvös Workshop, Budapest (Szerk. Kovács-Pállfy P és mtsai) F3 pp. 69-70.

Sajgó Cs., Kovács K., Tombácz E., Brukner-Wein A., Kárpáti Z., Fekete J., Gáspár A., Schmitt-Kopplin, P. (2009) Organic geochemical characterization of humic and fulvic acids of thermal waters in deep aquifers of the Pannonian basin II. (SE Hungary). $24^{\text {th }}$ International Meeting on Organic Geochemistry Bremen, Germany. September $6^{\text {th }}-11^{\text {th }}, 2009$; (eds. K.-U. Hinrichs et al.) P-103, 203.

Sajgó Cs., Kárpáti Z., Horváth I., Fekete J., Kovács K., Tombácz E., Brukner-Wein A., Vető I. (2010) Hévizeink oldott szerves alkotói: eredetük és jelentőségük. In: Medencefejlődés és geológiai erőforrások: Víz, szénhidrogén, geotermikus energia (ed: Pál-Molnár E.) GeoLitera, Szeged., 2010., 96-98.

Sajgó Cs. (2010) A magyarországi termálvíz kincs szervesgeokémiai jellemzése: termálvíz kerogén/bitumen kölcsönhatás geokémiai kutatása, T48829 OTKA Zárójelentés

Schmidt, V., and McDonald, D.A. (1979) The role in secondary porosity in the course of sandstone diagenesis: SEPM Special Publication 26, 175-207. 
Siskin, M., Brons, G., Katritzky, A. R., Balasubramanian, M. (1990) Aqueous organic chemistry. 1. Aquathermolysis: comparison with thermolysis in the reactivity of aliphatic compounds. Energy \& Fuels, 4, 475-482.

Siskin, M., Katritzky, A. R. (2001) Reactivity of organic compounds in superheated water: General background. Chemical Reviews, 101, 825-835.

Su, K. W., Shen, J. C., Chang, Y. J., Huang, W. L. (2006) Generation of hydrocarbon gases and $\mathrm{CO} 2$ from a humic coal: Experimental study on the effect of water, minerals and transition metals. Organic Geochemistry 37, 437-453.

Surdam, R. C., Crossey, L. J. (1985) Organic-inorganic reactions during progressive burial: Key to porosity/permeability enhancement and/or preservation. Royal Society of London, Philosophical Transactions, 315A, p.135-156.

Thurman, M. E. (1984) Humic Substances I. Geochemistry, Characterization and Isolation: New York, Wiley \& Sons, 380 p.

Tissot, B. P., Welte, D. H. (1984) Petroleum Formation and Occurence. Springer, Berlin, $538 \mathrm{p}$.

Torry, L., A., Kaminsky, R., Klein, M. T., Klotz, M. R. (1992) The effect of salts on hydrolysis in supercritical and near-critical water: Reactivity and availability. The Journal of Supercritical Fluids, 5, 163-168.

Tóth J., Almási I. (2001) Interpretation of observed fluid potential patterns in a deep sedimentary basin under tectonic compression: Hungarian Great Plain, Pannonian Basin. Geofluids 1, 11-36.

Urbancsek J. (1977) Magyarország mélyfúrású kútjainak katasztere, VII. kötet. A pannóniai medence mélységi víztározói. Országos Vízügyi Hivatal Vízgazdálkodási Intézet, Budapest, p. 546.

Varsányi I. (1985) Humic acids in subsurface waters from the southern Great Plain, Hungary. Acta Mineralogica Petrographica, Szeged, XVII. 165-170.

Varsányi I., Bertalan-Balogi M. (1985) Humic acid as an indicator of subsurface water movements. Acta Mineralogica Petrographica, XXVII, 171-174.

Varsányi I. (1994) A Dél-Alföld felszín alatti vizei. Eredet, kémiai evolúció és vízmozgás a jelenlegi kémiai összetétel tükrében. Hidrológiai Közlöny, 74, 193-201. 
Varsányi I., Matray, J. M., Ó. Kovács L. (1997) Geochemistry of formation waters in the Pannonian Basin (Southeast-Hungary). Chemical Geology, 140, 89-106.

Varsányi I., Ó Kovács L., Kárpáti Z., Matray, J. M. (2002) Carbon forms in formation waters from the Pannonian Basin, Hungary. Chemical Geology, 189, 165-182.

Vető I., Bertalanné Balogi M. (1994) A hazai hévizes zóna kőzeteinek szerves anyaga (mennyiség, típus, érettség). Kárpát-medence vízkészlete és vízi környezetvédelme kongresszus I-II, Magyar Hidrológiai Társaság, Eger, 1994. október 17 - 21, I. kötet, 249-257.

Vető, I., Klopp, Á., Horváth, I., Kárpáti, Z. (1997) Products of early maturation of organic matter int he formation waters of SE-Hungary (Pannonian Basin). Geofluids II. '97. Contributions to the Second International Fluid Evolution, Migration and Interaction in Sedimentary Basins and Orogenic Belts (eds. Hendry, J. P., Carey, P. F., Parnell, J., Ruffell, A. H., Worden, R. H.). Belfast, Észak-Írország, 1997 március 10-17., 311-312.

Vető I, Horváth I, Tóth Gy. (1998) A szervesanyag éréstermékei az alföldi hévizekben. Hidrológiai Közlöny, 78, 240-246.

Vető I., Futó I., Horváth I., Szántó Zs. (2004a) Late and deep fermentative methanogenesis as reflected in the H-C-O-S isotopy of the methane-water system in deep aquifers of the Pannonian Basin (SE Hungary). Organic Geochemistry, 35, 713-723.

Vető I., Horváth I., Tóth Gy. (2004b) A magyarországi termálvizek geokémiájának vázlata. Magyar Kémiai Folyóirat 109-110, 199-203.

Vetter, A., Vieth-Hillebrand, A., Schettler, G., Seibt, A., Wolfgramm, M., Mangelsdorf, K. (2011) Biogeochemical monitoring of a shallow geothermally used aquifer in the North German Basin. Zeitschrift für Geologische Wissenschaften 39, 241-260.

Wakeham, S. G., Schaffner, C., Giger, W., Boon, J. J., Leeuw, J. W. D. (1979) Perylene in sediments from the Namibian Shelf. Geochimica et Cosmochimica Acta 43, 11411144.

Wakeham, S.G., Schaffner, C., Giger, W., (1980) Polycyclic aromatic hydrocarbons in recent lake sediments I. Compounds having anthropogenic origins. Geochimica et Cosmochimica Acta 44, 403-413. 
White, D.E. (1965) Saline waters of sedimentary rocks. In: Fluids in Subsurface Environments (Young, A., Galley, J. E. eds.), Memoirs - American Association of Petroleum Geologists 4., 342-366.

Willey, L. M., Kharaka, Y. K., Presser, T. S., Rapp, J. B., Barnes, I. (1975) Short chain aliphatic acid anions in oil field waters and their contribution to the measured alkalinity. Geochimica et Cosmochimica Acta 39, 1707-1711.

Zakaria, M. P., Takada, H., Tsutsumi, S., Ohno, K., Yamada, J., Kouno, E., Kumata, H. (2002) Distribution of Polycyclic Aromatic Hydrocarbons (PAHs) in Rivers and Estuaries in Malaysia: A Widespread Input of Petrogenic PAHs. Environmental Science and Technology 36, 1907-1918.

Internetes hivatkozások

http://www.ihss.gatech.edu/aquatichafa.html

http://www.ihss.gatech.edu/soilhafa.html 
Függelék: a hévizekben és a kísérletekben mért szerves vegyületek koncentrációi

\begin{tabular}{|c|c|c|c|c|c|c|c|c|c|c|c|c|}
\hline 葋 & 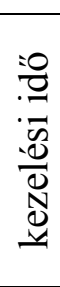 & 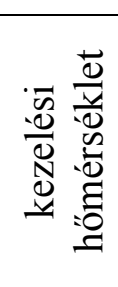 & $\begin{array}{l}\overline{8} \\
\text { 류 } \\
\end{array}$ & $\begin{array}{l}\overline{0} \\
\stackrel{0}{9}\end{array}$ & 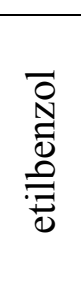 & \begin{tabular}{l}
0 \\
\hdashline $\bar{a}$ \\
$\vdots$ \\
0 \\
$\infty$ \\
0 \\
1 \\
$\vdots$
\end{tabular} & $\begin{array}{l}\overrightarrow{0} \\
\stackrel{\bar{\lambda}}{\hat{x}} \\
0\end{array}$ & . & 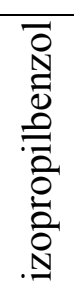 & 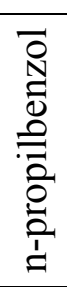 & 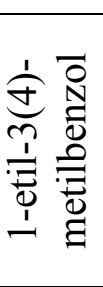 & 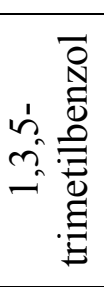 \\
\hline FA & 72 & $220^{\circ} \mathrm{C}$ & 0,6 & 1,9 & 0,2 & 0,3 & 0,1 & 4,0 & 0,0 & 0,0 & 0,0 & 0,0 \\
\hline FA & 72 & $250^{\circ} \mathrm{C}$ & 1,1 & 9,1 & 0,8 & 0,5 & 0,4 & 11,5 & 0,0 & 0,0 & 0,1 & 0,0 \\
\hline FA & 72 & $300^{\circ} \mathrm{C}$ & 61,8 & 60,0 & 10,5 & 7,0 & 9,8 & 26,6 & 0,3 & 0,5 & 2,7 & 0,4 \\
\hline FA & 72 & $320^{\circ} \mathrm{C}$ & 355,9 & 98,7 & 23,2 & 15,4 & 24,5 & 26,7 & 0,7 & 1,0 & 6,7 & 1,0 \\
\hline HAFA & 72 & $220^{\circ} \mathrm{C}$ & 0,8 & 0,9 & 0,4 & 0,4 & 0,8 & 0,7 & 0,0 & 0,0 & 0,1 & 0,1 \\
\hline HAFA & 72 & $250^{\circ} \mathrm{C}$ & 6,3 & 29,2 & 3,6 & 13,7 & 10,3 & 5,4 & 0,3 & 0,3 & 5,1 & 1,1 \\
\hline HAFA & 72 & $300^{\circ} \mathrm{C}$ & 13,6 & 32,8 & 4,1 & 13,4 & 10,6 & 6,1 & 0,5 & 0,4 & 4,7 & 1,3 \\
\hline HAFA & 72 & $320^{\circ} \mathrm{C}$ & 37,2 & 82,0 & 13,1 & 31,8 & 27,3 & 20,2 & 0,8 & 0,8 & 12,2 & 2,0 \\
\hline HA & 72 & $220^{\circ} \mathrm{C}$ & 1,2 & 2,9 & 0,9 & 0,7 & 0,4 & 18,4 & 0,0 & 0,0 & 0,5 & 0,1 \\
\hline HA & 72 & $250^{\circ} \mathrm{C}$ & 2,5 & 19,6 & 7,6 & 1,4 & 1,2 & 58,4 & 0,0 & 0,0 & 0,7 & 0,1 \\
\hline $\mathrm{HA}$ & 72 & $300^{\circ} \mathrm{C}$ & 7,9 & 77,5 & 35,7 & 7,2 & 13,8 & 57,0 & 0,4 & 0,7 & 4,2 & 0,4 \\
\hline HA & 72 & $320^{\circ} \mathrm{C}$ & 15,5 & 76,5 & 43,6 & 9,8 & 20,7 & 17,6 & 0,5 & 1,0 & 5,9 & 0,5 \\
\hline SZÉN & 72 & $220^{\circ} \mathrm{C}$ & 3,4 & 1,3 & 0,1 & 0,2 & 0,1 & 0,9 & 0,0 & 0,0 & 0,0 & 0,0 \\
\hline SZEN & 72 & $250^{\circ} \mathrm{C}$ & 1,7 & 1,8 & 0,1 & 0,1 & 0,1 & 0,5 & 0,0 & 0,0 & 0,0 & 0,0 \\
\hline SZEN & 72 & $300^{\circ} \mathrm{C}$ & 8,4 & 10,2 & 1,4 & 2,6 & 3,5 & 1,7 & 0,0 & 0,1 & 0,5 & 0,2 \\
\hline SZEN & 72 & $320^{\circ} \mathrm{C}$ & 13,0 & 18,3 & 2,9 & 4,1 & 7,1 & 1,6 & 0,1 & 0,2 & 0,8 & 0,4 \\
\hline BIT & 72 & $220^{\circ} \mathrm{C}$ & 1,6 & 0,7 & 0,2 & 0,4 & 0,1 & 0,9 & 0,0 & 0,0 & 0,1 & 0,0 \\
\hline BIT & 72 & $250^{\circ} \mathrm{C}$ & 4,5 & 4,1 & 0,8 & 2,2 & 1,2 & 3,1 & 0,1 & 0,1 & 0,7 & 0,2 \\
\hline BIT & 72 & $300^{\circ} \mathrm{C}$ & 6,6 & 21,7 & 3,9 & 15,1 & 10,1 & 5,3 & 0,4 & 0,5 & 5,7 & 1,0 \\
\hline BIT & 72 & $320^{\circ} \mathrm{C}$ & 13,1 & 22,6 & 7,7 & 18,3 & 19,3 & 5,9 & 0,9 & 0,9 & 11,4 & 1,3 \\
\hline CSAP & 72 & $220^{\circ} \mathrm{C}$ & 0,8 & 6,8 & 0,2 & 0,9 & 0,1 & 31,4 & 0,0 & 0,0 & 0,0 & 0,0 \\
\hline CSAP & 72 & $250^{\circ} \mathrm{C}$ & 1,4 & 56,9 & 4,2 & 2,2 & 0,4 & 177,3 & 0,0 & 0,0 & 0,0 & 0,0 \\
\hline CSAP & 72 & $300^{\circ} \mathrm{C}$ & 3,3 & 94,8 & 13,7 & 2,8 & 1,8 & 118,5 & 0,2 & 0,0 & 0,8 & 0,1 \\
\hline CSAP & 72 & $320^{\circ} \mathrm{C}$ & 12,6 & 115,9 & 25,5 & 4,8 & 3,2 & 106,8 & 0,3 & 0,0 & 1,4 & 0,3 \\
\hline FA & 24 & $220^{\circ} \mathrm{C}$ & 0,6 & 1,3 & 0,4 & 0,4 & 0,3 & 4,6 & 0,0 & 0,0 & 0,2 & 0,0 \\
\hline FA & 24 & $250^{\circ} \mathrm{C}$ & 0,9 & 7,0 & 1,1 & 1,1 & 0,8 & 27,6 & 0,0 & 0,0 & 0,4 & 0,1 \\
\hline FA & 24 & $300^{\circ} \mathrm{C}$ & 16,8 & 31,5 & 6,2 & 3,3 & 6,1 & 43,3 & 0,1 & 0,3 & 2,0 & 0,2 \\
\hline FA & 24 & $320^{\circ} \mathrm{C}$ & 99,6 & 47,9 & 15,2 & 7,3 & 17,4 & 45,7 & 0,2 & 0,6 & 4,1 & 0,3 \\
\hline
\end{tabular}

Függelék 1. Táblázat. Benzol és alkilbenzolok koncentrációi ( $\mu \mathrm{g} / \mathrm{l})$ a kísérletekben I. 


\begin{tabular}{|c|c|c|c|c|c|c|c|c|c|c|c|c|c|}
\hline 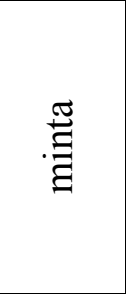 & 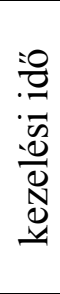 & 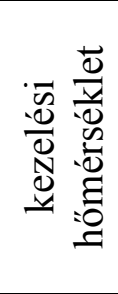 & 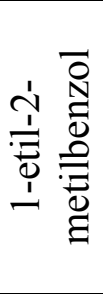 & 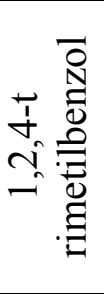 & 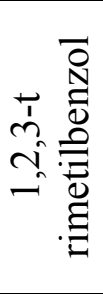 & 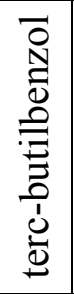 & 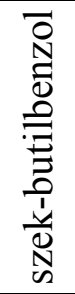 & 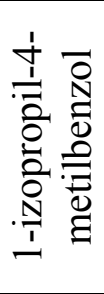 & 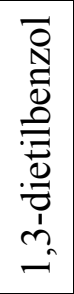 & 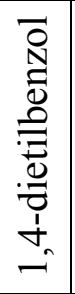 & 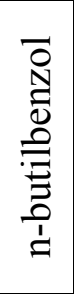 & 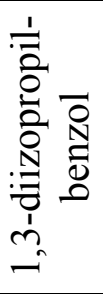 & 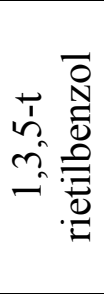 \\
\hline FA & & $0^{\circ}$ & 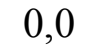 & 0,1 & 0,1 & 0,0 & 0,0 & 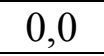 & 0,0 & 0,0 & 0,0 & 0,0 &, 0 \\
\hline FA & 2 & $50^{\circ} \mathrm{C}$ & 0 & 0 & 0,2 & 0 & 0,0 & 0,0 & 0,0 & 0,0 & 0,0 & 0,0 &, 0 \\
\hline FA & 2 & $00^{\circ} \mathrm{C}$ & 1,3 & 4,7 & 3 , & 0,0 & 0,0 & 0,4 & 0,8 & 0,3 & 0,0 & 0,0 & 0,0 \\
\hline FA & 2 & $20^{\circ} \mathrm{C}$ & 2.7 & 10,4 & 9,9 & 0 & 0,0 & 0,8 & 0,0 & 0,8 & 0,0 & 0,0 & 0,0 \\
\hline HAFA & 2 & $20^{\circ} \mathrm{C}$ & 0,1 & 0 & 0,7 & 0,0 & 0,0 & 0,0 & 0,0 & 0,0 & 0,0 & 0,0 & 0,0 \\
\hline $\mathrm{HAF}$ & 2 & $50^{\circ} \mathrm{C}$ & 1,5 & 11,7 & 9,6 & 0 & 0,0 & 0,4 & 0,0 & 0,0 & 0,0 & 0,0 & , \\
\hline HAFA & 72 & $00^{\circ} \mathrm{C}$ & 1,7 & 11,1 & 8, & 0,0 & 0,0 & 0,7 & 0,0 & 0,0 & 0,0 & 0,0 & 0,0 \\
\hline HAFA & 2 & $20^{\circ} \mathrm{C}$ & 3,4 & 22 & 17,3 & 0 & 0,0 & 1, & 0,0 & 0,0 & 0,0 & 0,0 & 0,0 \\
\hline HA & 72 & $20^{\circ} \mathrm{C}$ & 0,1 & 0,6 & 0,4 & 0,0 & 0,0 & 0,4 & 0,0 & 0,0 & 0,0 & 0,0 & 0,0 \\
\hline $\mathrm{HA}$ & 2 & 50 & 0 & & 1,4 & 0 & 0,0 & 0 & 0,0 & 0,0 & 0,0 & c &, 0 \\
\hline HA & 72 & $00^{\circ} \mathrm{C}$ & 1,1 & 6,2 & 3,5 & 0,0 & 0,0 & 0,7 & 1,7 & 0,2 & 0,0 & 0,0 & 0,0 \\
\hline $\mathrm{HA}$ & 2 & $20^{\circ} \mathrm{C}$ & 1,3 & 8 & 5. & 0 & 0,0 & 0 , & 2,6 & 0,4 & 0,0 & 0,0 & 0,0 \\
\hline SZÉN & 72 & $20^{\circ} \mathrm{C}$ & 0,0 & 0,2 & 0,1 & 0,0 & 0,0 & 0,0 & 0,0 & 0,0 & 0,0 & 0,0 & 0,0 \\
\hline SZEN & 2 & $50^{\circ} \mathrm{C}$ & 0 , & 0,1 & 0 . & 0 & 0,0 & 0 , & 0,0 & 0,0 & 0,0 & 0 & 0.0 \\
\hline SZEN & 72 & $00^{\circ} \mathrm{C}$ & 0,3 & 2,0 & 2, & 0,0 & 0,0 & 0 , & 0,1 & 0,1 & 0,0 & 0,0 & 0,0 \\
\hline SZEN & 72 & $20^{\circ} \mathrm{C}$ & 0 & 3 , & 3. & 0,0 & 0,0 & 0. & 0,2 & 0,1 & 0,0 & 0. & 0.0 \\
\hline BIT & 72 & $20^{\circ} \mathrm{C}$ & 0, & 0,2 & 0,4 & 0,0 & 0,0 & 0 , & 0,0 & 0,0 & 0,0 & 0,0 & 0,0 \\
\hline BIT & 72 & $50^{\circ} \mathrm{C}$ & 0,2 & 0,9 & 2,6 & 0,0 & 0,0 & 0 , & 0,0 & 0,0 & 0,0 & 0,0 & 0,0 \\
\hline BIT & 72 & $00^{\circ} \mathrm{C}$ & 1,2 & & 17,1 & 0,0 & 0,0 & 2, & 0,0 & 0,0 & 0,2 & 0,0 & 0,0 \\
\hline BIT & 72 & $20^{\circ} \mathrm{C}$ & 1,8 & 15,4 & 19,9 & 0,0 & 0,0 & 4. & 0,0 & 0,0 & 0,4 & 0,0 & 0,0 \\
\hline CSAP & 72 & $220^{\circ} \mathrm{C}$ & 0,0 & 0,0 & 0,0 & 0,0 & 0,0 & 0 , & 0,0 & 0,0 & 0,0 & 0,0 & 0,0 \\
\hline CSAP & 72 & $250^{\circ} \mathrm{C}$ & 0,0 & 0,0 & 0,0 & 0,0 & 0,0 & 0.1 & 0,0 & 0,0 & 0,0 & 0,0 & 0,0 \\
\hline CSAP & 72 & $300^{\circ} \mathrm{C}$ & 0,3 & 0,8 & 0,0 & 0,0 & 0,0 & 0 , & 0,0 & 0,0 & 0,2 & 0,0 & 0,0 \\
\hline CSAP & 72 & $320^{\circ} \mathrm{C}$ & 0,6 & 1,6 & 0,0 & 0,0 & 0,0 & 0,4 & 0,0 & 0,0 & 0,1 & 0,0 & 0,0 \\
\hline FA & 24 & $220^{\circ} \mathrm{C}$ & 0,0 & 0,3 & 0,3 & 0,0 & 0,0 & 0,0 & 0,0 & 0,0 & 0,0 & 0,0 & 0,0 \\
\hline FA & 24 & $250^{\circ} \mathrm{C}$ & 0,1 & 0,7 & 0,4 & 0,0 & 0,0 & 0,1 & 0,0 & 0,0 & 0,0 & 0,0 & 0,0 \\
\hline FA & 24 & $300^{\circ} \mathrm{C}$ & 0,6 & 3,1 & 1,5 & 0,0 & 0,0 & 0,2 & 0,5 & 0,1 & 0,0 & 0,0 & 0,0 \\
\hline FA & 21 & $320^{\circ} \mathrm{C}$ & 1,3 & 7,8 & 3,2 & 0,0 & 0,0 & 0,5 & 1,1 & 0,3 & 0,0 & 0,0 & 0,0 \\
\hline
\end{tabular}

Függelék 2. Táblázat. Benzol és alkilbenzolok koncentrációi $(\mu \mathrm{g} / 1)$ a kísérletekben II. 


\begin{tabular}{|c|c|c|c|c|c|c|c|c|c|c|c|}
\hline . & 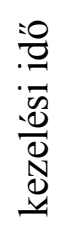 & 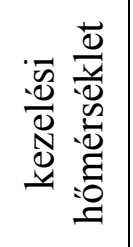 & 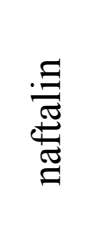 & 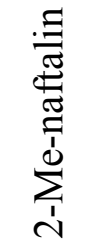 & 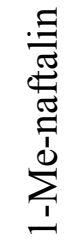 & 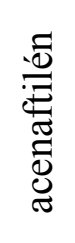 & 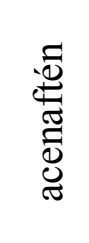 & 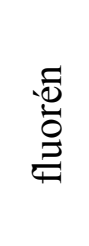 & 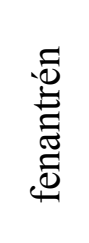 & 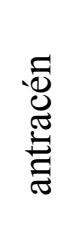 & \\
\hline FA & 72 & $220^{\circ} \mathrm{C}$ & 3,1 & 4,8 & 1,7 & 0,2 & 1,2 & 2,3 & 7,5 & 0,1 & $\overline{1,8}$ \\
\hline FA & 72 & $250^{\circ} \mathrm{C}$ & 4,8 & 8,6 & 2,4 & 0,3 & 1,5 & 3,5 & 7,9 & 0,1 & 1,9 \\
\hline FA & 72 & $300^{\circ} \mathrm{C}$ & 7,4 & 11,2 & 4,1 & 0,5 & 7,4 & 8,7 & 7,5 & 0,8 & 3,0 \\
\hline FA & 72 & $320^{\circ} \mathrm{C}$ & 16,7 & 18,5 & 8,9 & 1,1 & 17,6 & 16,7 & 7,8 & 2,3 & 4,3 \\
\hline HAFA & 72 & $220^{\circ} \mathrm{C}$ & 4,8 & 8,2 & 2,9 & 0,3 & 1,3 & 2,9 & 11,0 & 0,1 & 0,9 \\
\hline HAFA & 72 & $250^{\circ} \mathrm{C}$ & 6,4 & 12,5 & 4,0 & 0,6 & 1,5 & 6,2 & 12,9 & 0,2 & 1,0 \\
\hline HAFA & 72 & $300^{\circ} \mathrm{C}$ & 12,3 & 17,8 & 8,5 & 4,7 & 11,7 & 47,4 & 14,2 & 0,7 & 1,9 \\
\hline HAFA & 72 & $320^{\circ} \mathrm{C}$ & 44,3 & 40,5 & 24,9 & 6,6 & 23,4 & 79,9 & 15,6 & 1,9 & 4,1 \\
\hline HA & 72 & $220^{\circ} \mathrm{C}$ & 1,3 & 0,6 & 0,7 & 0,1 & 0,3 & 0,4 & 2,5 & 0,2 & 0,3 \\
\hline $\mathrm{HA}$ & 72 & $250^{\circ} \mathrm{C}$ & 1,5 & 1,2 & 0,9 & 0,1 & 0,7 & 1,1 & 0,8 & 0,1 & 0,3 \\
\hline $\mathrm{HA}$ & 72 & $300^{\circ} \mathrm{C}$ & 3,6 & 3,1 & 2,1 & 0,3 & 2,3 & 3,2 & 4,2 & 1,0 & 0,9 \\
\hline HA & 72 & $320^{\circ} \mathrm{C}$ & 7,7 & 6,1 & 4,2 & 0,6 & 5,2 & 5,5 & 4,1 & 1,4 & 1,3 \\
\hline SZÉN & 72 & $220^{\circ} \mathrm{C}$ & 4,1 & 9,0 & 3,5 & 0,1 & 4,0 & 3,2 & 16,0 & 0,4 & 1,6 \\
\hline SZEN & 72 & $250^{\circ} \mathrm{C}$ & 4,2 & 10,0 & 3,7 & 0,1 & 3,6 & 2,8 & 14,0 & 0,3 & 1,6 \\
\hline SZEN & 72 & $300^{\circ} \mathrm{C}$ & 5,3 & 12,9 & 5,1 & 0,4 & 10,8 & 7,8 & 14,4 & 0,8 & 2,1 \\
\hline SZEN & 72 & $320^{\circ} \mathrm{C}$ & 10,0 & 19,4 & 8,6 & 0,9 & 25,5 & 10,9 & 12,6 & 2,0 & 2,3 \\
\hline BIT & 72 & $220^{\circ} \mathrm{C}$ & 0,5 & 0,3 & 0,2 & 0,0 & 0,0 & 0,4 & 7,0 & 0,0 & 1,3 \\
\hline BIT & 72 & $250^{\circ} \mathrm{C}$ & 0,8 & 0,7 & 0,6 & 0,1 & 0,2 & 1,3 & 8,6 & 0,5 & 1,5 \\
\hline BIT & 72 & $300^{\circ} \mathrm{C}$ & 3,3 & 4,6 & 3,8 & 0,5 & 1,0 & 2,6 & 10,1 & 1,1 & 1,6 \\
\hline BIT & 72 & $320^{\circ} \mathrm{C}$ & 12,2 & 14,5 & 12,4 & 2,4 & 5,3 & 3,6 & 11,8 & 1,3 & 1,8 \\
\hline CSAP & 72 & $220^{\circ} \mathrm{C}$ & 0,4 & 0,2 & 0,1 & 0,0 & 0,1 & 0,2 & 0,3 & 0,1 & 0,2 \\
\hline CSAP & 72 & $250^{\circ} \mathrm{C}$ & 1,1 & 0,5 & 0,4 & 0,2 & 0,8 & 0,8 & 0,5 & 0,2 & 0,3 \\
\hline CSAP & 72 & $300^{\circ} \mathrm{C}$ & 1,2 & 1,4 & 1,1 & 0,2 & 1,4 & 1,7 & 0,7 & 0,3 & 0,5 \\
\hline CSAP & 72 & $320^{\circ} \mathrm{C}$ & 4,0 & 3,5 & 3,4 & 0,5 & 3,5 & 3,0 & 1,6 & 1,2 & 1,1 \\
\hline FA & 24 & $220^{\circ} \mathrm{C}$ & 2,2 & 0,6 & 0,3 & 0,1 & 0,3 & 0,5 & 2,5 & 0,2 & 0,4 \\
\hline FA & 24 & $250^{\circ} \mathrm{C}$ & 1,8 & 0,6 & 0,3 & 0,1 & 0,6 & 0,9 & 2,8 & 0,2 & 0,6 \\
\hline FA & 24 & $300^{\circ} \mathrm{C}$ & 2,2 & 0,7 & 0,3 & 0,2 & 0,8 & 1,3 & 2,7 & 0,3 & 0,7 \\
\hline FA & 24 & $320^{\circ} \mathrm{C}$ & 4,1 & 3,2 & 2,4 & 0,5 & 5,4 & 7,5 & 3,1 & 0,8 & 1,0 \\
\hline
\end{tabular}

Függelék 3. Táblázat. PAH-ok koncentrációi $(\mu \mathrm{g} / \mathrm{l})$ a kísérletekben I. 


\begin{tabular}{|c|c|c|c|c|c|c|c|c|c|c|c|}
\hline$\stackrel{\stackrel{\Xi}{\Xi}}{\Xi}$ & 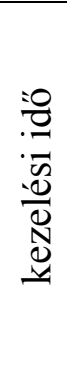 & 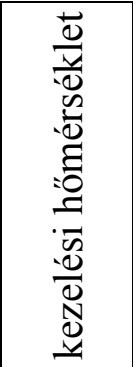 & : & 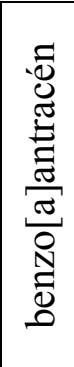 & $\begin{array}{l}\stackrel{\mathbb{N}}{\mathbb{N}} \\
\underline{\Xi}\end{array}$ & 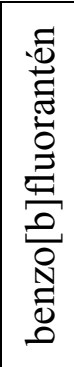 & 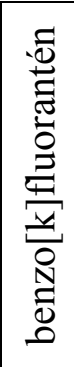 & 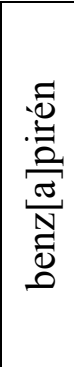 & 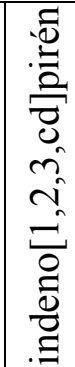 & 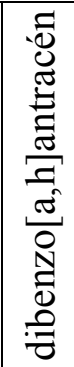 & 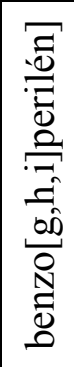 \\
\hline FA & 72 & $220^{\circ} \mathrm{C}$ & 0,8 & 0,0 & 0,1 & 0,0 & 0,0 & 0,0 & 0,0 & 0,0 & 0,0 \\
\hline FA & 72 & $250^{\circ} \mathrm{C}$ & 1,0 & 0,0 & 0,1 & 0,0 & 0,0 & 0,0 & 0,0 & 0,0 & 0,0 \\
\hline FA & 72 & $300^{\circ} \mathrm{C}$ & 1,2 & 0,1 & 0,1 & 0,0 & 0,0 & 0,0 & 0,0 & 0,0 & 0,0 \\
\hline FA & 72 & $320^{\circ} \mathrm{C}$ & 2,0 & 0,2 & 0,1 & 0,0 & 0,0 & 0,0 & 0,0 & 0,0 & 0,0 \\
\hline HAFA & 72 & $220^{\circ} \mathrm{C}$ & 0,4 & 0,0 & 0,1 & 0,0 & 0,0 & 0,0 & 0,0 & 0,0 & 0,0 \\
\hline HAFA & 72 & $250^{\circ} \mathrm{C}$ & 0,5 & 0,0 & 0,1 & 0,0 & 0,0 & 0,0 & 0,0 & 0,0 & 0,0 \\
\hline HAFA & 72 & $300^{\circ} \mathrm{C}$ & 1,0 & 0,1 & 0,2 & 0,1 & 0,1 & 0,1 & 0,0 & 0,0 & 0,0 \\
\hline HAFA & 72 & $320^{\circ} \mathrm{C}$ & 2,1 & 0,5 & 0,3 & 0,2 & 0,1 & 0,1 & 0,0 & 0,0 & 0,0 \\
\hline HA & 72 & $220^{\circ} \mathrm{C}$ & 0,3 & 0,0 & 0,2 & 0,0 & 0,0 & 0,0 & 0,0 & 0,0 & 0,0 \\
\hline HA & 72 & $250^{\circ} \mathrm{C}$ & 0,3 & 0,1 & 0,1 & 0,0 & 0,0 & 0,0 & 0,0 & 0,0 & 0,0 \\
\hline HA & 72 & $300^{\circ} \mathrm{C}$ & 0,8 & 0,1 & 0,1 & 0,0 & 0,0 & 0,0 & 0,0 & 0,0 & 0,0 \\
\hline $\mathrm{HA}$ & 72 & $320^{\circ} \mathrm{C}$ & 1,2 & 0,1 & 0,2 & 0,0 & 0,0 & 0,0 & 0,0 & 0,0 & 0,0 \\
\hline SZÉN & 72 & $220^{\circ} \mathrm{C}$ & 0,8 & 0,1 & 0,1 & 0,1 & 0,0 & 0,0 & 0,2 & 0,2 & 0,1 \\
\hline SZEN & 72 & $250^{\circ} \mathrm{C}$ & 0,8 & 0,1 & 0,1 & 0,1 & 0,0 & 0,1 & 0,3 & 0,2 & 0,1 \\
\hline SZEN & 72 & $300^{\circ} \mathrm{C}$ & 1,4 & 0,2 & 0,2 & 0,1 & 0,1 & 0,1 & 0,5 & 0,3 & 0,3 \\
\hline SZEN & 72 & $320^{\circ} \mathrm{C}$ & 2,3 & 0,3 & 0,2 & 0,1 & 0,1 & 0,1 & 0,3 & 0,2 & 0,1 \\
\hline BIT & 72 & $220^{\circ} \mathrm{C}$ & 1,8 & 0,3 & 0,4 & 0,0 & 0,0 & 0,0 & 0,0 & 0,0 & 0,0 \\
\hline BIT & 72 & $250^{\circ} \mathrm{C}$ & 2,1 & 0,4 & 0,4 & 0,1 & 0,0 & 0,1 & 0,0 & 0,0 & 0,0 \\
\hline BIT & 72 & $300^{\circ} \mathrm{C}$ & 2,4 & 0,4 & 0,3 & 0,0 & 0,0 & 0,1 & 0,0 & 0,0 & 0,0 \\
\hline BIT & 72 & $320^{\circ} \mathrm{C}$ & 3,2 & 0,5 & 0,4 & 0,0 & 0,0 & 0,1 & 0,0 & 0,0 & 0,0 \\
\hline CSAP & 72 & $220^{\circ} \mathrm{C}$ & 0,5 & 0,0 & 0,2 & 0,1 & 0,0 & 0,1 & 0,0 & 0,0 & 0,0 \\
\hline CSAP & 72 & $250^{\circ} \mathrm{C}$ & 0,5 & 0,0 & 0,1 & 0,0 & 0,0 & 0,0 & 0,0 & 0,0 & 0,0 \\
\hline CSAP & 72 & $300^{\circ} \mathrm{C}$ & 0,6 & 0,0 & 0,1 & 0,0 & 0,0 & 0,0 & 0,0 & 0,0 & 0,0 \\
\hline CSAP & 72 & $320^{\circ} \mathrm{C}$ & 1,4 & 0,0 & 0,2 & 0,0 & 0,0 & 0,0 & 0,0 & 0,0 & 0,0 \\
\hline FA & 24 & $220^{\circ} \mathrm{C}$ & 0,3 & 0,0 & 0,1 & 0,0 & 0,0 & 0,0 & 0,0 & 0,0 & 0,0 \\
\hline FA & 24 & $250^{\circ} \mathrm{C}$ & 0,3 & 0,0 & 0,1 & 0,0 & 0,0 & 0,0 & 0,0 & 0,0 & 0,0 \\
\hline FA & 24 & $300^{\circ} \mathrm{C}$ & 0,4 & 0,0 & 0,1 & 0,0 & 0,0 & 0,0 & 0,0 & 0,0 & 0,0 \\
\hline FA & 24 & $320^{\circ} \mathrm{C}$ & 0,7 & 0,1 & 0,1 & 0,0 & 0,0 & 0,0 & 0,0 & 0,0 & 0,0 \\
\hline
\end{tabular}

Függelék 4. Táblázat. PAH-ok koncentrációi $(\mu \mathrm{g} / 1)$ a kísérletekben II. 


\begin{tabular}{|c|c|c|c|c|c|c|c|c|c|}
\hline 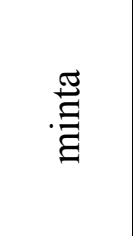 & 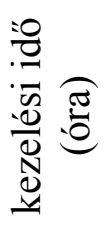 & 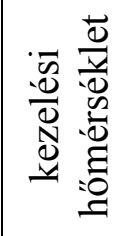 & $\begin{array}{l}\overrightarrow{0} \\
\stackrel{0}{U}\end{array}$ & $\begin{array}{l}\overline{0} \\
\stackrel{0}{0} \\
\frac{1}{1} \\
\overline{0} \\
\stackrel{0}{0} \\
\stackrel{1}{v}\end{array}$ & 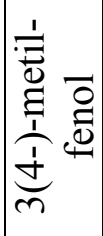 & 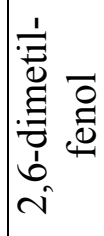 & 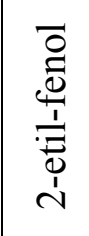 & 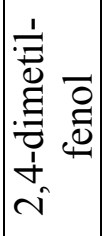 & 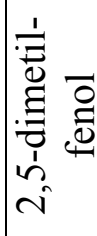 \\
\hline FA & 72 & $20^{\circ} \mathrm{C}$ & 0,12 & 0 & 0 & 0 & 0 & 0 & 0 \\
\hline FA & 72 & $50^{\circ} \mathrm{C}$ & 0,03 & 0,02 & 0 & 0 & 0 & 0 & 0 \\
\hline FA & 72 & $00^{\circ} \mathrm{C}$ & 0,03 & 0,08 & 0,01 & 0,06 & 0,01 & 0 & 0,02 \\
\hline FA & 72 & $320^{\circ} \mathrm{C}$ & 0,04 & 0,17 & 0,02 & 0,11 & 0,02 & 0,03 & 0,02 \\
\hline HAFA & 72 & $20^{\circ} \mathrm{C}$ & 0 & 0,01 & 0 & 0 & 0 & & 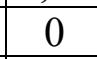 \\
\hline HAFA & 72 & $250^{\circ} \mathrm{C}$ & 0,01 & 0 & 0 & 0 & 0 & ( & 0 \\
\hline HAF & 72 & $0^{\circ} \mathrm{C}$ & 0,05 &, 05 & 0,01 & 0,01 & 0 & & $\Omega_{1}$ \\
\hline HAFA & 72 & $320^{\circ} \mathrm{C}$ & 0,14 & 0,12 & 0,04 & 0,01 & 0,01 & ( & 0,01 \\
\hline HA & 72 & $220^{\circ} \mathrm{C}$ & 0,41 & 0,03 & 0,01 & 0,01 & 0 & c & 0 \\
\hline $\mathrm{HA}$ & 72 & $50^{\circ} \mathrm{C}$ & 0,52 & 0,05 & 0,03 & 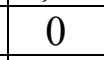 & 0 & & 0 \\
\hline $\mathrm{HA}$ & 72 & $300^{\circ} \mathrm{C}$ & 0,91 & 0,25 & 0,13 & 0 & 0,01 & 0 & 0,02 \\
\hline $\mathrm{HA}$ & 72 & $320^{\circ} \mathrm{C}$ & 0,3 & 0,24 & 0,09 & 0,02 & 0,02 & 0,05 & 0,02 \\
\hline SZÉN & 72 & $220^{\circ} \mathrm{C}$ & 0 & 0 & 0 & 0 & 0 & \begin{tabular}{|l|}
0 \\
\end{tabular} & 0 \\
\hline SZEN & 72 & $250^{\circ} \mathrm{C}$ & 0,02 & 0,02 & 0 & 0 & 0 & & 0 \\
\hline SZEN & 72 & $300^{\circ} \mathrm{C}$ & 0,03 & 0,08 & 0,01 & 0,03 & 0,01 & 0,01 & 0,01 \\
\hline SZEN & 72 & $320^{\circ} \mathrm{C}$ & 0,03 & 0,11 & 0 & 0,04 & 0,01 & 0,01 & 0,01 \\
\hline BIT & 72 & $220^{\circ} \mathrm{C}$ & 0,01 & 0,01 & 0 & 0 & 0 & 0 & 0 \\
\hline BIT & 72 & $250^{\circ} \mathrm{C}$ & 0,01 & 0,04 & 0,01 & 0,01 & 0,01 & 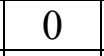 & 0,01 \\
\hline BIT & 72 & $300^{\circ} \mathrm{C}$ & 0,03 & 0,1 & 0,05 & 0,05 & 0,02 & 0,03 & 0,02 \\
\hline BIT & 72 & $320^{\circ} \mathrm{C}$ & 0,08 & 0,21 & 0,1 & 0,07 & 0,03 & 0,04 & 0,03 \\
\hline CSAP & 72 & $220^{\circ} \mathrm{C}$ & 0 & 0 & 0 & 0 & 0 & 0 & 0 \\
\hline CSAP & 72 & $250^{\circ} \mathrm{C}$ & 0 & 0 & 0 & 0 & 0 & - & 0 \\
\hline CSAP & 72 & $300^{\circ} \mathrm{C}$ & 0,02 & 0,02 & 0 & 0,02 & 0 & 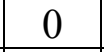 & 0 \\
\hline CSAP & 72 & $320^{\circ} \mathrm{C}$ & 0,01 & 0,02 & 0 & 0,02 & 0 & 0 & 0,01 \\
\hline FA & 24 & $220^{\circ} \mathrm{C}$ & 0,04 & 0 & 0 & 0 & 0 & 0 & 0 \\
\hline FA & 24 & $250^{\circ} \mathrm{C}$ & 0,06 & 0,02 & 0 & 0 & 0 & 0 & 0 \\
\hline FA & 24 & $300^{\circ} \mathrm{C}$ & 0,12 & 0,09 & \begin{tabular}{|l|}
0,02 \\
\end{tabular} & 0,01 & 0,01 & \begin{tabular}{|l|}
0,01 \\
\end{tabular} & 0,01 \\
\hline
\end{tabular}

Függelék 5. Táblázat. Fenolok koncentrációi (mg/l) a kísérletekben I. 


\begin{tabular}{|c|c|c|c|c|c|c|c|c|}
\hline 穂 & 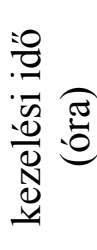 & 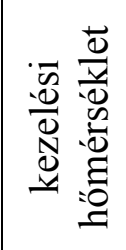 & 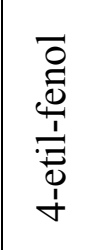 & 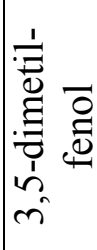 & 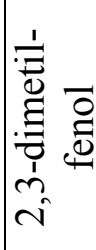 & 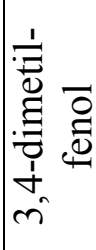 & 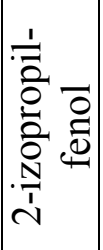 & 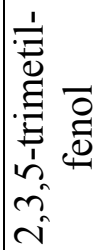 \\
\hline FA & 72 & $0^{\circ} \mathrm{C}$ & 0 & 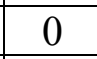 & 0 & 0 & 0 & 0 \\
\hline FA & 72 & $50^{\circ} \mathrm{C}$ & 0 & 0 & 0 & & 0 & 0 \\
\hline FA & 72 & $00^{\circ} \mathrm{C}$ & 0 & 0 & 0 & 0 & 0 & 0 \\
\hline FA & 72 & $320^{\circ} \mathrm{C}$ & 0 & 0 & 0,01 & 0 & 0 & 0 \\
\hline HAFA & 72 & $20^{\circ} \mathrm{C}$ & 0 & 0 & 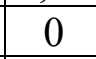 & 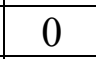 & 0 & 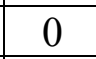 \\
\hline HAFA & 72 & $250^{\circ} \mathrm{C}$ & 0 & 0 & 0 & 0 & 0 & 0 \\
\hline HAFA & 72 & $0^{\circ} \mathrm{C}$ & 0 & 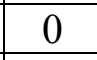 & 0 & & 0 & 0 \\
\hline HAFA & 72 & $320^{\circ} \mathrm{C}$ & 0 & 0,01 & 0 & 0 & 0 & 0 \\
\hline HA & 72 & $220^{\circ} \mathrm{C}$ & 0 & 0 & 0 & 0 & 0 & 0 \\
\hline $\mathrm{HA}$ & 72 & $250^{\circ} \mathrm{C}$ & 0 & 0 & 0 & 0 & 0 & 0 \\
\hline $\mathrm{HA}$ & 72 & $300^{\circ} \mathrm{C}$ & 0 & 0 & 0 & 0 & 0 & 0 \\
\hline $\mathrm{HA}$ & 72 & $320^{\circ} \mathrm{C}$ & 0 & 0,01 & 0 & ( & 0 & 0 \\
\hline SZÉN & 72 & $220^{\circ} \mathrm{C}$ & 0 & 8 & 0 & 0 & 0 & 0 \\
\hline SZEN & 72 & $250^{\circ} \mathrm{C}$ & 0 & 0 & $=$ & 0 & 0 & 0 \\
\hline SZEN & 72 & $300^{\circ} \mathrm{C}$ & 0 & 0 & 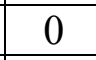 & 0 & 0,01 & 0,01 \\
\hline SZEN & 72 & $320^{\circ} \mathrm{C}$ & 0 & 0 & 0,01 & 0 & 0,01 & 0,01 \\
\hline BIT & 72 & $220^{\circ} \mathrm{C}$ & 0 & 0 & 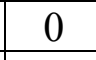 & 0 & 0 & 0 \\
\hline BIT & 72 & $250^{\circ} \mathrm{C}$ & 0 & 0,01 & 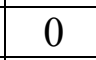 & 0 & 0,01 & 0 \\
\hline BIT & 72 & $300^{\circ} \mathrm{C}$ & 0,12 & 0,02 & 0,01 & 0,02 & 0,03 & 0 \\
\hline BIT & 72 & $320^{\circ} \mathrm{C}$ & 0 & 0,03 & 0,01 & 0,02 & 0,04 & 0,02 \\
\hline CSAP & 72 & $220^{\circ} \mathrm{C}$ & 0 & 0 & 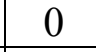 & r & 0 & 0 \\
\hline CSAP & 72 & $250^{\circ} \mathrm{C}$ & 0 & 0 & 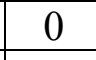 & 0 & 0 & 0 \\
\hline CSAP & 72 & $300^{\circ} \mathrm{C}$ & 0 & 0 & 0 & 0 & 0 & 0 \\
\hline CSAP & 72 & $320^{\circ} \mathrm{C}$ & 0 & 0 & 0 & 0 & 0 & 0 \\
\hline FA & 24 & $220^{\circ} \mathrm{C}$ & 0 & 0 & 0 & 0 & 0 & 0 \\
\hline FA & 24 & $250^{\circ} \mathrm{C}$ & 0 & 0 & 0 & 0 & 0 & 0 \\
\hline FA & 24 & $300^{\circ} \mathrm{C}$ & 0 & 0 & 0 & 0 & 0,01 & 0 \\
\hline
\end{tabular}

Függelék 6. Táblázat. Fenolok koncentrációi (mg/l) a kísérletekben II. 


\begin{tabular}{|c|c|c|c|c|c|c|c|c|}
\hline 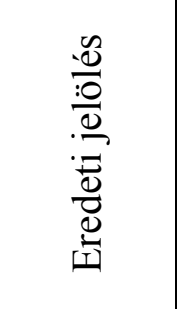 & 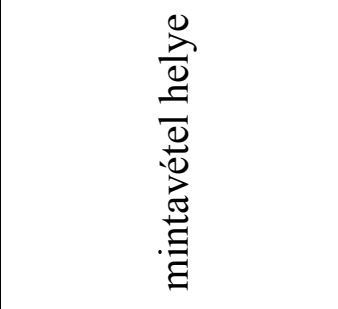 & $\begin{array}{l}\overline{0} \\
\text { N } \\
\bar{D}\end{array}$ & $\stackrel{\overline{0}}{\stackrel{0}{0}}$ & 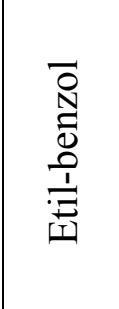 & 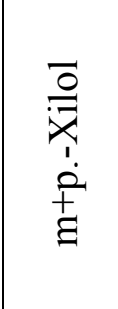 & $\begin{array}{l}\overline{0} \\
\overline{7} \\
1 \\
0\end{array}$ & $\begin{array}{l}\overline{0} \\
\stackrel{0}{N} \\
\text { N }\end{array}$ & 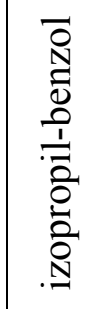 \\
\hline TMV004 & Lenti & 75,4 & 10,3 & 9,9 & 8,6 & 2,1 & 0,1 & 0,2 \\
\hline TMV005 & Babócsa & 78,2 & 0 & 5,8 & 0 & 1,7 & 0,1 & 0,5 \\
\hline TMV007 & Hajdúszoboszló & 0 & 0,1 & 0 & 0 & 0 & 0 & 0 \\
\hline TMV008 & Hajdúszoboszló & 250 & 27,2 & 4 & 0 & 3,3 & 0 & 0,1 \\
\hline TMV009 & Berekfürdő & 2,1 & 1,2 & 0,1 & 0,2 & 0,1 & 0 & 0 \\
\hline TMV010 & \begin{tabular}{|l} 
Földes K-29 \\
\end{tabular} & 200 & 12,1 & 0,8 & 0 & 0,4 & 0 & 0 \\
\hline TMV011 & Füzesgyarmat & 0,9 & 2,8 & 1,5 & 0 & 0,6 & 0 & 0,1 \\
\hline TMV012 & Eger & 3,9 & 0,5 & 0 & 0 & 0 & 0 & 0 \\
\hline TMV013 & Egerszalók & 1,8 & 0,9 & 0 & 0 & 0 & 0 & 0 \\
\hline TMV014 & Csengele & 3,1 & 1,1 & 0,2 & 0,2 & 0 & 0 & 0 \\
\hline TMV015 & Kiskunhalas & 0 & 0,6 & 0 & 0 & 0 & 0 & 0 \\
\hline TMV016 & Öcsöd & 29,6 & 33,6 & 6,4 & 14,3 & 7,2 & 0,5 & 0,2 \\
\hline TMV017 & Szolnok & 4,9 & 1,8 & 0,3 & 0,2 & 0,3 & 0 & 0,1 \\
\hline TMV019 & Nagybánhegyes & 181,7 & 158,4 & 152,6 & 400 & 90,7 & 5,4 & 1,2 \\
\hline TMV020 & Sarkad & 0 & 0 & 0,2 & 0,1 & 0,9 & 0,1 & 0 \\
\hline TMV021 & Deszk & 70,7 & 75,7 & 51,1 & 1,4 & 28 & 3,4 & 0,5 \\
\hline TMV022 & Zalaegerszeg & 5,8 & 2,5 & 0,7 & 1,2 & 0,3 & 0,1 & 0 \\
\hline TMV023 & Zalakaros & 174,8 & 51,3 & 1,5 & 5,7 & 4,6 & 0,5 & 0 \\
\hline TMV024 & Domaszék 5-159 & 650 & 49,8 & 22,3 & 42,8 & 15,8 & 0,2 & 0,2 \\
\hline TMV025 & Domaszék 5-43 & 250 & 58,9 & 63,8 & 75,9 & 50 & 1,3 & 0,9 \\
\hline TMV026 & Szeged & 65,9 & 13,3 & 16,4 & 19,9 & 29,4 & 0 & 0,2 \\
\hline TMV027 & Szeged & 0 & 0,3 & 0,2 & 1,5 & 0 & 0 & 0 \\
\hline TMV028 & \begin{tabular}{|l|} 
Szeged 5-94 \\
\end{tabular} & 138,7 & 55,8 & 25,5 & 40,3 & 21,4 & 0,6 & 0,4 \\
\hline TMV029 & Szeged, 5-209 & 550 & 70 & 36,4 & 55,6 & 26 & 0,6 & 0,4 \\
\hline TMV030 & Ásotthalom & 1150 & 122,7 & 124,9 & 112,4 & 50 & 20 & 47,9 \\
\hline TMV031 & Szolnok, 15-93 & 1300 & 124,7 & 172,4 & 137,3 & 50 & 17,3 & 7,1 \\
\hline TMV032 & Végegyháza & 48 & 48,7 & 38,6 & 113,4 & 20 & 0 & 0,5 \\
\hline TMV033 & Tótkomlós 3-105 & 27,2 & 14,9 & 9,7 & 13,9 & 5 & 0 & 0 \\
\hline TMV034 & Algyő 5-261 & 6,8 & 0 & 0 & 1 & 0 & 0 & 0 \\
\hline TMV035 & Algyö 5-262 & 12,3 & 0 & 0 & 1,6 & 0 & 0 & 0 \\
\hline TMV036 & Szarvas 3-263 & 48 & 68,7 & 37 & 61,2 & 24,6 & 0 & 0 \\
\hline TMV037 & Szarvas & 23,3 & 31,7 & 8 & 23,7 & 11,8 & 0 & 0 \\
\hline TMV038 & Gyula & 4,5 & 1,6 & 1,6 & 1,5 & 0,9 & 0 & 0 \\
\hline TMV039 & Gyula & 15,8 & 19,8 & 6,2 & 15,3 & 7,6 & 0 & 0 \\
\hline TMV040 & Orosháza & 46,7 & 40,5 & 15,3 & 28,9 & 14 & 0 & 0,3 \\
\hline TMV041 & Makó & 5,3 & 5,3 & 3,9 & 4,7 & 2,3 & 0 & 0 \\
\hline TMV042 & Hódmezővásárhely & 21,9 & 14 & 10,1 & 17,2 & 3,6 & 0 & 0 \\
\hline
\end{tabular}

Függelék 7. Táblázat. Benzol és alkilbenzolok koncentrációi $(\mu \mathrm{g} / 1)$ a hévizekben I. 


\begin{tabular}{|c|c|c|c|c|c|c|c|c|}
\hline 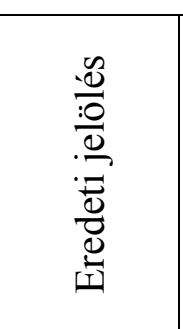 & 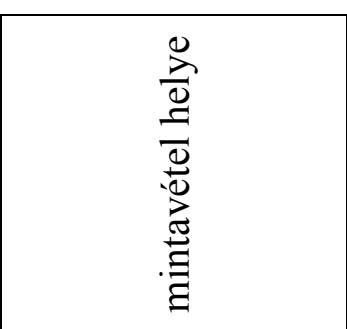 & 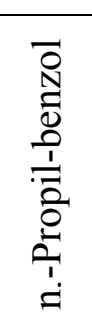 & 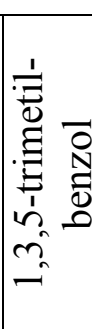 & 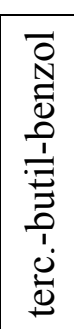 & 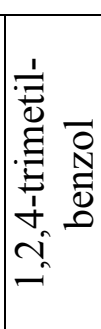 & 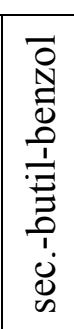 & 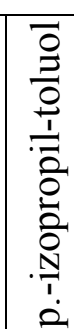 & 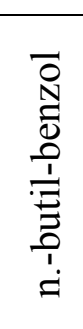 \\
\hline TMV004 & Lenti & 0,4 & 0,8 & 0 & 7,8 & 0,5 & 1,7 & 0 \\
\hline TMV005 & Babócsa & 0,2 & 1,2 & 0,2 & 2,5 & 0,3 & 0,3 & 0,3 \\
\hline TMV007 & Hajdúszoboszló & 0 & 0 & 0 & 0 & 0 & 0 & 0 \\
\hline TMV008 & Hajdúszoboszló & 0,1 & 0 & 0,9 & 0 & 0 & 0 & 0 \\
\hline TMV009 & Berekfürdő & 0 & 0 & 0 & 0,1 & 0 & 0 & 0 \\
\hline TMV010 & Földes K-29 & 0 & 0 & 0 & 0 & 0 & 0 & 0 \\
\hline TMV011 & Füzesgyarmat & 0,1 & 0 & 0,2 & 0 & 0 & 0,1 & 0 \\
\hline TMV012 & Eger & 0 & 0 & 0 & 0 & 0 & 0 & 0,1 \\
\hline TMV013 & Egerszalók & 0 & 0 & 0 & 0 & 0 & 0 & 0,1 \\
\hline TMV014 & Csengele & 0 & 0,1 & 0 & 0,1 & 0 & 0 & 0 \\
\hline TMV015 & Kiskunhalas & 0 & 0 & 0 & 0 & 0 & 0 & 0,2 \\
\hline TMV016 & Öcsöd & 0,1 & 0,6 & 0 & 4,3 & 0 & 0,6 & 0,5 \\
\hline TMV017 & Szolnok & 0 & 0 & 0,1 & 0,1 & 0 & 0,1 & 0,1 \\
\hline TMV019 & Nagybánhegyes & 0,9 & 2 & 0 & 80,7 & 0,1 & 2,7 & 0 \\
\hline TMV020 & Sarkad & 0 & 0,4 & 0 & 0,1 & 0 & 0,4 & 0 \\
\hline TMV021 & Deszk & 0,9 & 3,2 & 0 & 110 & 0,1 & 2,7 & 0 \\
\hline TMV022 & Zalaegerszeg & 0 & 0,1 & 0 & 0,8 & 0 & 0,1 & 0 \\
\hline TMV023 & Zalakaros & 0 & 0,2 & 0 & 1,1 & 0 & 0 & 0 \\
\hline TMV024 & Domaszék 5-159 & 0,2 & 1,8 & 0 & 20 & 0,1 & 0,6 & 2,1 \\
\hline TMV025 & Domaszék 5-43 & 2,9 & 7,9 & 0 & 20 & 0,5 & 8,2 & 2,8 \\
\hline TMV026 & Szeged & 0,5 & 16,2 & 0 & 21 & 0 & 0 & 0 \\
\hline TMV027 & Szeged & 0 & 0 & 0 & 0,9 & 0 & 0 & 0 \\
\hline TMV028 & Szeged 5-94 & 0,6 & 3,6 & 0 & 27 & 0 & 0,6 & 0,6 \\
\hline TMV029 & Szeged, 5-209 & 0,5 & 3,6 & 0 & 20 & 0,1 & 0,8 & 0,7 \\
\hline TMV030 & Ásotthalom & 20 & 20 & 0 & 20 & 5,8 & 6,5 & 10,8 \\
\hline TMV031 & Szolnok, 15-93 & 12,2 & 54,7 & 0 & 20 & 0,3 & 1,6 & 2,3 \\
\hline TMV032 & Végegyháza & 0,9 & 0 & 0 & 40,3 & 0 & 0,4 & 0,7 \\
\hline TMV033 & Tótkomlós 3-105 & 0 & 0 & 0 & 4,1 & 0 & 0 & 0 \\
\hline TMV034 & Algyő 5-261 & 0 & 0 & 0 & 1,4 & 0 & 0 & 0 \\
\hline TMV035 & Algyő 5-262 & 0 & 0 & 0 & 0,5 & 0 & 0 & 0 \\
\hline TMV036 & Szarvas 3-263 & 0,6 & 0 & 0 & 26,3 & 0 & 0,6 & 0 \\
\hline TMV037 & Szarvas & 0 & 0 & 0 & 3,2 & 0 & 0 & 0 \\
\hline TMV038 & Gyula & 0 & 0 & 0 & 1 & 0 & 0 & 0 \\
\hline TMV039 & Gyula & 0 & 0,2 & 0 & 2,8 & 0 & 0 & 0 \\
\hline TMV040 & Orosháza & 0,4 & 0 & 0 & 8,3 & 0 & 0,5 & 0 \\
\hline TMV041 & Makó & 0 & 0 & 0 & 5,2 & 0 & 0,7 & 0 \\
\hline TMV042 & Hódmezővásárhely & 0 & 0 & 0 & 14,3 & 0 & 0 & 0 \\
\hline
\end{tabular}

Függelék 8. Táblázat. Benzol és alkilbenzolok koncentrációi $(\mu \mathrm{g} / 1)$ a hévizekben II. 


\begin{tabular}{|c|c|c|c|c|c|c|c|c|c|}
\hline 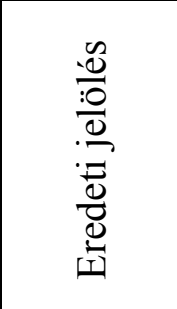 & 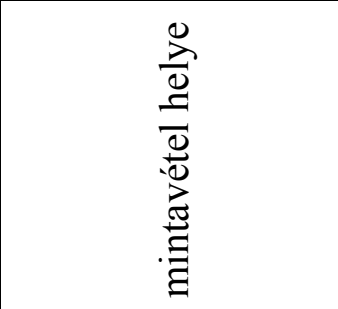 & 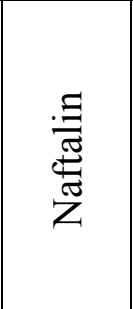 & 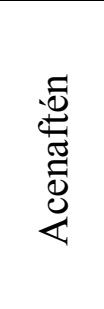 & 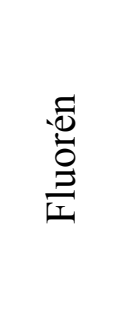 & 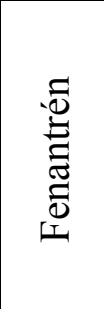 & 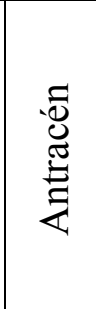 & 离 & 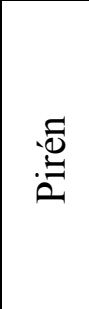 & 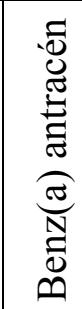 \\
\hline \begin{tabular}{|l|} 
TMV004 \\
\end{tabular} & Lenti & 392 & 298 & 194,2 & 1278 & 6,96 & 0 & 35 & 0 \\
\hline TMV005 & Babó & 149,6 & 163 & 312 & 692 & 0 & 190 & 4 & 0 \\
\hline TMV007 & Hajd & 77,8 & 49 & 94 & 332 & 12,1 & 30 & 10,2 & 0 \\
\hline TMV008 & Hajd & 17500 & 3140 & 4860 & 4100 & 52,6 & 352 & 138 & 0 \\
\hline TMV009 & Ber & 242 & 143 & 208 & 412 & 39,8 & 97,8 & 106 & 0 \\
\hline TMV010 & Főld & 1048 & 1272 & 2160 & 1430 & 50 & 220 & 60,2 & V \\
\hline TMV011 & Füze & 2060 & 2160 & 10360 & 3100 & 109 & 738 & 276 & 7,72 \\
\hline TMV012 & Ege & 33,6 & 11,8 & 71,2 & 60 & 0 & 14,4 & 6,4 & 0 \\
\hline TMV013 & Ege & 09,4 & 30,4 & 240 & 192 & 13,1 & 40,2 & 49,4 & 0 \\
\hline TMV014 & Cse & 68,4 & 56,6 & 128,6 & 152 & 25,6 & 52,8 & 12 & 0 \\
\hline TMV015 & & & 1204 & 1730 & 2860 & 56,6 & 850 & 270 & 0 \\
\hline TMV016 & Öcs & 7300 & 422 & 1824 & 2380 & 147 & 252 & 76 & 9,4 \\
\hline TMV017 & $\mathrm{Sz}$ & 1960 & 1336 & 886 & 406 & 34,4 & 300 & 100 & 3,8 \\
\hline & & & & & 3740 & 49,5 & 424 & 2,5 & 0 \\
\hline TMV020 & Sarl & 706 & 212 & 223 & 229 & 25,7 & 55,3 & 30,8 & 1,92 \\
\hline TMV021 & $\mathrm{De}$ & 8340 & 1570 & 4130 & 2010 & 74,2 & 190 & 45,3 & 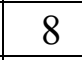 \\
\hline TMV & & & & & 0 & 0 & 11,7 & 4 & 2,29 \\
\hline TMV023 & Zala & 21700 & 83,8 & 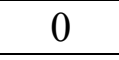 & 7570 & 0 & 155 & 213 & 0 \\
\hline TMV024 & Don & 12,91 & 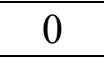 & 340 & 0 & 0 & 0 & 0 & 0 \\
\hline TMV025 & D & & 58,8 & & 0 & 238 & 0 & 50,2 & 11,6 \\
\hline TMV026 & & & 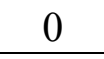 & & 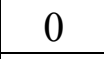 & & 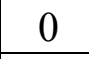 & 0 & 0 \\
\hline TMV027 & Szeg & 3600 & 760 & 468 & 1308 & 34,6 & 242 & 0 & 23 \\
\hline TMV028 & Szeg & 133,2 & 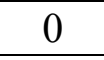 & 7,6 & 0 & 0 & 0 & 0 & 1,5 \\
\hline TMV029 & Szeg & 3674 & 97 & 584 & 1366 & 29,4 & 182 & 0 & 20,8 \\
\hline TMV030 & Ásot & 0 & 0 & 0 & 1004 & 764 & 322 & 0 & 41,6 \\
\hline TMV031 & Szoln & 336 & 690 & 324 & 804 & 37,6 & 81,4 & 0 & 31,8 \\
\hline TMV032 & & & 446 & & 0 & 0 & 0 & 0 & 0 \\
\hline TMV033 & Tótk & 24 & - & 0 & 748 & 162 & 610 & 29 & 5 \\
\hline TMV034 & Algyö 5-261 & 410 & 3,4 & 9,8 & 98 & 0 & 10,2 & 0 & 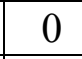 \\
\hline TMV035 & Algy & & & 144,6 & 1160 & 22,4 & 200 & 0 & 32 \\
\hline TMV036 & Szar & 6062 & 352 & 362 & 976 & 56 & 23,2 & 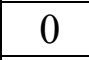 & 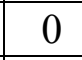 \\
\hline TMV037 & Szarvas & 2070 & 36,2 & 51,8 & 30,2 & 0 & 0 & 30,2 & 43,4 \\
\hline TMV038 & Gyula & 432 & 147 & 23,2 & 179 & 14 & 39,4 & 0 & 113 \\
\hline TMV039 & Gyula & 1962 & 0 & 34 & 276 & 0 & 0 & 58,4 & 12,9 \\
\hline TMV040 & Orosháza & 5334 & 104 & 434 & 2058 & 348 & 0 & 362 & 34 \\
\hline TMV041 & Makó & 4996 & 155 & 536 & 2024 & 674 & 98,8 & 368 & 58,8 \\
\hline TMV042 & Hódmezővásárhely & 2630 & 0 & 652 & 1381 & 46 & 17 & 0 & 0 \\
\hline
\end{tabular}

Függelék 9. Táblázat. PAH-ok koncentrációi $(\mu \mathrm{g} / 1)$ a hévizekben I. 


\begin{tabular}{|c|c|c|c|c|c|c|c|c|}
\hline 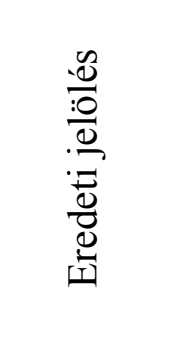 & 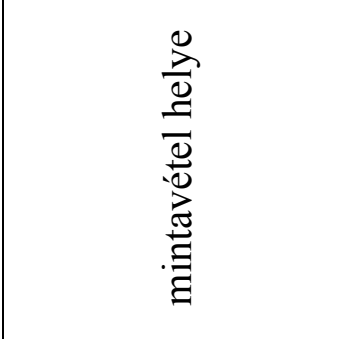 & : & 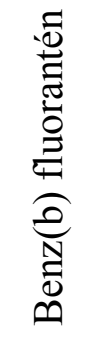 & 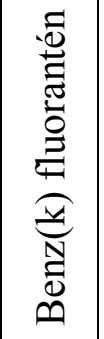 & 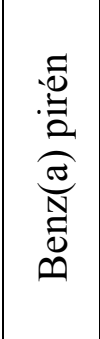 & 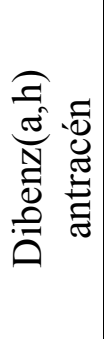 & 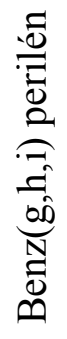 & 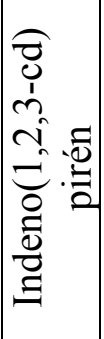 \\
\hline TMV004 & Lenti & 2,08 & 7,44 & 2,42 & 3,98 & 0 & 0 & 0 \\
\hline TMV005 & Babócsa & 2,76 & 2,5 & 0,2 & 0,26 & 0 & 0 & 0 \\
\hline TMV007 & Hajdúszoboszló & 11,8 & 1,74 & 0,48 & 0,94 & 0 & 0 & 0 \\
\hline TMV008 & Hajdúszoboszló & 0 & 0 & 0 & 0 & 0 & 0 & 0 \\
\hline TMV009 & Berekfürdő & 166 & 20,8 & 3,32 & 2,9 & 0 & 0 & 0 \\
\hline TMV010 & Földes K-29 & 46 & 2,56 & 0,3 & 0,5 & 0 & 0 & 0 \\
\hline TMV011 & Füzesgyarmat & 260 & 0 & 1,28 & 2,9 & 0 & 0 & 0 \\
\hline TMV012 & Eger & 0 & 0 & 0 & 0 & 0 & 0 & 0 \\
\hline TMV013 & Egerszalók & 0 & 0 & 0,34 & 0,66 & 0 & 0 & 0 \\
\hline TMV014 & Csengele & 11,2 & 4,08 & 0,26 & 0,42 & 0 & 0 & 0 \\
\hline TMV015 & Kiskunhalas & 0 & 22,8 & 1,42 & 2,38 & 0 & 0 & 0 \\
\hline TMV016 & Öcsöd & 49,8 & 5 & 0,2 & 1,2 & 0 & 0 & 0 \\
\hline TMV017 & Szolnok & 15 & 1,8 & 0,2 & 0 & 0 & 0 & 0 \\
\hline TMV019 & Nagybánhegyes & 0 & 9,24 & 0,48 & 0,56 & 0 & 0 & 0 \\
\hline TMV020 & Sarkad & 5,64 & 4,02 & 0,37 & 1,03 & 0 & 0 & 0 \\
\hline TMV021 & Deszk & 59,8 & 3,7 & 0,3 & 0,47 & 0 & 0 & 0 \\
\hline TMV022 & Zalaegerszeg & 4,44 & 0 & 0 & 0 & 0 & 0 & 0 \\
\hline TMV023 & Zalakaros & 0 & 8,1 & 0,47 & 1,08 & 0 & 0 & 0 \\
\hline TMV024 & Domaszék 5-159 & 0 & 0 & 0 & 0 & 0 & 0 & 0 \\
\hline TMV025 & Domaszék 5-43 & 11,4 & 0 & 0 & 0 & 0 & 0 & 0 \\
\hline TMV026 & Szeged & 0 & 0 & 0 & 0 & 0 & 0 & 0 \\
\hline TMV027 & Szeged & 19,5 & 0 & 0 & 0 & 0 & 0 & 0 \\
\hline TMV028 & Szeged 5-94 & 0 & 0 & 0 & 0 & 0 & 0 & 0 \\
\hline TMV029 & Szeged, 5-209 & 17,4 & 0 & 0 & 0 & 0 & 0 & 0 \\
\hline TMV030 & Ásotthalom & 0 & 0 & 0 & 0 & 0 & 0 & 0 \\
\hline TMV031 & Szolnok, 15-93 & 0 & 0 & 0 & 0 & 0 & 0 & 0 \\
\hline TMV032 & Végegyháza & 0 & 0 & 0 & 0 & 0 & 0 & 0 \\
\hline TMV033 & Tótkomlós 3-105 & 0 & 2,62 & 0 & 0 & 0 & 0 & 0 \\
\hline TMV034 & Algyö 5-261 & 0 & 0 & 0 & 0 & 0 & 0 & 0 \\
\hline TMV035 & Algyő 5-262 & 12,5 & 0 & 0 & 0 & 0 & 0 & 0 \\
\hline TMV036 & Szarvas 3-263 & 0 & 0 & 0 & 0 & 0 & 0 & 0 \\
\hline TMV037 & Szarvas & 0 & 6,84 & 0 & 0 & 0 & 0 & 0 \\
\hline TMV038 & Gyula & 6,32 & 0 & 0 & 0 & 0 & 0 & 0 \\
\hline TMV039 & Gyula & 13,7 & 0 & 0 & 0 & 0 & 0 & 0 \\
\hline TMV040 & Orosháza & 0 & 0 & 0 & 0 & 0 & 0 & 0 \\
\hline TMV041 & Makó & 0 & 0 & 0 & 0 & 0 & 0 & 0 \\
\hline TMV042 & Hódmezővásárhely & 2 & 0 & 0 & 0 & 0 & 0 & 0 \\
\hline
\end{tabular}

Függelék 10. Táblázat. PAH-ok koncentrációi $(\mu \mathrm{g} / \mathrm{l})$ a hévizekben II. 


\begin{tabular}{|c|c|c|c|c|c|c|c|c|c|}
\hline 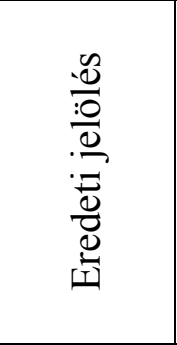 & 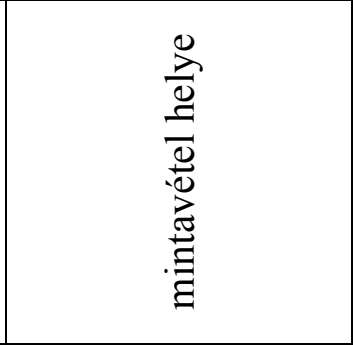 & 席 & 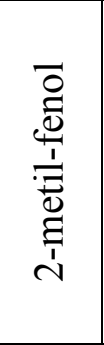 & 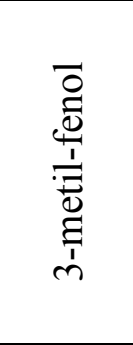 & 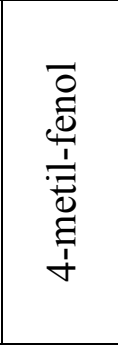 & 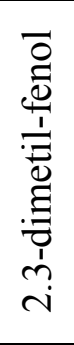 & 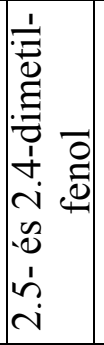 & 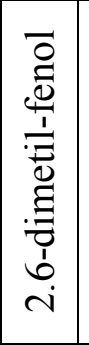 & 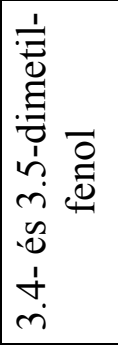 \\
\hline TMV004 & Lenti & 0 & 0 & 0 & 0 & 0 & 0 & 0 & 48 \\
\hline TMV005 & Babócsa & 0 & 0 & 0 & 0 & 0 & 0 & 0 & 0 \\
\hline TMV007 & Hajdúszoboszló & 0 & 0 & 0 & 0 & 0 & 0 & 0 & 0 \\
\hline TMV008 & Hajdúszoboszló & 0 & 0 & 0 & 10,6 & 0 & 10 & 0 & 32 \\
\hline TMV009 & Berekfürdő & 0 & 0 & 0 & 0 & 0 & 0 & 0 & 0 \\
\hline TMV010 & Földes K-29 & 0 & 0 & 8 & 0 & 0 & 0 & 0 & 0 \\
\hline TMV011 & Füzesgyarmat & 0 & 0 & 0 & 0 & 0 & 0 & 0 & 0 \\
\hline TMV012 & Eger & 0 & 0 & 0 & 0 & 0 & 0 & 0 & 0 \\
\hline TMV013 & Egerszalók & 0 & 0 & 0 & 0 & 0 & 0 & 0 & 0 \\
\hline TMV014 & Csengele & 0 & 5,2 & 18,6 & 14,7 & 0 & 0 & 0 & 0 \\
\hline TMV015 & Kiskunhalas & 0 & 0 & 0 & 0 & 0 & 0 & 0 & 0 \\
\hline TMV016 & Öcsöd & 1070 & 249 & 256,6 & 410 & 12 & 78 & 2,8 & 32 \\
\hline TMV017 & Szolnok & 0 & 0 & 0 & 0 & 0 & 0 & 0 & 0 \\
\hline TMV019 & Nagybánhegyes & 27,5 & 89,2 & 274,9 & 1,7 & 34 & 20 & 0 & 70 \\
\hline TMV020 & Sarkad & 0 & 0 & 0 & 0 & 0 & 0 & 0 & 0 \\
\hline TMV021 & Deszk & 1626 & 142 & 1073,4 & 848,4 & 39 & 232 & 7,7 & 204 \\
\hline TMV022 & Zalaegerszeg & 0 & 0 & 0 & 0 & 0 & 0 & 0 & 0 \\
\hline TMV023 & Zalakaros & 235,7 & 20,4 & 38,4 & 0 & 0 & 0 & 0 & 0 \\
\hline TMV024 & Domaszék 5-159 & 1218 & 314 & 754,6 & 657 & 39 & 227 & 27 & 153 \\
\hline TMV025 & Domaszék 5-43 & 343,3 & 33,4 & 315,4 & 159,4 & 13 & 32 & 0 & 52 \\
\hline TMV026 & Szeged & 79,5 & 3,3 & 0 & 8,6 & 0 & 0 & 0 & 4 \\
\hline TMV027 & Szeged & 0 & 0 & 0 & 0 & 0 & 0 & 0 & 0 \\
\hline TMV028 & Szeged 5-94 & 1538 & 228 & 88,7 & 488,7 & 46 & 252 & 10 & 174 \\
\hline TMV029 & Szeged, 5-209 & 0 & 110 & 0 & 0 & 46 & 158 & 7,8 & 133 \\
\hline TMV030 & Ásotthalom & 325,8 & 65,2 & 71,7 & 85,4 & 6,4 & 59 & 17 & 18 \\
\hline TMV031 & Szolnok, 15-93 & 0 & 0 & 0 & 0 & 0 & 7,3 & 0 & 3,1 \\
\hline TMV032 & Végegyháza & 1138 & 168 & 769,1 & 728,9 & 20 & 98 & 11 & 115 \\
\hline TMV033 & Tótkomlós 3-105 & 1211 & 266 & 365,5 & 661,8 & 16 & 210 & 19 & 63 \\
\hline TMV034 & Algyö 5-261 & 0 & 0 & 0 & 0 & 0 & 0 & 0 & 0 \\
\hline TMV035 & Algyö 5-262 & 0 & 0 & 0 & 0 & 0 & 0 & 0 & 0 \\
\hline TMV036 & Szarvas 3-263 & 2039 & 722 & 760,5 & 1360 & 31 & 356 & 19 & 134 \\
\hline TMV037 & Szarvas & 2454 & 1110 & 895 & 340,7 & 46 & 556 & 97 & 137 \\
\hline TMV038 & Gyula & 0 & 0 & 0 & 0 & 0 & 0 & 0 & 0 \\
\hline TMV039 & Gyula & 0 & 371 & 0 & 0 & 61 & 502 & 65 & 67 \\
\hline TMV040 & Orosháza & 1268 & 345 & 330,7 & 607,7 & 22 & 240 & 27 & 47 \\
\hline TMV041 & Makó & 0 & 0 & 0 & 0 & 0 & 0 & 0 & 3,6 \\
\hline TMV042 & Hódmezővásárhely & 11 & 0 & 0 & 0 & 0 & 0 & 0 & 0 \\
\hline
\end{tabular}

Függelék 11. Táblázat. Fenolok koncentrációi $(\mu \mathrm{g} / \mathrm{l})$ a hévizekben I. 


\begin{tabular}{|c|c|c|c|c|c|c|c|c|c|}
\hline 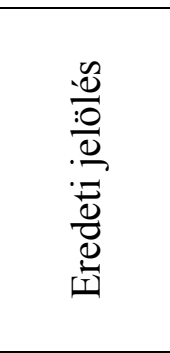 & 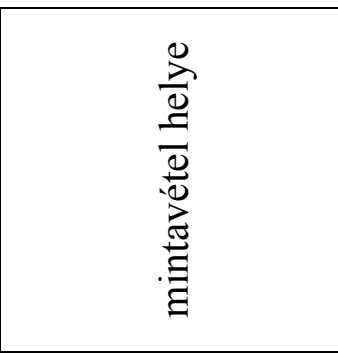 & 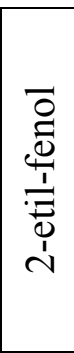 & $\begin{array}{l}\overline{0} \\
\frac{0}{0} \\
\stackrel{1}{1} \\
\overrightarrow{0} \\
\dot{0} \\
\dot{t}\end{array}$ & 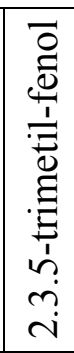 & 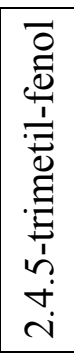 & 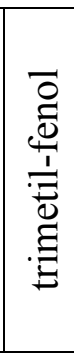 & 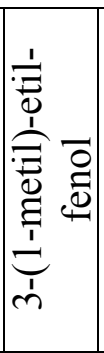 & 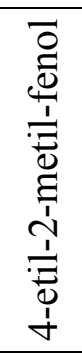 & 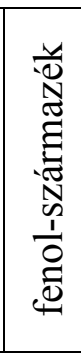 \\
\hline TMV004 & Lenti & 0 & 2,3 & 3,1 & 0 & 0 & 0 & 9,1 & 0 \\
\hline TMV005 & Babócsa & 0 & 0 & 0 & 0 & 0 & 0 & 0 & 0 \\
\hline TMV007 & Hajdúszoboszló & 0 & 0 & 0 & 0 & 0 & 0 & 0 & 0 \\
\hline TMV008 & Hajdúszoboszló & 0 & 21 & 2,1 & 0 & 0 & 0 & 11 & 0 \\
\hline TMV009 & Berekfürdő & 0 & 0 & 0 & 0 & 0 & 0 & 0 & 0 \\
\hline TMV010 & Földes K-29 & 0 & 4,9 & 0 & 0 & 0 & 0 & 0 & 0 \\
\hline TMV011 & Füzesgyarmat & 0 & 0 & 0 & 0 & 0 & 0 & 0 & 0 \\
\hline TMV012 & Eger & 0 & 0 & 0 & 0 & 0 & 0 & 0 & 0 \\
\hline TMV013 & Egerszalók & 0 & 0 & 0 & 0 & 0 & 0 & 0 & 0 \\
\hline TMV014 & Csengele & 0 & 0 & 0 & 0 & 0 & 0 & 0 & 0 \\
\hline TMV015 & Kiskunhalas & 0 & 0 & 0 & 0 & 0 & 0 & 0 & 0 \\
\hline TMV016 & Öcsöd & 5,6 & 21 & 4,9 & 4,1 & 8,1 & 0 & 11 & 12 \\
\hline TMV017 & \begin{tabular}{|l|} 
Szolnok \\
\end{tabular} & 0 & 0 & 0 & 0 & 0 & 0 & 0 & 0 \\
\hline TMV019 & Nagybánh & 22 & 191 & 0 & 0 & 0 & 12 & 50 & 107 \\
\hline TMV020 & Sarkad & 0 & 0 & 0 & 0 & 0 & 0 & 0 & 0 \\
\hline TMV021 & Deszk & 51 & 338 & 14 & 0 & 17 & 30 & 147 & 136 \\
\hline TMV022 & Zalaegersz & 0 & 0 & 0 & 0 & 0 & 0 & 0 & 0 \\
\hline TMV023 & Zalakaros & 0 & 0 & 0 & 0 & 0 & 0 & 0 & 0 \\
\hline TMV024 & zék 5-159 & 34 & 211 & 25 & 12 & 16 & 16 & 107 & 91 \\
\hline TMV025 & Domaszék 5-43 & 8,3 & 80 & 3,6 & 0 & 5,1 & 5,3 & 12 & 40 \\
\hline TMV026 & Szeged & 0 & 7,2 & 0 & 0 & 0 & 0 & 0 & 0 \\
\hline TMV027 & Szeged & 0 & 0 & 0 & 0 & 0 & 0 & 0 & 0 \\
\hline TMV028 & Szeged 5-94 & 47 & 242 & 18 & 0 & 14 & 21 & 145 & 110 \\
\hline TMV029 & Szeged, 5-209 & 43 & 308 & 1,7 & 0 & 5,3 & 28 & 147 & 119 \\
\hline TMV030 & Ásotthalom & 3,3 & 7,7 & 0 & 30 & 15 & 0 & 8 & 0 \\
\hline TMV031 & Szolnok, 15-93 & 0 & 4,4 & 3,7 & 0 & 0 & 0 & 0 & 3,2 \\
\hline TMV032 & Végegyháza & 15 & 94 & 9 & 3,6 & 5,7 & 3 & 50 & 3,7 \\
\hline TMV033 & Tótkomlós 3-105 & 14 & 49 & 18 & 33 & 29 & 1,8 & 35 & 5,6 \\
\hline TMV034 & Algyö 5-261 & 0 & 0 & 0 & 0 & 0 & 0 & 0 & 0 \\
\hline TMV035 & Algyö 5-262 & 0 & 0 & 0 & 0 & 0 & 0 & 0 & 0 \\
\hline TMV036 & Szarvas 3-263 & 19 & 43 & 23 & 30 & 34 & 3,1 & 34 & 4,3 \\
\hline TMV037 & Szarvas & 13 & 83 & 45 & 90 & 52 & 8 & 36 & 28 \\
\hline TMV038 & Gyula & 0 & 0 & 0 & 0 & 0 & 0 & 0 & 0 \\
\hline TMV039 & Gyula & 24 & 131 & 76 & 70 & 81 & 15 & 66 & 43 \\
\hline TMV040 & Orosháza & 12 & 49 & 10 & 46 & 34 & 0 & 30 & 6,5 \\
\hline TMV041 & Makó & 1,3 & 17 & 1,5 & 0 & 0 & 0 & 2,8 & 0 \\
\hline TMV042 & Hódmezővásárhely & 0 & 0 & 0 & 0 & 0 & 0 & 0 & 0 \\
\hline
\end{tabular}

Függelék 12. Táblázat. Fenolok koncentrációi $(\mu \mathrm{g} / \mathrm{l})$ a hévizekben II. 